Katharina Mader

\title{
Gender Budgeting: Ein emanzipatorisches, finanzpolitisches und demokratiepolitisches Instrument
}


Katharina Mader

\section{Gender Budgeting: Ein emanzipatorisches, finanzpolitisches und demokratiepolitisches Instrument}

In den letzen Jahren rückten vielfältige Gender Budgeting-Initiativen in den öffentlichen Fokus die das Ziel hatten, die Gleichstellung von Frauen und Männern $\mathrm{zu}$ fördern. Ihnen wird ein großes emanzipatorisches und demokratisches Potential zugeschrieben. Während der Demokratisierungsanspruch zwar häufig betont wird, stellen die Definition und Präzisierung von Demokratie bzw. Demokratisierung bislang weitgehend unbehandelte Bereiche dar. Daher zielt die Arbeit darauf ab, die theoretische Fundierung von Gender Budgeting zu vertiefen und damit einen Beitrag zu einer geschlechtergerechten und emanzipatorischen Demokratisierung der Finanzpolitik zu leisten. Mit Hilfe einer Qualitativen Inhaltsanalyse wird eine Untersuchung feministisch-demokratietheoretischer Überlegungen vorgenommen, um daraus einen Kriterienkatalog zu entwickeln. Dieser wird anschließend in den Budgetprozess integriert, um ein Modell eines feministisch-demokratischen Budgetprozesses beispielhaft anhand des Wiener Budgetkreislaufes zu entwerfen.

Katharina Mader ist Projektmitarbeiterin und Lektorin am Institut für Institutionelle und Heterodoxe Ökonomie der Wirtschaftsuniversität Wien. 
Gender Budgeting: Ein emanzipatorisches, finanzpolitisches und demokratiepolitisches Instrument 


\section{Forschungsergebnisse der Wirtschaftsuniversität Wien}

\section{Band 31}

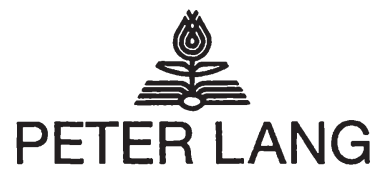

Frankfurt am Main · Berlin · Bern · Bruxelles - New York · Oxford · Wien 
Katharina Mader

\section{Gender Budgeting: Ein emanzipatorisches, finanzpolitisches und demokratiepolitisches Instrument \\ Theoretische Fundierung und Exemplifizierung am Wiener Budgetprozess}

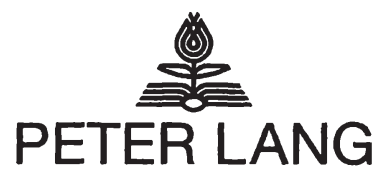

Internationaler Verlag der Wissenschaften 


\section{Bibliografische Information der Deutschen Nationalbibliothek}

Die Deutsche Nationalbibliothek verzeichnet diese Publikation in der Deutschen Nationalbibliografie; detaillierte bibliografische Daten sind im Internet über <http://www.d-nb.de> abrufbar.

Open Access: The online version of this publication is published on www.peterlang.com and www.econstor.eu under the international Creative Commons License CC-BY 4.0. Learn more on how you can use and share this work: http://creativecommons.org/licenses/ by/4.0.

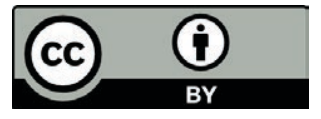

This book is available Open Access thanks to the kind support of ZBW - Leibniz-Informationszentrum Wirtschaft.

Umschlaggestaltung:

Atelier Platen, nach einem Entwurf der

Werbeagentur Publique.

Universitätslogo der Wirtschaftsuniversität Wien:

Abdruck mit freundlicher Genehmigung der Wirtschaftsuniversität Wien.

Gefördert durch die Wirtschaftsuniversität Wien.

Gedruckt auf alterungsbeständigem, säurefreiem Papier.

ISSN 1613-3056

ISBN 978-3-631-59153-6

ISBN 978-3-631-75378-1 (eBook)

(c) Peter Lang GmbH

Internationaler Verlag der Wissenschaften

Frankfurt am Main 2009

Alle Rechte vorbehalten.

Das Werk einschließlich aller seiner Teile ist urheberrechtlich geschützt. Jede Verwertung außerhalb der engen Grenzen des

Urheberrechtsgesetzes ist ohne Zustimmung des Verlages

unzulässig und strafbar. Das gilt insbesondere für

Vervielfältigungen, Übersetzungen, Mikroverfilmungen und die Einspeicherung und Verarbeitung in elektronischen Systemen.

Printed in Germany 123457

www.peterlang.de 


\begin{abstract}
All jenen, die über die Zeit so maßgeblich zum Gelingen des vorliegenden Dissertationsprojektes und Buches beigetragen haben, sei hiermit auf das Allerherzlichste gedankt
\end{abstract}


Katharina Mader - 978-3-631-75378-1

Downloaded from PubFactory at 01/11/2019 05:43:12AM

via free access 


\section{Inhaltsverzeichnis}

Abbildungs- und Tabellenverzeichnis .................................................................11

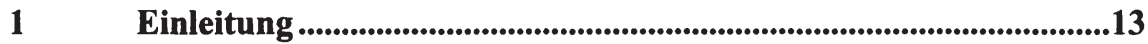

2 Begriffsklärungen und -abgrenzungen ...............................................17

2.1 Gender Budgeting .............................................................................. 17

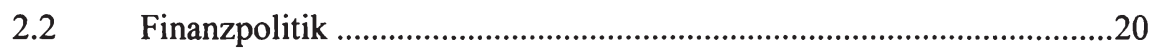

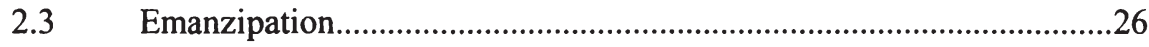

2.4 Demokratie und Demokratisierung..................................................27

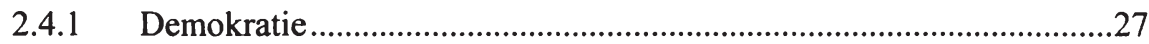

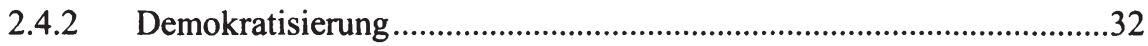

3 Budgets und die Forderung nach Demokratisierung der Finanzund Wirtschaftspolitik .............................................................................35

3.1 Fallbeispiel Budgetinitiative zur Demokratisierung der Wirtschaftspolitik: PB - Participatory Budgeting.....................................................41

3.1.1 Hintergrund und Entstehungszusammenhang des Partizipativen

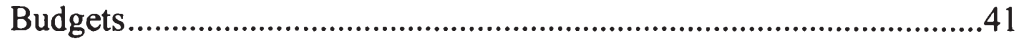

3.1.2 Definition, Funktionsweisen und Zielsetzungen des Partizipativen Budgets.

3.1.3 Standortbestimmung Partizipatives Budget und Demokratisierung der Wirtschaftspolitik

3.1.3.1 Input: Mitbestimmung und Beteiligung.............................................47

3.1.3.1.1 Sozioökonomisches Profil der Teilnehmenden .............................48

3.1.3.1.2 Geschlechtsspezifisches Profil der Teilnehmenden........................52

3.1.3.2 Institutionen: Kombination direkter und repräsentativer Demo-

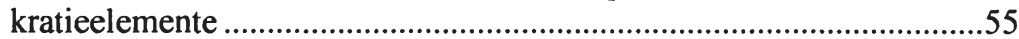

3.1.3.3 Output: Verteilungsgerechtigkeit ........................................................58

3.2 Gender Budgeting und eine Demokratisierung der Finanz- und Wirtschaftspolitik.

3.2.1 Hintergrund und Entstehungszusammenhang des Gender Bud-

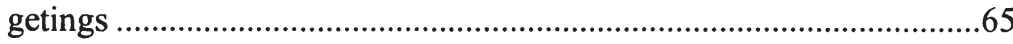

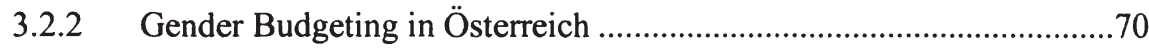


3.2.2.1 Standortbestimmung der Demokratisierungspotentiale - Gender

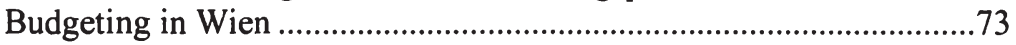

3.2.2.1.1 Input Mitbestimmung und Beteiligung............................................74

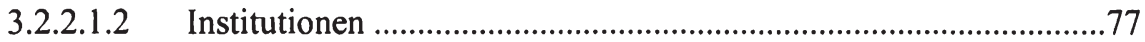

3.2.2.1.3 Output: Geschlechter- und Verteilungsgerechtigkeit .....................79

3.2.3 Zwischenfazit: Gender Budgeting zugunsten des Partizipativen Budget aufgeben?

3.2.4 Welche demokratietheoretischen Grundlagen braucht Gender Budgeting?

4 Demokratieverständnis und -konzept für Gender Budgeting: Ein Kriterienkatalog feministischer Demokratietheorien . 87

4.1 Methodische Vorgangsweise: Eine Qualitative Inhaltsanalyse ...........87

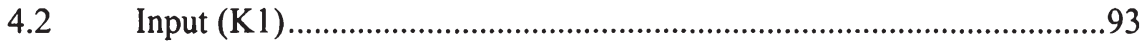

4.2.1 Anerkennung von Geschlechterdifferenz ..........................................93

4.2.2 Partizipation von Frauen ...................................................................96

4.2.3 Aktive Staatsbürgerinnenschaft von Frauen .....................................100

4.2.4 Zivilgesellschaft und die Beteiligung von NGOs ................................105

4.2.5 Partizipatorische Parität .........................................................................109

4.3 Institutionen und Prozesse (K2) ...................................................110

4.3.1 Öffentlichkeit und Deliberation ........................................................110

4.3.2 Quantitative politische Repräsentation von Frauen in politischen Verfahren und Institutionen (Soziale Repräsentation).........................116

4.3.3 Funktionale bzw. Gruppenrepräsentation: die Repräsentation der Interessen und Bedürfnisse von Frauen im Politikprozess

4.3.4 Repräsentation und Anerkennung von Unterschieden zwischen Frauen sowie Berücksichtigung von Differenzen aufgrund von Alter, Klasse, Ethnie, Religion, Sexualität

4.3.5 Political Leadership und Empowerment - Entscheidungs- und Definitionsmacht für Frauen ................................................................130

4.3.6 Responsivität politischer Institutionen................................................131

4.3.7 Transparenz von Politikprozessen ................................................133

4.3.8 Kontrolle - Rechenschaftspflicht - Accountability ...........................134

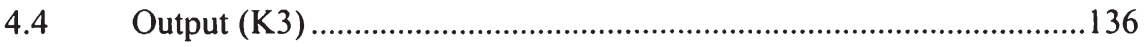


4.4.1 Frauenfreundlicher Output von Politik: geschlechtergerechte Umverteilung von Ressourcen (Geld und Macht).

4.5 Zwischenfazit: Kriterienkatalog feministischer Demokratietheorien.139

5 Integration feministischer Demokratiekriterien in den Wiener Budgetprozess.

5.1 Der Budgetprozess als Kreislauf..................................................143

5.2 Der Wiener Budgetprozess und -kreislauf.........................................145

5.2.1 Erstellung des Voranschlagsentwurfes ..............................................147

5.2.2 Feststellung (Genehmigung) des Voranschlages ...............................147

5.2.3 Vollziehung des Voranschlages ...........................................................148

5.2.4 Gebarungskontrolle ...........................................................................148

5.3 Feministisch-demokratietheoretische Erweiterung des Wiener Budgetkreislaufes

5.3.1 Generelle feministisch-demokratische Bedingungen für den Wiener Budgetkreislauf

5.3.2 Institutionelle feministisch-demokratische Bedingungen in den Phasen der Erstellung und der Feststellung des Voranschlages ........156

5.3.3 Institutionelle und outputorientierte feministisch-demokratische Bedingungen für die Phase der Vollziehung des Voranschlages .......161

5.3.4 Institutionelle feministisch-demokratische Bedingung in der Phase

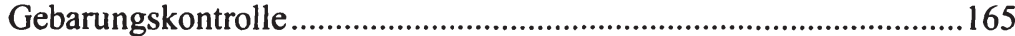

$6 \quad$ Fazit und weiterer Forschungsbedarf............................................169

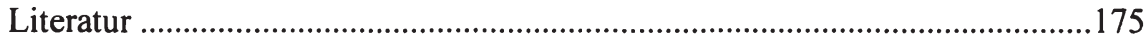


Katharina Mader - 978-3-631-75378-1

Downloaded from PubFactory at 01/11/2019 05:43:12AM

via free access 


\section{Abbildungs- und Tabellenverzeichnis}

Abbildung 1: Schematische Darstellung des partizipativen Budgetprozesses

Abbildung 2: Anzahl der Beteiligten am Partizipativen Budget in Porto

Alegre 1990-2003

Abbildung 3: Beteiligung an den einzelnen Institutionen des Partizipativen

Budget in Porto Alegre nach dem Familieneinkommen der Teilnehmenden, 2002

Abbildung 4: Beteiligung an den einzelnen Institutionen des Partizipativen Budget in Porto Alegre nach der Schulbildung der Teilnehmenden, 2002

Abbildung 5: Beteiligung am Partizipativen Budget in Porto Alegre 1995, 1998 und 2000 nach Geschlecht der Teilnehmenden.

Abbildung 6: Beteiligung an den einzelnen Institutionen des Partizipativen Budget in Porto Alegre nach dem Geschlecht der Teilnehmenden, 2002

Abbildung 7: Allgemeines Ablaufmodell der Strukturierenden Inhaltsanalyse

Abbildung 8: Ablaufmodell der Inhaltlichen Strukturierung

Abbildung 9: Phasen des Budgetkreislaufes

Abbildung 10: Adaptierter Budgetkreislauf für Wien

Abbildung 11: Wiener Budgetkreislauf erweitert um feministisch-demokratietheoretische Kriterien

Abbildung 12: Generelle bzw. Inputkriterien für den gesamten Budgetkreislauf

Abbildung 13: Institutionelle bzw. prozessuale Kriterien für die Phasen Erstellung und Feststellung des Voranschlages

Abbildung 14: Prinzipien für die Phase des Voranschlagvollzuges.

Abbildung 15: Kriterienkomplex der Kontrolle für die Phase Gebarungskontrolle.

Tabelle 1: Sprechen während der Sitzungen des partizipativen Budgets in

Porto Alegre.

Tabelle 2: Kodierleitfaden

Tabelle 3: Überblick Kriterienkatalog feministischer Demokratietheorien. 
Katharina Mader - 978-3-631-75378-1

Downloaded from PubFactory at 01/11/2019 05:43:12AM

via free access 


\section{Einleitung}

In den letzen Jahren avancierten in Europa sowie in Österreich vielfältige Gender Budgeting-Initiativen ${ }^{1}$ mit dem Ziel, die Gleichstellung von Frauen und Männern, anhand einer inhaltlichen geschlechtergerechten Revision der Finanzpolitik sowie deren institutionellen und prozessualen Öffnung und Demokratisierung, zu fördern. Ihnen wird ein großes emanzipatorisches (Veränderungs-) Potential zugeschrieben. So besteht mit der Forderung nach Gender Budget-Initiativen ein breiter Konsens über ein damit verbundenes Anliegen, Budgets und die Finanzpolitik im Allgemeinen partizipativer und transparenter zu gestalten sowie tief greifende politische Veränderungsprozesse hin zu mehr Geschlechtergerechtigkeit in Gang zu setzen. Mit diesem Demokratisierungsanspruch ist jedoch eine Diskrepanz in zweierlei Hinsicht verbunden: Erstens ist zwischen dem partizipativen Anspruch von Gender Budgeting per definitionem und der Umsetzung von Gender Budget-Initiativen in der Praxis eine gewisse Kluft festzustellen. Und zweitens wird in der wissenschaftlichen Auseinandersetzung um das Thema Gender Budgeting die Forderung nach Demokratisierung der Finanzpolitik zwar häufig betont. Wie Demokratie beziehungsweise Demokratisierung jedoch im diesem Zusammenhang präzisiert, definiert und theoretisch fundiert werden soll, stellt bislang einen weitgehend unbehandelten Bereich im wissenschaftlichen Diskurs dar. Hierbei wirkt die fehlende theoretische Basis und Präzisierung eines Demokratieverständnisses für Gender Budgeting wiederum auf die Gestaltung der demokratischen Praxis von Gender Budget-Inititativen.

Mein Vorhaben ist es daher, mit dieser Dissertation die theoretische Fundierung der Praxis von Gender Budgeting zu vertiefen und damit Grundlagen zu schaffen um das Potential von Gender Budgeting als Beitrag zu einer geschlechtergerechten und emanzipatorischen Demokratisierung der Finanzpolitik zu stärken. Den Ausgangspunkt hierfür bildet die forschungsleitende Fragestellung: Welches Demokratiekonzept beziehungsweise welches Demokratieverständnis und welche demokratietheoretischen Grundlagen müssen Gender Budgeting zugrunde gelegt werden damit es ein emanzipatorisches, finanz- und wirtschaftspolitisches Instrument sein kann?

1 In der Gender Budgeting-Literatur bezeichnet der Term Gender Budgeting-Initiative kontextabhängig zweierlei: Erstens werden Initiativen als (zivilgesellschaftliche) Gruppierungen, Organisationen oder Arbeitskreise verstanden, deren Ziel es ist einen Anstoß zu Gender Budgets zu geben, Gender Budgeting bekannt zu machen und die die politische Debatte einzubringen (siehe dazu Kapitel 3.2.1). Zweitens umfasst der Begriff der Initiative auch die konkrete Umsetzung von Gender Budgeting beziehungsweise konkrete Aktivitäten und Projekte zu Gender Budgeting, wie beispielsweise in Wien (vgl. Kapitel 3.2.2). 
Hierbei kann es nicht den einen ,richtigen“ Ansatz geben, denn Gender Budgeting-Initiativen unterscheiden sich vielschichtig je nach ihren spezifischen sozialen und politischen Kontexten und weisen vielfältige Facetten auf, je nachd der unterschiedlichen Art der Institutionen, welche die Implementierung von Gender Budgeting forcieren. Daher werde ich vielmehr eine normative Alternative zum derzeit vorherrschenden Modell der Finanzpolitik und des Budgetprozesses aufzeigen und eine Strategie zur Vertiefung der feministisch-demokratischen und emanzipatorischen Praxis entwerfen.

Meiner Dissertation liegen im Folgenden qualitative Forschungsmethoden, die „auf die Analyse komplexer Deutungs- und Wahrnehmungssysteme ausgerichtet“ sind um ,objektive Strukturzusammenhänge auf[zu]decken [und] um eine möglichst umfassende Analyse von individuellen (und kollektiven) Handlungskontexten leisten zu können" (Hopf, 1979 zit. in Becker-Schmidt/Bilden 1991: 25). Für feministische Forschungen haben qualitative Untersuchungsansätze gerade deshalb und „weil weibliche Realität als gesellschaftliches und individuelles Phänomen besonders explorationsbedürftig ist" (Becker-Schmidt/ Bilden 1991: 24) einen hohen Stellenwert bekommen.

Ich bevorzuge in meiner Dissertation auch deshalb qualitative Methoden, weil auf dem vorliegenden Gebiet noch vergleichsweise wenig geforscht wurde und es so „nur konsequent [ist], wenn (...) Untersuchungen zunächst einmal zum Zweck der Generierung von Hypothesen und der Theoriekonstruktion" (Krüger 1994: 78, Hervorhebung im Original) durchgeführt werden. Qualitatives Forschen ist in der feministischen Forschung ,unverzichtbar, da es gerade um die Aufdeckung noch unsichtbarer Strukturen und die Analyse höchst komplexer Deutungsmuster neuen Inhalts geht" (Sturm 1994: 94). „Theoriegeleitete qualitative (...) Forschung impliziert also Androzentrismuskritik" (Becker-Schmidt/ Bilden 1991: 23). Feministische Forschung und Wissenschaft bedeutet im $\mathrm{Zu}$ sammenhang mit der vorliegenden Dissertation außerdem die Überwindung eines wissenschaftlichen Androzentrismus in der Wirtschafts- und Politikwissenschaft sowie die Kritik und Überwindung eines politischen Maskulinismus in der Wirtschafts- und Finanzpolitik.

Da die feministische Politikwissenschaft über eine umfassende Auseinandersetzung mit Demokratie, Demokratisierung und demokratischen Modellen sowie deren Chancen und Problemen hinsichtlich der Partizipation von Frauen verfügt, habe ich meine Forschungsarbeit an dieser Dissertation inter- sowie transdisziplinär angelegt sowie versucht, die disziplinären Grenzen der Wirtschaftswissenschaft zu überwinden und dadurch Erkenntnisse zu gewinnen, die nicht mehr nur einer einzigen Disziplin zu zuordnen sind.

Hinsichtlich des Aufbaus meiner Dissertation soll Kapitel 2 zunächst der Begriffsklärung und -definition sowie der Abgrenzung des Untersuchungsgegenstandes dienen. Ich werde die meiner Dissertation zugrunde liegenden und als 
ihre Ausgangspunkte dienenden wesentlichen Begrifflichkeiten Gender Budgeting, Finanzpolitik, Emanzipation ebenso wie Demokratie und Demokratisierung klären und erklären.

Danach werde ich in Kapitel 3 die theoretischen und politischen Grundlagen der Forderung nach einer Demokratisierung von Finanz- und Wirtschaftspolitik behandeln. In einer Reihe von Ländern haben sich in den vergangenen Jahrzehnten Budget-Initiativen mit dem Ziel eine Demokratisierung der Wirtschaftspolitik zu forcieren entwickelt. Exemplarisch werde ich daher in einem nächsten Schritt anhand des Fallbeispiels „Participatory Budgeting in Porto Algere“ (Kapitel 3.1) einen der vielen Ansätze und Erfahrungen, wie Demokratisierung von Wirtschaftspolitik erwirkt werden könnte, darstellen. Im Anschluss daran werde ich die mit Gender Budgeting verbundene Forderung nach einer Demokratisierung der Finanz- und Wirtschaftspolitik genauer erörtern (Kapitel 3.2) sowie anhand einer Darstellung von Gender Budgetings in Österreich (Kapitel 3.2.2) -im Speziellen von Gender Budgeting in Wien - eine Standortbestimmung der Demokratisierungspotentiale von Gender Budgeting vornehmen. Abschließend werde ich außerdem herausarbeiten, warum die Idee des Gender Budgetings nicht zugunsten eines Partizipativen Budgets nach dem Vorbild Porto Alegres aufgegeben werden sollte (Kapitel 3.2.3).

In Kapitel 4 werde ich mich dann mit der Erarbeitung der theoretischen Fundierung und Präzisierung eines Demokratiekonzeptes un'd -verständnisses für Gender Budgeting befassen. Ziel ist eine systematische Untersuchung der zentralen Begrifflichkeiten und Konzepte des feministischen demokratietheoretischen Diskurses ebenso wie der Arbeiten und Ansätze ausgewählter feministischer Demokratietheoretikerinnen. Diese Untersuchung werde ich mit Hilfe einer Qualitativen Inhaltsanalyse beziehungsweise mit Hilfe der spezifischen Form der Strukturierenden Inhaltsanalyse mit inhaltlicher Vorgehensweise vornehmen. Forschungsleitend ist hierbei die Frage nach der theoretischen Präzisierung beziehungsweise Fundierung eines Demokratieverständnisses für Gender Budgeting.

Da feministische Wissenschaft sowohl erkenntnis- als auch handlungsorientiert ist, werde ich aus den gewonnenen theoretischen Erkenntnissen in Kapitel 5 inhaltliche und prozessbezogene Konsequenzen für eine geschlechtergerechte Finanz- und Wirtschaftspolitik ableiten. Dementsprechend werde ich versuchen, den in Kapitel 4.5 dargestellten Katalog feministisch-demokratischer Kriterien in den Budgetprozess zu integrieren und damit einen systemimmanenten Vorschlag zu einer geschlechtergerechten und emanzipatorischen Demokratisierung von Budgetprozessen zu machen sowie ein Modell für die Gestaltung und Organisation eines feministisch-demokratischen Budgetprozesses beispielhaft anhand des Wiener Budgetkreislaufes zu entwerfen. 
Abschließend werde ich in Kapitel 6 die Erkenntnisse und Analysen der vorangegangen Kapitel als Schlussfolgerungen zusammenführen, bevor ich resümierend ein Fazit ziehe und einen Ausblick auf weitere mögliche Forschungsaufgaben gebe. 


\section{Begriffsklärungen und -abgrenzungen}

Begriffe sind „wortgeronnene Erfahrungen der Wissenschaftler[Innen], sie sind Mittel der Konstruktion wissenschaftlicher Erkenntnis" (Kreisky/Sauer 1997: 22), sie definieren den Bestand an Untersuchungsgegenständen und haben eine ordnende Bedeutung, $\mathrm{x}$ indem sie die Art der aus ihnen ausbaubaren Aussagen festlegen (vgl. ebd.). Begriffsinhalte werden über Definitionen festgelegt, diese können als ,jede Art der Feststellung oder Festssetzung des Gebrauchs eines sprachlichen Ausdrucks“ (Nohlen 1995: 68 zit. in Kreisky/Sauer 1997: 23) bezeichnet werden. Definitionen sollen praktikable Verwendungsweisen von Begriffen bereitstellen und sind somit Übereinkünfte über deren Gebrauch (vgl. Kreisky/Sauer 1997: 23).

Die meiner Dissertation zugrunde liegenden und als ihre Ausgangspunkte dienenden wesentlichen Begrifflichkeiten möchte ich daher im Folgenden klären und definieren, also „[b]enennen durch Abgrenzen“ (ebd.: 24).

\subsection{Gender Budgeting}

Bis heute haben sich Schätzungen zufolge seit der ersten Gender ${ }^{2}$ Budget-Initiative in Australien im Jahr 1983 weit über 60 Initiativen in allen Teilen der Welt entwickelt (vgl. Sharp 2007: 2). Diese entstanden im Kontext nationaler und internationaler feministischer Bewegungen, der wissenschaftlich-theoretischen Auseinandersetzung gingen praktische Erfahrungen voraus, ihre theoretische Fundierung kam von unten und wurde aus der frauenbewegten Praxis hergeleitet (vgl. Sharp/Broomhill 2002: 42).

2 Gender wird gemäß dem gendertheoretischen Theoriestrang als das soziale Geschlecht im Unterscheid zum biologischen Geschlecht (,Sex') verstanden. „Gender is the social meaning given to biological differences between the sexes; it refers to cultural constructs rather than to biological givens" (Ferber/Nelson 1993: 9f). Die Unterscheidung zwischen biologischem und sozialem Geschlecht impliziert, dass das soziale Geschlecht ein kulturelles, historisches, gesellschaftliches und ideologische Konstrukt ist: „Gender relations are social constructions (social forces and historical structures) that differentiate and circumscribe material outcomes for women and men" (Bakker 1994: 3). Gender repräsentiert „einen durch geschlechtsspezifische Zuweisungen erworbenen Status“ (BEIGEWUM 2002: 59) und ist ein historisch gewachsenes soziales Konstrukt. „Mit dem ,sozialen Geschlecht' sind Erwartungen, Eigenschaften, Rollenbilder, Handlungsmuster etc. gemeint" (ebd.: 13), die Frauen und Männern aufgrund von gesellschaftlichen Prozessen zugeschrieben werden. Der Begriff Gender wendet sich gegen einen biologischen Determinismus „der Naturalisierung von Geschlechterdifferenzen. Mit der Trennung von ,natürlichen' und ,künstlichen' Komponenten von Geschlecht werden bestehende Geschlechterhierarchien der Kritik zugänglich gemacht und neue gesellschaftliche Arrangements der Geschlechter eröffnet“" (ebd.: 59f). 
Gender Budgets ,provide a means for determining the effect of government revenue and expenditure policies on women and men" (Budlender et al 2002: 52). Diese können aus verschiedenen Komponenten bestehen und unterscheiden sich je nach Land oder Region aufgrund deren spezifisch sozialen und politischen Kontexte sowie aufgrund der unterschiedlichen Arten der Institutionen, die eine Gender Budget-Implementierung forcieren. Resultat dessen ist, dass es kein einheitliches Verständnis von Gender Budgeting gibt ${ }^{3}$ und sich je nach dem jeweiligen Kontext eine „breite Palette, sowohl hinsichtlich der AkteurInnen, inhaltlichen Reichweite, zeitlichen Ausrichtung als auch hinsichtlich der verwendeten Methoden und Zugänge" (Klatzer 2003: 31) zeigt.

Sowohl die Praxis als auch die Theorie des Gender Budgeting stellen heute differente, kontextabhängige sowie schnell wachsende Bereiche dar, Arbeiten dazu reichen von der Entwicklung neuer kontextueller Rahmen, Methoden und Indikatoren bis zu Länderstudien und Trainingshandbüchern (vgl. Sharp 2007: 2).

Die theoretischen Forschungsarbeiten zu Gender Budgeting sind multidisziplinär mit Beiträgen aus der Finanzwissenschaft, der feministischen Ökonomie, der Entwicklungsökonomie ebenso wie aus der Verwaltungslehre, der Soziologie und der Politikwissenschaft, wobei ,an overarching research agenda to underpin gender responsive budgeting is yet to be mapped out" (Sharp 2007: 7). Gerade für die Entwicklung von Visionen ist "die Zusammenarbeit verschiedener Disziplinen und feministischer Zugänge wichtig, ein Zusammenspiel von PraktikerInnen und TheoretikerInnen mit unterschiedlichsten ökonomischen, politikwissenschaftlichen, historischen, soziologischen und theoriegeschichtlichen Hintergründen" (BEIGEWUM 2002: 201). Mit fortschreitender Entwicklung und Differenzierung der theoretischen Arbeiten werden dadurch jedenfalls die Herausforderungen für Gender Budgeting und die zugehörige Forschungsarbeit ,larger rather than smaller“ (Sharp/Broomhill 2002: 43).

Der gemeinsame Ausgangspunkt verschiedener Gender Budget-Initiativen ist grundsätzlich die Annahme, dass Budgets zwar ,formal gesehen eine Gegenüberstellung von Einnahmen und Ausgaben [sind]. Die Ausgestaltung und Wirkung dieser Einnahmen und Ausgaben ist allerdings alles andere als ,geschlechtsneutral'“ (Angelo et al 2003: 29). Vielmehr reflektieren sie die ökonomischen, sozialen und gesellschaftlichen Prioritäten eines Staates und spiegeln so die Werte einer Gesellschaft und ein „bestimmtes gesellschaftspolitisches Leitbild“ (BEIGEWUM 2002: 12) wider. Das Budget ist Resultat politischer Entscheidungen darüber, wie beziehungsweise von wem die Einnahmen erhoben

3 Dementsprechend finden sich international auch als Resultat der vielfältigen Wurzeln und Entstehungszusammenhänge oftmals folgende Begriffe: Women's Budgets, Gender-Responsive Budgeting, Gender-Sensitive Budgeting oder im deutschen Sprachgebrauch auch Geschlechtergerechte Budgetgestaltung. 
und für welche Zwecke also für wen die Ausgaben getätigt werden und bilden so die Machtverhältnisse in der Gesellschaft ab: „The budget reflects the values of a country - who it values, whose work it values and who it rewards... and who and what and whose work it doesn't" (Budlender 1996 zit. in Elson 1999: 11). Im Zuge dessen spiegeln Budgets auch die Geschlechterverhältnisse wider und wirken infolge der differenten sozioökonomischen und gesellschaftlichen Positionen von Frauen und Männern als Arbeitskräfte, im Haushalt, in der Familie und in der Gesellschaft ,unterschiedlich auf Frauen und Männer und (re-) produzieren damit Geschlechterungleichstellung und die ungleiche Verteilung von Macht zwischen den Geschlechtern" (Michalitsch 2003: 228).

Gender Budgeting zielt demgemäß im Wesentlichen darauf ab, die geschlechtliche Strukturierung und geschlechtsspezifische Auswirkungen von Budgets zu eruieren um eine geschlechtergerechte Finanzpolitik - eine Revision öffentlicher Budgets hin zu einer Orientierung an Geschlechtergleichstellung - zu erwirken. Hierbei werden die Staatseinahmen und -ausgaben aus der Geschlechterperspektive untersucht (vgl. Angelo et al 2003: 26), also eine „genderbezogene Analyse sowie die Bewertung der Verteilung von Ressourcen aus Gleichstellungsperspektive" (Schratzenstaller et al 2006: 2) vorgenommen. Demnach beinhaltet Gender Budgeting eine geschlechtsspezifische Analyse, Bewertung und letztlich Revision von Budgets und sollte zumindest die Stufen „Planung und Vorbereitung, Annahme, Vollzug, Audit und Evaluierung" (Michalitsch 2003: 229) des Budgetprozesses umfassen.

Absicht ist zu untersuchen ob Budgets Geschlechtergerechtigkeit fördern oder verhindern. Die Schlüsselfrage ist: Welche Auswirkung haben budgetpolitische Größen und Maßnahmen auf die Gleichstellung der Geschlechter? Reduzieren sie Geschlechterungleichheiten, vergrößern sie sie oder lassen sie sie unverändert (vgl. Elson 1999: 17, Elson 2002a: 16)? In einem weiteren Schritt soll eine veränderte Prioritätensetzung der Finanzpolitik ,towards gender-equitable patterns of revenue collection and resource use" (Cagatay et al 2000: 38) erwirkt werden.

Für Gender Budgeting sind also in jedem Fall folgende zwei Aspekte wesentlich: zum einen die inhaltliche Gestaltung von Budgets beziehungsweise die ,inhaltlichen Forderungen an die Budgetpolitik" (Angelo et al 2003: 33) und zum anderen auf Ebene des Budgetprozesses, die „Erreichung eines transparenten Prozesses der Budgeterstellung" sowie eines partizipativen Prozesses, also die Schaffung von „Möglichkeiten zur Einflussnahme auf Budgetprioritäten“ (BEIGEWUM 2002: 16). Wobei das Ziel von Gender Budget-Initiativen die Gleichstellung von Frauen und Männern ist (vgl. Schratzenstaller et al 2006: 6). 
Anhand dieser beiden Oberziele können drei grundlegende Ziele von Gender Budgeting identifiziert werden: Erstens zielen sie darauf ab, Aufmerksamkeit auf die geschlechtsspezifischen Auswirkungen und Effekte von Budgets und Finanzpolitik zu lenken, Bewusstsein für die geschlechtsspezifischen Wirkungsweisen öffentlicher Ausgaben und Einnahmen zu schaffen und die Kategorie Gender in den Mainstream aller Politiken zu bringen. Zweitens sollen sie Regierungen ,accountable for their commitments to gender equality" (Sharp/Broomhill 2002: 32) machen. Und drittens wollen Gender Budget-Initiativen Änderungen von Budgets und Politiken ,that would raise the social and economic status of women and further gender equality" (ebd.) erwirken - also geschlechtsspezifische sozioökonomische Ungleichheiten reduzieren und Gleichstellung fördern. „Zentriert um gleichstellungsorientierte Restrukturierung öffentlicher Finanzen sowie mit diesen verbundenen Politiken wollen Gender-Budget-Initiativen letztlich (...) den Einsatz öffentlicher Ressourcen in Hinblick auf GenderGerechtigkeit verbessern (Michalitsch 2003: 230).

Gender Budgeting wird auch als ein sich wiederholender Prozess aus Konsultation, Partizipation, Planung, Implementierung und Evaluation anhand eines Sets von Zielen, Indikatoren und Benchmarks bezeichnet, dessen regulärer Review und Überarbeitung ,based on emerging experiences“ den „critical factor in improving the design and implementation of the programme and strengthening its impacts“"(Hewitt/Mukhopadhyay 2002: 77) darstellt.

\subsection{Finanzpolitik}

Ausgangspunkt der deutschsprachigen Gender Budgeting-Literatur ist die Forderung nach einer "genderspezifischen“ (Bergmann et al 2004: 7), einer „geschlechterspezifische(n)“ (Michalitsch 2006: 22) oder einer "geschlechtergerechte(n) Budgetpolitik“ (Klatzer 2003: 31). Grundlegende Idee ist „die Einbeziehung der Gender Perspektive in die Wirtschafts- und Budgetpolitik" (Klatzer 2003: 4), um den Umständen gerecht zu werden, dass Frauen und Männer unterschiedliche wirtschaftliche und gesellschaftliche Positionen vorfinden, von staatlichen Politiken und Maßnahmen unterschiedlich betroffen sind und dem Staat gegenüber unterschiedliche Bedürfnisse haben (vgl. Bergmann et al 2004: 7, BEIGEWUM 2002: 12f).

Budgetpolitik wird in BEIGEWUM (2002: 10) als Teil der Wirtschaftspolitik definiert: „Mit Einnahmen (Steuern, Gebühren und Beiträgen, öffentlicher Verschuldung und Vermögensveräußerung etc.) und Ausgaben (Investitionen, Gehälter, Darlehen, Transfers etc.) hat der Staat Lenkungs- und Verteilungsfunktion zu erfüllen". Dieser Definition zufolge würde Budgetpolitik gemäß eines formalen Verständnisses von Budget als „Gegenüberstellung von Einnahmen und Ausgaben" (Angelo et al 2003: 29) die staatliche Einnahmen- und Ausgabenpolitik bezeichnen. 
Hierbei würde sich Gender Budgeting jedoch ausschließlich auf die Ablaufpolitik im Zusammenhang mit Budgets konzentrieren und die ordnungspolitischen Rahmenbedingungen wie Institutionen, Regeln und Zuständigkeiten außer Acht lassen.

Gender Budget-Initiativen geht es jedoch um mehrere Aspekte, wie beispielsweise die inhaltliche Gestaltung von Budgets, die Erreichung eines transparenten Budgeterstellungsprozesses ebenso wie eines partizipativen Prozesses mit Möglichkeiten der Einflussnahme auf die Budgetprioritäten (vgl. BEIGEWUM 2002: 16) und damit um mehr als um eine bloße Veränderung der Einnahmenund Ausgabenpolitik.

Welcher Teilbereich der Wirtschaftspolitik soll also mit Hilfe von Gender Budgets verändert werden? Die Budgetpolitik, die Finanzpolitik oder die Fiskalpolitik?

In der finanz- und wirtschaftspolitischen Literatur werden heute die Begriffe Budget-, Finanz- und Fiskalpolitik vielfach undifferenziert, substituierend oder synonym $^{4}$ verwendet. Wird beispielsweise der Terminus Budgetpolitik im Stichwortregister von Reinhard Neck et al gesucht, so findet sich der Verweis „siehe Finanzpolitik“. Ebenso wird auch bei der Suche nach Fiskalpolitik auf die Finanzpolitik verwiesen. Im Text werden dann alle drei Begriffe folgendermaßen synonym verwendet: „...im Bereich der Fiskalpolitik (Budgetpolitik, Finanzpolitik)..." (Neck et al 2001: 53). Unter anderen verwendet auch Fritz Breuss den Begriff Budgetpolitik grundsätzlich in Verbindung mit Fiskalpolitik folgendermaßen: „...Wirtschaftspolitik (insbesondere Fiskal- bzw. Budgetpolitik)...“

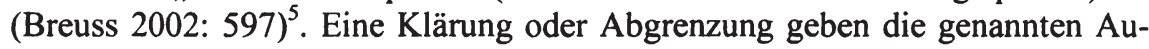
toren nicht. Auch in der angloamerikanischen Literatur wird Budgetpolitik, „the choice of taxes and spending by the government" (Blanchard 2000: 46) oder „the government's choice regarding levels of spending and taxation" (Mankiw 2000: 536) mit der „fiscal policy” (Fiskalpolitik) gleichgesetzt, beides bezieht sich ,auf die Steuer- und Ausgabenpolitik des Staates” (Samuelson/Nordhaus 1998: 736$)^{6}$.

4 Schon 1986 unterstrich Karl-Heinrich Hansmeyer dass der Begriff Budgetpolitik einer Interpretation bedarf und er ,synonym für Finanz- und Haushaltpolitik stehen“ (Hansmeyer 1986: 11) könne.

5 So wird auch für verwandte Begriffe wie beispielsweise die Budgetinstitution als Synonym fiskalische Institution verwendet, dasselbe gilt auch für den Terminus Budgetregel (fiskalische Regel) (vgl. Pasterniak 2006: 9).

6 Vergleiche zur Verwendung der Termini Fiskalpolitik und Finanzpolitik auch Cassel/ Thieme (2007) oder Ahrns/Feser (1997), die die Fiskalpolitik jeweils als den Einsatz von öffentlichen Finanzen zur Verwirklichung gesamtwirtschaftlicher Ziele sehen, dies jedoch in Kapiteln zur Stabilisierungspolitik darstellen und somit vermuten lassen, dass sie ,gesamtwirtschaftliches Ziele“ ausschließlich mit dem Stabilisierungsziel gleichsetzen. 
Für Gender Budgeting braucht es jedoch eine Differenzierung dieser drei Begriffe, ihre Klärung sowie eine Ein- beziehungsweise Unterordnung in die Wirtschaftspolitik, die ich im Folgenden anhand eines Reviews wirtschaftspolitischer Mainstream-Literatur erarbeiten möchte:

In seinem Überblick über die öffentliche Finanzwirtschaft und die Finanzwissenschaft bezeichnet Heinz Grossekettler die Finanzwissenschaft als die „Summe aller Aussagen darüber, welche ökonomischen Aufgaben der Staat in einer Wirtschaft mit Hilfe von Ausgaben und Einnahmen und Regeln für deren Planung und Kontrolle erfüllt oder erfüllen sollte" (Grossekettler 2007: 563). Analyse, Erklärung und Begründung dieser Staatstätigkeit ist Aufgabe der Finanztheorie, die „Untersuchungen theoriegestützter Einsatzmöglichkeiten von Instrumenten zur Erreichung von Zielen und Analysen der zugehörigen Gestaltungsmöglichkeiten bilden die theoretische Finanzpolitik" (ebd.).

Hierbei gehören die durch die Haushaltspläne, also das Budget, festzulegenden Ausgaben zur finanzwirtschaftlichen Prozesspolitik, während die „durch materielle Gesetze festzulegenden Ausgaben und Einnahmen sowie die Planungsund Kontrollvorschriften" (ebd.) Teil der finanzwirtschaftlichen Ordnungspolitik sind ${ }^{7}$. Die theoretische Finanzpolitik beschreibt Grossekettler als Teil der Theorie der Wirtschaftspolitik i.w.S., die sich von der Theorie der Wirtschaftspolitik i.e.S. dadurch unterscheidet, dass sie die wirtschaftliche Tätigkeit und die budgetgesteuerte Finanzpolitik öffentlicher Verbände untersucht „und sich bezüglich der Beeinflussung des Verhaltens von Privaten auf die Erforschung der (potentiellen) Rolle öffentlicher Einnahmen und Ausgaben beschränkt" (ebd.), während die Wirtschaftspolitik i.e.S. alle anderen Instrumente wie beispielsweise die Geldpolitik oder die Regulierungstätigkeiten der öffentlichen Verwaltungen beinhaltet. „Hauptakteure in der Finanzpolitik sind die Finanzministerien“ (ebd.). Träger der Finanzpolitik sind die Gebietskörperschaften ebenso wie die Para- und Hilfsfisci (vgl. Grossekettler 2007: 567 und Zimmermann/Henke 2001: 7f).

Gerhard Graf beschreibt die Finanzpolitik als einen „Teilbereich staatlicher Politik, die von der Außen- und Militärpolitik bis zu Justiz- und Kulturpolitik reicht“ (Graf 2005: 19), denn alle Politikbereiche gehen in der Regel mit finanziellen Strömen einher und haben ,auch wenn sie sich auf die Setzung von Normen be-

7 Die ordnungs- und prozesspolitischen Aspekte der Finanzpolitik beschreibt auch Stefan Bajohr folgendermaßen: „Indem die Finanzpolitik beispielsweise darüber entscheidet welche Steuern erhoben und welche abgeschafft werden, interveniert sie ordnungspolitisch zulasten oder zugunsten" von Wirtschaftssubjekten und ,indem sie [Beschlüsse] über die Größe der staatlichen Einnahmen und Ausgaben, über die Aufnahme von Krediten, die Tilgung von Schulden, über den Erwerb oder die Veräußerung von Vermögensgegenständen" fasst „wirkt die Finanzpolitik prozesspolitisch auf die Verteilung von Verantwortung, Ressourcen und Entscheidungsmacht in der Gesamtwirtschaft“ (Bajohr 2003: 16). 
schränken im Allgemeinen jeweils ökonomische Auswirkungen“" (ebd.). Graf konkretisiert diese Definition, indem er den Terminus Finanzpolitik als jenen engeren Teilbereich der allgemeinen Wirtschaftspolitik ${ }^{8}$ versteht, „mit dem bewusst und vorrangig durch Beeinflussung und Veränderung staatlicher Einnahmen und Ausgaben gesellschaftliche und insbesondere wirtschaftliche Ziele angestrebt werden" (ebd.).

Klaus Staender definiert den Begriff der Finanzpolitik in seinem Lexikon der öffentlichen Finanzwirtschaft etwas abweichend als Teil der allgemeinen Wirtschaft- und Gesellschaftspolitik, dessen Aufgabe der zielgerichtete Einsatz von finanzwirtschaftlichen Maßnahmen zur Erfüllung von Staatsaufgaben ist (vgl. Staender 2004: 178).

Ebenso verstehen auch Herbert Wiesner, Bodo Leibinger und Reinhard Müller die Finanzpolitik als Teil der allgemeinen Wirtschaftspolitik sowie der Gesellschaftspolitik und zwar als denjenigen Teil der, ,über die öffentlichen Haushalte [Budgets] vollzogen wird" (Wiesner et al 2004: 11). Die Aufgabe der Finanzpolitik ist ihrer Auffassung nach die Beschaffung, die Verwaltung und die Verwendung der Deckungsmittel, die für die Ausgaben zum Zweck der staatlichen Aufgabenerfüllung erforderlich sind. Hierbei übt die Finanzpolitik sowohl eine Allokations-, eine Distributions- als auch eine Stabilisierungsfunktion aus. „Die Finanzpolitik ist somit die Summe aller politischen Entscheidungen zur Gestaltung und Lenkung der staatlichen Einnahmenwirtschaft und Ausgabenwirtschaft zum Zwecke staatlicher Aufgabenerfüllung“ (ebd.).

Etwas abweichend beschrieb Wiesner schon in seinen frühen Publikationen die Aufgaben der Finanzpolitik als Beschaffung, Verwaltung und Verwendung öffentlicher Mittel zur ,staatlichen Aufgabenerfüllung in Form der Bereitstellung öffentlicher Güter und Dienstleistungen (=klassische finanzwirtschaftliche Bedarfsdeckungsfunktion), zur Erreichung wirtschaftspolitischer und sozialpolitischer Ziele (=moderne gesamtwirtschaftliche Lenkungsfunktion) [sowie] zur Gestaltung internationaler wirtschafts- und währungspolitischer Finanzbeziehungen (=übernationale finanzpolitische Funktion)“(Wiesner 1986: 25).

8 Die Verschränkung der Finanz- und allgemeinen Wirtschaftspolitik skizzierte auch Fritz Neumark: Das Budget ist „Ausdruck einer bestimmten wirtschaftspolitischen Zielsetzung (...), die mit der Finanzpolitik verfolgt wird", außerdem ermöglicht es eine Abstimmung der öffentlichen Haushaltsführung auf die allgemeine Wirtschaftspolitik von der es materiell wie formell einen höchst bedeutsamen Teil bildet (vgl. Neumark 1952a: 559). Wie die Finanzpolitik so ist auch das Budget, das , jene verkörpert (...) nicht lediglich ein Instrument von rein finanzwirtschaftlichem Interesse, sondern darüber hinaus ein Ordnungsmittel, das der Realisierung und Rationalisierung einer bestimmte Wirtschaftspolitik die$n t^{\prime \prime}$ (ebd. Hervorhebung im Original). 
Klaus Schubert und Martina Klein verstehen unter dem Begriff der Finanzpolitik eine „Sammelbezeichnung für alle politischen und gesetzgeberischen Maßnahmen, die der Ordnung und Gestaltung der öffentlichen Einnahmen und Ausgaben (Staatsfinanzen) dienen" (Schubert/Klein 2006: o.S).

Auch Bernhard Felderer und Stefan Homburg unterstreichen, dass Finanzpolitik ,alle Maßnahmen [umfasst], welche die Budgets oder Haushaltpläne der Gebietskörperschaften betreffen" (Felderer/Homburg 2003: 158). Auch sie sehen die Aufgabe der Finanzpolitik in der Erfüllung von Allokations-, Distributionsund Stabilisierungszielen ${ }^{9}$ durch die „Handhabung von Budgets also durch Festlegung von Höhe und Art" (ebd.).

Felderer und Homburg verstehen die Finanzpolitik nicht so sehr als Teilbereich, sondern als Mittel der Wirtschaftspolitik. Und unterscheiden wiederum als den Teil der Finanzpolitik, der „unmittelbar dem Stabilisierungsziel zugewandt ist“ (Felderer/Homburg 2003: 158) die Fiskalpolitik. Diese Unterscheidung teilen auch Staender, der die Fiskalpolitik als Finanzpolitik i.e.S. definiert, deren Aufgabe es ist konjunkturelle Schwankungen zu vermeiden (vgl. Staender 2004: 178) sowie Horst Zimmermann und Klaus-Dirk Henke, deren Glossar Fiskalpolitik als „den Einsatz der öffentlichen Finanzen im Dienste der Konjunkturund Wachstumspolitik“ benennt (Zimmermann/Henke 2001: 474). „Staatliche Stabilisierungspolitik, durch die der Budgetsaldo variiert wird, bezeichnet man auch als Fiskalpolitik“ (Grossekettler 2007: 565). Auch Ewald Nowotny übersetzt die englische „Fiscal Policy“" als fiskalische Stabilisierungspolitik und versteht darunter den „Versuch, die Volkswirtschaft durch nachfragesteigernd (expansiv) bzw. nachfragedämpfend (kontraktiv) wirkende Steuer- und Ausgabenvariationen des Staates in die erwünschte Richtung - zur optimalen Auslastung - zurückzuführen" (Nowotny 1999: 585) um auftretende Konjunkturschwankungen zu dämpfen.

Die Finanzpolitik ist des Weiteren jedenfalls von der Politik des Finanzsektors abzugrenzen. Alle Bestände des Finanzvermögens einer Volkswirtschaft werden vom geldwirtschaftlichen Sektor, der auch Finanzsektor genannt wird, umfasst. Jener Teil der Wirtschaftspolitik, der mit den Größen dieses Sektors befasst ist, wird als Geldpolitik bezeichnet (Winckler 1997: 264).

Außer in der oben erwähnten amerikanischen Literatur wird der Begriff Budgetpolitik zwar regelmäßig und zumeist als Substitut für den Terminus Finanzpolitik verwendet, jedoch finden sich in der finanzwissenschaftlichen Literatur kaum Definitionen $^{10}$. Die vorhandenen Definitionen von Budgetpolitik sind hierbei äu-

9 Die dreiteilige Aufgabengliederung nach Allokations-, Distributions- und Stabilisierungsaufgaben geht ursprünglich auf Richard Musgrave (1959) zurück.

10 Im Zuge der oben dargestellten undifferenzierten Verwendung der Begriffe ist jedenfalls interessant herauszufiltern, wann und in welchem Zusammenhang eher „Budgetpolitik“ 
Berst eng gefasst, wie beispielsweise die von Gustav Hafner et al: Budgetpolitik ist die Ausrichtung des öffentlichen Haushaltes auf gesamtwirtschaftliche Ziele, dabei geht es um die Aufteilung finanzieller Mittel auf den öffentlichen und privaten Sektor zur Sicherung eines ausgeglichenen Wirtschaftswachstum, zur Erreichung einer Vollbeschäftigung sowie zum Erhalt des Geldwertes (vgl. Hafner et al 1995: 51) $)^{11}$

Für ein Gender Budgeting, dessen Grundidee eine Verankerung von Gleichstellungspolitik ,als zentraler Bestandteil der Wirtschafts- und Gesellschaftspolitik“ (BEIGEWUM 2002: 14) ist, sollte daher meiner Meinung nach anstelle von Budgetpolitik im Sinne einer Einnahmen- und Ausgabenpolitik, Finanzpolitik als Ausgangspunkt dienen. Hierbei verstehe ich Finanzpolitik, in Anlehnung an Wiesner et al, als Teil der Wirtschaftspolitik sowie der Gesellschaftspolitik, der alle politischen und gesetzgeberischen Entscheidungen und Maßnahmen zur Ordnung, Gestaltung und Lenkung der Budgets der Gebietskörperschaften umfasst und mit der, in Anlehnung an Graf, durch Beeinflussung und Veränderung der Einnahmen und Ausgaben gesellschaftliche und wirtschaftliche Ziele angestrebt werden. Demgemäß beinhaltet die Finanzpolitik sowohl die finanzwirtschaftliche Prozesspolitik - das Budget - als auch die finanzwirtschaftliche Ordnungspolitik - wie materielle Gesetze, Planungs- und Kontrollvorschriften. Die Aufgabe der Finanzpolitik ist in diesem Sinn die zielgerichtete Beschaffung,

als „Finanzpolitik“ verwendet wird: Angelika Pasterniak (2006: 107ff) skizziert beispielsweise den Wandel der österreichischen Finanzpolitik und verwendet den Terminus Budgetpolitik für die Regierungsperiode 1987 bis 1990 in der „Budgetkonsolidierungen im Vordergrund" (Pasterniak 2006: 110,) standen. Auch in der zweiten Hälfte der 1990er Jahre beruhte „,der Schwerpunkt der Budgetpolitik (...) auf der Budgetkonsolidierung“ und erst im Jahr 2003 wurden ,wieder verstärkt Bekenntnisse zu einer aktiven Finanzpolitik abgelegt" (Pasterniak 2006: 115). Hansmeyer verwendet den Begriff der Budgetpolitik im Zusammenhang mit der „Zielstruktur des Budgets“ (Hansmeyer 1986: 11) und untersucht in „Budgetpolitik im Wandel“ die Wandlungen dieser Zielstrukturen.

Auch Neumark betitelt ein Unterkapitel seiner „Prinzipien der interventionistischen $F$ inanzpolitik“ mit „Voraussetzungen und Erfolgsbedingungen der modernen Budgetpolitik" und fokussiert dabei die Politik des Budgetausgleichs" (Neumark 1952b: 662; Hervorhebungen jeweils durch die Autorin).

Diese exemplarische Literatur seit 1952 lässt vermuten, dass der Begriff Budgetpolitik und seine Verwendung im Zusammenhang mit den veränderten Zielen der Finanzpolitik stehen und vor allem mit dem Wandel in Richtung Outputorientierung forciert zum Einsatz kam.

11 Das österreichische Finanzministerium definiert Budgetpolitik sogar noch enger als „den Rahmen innerhalb dessen Ausgaben getätigt und durch Einnahmen oder Schuldenaufnahme finanziert werden", die dazugehörigen Steuerungsgrößen sind die Ausgabenquote, die Steuer- und Abgabenquote jeweils in Prozent des BIP und das Nettodefizit also die aus der Differenz zwischen Ausgaben und Einnahmen bedingte Zunahme an Staatsschulden (vgl. www.bmf.gv.at/Budget/Budget politik/_start.htm) 
Verwaltung und Verwendung finanzwirtschaftlicher Mittel zur Erfüllung von Staatsaufgaben. Finanzwirtschaftliche Instrumente sind das Budget beziehungsweise die im Budget gegenübergestellten Einnahmen und Ausgaben, durch deren Variation in Art und Höhe finanzpolitische Ziele verfolgt werden können. Die Fiskalpolitik mit ihrem spezifischen Stabilisierungsziel stellt im Zuge einer solchen Abgrenzung einen Teil der Finanzpolitik dar.

\subsection{Emanzipation}

Große Erwartungen werden in Gender Budgeting als ein emanzipatorisches Instrument (Mayrhuber 2006: 25), ein „Instrument für emanzipatorische Politik“ (Schlager 2006: 100) und einen emanzipatorischen, transformativen Ansatz (vgl. Klatzer 2004: 24) gesetzt. Da Finanzpolitik ,emanzipatorisch wirken oder ungleiche Strukturen verfestigen“ (BEIGEWUM 2002: 180) kann, soll Gender Budgeting als ,,angewandte emanzipatorische Wirtschaftspolitik (Klatzer 2003: 297) fungieren. Gender Budgeting wird ein großes emanzipatorisches Potential zugeschrieben, „but this potential has not yet been realized” (Elson 2006: 96).

Was unter Emanzipation zu verstehen ist und wie ich den Begriff für diese Dissertation definiere, möchte ich im Folgenden klären:

Der dem Lateinischen „emancipare“ beziehungsweise „emancipatio“ entstammende Begriff der Emanzipation bezeichnet die „Befreiung aus einem rechtlichen, politischen oder sozialen Abhängigkeitsverhältnis“ (Wisniewski/Kunst 1988: 134) ebenso wie die „Befreiung von Individuen oder Gruppen, die zuvor rechtlich oder tatsächlich in einem dauernden Abhängigkeitsverhältnis standen" (Brockhaus 1968: 484). Der ursprüngliche Sinn wurde im römischen Recht begründet und meinte das „Entlassenwerden aus Gewaltverhältnissen, die im sozialen Kontext als ,natürlich' gelten“ (Kroll 2002: 80), ein erwachsener Sohn oder ein Sklave wurde aus der väterlichen Gewalt - ,aus dem manicipium“ (Brockhaus 1968: 484) - entlassen.

„Das zeitgenössische Emanzipationsverständnis geht auf die Aufklärung zurück und ist eng mit der Entwicklung der modernen Gesellschaften verknüpft“ (Kroll 2002: 80). In der Zeit der Aufklärung bezeichnete Emanzipation die „Herausführung aus der Unmündigkeit“" sowie die Herausführung aus den „einfachen, dem Gesetz der Natur und des Zufalls unterworfenen, heteronomen Formen des sozialen Zusammenlebens" (Demirovic 2001: 13).

So bedeutete Emanzipation in den Sozialbewegungen des 18. und 19. Jahrhunderts die „Befreiung des Bürgertums aus ökonomischen, politischen, sozialen und geistigen Abhängigkeitsverhältnissen“ (Kroll 2002: 80). Ziel war eine Überwindung der ,althergebrachten ständischen Ordnung und der Sozialstrukturen“ (Wisniewski/Kunst 1988: 134). In der Folgezeit wurde Emanzipation auf die Befreiung von Gesellschaften, Gruppen, Klassen, ArbeiterInnen und Frauen aus 
Zwangs- und Abhängigkeitsverhältnissen ausgedehnt. Des Weiteren entwickelte sich der Begriff der Emanzipation von dem Verständnis eines passiven Freilassens oder Befreiens zu einem Terminus der aktiven Selbstbefreiung (vgl. Kroll 2002: 80).

Heute wird Emanzipation zumeist ausschließlich auf die Bestrebungen von Frauen eingeschränkt, ,aus der traditionellen Frauenrolle mit allen Beschränkungen der aktiven Teilnahme am öffentlichen, gesellschaftlichen und kulturellen Leben auszubrechen und volle Gleichberechtigung sowie soziale Unabhängigkeit zu erlangen" (ebd.). Hierbei handelt es sich um eine faktische Überwindung sozialer Abhängigkeiten von Frauen, die bislang hinter der rechtlichen Gleichstellung zurückgeblieben ist (vgl. ebd.) und im Zuge dessen um eine „tatsächliche Verwirklichung der Gleichberechtigung [von Frauen] in allen Bereichen des gesellschaftlichen Lebens"(Wisniewski/Kunst 1988: 134).

Für meine Dissertation möchte ich diesen mittlerweile auf Frauenemanzipation beschränkten Begriff jedoch ausdehnen und unter Emanzipation eine gesamtgesellschaftliche Emanzipation verstehen. Gesamtgesellschaftliche Emanzipation bedeutet - in Anlehnung an Alemann (1975: 39) - eine Herausführung und (Selbst-)Befreiung aus Unterdrückung, Ungleichheit und Unmündigkeit um Selbstbestimmung und Selbstverwirklichung aller (Unterdrückten, Ungleichen und Unmündigen) zu erwirken - sowohl im Sinne von Autonomie im individuellen Bereich, wie auch im Sinne von Gleichheit im kollektiven Bereich. Vor dem Hintergrund der spezifischen Abhängigkeiten und der rechtlichen, politischen, ökonomischen, sozialen und kulturellen Benachteiligungen von Frauen hat eine solche gesamtgesellschaftliche Emanzipation für Frauen eine besondere Bedeutung. Demgemäß folgt für die Verwendung des Begriffes, dass eine gesamtgesellschaftliche Emanzipation Frauenemanzipation im Besonderen beinhaltet.

\subsection{Demokratie und Demokratisierung}

Eng mit den Erwartungen an das emanzipatorische Potential von Gender Budgeting sind Forderungen nach einer „Öffnung und Demokratisierung des Budgetprozesses“ (BEIGEWUM 2002: 190) sowie der Wirtschaftspolitik im Allgemeinen verbunden. Daher werde ich im Folgenden die Termini Demokratie und Demokratisierung genauer untersuchen und für die vorliegende Dissertation klären.

\subsubsection{Demokratie}

Der dem Griechischen entstammende Fachbegriff Demokratie kann leicht an seiner wörtlichen Urbedeutung festgemacht werden. Er setzt sich aus „demos“, dem griechischen Wort für Volk oder Volksmasse, und „kratein“, was in der 
deutschen Übersetzung ,herrschen“ oder „Macht ausüben“ bedeutet, zusammen. Im wörtlichen Sinn bedeutet Demokratie also „Macht des Volkes, [also] dass dem Volke die Macht gehöre“ (Sartori 1992: 15). Insoweit könnte Demokratie knapp und bündig als Herrschaft beziehungsweise Machtausübung des Volkes oder als eine legitime Herrschaft, die vom Volk ausgeht, durch das Volk ausgeübt und „zum Nutzen des Staatsvolkes eingesetzt“ (Schmidt 2000:19) wird, definiert werden.

Eine solche Definition ist jedoch nur eine „von Wörtern durch Wörter, die in einer geläufigen Sprache die griechische Wortbedeutung wiedergibt“". Dies hält Giovanni Sartori nicht für ausreichend, denn der Ausdruck Demokratie „bezeichnet ja etwas". Deshalb stellt sich nicht nur die Frage was das Wort Demokratie an sich bedeutet, sondern auch „welcher Gegenstand damit bezeichnet wird" (Sartori 1992:15). Beim Versuch eine Beantwortung auf diese Frage zu geben, ist jedoch festzustellen, dass in der heutigen Wirklichkeit „der Gegenstand nicht dem Wort entspricht oder ihm hinreichend ähnlich ist. Wir stellen somit fest, dass Tatsachen und Name schlecht zusammenpassen" (ebd.). Denn „schaut man sich die Staaten, die sich demokratisch nennen, der Reihe nach an, entdeckt man schnell solche, in denen das Volk wenig bis gar nichts zu sagen, geschweige denn zu herrschen hat" (Lambertz 1984: 15). Dementsprechend braucht es bei dem Versuch Demokratie zu definieren ,gewissermaßen eine deskriptive und eine präskriptive Definition. Die eine kann ohne die andere nicht bestehen und auch nicht durch sie ersetzt werden". Es darf nicht übersehen werden, ,a) dass das demokratische Ideal nicht die demokratische Wirklichkeit definiert und dass umgekehrt die reale Demokratie nicht dasselbe wie eine ideale ist und sein kann; und b) dass die Demokratie aus den Wechselwirkungen zwischen ihren Idealen und ihrer Wirklichkeit entsteht und gestaltet wird, aus dem Drang eines Sollens und dem Widerstand eines Seins" (Sartori 1992: 17).

Mittlerweile dient Demokratie als ein Sammel- beziehungsweise Oberbegriff für Formen politischer Machtausübung bzw. Herrschaft, also für eine Vielzahl von Regierungsformen und politischen Ordnungen, denen der Anspruch gemeinsam ist, die Herrschaftsgrundlage aus dem Volk abzuleiten und auf den Willen des Volkes - oder auf zumindest einen großen Teil der StimmbürgerInnenschaft zu gründen sowie dies mit einer Rechenschaftspflicht der Herrschenden zu verbinden (vgl. Schmidt 2000: 19f). Demokratie wird also als Form von Herrschaftslegitimation - mit der Gründung auf den Willen der StimmbürgerInnen und Herrschaftskontrolle präzisiert (vgl. Abromeit 2002: 70).

Eine deskriptive Beschreibung von Demokratie ist bei Manfred G. Schmidt zu finden: Demokratie ist eine „Staatsverfassung von Klein- und Flächenstaaten, in der die Herrschaft auf der Basis politischer Freiheit und Gleichheit sowie weit reichender politischer Beteiligungsrechte der Bevölkerung im Erwachsenenalter mittel- oder unmittelbar aus dem Staatsvolk hervorgeht, in wettbewerblich orga- 
nisierten Willensbildungs- und Entscheidungsprozessen erörtert und unter Berufung auf das Interesse der Gesamtheit oder der Mehrheit der Stimmberechtigten ausgeübt wird, und zwar unter dem Damoklesschwert der Abwahl der Regierenden durch das Volk oder dessen Vertreter" (Schmidt 2000: 21f). Diese ziemlich sperrige Definition sieht er als Korrektur der unrealistischen GettysburgFormel, die Abraham Lincoln folgendermaßen entwickelte: ,government of the people, by the people, and for the people". Jedoch reicht auch diese Korrektur nicht aus um das gegenwärtig herrschende Demokratieverständnis zu beschreiben, denn ,in vielen Angelegenheiten herrscht nachweislich weder das Volk noch die Volksvertretung, sondern vielmehr die Judikative oder die Bürokratie, mitunter im Verein mit der Regierung“" (ebd.: 22).

Ähnlich fasst Giovanni Sartori die Charakteristika bestehender moderner Demokratien folgendermaßen zusammen: Sie „,beruhen auf a) beschränkter Mehrheitsherrschaft, b) Wahlverfahren und c) der repräsentativen Übertragung von Macht. Daraus folgt, dass innerhalb des Volkes einige Menschen mehr und einige weniger zählen (...) und dass vieles, was als ,Wille' des Volkes bezeichnet wird eher einer ,Zustimmung' des Volkes ähnelt" (Sartori 1992: 39).

In einem solchen - heute vorherrschenden - repräsentativen Demokratieverständnis wird Demokratie nicht mehr als Regierung des Volkes betrachtet, sondern vielmehr als „Regierung des Volkes durch eine aus dem Volk hervorgegangene Elite“ (Duverger 1959: 431 zit. in Schmidt 2000: 179). In den repräsentativen Systemen westlicher Demokratien werden VolksvertreterInnen gewählt, die im Auftrag des Volkes Herrschaft ausüben und souverän sowie ohne direkte Möglichkeit des Eingriffes durch das Volk politische Entscheidungen treffen.

In Abgrenzung zu einem Demokratieverständnis, bei dem die Bürgerinnen und Bürger direkt und unmittelbar über alle politischen Angelegenheiten entscheiden können, muss heute von einer demokratischen Elitenherrschaft gesprochen werden. „Zwar gibt es noch Rudimente der direkten Demokratie, doch werden in der Regel politische Entscheidungen von gewählten Vertretern des Volkes getroffen“ (Lambertz 1991: 4). Demokratie stellt oftmals schlicht ein „mehrheitsbezogenes Verfahren der Elitenauswahl und Entscheidungsfindung" (Sauer 2003: 15) dar. Westliche Politik, „die nur Eliten und Massen kennt" - um Benjamin Barbers pointierte Formulierungen zu verwenden - gibt sich also als Demokratie aus (vgl. Barber 1994: 99).

Viktor Scherz fasst den derzeitigen demokratischen Status quo folgendermaßen zusammen: „Wettbewerb von politischen Parteien, begrenzte Mitbestimmungsmöglichkeiten in Form von Wahlen und organisierten Interessensvertretungen, verfassungsmäßige Beschränkungen der Staatsaktivitäten und die Abschottung der Wirtschaft von demokratischen Mechanismen sind [die] wesentliche Elemente" (Scherz 2001: 82) der modernen repräsentativen Demokratien. 
Ähnlich beschreibt auch Birgit Sauer die „demokratische Lücke“ des repräsentativen Demokratiemodells, die „durch unterkomplexe und starre Formen politischer Willensbildung und Entscheidung" (Sauer 2001: 172) entstanden ist: Während Eliten, zusammengesetzt aus den Spitzen von Parteien und Fraktionen, hohen Bediensteten der Ministerien und „Wirtschaftsführern“, die politischen Entscheidungsprozesse übernehmen, werden die Handlungs- und Entscheidungsfähigkeit des Volkes auf Wahlen beschränkt, wodurch das Volk „zum bloßen Publikum in der Zuschauerdemokratie degradierte" (ebd.).

Diese Zuschauerdemokratie wird forciert, indem „we are only called to participate in democracy every four years, when we go to the ballot box. In the interim we are asked to go home, watch the show on TV and become political couch potatoes until the next election" (Schugurensky 2004: 2). Wahlen stellen etwas Gelegentliches dar, zwischen ihnen „bleibt die Volksmacht weitgehend passiv“ (Sartori 1992: 94) - zwischen den "Wahlterminen wird das Volk regiert" (Lambertz 1984: 26). Abgesehen davon können auch Wahlen nicht per se als „Akt politischer Selbstbestimmung" der Bürgerinnen und Bürger beschrieben werden, sondern vielmehr als „Ritual der Abschirmung der administrativen Entscheidungsebene, das spezifische Gruppen und Issues aus den repräsentativ legitimierten Entscheidungsinstitutionen exkludiert" (Sauer 2001: 172). Denn Wahlen setzen jedenfalls ,keine Programme in Kraft, sondern entscheiden, wer das tun wird. Wahlen entscheiden keine Sachprobleme, sondern sie entscheiden, wer sie entscheidet“" (Sartori 1992: 119).

Repräsentation und Wahl sind also die „Achillesferse“ von Demokratien, denn "Wahlen sind nicht notwendig frei; und die Repräsentation ist nicht unbedingt eine echte" (ebd.: 40). Dies unterstreicht auch Sauer: Mit dem Repräsentationsgedanken sind „fundamentale Defizite westlicher Demokratien verknüpft: Das Prinzip der Repräsentation überlässt politische Entscheidungen einer kleinen Elite und damit häufig dem Machtkalkül von Parteien. Darüber hinaus verengt die Idee der Repräsentation den partizipativen Gedanken: Der Souverän kann nur Personalentscheidungen treffen, ein generelles Selbstregierungsrecht ist ihm entzogen" (Sauer 2003: 12).

Ulrich Beck zeichnet gar das Bild einer „demokratischen Monarchie“, deren demokratische Regeln auf die Wahlen von politischen Repräsentantinnen und Repräsentanten und die teilweise Mitwirkung an politischen Programmen limitiert sind: „Einmal in Amt und Würden, entwickelt nicht nur der ,Monarch auf Zeit' diktatorische Führungseigenschaften und setzt seine Entscheidungen autoritär von oben nach unten durch, sondern die von den Entscheidungen betroffenen Instanzen, Interessen- und Bürgergruppen vergessen auch ihre Rechte und werden zu ,demokratischen Untertanen'“(Beck 1986: 312). 
Ein solch enges Demokratieverständnis - der moderenen westlichen repräsentativen Demokratien mit „competitive elections of political leadership for legislative and executive offices" - erscheint zunehmend ungeeinet für die Erreichung der „central ideals of democratic politics: facilitating active political involvement of the citizenry, forging political consensus through dialogue, devising and implementing public policies that ground a productive economy and healthy society, and, in more radical egalitarian versions of the democratic ideal, ensuring that all citizens benefit from the nation's wealth" (Fung/Wright 2001: 5).

Dementsprechend argumentiert auch Anne Phillips: „Demokratie heißt, dass die Menschen entscheiden, und sie bleibt eine Formalität, wenn dies nicht tatsächlich geschieht. Wir können nur davon sprechen, dass die Menschen entscheiden, wenn sie die politische Tagesordnung mitbestimmen und auf die zu treffenden Entscheidungen Einfluss haben. Die Wahl zwischen zwei Parteien, die (...) noch nicht einmal angeben, welche Pläne sie tatsächlich verfolgen, zählt nicht als Entscheidung. Menschen brauchen einen kontinuierlichen Zugang zu all jenen $\mathrm{Zu}$ sammenhängen - innerhalb der politischen Parteien und außerhalb, auf nationaler, regionaler und kommunaler Ebene - in denen sie an Entscheidungen mitwirken können (...). Aber Demokratie heißt auch, dass alle Menschen als Gleiche betrachtet werden und nicht an Bedeutung gewinnen, wenn sie mehr Versammlungen besuchen“ (Phillips 1995: 263). „Demokratische Gleichheit kann [daher] eigentlich nur bedeuten, dass eine Gesellschaft ihre ,letztgültigen' Entscheidungen einem Forum überlassen muss, an dem alle teilhaben können" (ebd.: 265).

Dennoch ist Demokratie „not an all-or-nothing-affair, but a matter of degree, societies can vary in both the extent and the intensity of their commitment to democratic practice” (Young 2000: 5). „Democracy fits on a sliding scale. More is always better, but that does not mean that we should not appreciate modest gains, understanding them as windows of insight into better possibilities" (Abers 2000: 19). Demokratie ist „das Beste, was wir haben, aber es kann sicher bessere Demokratien geben. Wenn es aber bessere Demokratien geben kann, ist dies Anlass sich immer wieder mit demokratischen Systemen auseinanderzusetzen, sie einer Bestandsaufnahme zu unterziehen und nach Reformmöglichkeiten, nach Verbesserungen zu fragen" (Massing/ Breit 2001:7).

Davon war schon John Dewey Anfang des 20. Jahrhunderts überzeugt: „We have every reason to think that whatever changes may take place in existing democratic machinery, they will be of a sort to make the interest of the public a more supreme guide and criterion of governmental activity, and to enable the public to form and manifest its purposes still more authoritatively. In this sense the cure for the ailments of democracy is more democracy" (Dewey 1927/1991: 146). Das Heilmittel mehr Demokratie gegen die Schwächen der Demokratie sieht Dewey jedoch nur als insofern geeignet, als darunter nicht verstanden wer- 
den darf, ,that the evils may be remedied by introducing more machinery of the same kind as that which already exists, or by refining and perfecting that machinery" (ebd.: 144).

Gehe ich also davon aus, dass Demokratie an sich eine gute Sache ist, dann ist wohl mehr Demokratie noch eine bessere Sache und die „Zukunft der Demokratie (...) in der starken Demokratie“ (Barber 1994: 146) zu finden. Da Demokratie freilich mehr bedeuten sollte, als die Möglichkeit, regelmäßig zur Wahl zu gehen oder das Recht auf eine Kandidatur, muss sie mehr Partizipation und echte Offenheit einschließen (vgl. Phillips 1995: 163).

\subsubsection{Demokratisierung}

Demokratisierung wurde während der bürgerlichen Revolutionen des 19. Jahrhunderts zu einem zentralen politischen Kampfbegriff, unter dem zu jener Zeit vor allem die politische Forderung eines freien und gleichen Wahlrechts verstanden wurde, ,angewandt gegenüber dem umfassenderen Begriff der Emanzipation“"(Alemann 1975: 14).

In den 70er Jahren des 20. Jahrhunderts wurde eine „zweite Krise der Partizipation konstatiert" (ebd.: 15) und der Begriff Demokratisierung wieder zu einem Schlüsselwort „politischer Frontenbildung“ (ebd.: 13): „Demokratisierung - ein Schlüsselbegriff unserer Tage" (Dettling 1974: 8). Den Bestrebungen, diesen Begriff, der „fast alles meinen“ (ebd.: 8) kann, theoretisch fassbar zu machen, entstammen die bis heute weitgehend verwendeten und zitierten Definitionen:

Demokratisierung ist nach Ulrich von Alemann ein „Mittel der Erweiterung von traditionellen Teilhaberechten an Entscheidungen im poltisch-gesellschaftlichwirtschaftlichen Raum“ (Alemann 1975: 21). Demokratisierung bezeichnet die Einführung und den Ausbau von Einflussnahme-, Beteiligungs- und Mitwirkungsmöglichkeiten an politischen Entscheidungen ebenso wie die Veränderung von bestehenden Macht- und Kräfteverhältnissen und gilt als „Versuch der Aufhebung von Ungleichheiten in der politischen Entscheidungskompetenz und in den ökonomischen Bedingungen" (ebd.: 14).

Zumeist werden neben dem Begriff Demokratisierung - zum Teil synonym, zum Teil differenziert - die Begriffe Partizipation und Mitbestimmung verwendet. Diese drei Termini können „kaum als Eigenwert, sondern nur als Mittel oder Form zur Realisierung bestimmter Ziele oder Werte, [wie beispielsweise] die ,reale', ,gesamtgesellschaftliche Demokratie', ,Mündigkeit', ,Gleichheit', ,Emanzipation' oder ,Humanität', gesehen werden“" (ebd.: 17). Zur Unterscheidung der drei Begriffe führt Alemann eine Abstufung ein, wonach unter Mitbestimmung mit Fokus auf „Mit-“ eine „nicht wirklich ausschlaggebende Mitwirkung, Mitverwaltung, Beteiligung"verstanden wird. Partizipation definiert er als ausgeweitetes „Teilhaben vieler an Entscheidungen“. Und Demokratisierung 
als am weitesten gehende Form sieht er schließlich als ein „Mittel zur Realisierung gesamtgesellschaftlicher Selbstbestimmung" (ebd.: 18) und zur Realisierung eines Maximums an gesellschaftlicher Mitbestimmung in allen Teilbereichen. Ziel ist eine möglichst optimale Beteiligung von Bürgerinnen und Bürgern an politischen Entscheidungsprozessen und Aktivitäten. Auch Sherry Arnstein betont den Unterscheid zwischen Mitbestimmung im Sinne einer Beteiligung von Bürgerinnen und Bürgern als harmloser Euphemismus und Demokratisierung als Begriff für Macht oder Herrschaft der Bürgerinnen und Bürger. Dies impliziert jedenfalls eine Umverteilung „of power that enables the have-not citizens, presently excluded from the political and economic processes, to be deliberately included in the future. It is the strategy by which the have-nots join in determining how information is shared, goals and policies are set, tax resources are allocated, programs are operated, and benefits like contracts and patronage are parcelled out" (Arnstein 1967: 216).

Norbert Elias verwendet für eine Definition von Demokratisierung gar den Begriff der funktionalen Demokratisierung, die - wie er konstatiert - nicht zwangsweise identisch mit der Hervorbringung einer institutionellen Demokratie sein muss. Vielmehr bezieht sich der Terminus funktionale Demokratisierung auf „die Veränderung der gesellschaftlichen Machtverteilung, die ihren Ausdruck zeitweilig in verschiedenen Institutionsformen finden kann" (Elias 1970: 72), hierbei sollen Machtdifferentiale zwischen den Menschen verringert und Machtgewichte gleichmäßiger unter den Menschen verteilt werden (vgl. ebd.: 73). „Demokratisierung läuft in diesem Sinne (...) jedenfalls auf eine Ausdifferenzierung von Mitsprachen, Kontrollen und Widerstandsmöglichkeiten hinaus" (Beck 1986: 314), deren oberstes Ziel eine gesellschaftliche Emanzipation sein soll (vgl. Alemann 1975: 18).

Demokratisierung wird als „dynamisches Phänomen“ verstanden, als ein „Prozess der Übertragung demokratischer Prinzipien“ (Siegelkow 1975: 118), wobei die Forderung nach Demokratisierung jedenfalls über das Modell einer modernen repräsentativen Demokratie mit periodischen Wahlen hinausgeht und mehr ist ,als nur die Installierung eines Abstimmungsmodus zur Entscheidungsfindung" (Kurswechsel 2003: 5). Demokratisierung soll nicht heißen, eine Gesellschaft nur ,nach innen in immer weiteren Bereichen dem Prinzip von Wahlen, Repräsentation und demokratischer Entscheidungsfindung zu unterwerfen“ da dies zwar bedeutet, dass die ,gesellschaftliche Eingriffstiefe von Herrschaft zunimmt, unsere Möglichkeiten uns zu entziehen und zu verhandeln aber sinkt. Mehrheitsentscheidungen garantieren an sich keine Freiheit und Gleichheit" (Spehr 2003: 98). So führte beispielsweise auch das Frauenwahlrecht nicht automatisch zu einer politischen Gleichberechtigung von Frauen, ,ja nicht einmal zu einer adäquaten qualitativen Repräsentation und Beteiligung von Frauen in den etablierten politischen Institutionen“" (Sauer 2001: 171). 
Ist also Demokratie - in Anlehnung an Massing und Breit (2001: 7) - das Beste, was wir haben, jedoch immer verbesserungswürdig und kann, wenn Demokratie eine gute Sache ist, mehr Demokratie noch eine bessere Sache sein, dann könnte Demokratisierung, im Sinne einer möglichst optimalen Beteiligung von Bürgerinnen und Bürgern an politischen Entscheidungsprozessen und Aktivitäten (vgl. Alemann 1975: 18), ein Mittel zu deren Verbesserung sein: Demokratisierung als Heilmittel der Demokratie würde demgemäß bedeuten, dass die bestehenden Macht- und Kräfteverhältnisse gleichmäßiger unter den Menschen verteilt werden und Ungleichheiten in der politischen Entscheidungskompetenz sowie in den ökonomischen Bedingungen aufgehoben werden. 


\section{Budgets und die Forderung nach Demokratisierung der Finanz- und Wirtschaftspolitik}

Die Wirtschaftspolitik und als ihr Teilbereich die Finanzpolitik sind „Kernelemente staatlichen Handelns“ (BEIGEWUM 2002: 9). Traditionell werden diese in repräsentativen Demokratien als dem Staat vorbehaltene Aktivitäten verstanden und deshalb von weitgehenden Einflussnahme-, Beteiligungs- und Mitwirkungsmöglichkeiten durch Bürgerinnen und Bürger und einer demokratischen Diskussion abgeschirmt. Dies basiert auf zwei Annahmen: Zum einen wird Wirtschaftspolitik als ein neutrales Instrument ohne jegliche soziale und geschlechtsspezifisch unterschiedliche Auswirkungen dargestellt und zum anderen wird sie zumeist als diffizile technische Angelegenheit wahrgenommen, die besser den „ExpertInnen“ überlassen werden soll (vgl. Cagatay et al 2000: 2). Die hohe Komplexität von Wirtschaftspolitik impliziere, dass sie nur ein ganz bestimmtes - geringes - Ausmaß an Demokratisierung zuließe. Denn ,die Bevölkerung müsse vielfach vom Entscheidungsprozess ausgeschlossen werden, da sie zu wenig wisse, gar kein Interesse an Mitbestimmung habe oder bestimmte Gruppeninteressen verfolge, die sich gegen die Allgemeinheit richten oder einfach weil sie Gerechtigkeitsfragen mit Effizienzproblemen vermenge" (Scherz 2001: 79f). In Folge dessen ist ,in all societies, democratic or otherwise, budget preparation (...) almost an exclusive prerogative of the executive. The legislature sometimes participates, but generally towards the very end of the process and with varying degrees of influence. The wider public, however, has remained virtually excluded" (Osmani 2002: 231).

Abgesehen davon bedeuten Forderungen nach Demokratisierung von Wirtschaftspolitik, „wenn man wisse, was eine optimale Wirtschaftspolitik sei, (...) nur eine Gefährdung" (Scherz 2001: 80). Daher konzentriert sich in den modernen westlichen Demokratien der Budgeterstellungsprozess größtenteils in den Händen von Finanzministern. Isabella Bakker weist gar darauf hin, dass zum Teil auch gewählte RespräsentantInnen aus dem Prozess ausgeschlossen sind, resulting in a ,democratic deficit' concerning the making of the most fundamental economic policies" (Bakker 2002: 5). Hieraus ergibt sich eine Mystifizierung von Wirtschaftspolitik „als scheinbar neutral und nur Sachzwängen“ (Brangsch 2003: 1) unterworfen. Das grundsätzliche Charakteristikum von Wirtschaftspolitik in den modernen westlichen Demokratien ist also die gestiegene Bedeutung der Urteile von „technokratischen Experten“. Wirtschaftspolitik „reflektiert vorgeblich objektive Notwendigkeiten und Eliten suggerieren, dass es Optimalität in der Wirtschaftspolitik geben könne" (Scherz 2001: 81). Insofern ist es wenig verwunderlich, dass gerade die Wirtschaftspolitik und als einer ihrer Teilbereiche die Finanzpolitik weitgehend demokratiefreie Bereiche darstellen. 
Gerade die Unterstreichung des Technischen birgt eine Tarnung der sozialen Inhalte von Wirtschafts- und Finanzpolitik und lässt sie kontextlos erscheinen. Vielmehr jedoch erfüllen Wirtschaftspolitik und entsprechend Budgets traditionell eine Vielzahl an zentralen wirtschaftlichen und sozialen Funktionen: „they allocate resources, provide basic social services, ameliorate income and wealth disparities, stabilize prices, and generate economic growth and employment" (Cagatay et al 2000: 13).

Das Budget „stellt die finanzielle Grundlage dar, auf der sich das Regierungshandeln aufbaut" (Blankart 2003: 432) und ist das „finanzielle Abbild des jeweiligen politischen Programms“ (Zimmermann/Henke 2001: 61). Im Wesentlichen ist das Budget in repräsentativen Demokratien ein Dokument, das - nachdem von der Legislative genehmigt - die Regierung autorisiert, Einnahmen und Ausgaben zu tätigen um bestimmte Ziele zu erreichen, also festlegt, wie die Regierung öffentliche Gelder aufbringt und diese verteilt. Im Budget werden die „staatlichen Ausgabenvorhaben den erwarteten Einnahmen gegenübergestellt und vollzugsverbindlich beschlossen" (Blankart 2003: 431), wobei alle Aktivitäten des Staates, die mit Geldflüssen verbunden sind ihren Ausdruck im Budget finden (vgl. BEIGEWUM 2002: 57). „Since the budget determines the origin and application of public financial resources, it plays a central role in the process of government, fulfilling economic, political, social, legal and administrative functions" (Norton/Elson 2002: 5).

Diese Funktionen beschreibt Ewald Nowotny folgendermaßen: Das Budget erfüllt eine politische Funktion indem es Instrument der Regierung zur Erfüllung ihrer Aufgaben ist, eine Ordnungsfunktion, da es zur Planung und Durchführung staatlicher Aktivitäten dient, eine finanzwirtschaftliche Funktion zur Zuweisung von Mitteln an die Verwaltung und eine Kontrollfunktion - es ermöglicht der Legislative die Exekutive zu kontrollieren (vgl. Nowotny 1999: 175). Dementsprechend erfüllt das Budget auch gesellschaftspolitische Lenkungs- und Verteilungsfunktionen, Finanzpolitik ist ,in Zahlen gegossene Gesellschaftspolitik" (BEIGEWUM 2002: 12).

Das Budget kann demgemäß als ein wesentliches Dokument staatlichen Wirtschaftens und staatlicher Wirtschaftspolitik bezeichnet werden, es ist eine entscheidende, wenn nicht die zentralste Komponente von Wirtschaftspolitik: „Budget is one of the most important economic tools available at the disposal of governments" (Osmani 2002: 231). Finanzpolitik ,ist ein Teil der Wirtschaftspolitik - und zwar einer ihrer zentralsten" (BEIGEWUM 2002: 10). Mittels Budgets werden „entscheidende Weichenstellungen betreffend [der] Ausrichtung der Wirtschaftspolitik und [der] Verteilung von Ressourcen getroffen" (BEIGEWUM 2002: 14).

Wirtschaftspolitik spiegelt auch immer die Interessen dominierender gesellschaftlicher Gruppen wider und in diesem Sinne ein bestimmtes gesellschaft- 
liches Kräfteverhältnis und produziert eine Vielzahl „of social outcomes by determining which groups get what out of the economic pie" (Cagatay et al 2000: 2). Dementsprechend ist gerade das Budget „one of the most important arenas of decision-making in which the potentially conflicting interests of different groups of the society have to be confronted with each other. This is true about every aspect of budget formulation, the most obvious case being that of allocation of public expenditure. Any decision on the pattern of allocation necessarily involves a decision as to whose interests are to be given precedence over the interests of others" (Osmani 2002: 232). Budgets reflektieren demgemäß die ökonomischen, sozialen und gesellschaftlichen Prioritäten eines Staates und bilden so die Machtverhältnisse einer Gesellschaft ab (vgl. BEIGEWUM 2002: 12): „Seclusion stifles voice and secrecy dilutes accountability - together, they open the way for abuse of power, whose victims are generally the most vulnerable groups in the society" (Osmani 2002: 231).

Finanzpolitik ist „ein Unterfangen bestenfalls für die Bevölkerung, zumeist gegen die Bevölkerung und fast nie ein Projekt von der Bevölkerung" (Scherz 2001: 81). Dies gilt nicht nur für Staaten ohne verankerte demokratische Strukturen, sondern auch für westliche repräsentative Demokratien, in denen die Legislative dafür verantwortlich wäre, die Interessen der Bürgerinnen und Bürger im Budgeterstellungsprozess zu vertreten, „, but in practice it often turns out to be a very poor substitute of direct voice. It is the rich and the powerful who manage to represent their interests better. Unless this state of affairs is fundamentally altered so that the poor and the marginalized groups can have a better voice in the budgetary process, the development process will continue to remain unjust" (Osmani 2002: 233). Auch wenn finanzpolitische Entscheidungsfindung nicht zwangsweise geheim gehalten werden und so tendieren trotzdem ,powerful interest groups connected to rich elite (...) to dominate the setting of priorities, winning tax concessions, and expenditure, on programmes important to them" (Elson 2004: 16f).

Zusammenfassend besteht also ein massives Demokratiedefizit von Finanz- und Wirtschaftspolitik, genauer formuliert: ein zweifaches Defizit, nämlich ein Legitimations- und ein Partizipationsdefizit. Als Reaktion auf diese - auf das ,prevailing lack of transparency, accountability and democratization in policy-making" (Cagatay/Ertürk 2004: 44) - werden immer mehr Forderungen nach einer Demokratisierung von Wirtschaftspolitik laut. Denn ,einer demokratischen Willensbildung soll eine stärkere Rolle in der wirtschaftspolitischen Entscheidungsfindung zugewiesen werden und in der Wirtschaftspolitik sollen Gerechtigkeitsüberlegungen in den Mittelpunkt gerückt werden” (Scherz 2001: 79).

Da die ,praktizierte Wirtschaftspolitik (...) so komplex nicht“ (ebd.: 82) ist, darf es bei einer Demokratisierung von Wirtschaftspolitik nicht darum gehen, neue technische und ebenso komplexe Möglichkeiten des Budgets und des Budget- 
erstellungsprozesses zu entwickeln, ebenso wenig wie bestehende zu perfektionieren $^{12}$, sondern vielmehr darum, dass Budgets und Wirtschaftspolitik im Allgemeinen nicht mehr als ausschließlich ExpertInnen verständliche Angelegenheiten und "completely beyond the reach of ordinary citizens" (Cagatay et al 2000: 11) gesehen werden. Dies bedarf der „creation of fiscal democracy, a system in which budget processes are transparent, accountable and participatory; and in which every type of citizen had equal voice" (Elson 2004: 16) mit dem Ziel „of widening governance and accountability structures by giving voice to those previously marginalized from fiscal policy decision-making“ (Bakker 2002: 12) und im Zuge dessen auch mit dem Ziel ,of influencing policy to better fulfill the rights of disadvantaged groups" (Norton/Elson 2002: 35).

In den Mittelpunkt von wirtschafts- und finanzpolitischen Entscheidungen müssen die Menschen - der Demos - ebenso wie die Auswirkungen von Finanzund Wirtschaftspolitik auf die Menschen gebracht werden, denn ,all macroeconomic policies have a social content as they are enacted within a certain set of distributive relations and institutional structures; and that all macroeconomic policies produce a variety of social outcomes" (Cagatay et al 2000: 10). Die Menschen müssen eine Möglichkeit der Einflussnahme, Beteiligung und Mitwirkung und eine Stimme in wirtschaftspolitischen Entscheidungsprozessen bekommen, „Fragen der Prioritätensetzung“ in der Finanzpolitik und „der Konsequenzen politischer Entscheidungen müssen einer breiten Bevölkerung zugänglich gemacht werden" (BEIGEWUM 2002: 19). Ziel ist, dass die Wirtschaftspolitik als „res publica“ und nicht länger als Privatbesitz herrschender Eliten, sondern vielmehr als „eine öffentliche Sache, die allen gehört und alle angeht“ (Novy 2003: 12) verstanden wird.

Bei einer solchen ,people-centred“ Wirtschaftspolitik geht es dementsprechend um zweierlei: Sowohl die Inhalte von Wirtschaftspolitik als auch die Entstehungsprozesse wirtschaftspolitischer Entscheidungen müssen demokratisiert werden - wie in Kapitel 2.4.2 herausgearbeitet - im Sinne einer Realisierung eines Maximums an Mitbestimmung mit dem Ziel eine möglichst optimale Beteiligung von Bürgerinnen und Bürgern an den wirtschaftspolitischen Entscheidungsprozessen und Aktivitäten sowie einer Veränderung der gesellschaftlichen Machtverteilungen zu erreichen. Denn die Kernelemente einer Demokratisierung (von Finanz- und Wirtschaftspolitik) sollen die „Stärkung bislang subalterne Bevölkerungsgruppen in politischen Diskussions- und Entscheidungsprozessen und die Ausweitung der Demokratisierung in Richtung auf die Machtkerne der jeweiligen Gesellschaftsformen“ (Becker 200lb: 102) sein. Rebecca Abers konkretisiert dies wie folgt: Demokratisierung ermöglicht denjenigen, die bis jetzt von politischen Entscheidungsprozessen ausgeschlossen

12 siehe dazu die Ausführungen zu John Dewey in Kapitel 2.4.1. 
waren Einflussnahme und Mitbestimmung. Ziel ist nicht die Diskussion der Implementierung vordesignter Programme, sondern vielmehr die Diskussion politischer Regierungsagenden, Ziele und Programme. Dies ,involves effective citizen control, through which those who participate have real deliberative power" (Abers 2000: 7).

Teil des Anliegens Wirtschaftspolitik zu demokratisieren, ist das Budget als zentrale Komponente der Wirtschaftspolitik und „materiellen Kern des Staates“ (Novy/Leubolt 2004: 19) transparenter und partizipativer zu gestalten. Denn „scrutinizing public budgets is an important step towards understanding the social content of macroeconomic policies currently in place and democratizing the process of macroeconomic policy-making" (Cagatay et al 2000: $2 \mathrm{f}$ ). Gerade vor dem Hintergrund, dass Demokratisierung einen Versuch ,der Aufhebung von Ungleichheiten in der politischen Entscheidungskompetenz und in den ökonomischen Bedingungen" (Alemann 1975: 14) darstellt, erweist sich das Budget als zentrales wirtschaftspolitisches Instrument der Verteilung, Steuerung und Kontrolle als logischer Anknüpfungspunkt für eine Demokratisierung von Wirtschaftspolitik und einer dementsprechenden Veränderung der gegenwärtigen Macht- und Eigentumsverhältnisse.

Von diesen Ausführungen ausgehend sollten für eine Demokratisierung der Finanz- und Wirtschaftspolitik meiner Meinung nach zumindest drei Dimensionen beachtet werden: Zunächst geht es um den ,politisch-demokratischen Input ${ }^{\text {"13 }}$ (Sauer 2001: 174), oft auch als politics-Dimension bezeichnet, also um die „Eingabeseite der politischen Prozesse“, um „die Vorgänge und die Wertigkeit der Willensbildung und Entscheidungsfindung in der Demokratie" (Schmidt 2000: 294f), die „für jede Demokratisierung der Demokratie absolut unverzichtbar ist" (Holland-Cunz 1999: 87). Hierbei handelt es sich um die Chancen möglichst optimaler und gleichberechtigter Beteiligung von Bürgerinnen und Bürgern an wirtschaftspolitischen Entscheidungsprozessen und Aktivitäten.

13 Die politikwissenschaftliche Unterscheidung zwischen politisch-demokratischen Input und Output muss deutlich von der Input- und Outputorientierung in der Finanzwirtschaft abgegrenzt werden. Input- und Outputorientierung in der Finanzwirtschaft beschreiben jeweils eine Art und Weise der Budgetplanung beziehungsweise einen Steuerungsansatz der Budgeterstellung. Während beim „Denken in Inputs“ (Zimmermann/Henke 2001: 90) über den Mitteleinsatz (wie beispielsweise Personal- oder Sachmittel) geplant wird, stehen bei der Outputorientierung die „Ziele des jeweiligen politischen Bereichs, die in Form von zu erstellenden Leistungen zu konkretisieren sind" (ebd.). Im Zuge aktueller Bestrebungen von Verwaltungsreformen und New Public Management wird dieser Steuerungsansatz zunehmend von der bisher vorherrschenden Inputsteuerung zu einer ziel- und outputorientierte Steuerung verlagert, da dies als Voraussetzung für eine Steigerung der Effizienz und Effektivität des öffentlichen Sektors gilt (vgl. u.a. Schedler/Proeller 2006: 56, Reichard 1994:135f, kritisch dazu und einen Zusammenhang zu Gender Budgeting herstellend auch Sharp 2003). 
Dieser partizipative Input-Aspekt muss mit dem ,institutionellen ${ }^{14}$ Setting [wirtschafts- und finanz-] politischer Willensbildungs- und Entscheidungsprozesse" (Sauer 2001: 175), also der Ausgestaltung demokratisch-institutioneller Arrangements und Bedingungen aufgrund derer eine Beteilung der Bürgerinnen und Bürger erst möglich wird, verknüpft werden.

Des Weiteren zielt eine Demokratisierung der Wirtschaftspolitik auf die Inhalte von Wirtschaftspolitik ab, in die Gerechtigkeitsüberlegungen einfließen sollen, und damit auf den „Output der Leistungsfähigkeit politischer Organe“ (ebd.), die so genannte policy-Dimension, also auf die „Produktionsseite“ (Schmidt 2000: 294) politischer Prozesse und die „Qualität des Regierens oder der politischen Steuerung" (ebd.: 295).

Eine Demokratisierung der Finanz- und Wirtschaftspolitik verstehe ich demgemäß sowohl als input-output-orientiert als auch als institutionenzentriert.

14 Sowohl die Ökonomie als auch die Politikwissenschaft verfügt jeweils über einen Institutionenbegriff und eine Wissenschaftsbewegung des Institutionalismus sowie des Neo-Institutionalismus (Politikwissenschaft) beziehungsweise der Neuen Institutionellen Ökonomie (Ökonomie) in den letzten Jahrzehnten. In der Ökonomie wird davon ausgegangen, dass Institutionen Regelsysteme sind, in denen Verhaltensweisen geregelt, Aktionen in Interaktionen kanalisiert und Interaktionen strukturiert werden, also formelle wie informelle Verhaltensregeln darstellen (vgl. Homann/Suchanek 2005: 22 und 102ff). „Leitgedanke der Institutionalisten ist die Überzeugung, dass die jeweils vorherrschenden Institutionen gesellschaftliche Aktivitäten kanalisieren und prädisponieren" (Reuter 1998: 62). Die Politikwissenschaft differenziert im Unterschied dazu zwischen Institutionen im Weiteren und im engeren Sinn: Institutionen in einem weiteren Sinne werden ähnlich dem ökonomischen Verständnis von Institutionen als informelle und formalisierte Handlungsregeln oder Spielregeln, die die passenden Aktionen in Bezug auf Rollen und Situationen definieren (vgl. Sauer 2001: 91, Leftwich 2004: 10). Institutionen in diesem Verständnis sind ,the rules of the game of society or, more formally, the human devised constraints that shape human interaction" (North 1990: 3). Formelle Institutionen sind charakterisiert „by the rules and regulations constituting and governing the conduct of organizations (...) all of which shape and constrain human behaviour and interaction within them. Informal institutions, on the other hand, may be understood in a much looser way as the customs, norms of behaviour" (Leftwich 2004: 10f). In einem engeren Sinn stellen politische Institutionen die expliziten Regeln und Prozesse im politischen Handlungsfeld dar: Unter politischen Institutionen werden ,in mehr oder weniger traditioneller Weise formale Organisationen" verstanden, „die den Prozess der politischen Handlungskoordination - der Meinungsbildung, Konfliktaustragung, Konsensbildung, Entscheidungsfindung und des Entscheidungsvollzugs - strukturieren" (Seibel 1997: 362).

Ich verstehe im Folgenden den Term Institution in Anlehnung an den politikwissenschaftlichen Diskurs in diesem engeren Sinn als politisch-demokratische Institution, die demokratische Entscheidungsfindungsprozesse kanalisiert und strukturiert. 


\subsection{Fallbeispiel Budgetinitiative zur Demokratisierung der Wirt- schaftspolitik: PB - Participatory Budgeting ${ }^{15}$}

Im Laufe der letzten Jahrzehnte haben sich in einer Reihe von Ländern BudgetInitiativen mit dem Ziel eine Demokratisierung der Wirtschaftspolitik zu forcieren entwickelt. Exemplarisch möchte ich die vielfältigen Ansätze und Erfahrungen wie eine Demokratisierung von Wirtschaftspolitik erwirkt werden kann in diesem Kapitel anhand des Participatory Budgeting in Porto Algere, Brasilien, darstellen. Der Begriff Partizipatives Budget bezeichnet grundsätzlich einen Beteiligungs- und Mitbestimmungsprozess von Bürgerinnen und Bürgern am Budget, ,giving citizens direct choice and decisionmaking power in determining allocations within a budget” (Norton/Elson 2002: 42). „Participatory Budgeting was intended as a means to help poorer citizens and neighbourhoods receive greater levels of public spending” (Wampler 2000: 3). Und „Participatory Budgeting programs are part of a larger effort (...) to extend and deepen actual, existing democracy" (ebd.: 2). Für die erste derartige Demokratisierungsinitiative der Budgeterstellung wurde die Hauptstadt des südlichsten brasilianischen Bundesstaates Rio Grande do Sul, Porto Alegre, bekannt. Obgleich zwar umstritten ist inwieweit in Porto Alegre tatsächlich das allererste Partizipative Budget erstellt wurde, so wurde dort doch die bekannteste Initiative gestartet: „Porto Alegre's PB is probably one of the most successful practices of participatory democracy“" (Santos 2005: 313) und hat seit ihrem Beginn im Jahr 1989 weltweit andere Initiativen ${ }^{16}$ angeregt und beeinflusst.

\subsubsection{Hintergrund und Entstehungszusammenhang des Partizipativen Budgets}

In Porto Alegre entstanden schon während Brasiliens Militärdiktatur vor allem in den 1970er Jahren starke soziale zivilgesellschaftliche "Lokalinitiativen“ (Becker 2001a: 3) - so genannte „city's grassroots organizations“" (Santos 2005: 314) - vor allem in den Armenvierteln, die mehr Mitsprache und verbesserte Le-

15 Der ursprüngliche - portugiesische - Terminus für Participatory Budgeting ist Orçamento Participativo, im deutschsprachigen Raum wird dies zumeist mit „Partizipatives Budget“ übersetzt. Diesen eingedeutschten Begriff werde auch ich in weiterer Folge der Verständlichkeit halber verwenden.

16 Zwischen 1997 und 2000 wurden Partizipative Budgets in verschiedenster Form in über 140 brasilianischen Städten und sechs Staaten implementiert (vgl. Avritzer/Santos 2003: 18 und Norton/Elson 2002: 42) Im Jahr 2004 zählte Daniel Schugurensky gar 194 Initiativen alleine in Brasilen und berichtete von Experimenten mit Partizipativen Budgets in Buenos Aires, Rio Cuarto und Rosario in Argentinien, in Montevideo in Uruguay ebenso wie in Städten Perus, Ecuadors, Mexikos, Kolumbiens und El Salvadors. Weitere PB Initiativen finden sich in Afrika, Asien ebenso wie in Europa und auch in Kanada (vgl. Schugurensky 2004: 4) 
bensbedingungen forderten ebenso wie „Investitionen in die städtische Infrastruktur und Leistungen sowie die Autonomie der Stadtteilinitiativen" (Novy/ Leubolt 2004: 8). Diese zivilgesellschaftliche Tradition wurde auch während des Prozesses der Einführung repräsentativdemokratischer Strukturen nach dem Ende der Militärdiktatur 1985 weiterhin forciert. Anfang der 1980er Jahre wurde im Zuge der zahlreichen sozialen Bewegungen ein Dachverband der Lokalinitiativen (UAMPA) gegründet, der zum einen die sozialen Bewegungen mit ihren Forderungen nach einer Demokratisierung, die über eine bloße Einführung einer repräsentativen Demokratie nach amerikanisch-europäischen Vorbild hinausgehen sollte, stärken wollte. Zum anderen forderte UAMPA ,for the first time the right to participate in the deliberation on budget issues at the local level in 1986“ (Avritzer 2002: o.S.). So wurde bei einer Sitzung dieses Dachverbandes im März 1986 folgendes festgehalten: „the most important element in city politics is the definition on where the resources will be applied. That is the reason why neighbourhood associations should seek to directly influence in the elaboration of the city budget" (UAMPA 1986 zit. in Avritzer o.J: 8).

Im Zuge des Wahlkampfes im Jahre 1988 wurden die Forderungen nach Demokratisierung der Lokalpolitik auch vom Bürgermeisterkandidaten der Arbeiterpartei (Partidondos Trabalhadores - PT) übernommen, der ankündigte „eine Umkehr der Verteilungsprioritäten von öffentlichen Mitteln hin zu den gesellschaftlich marginalisierten Gruppen" (Leubolt 2003: 46) forcieren zu wollen. Die Lokalinitiativen unterstützen diesen Kandidaten, er gewann im Jänner 1989 die Wahl und die neu gewählte PT-Stadtregierung initiierte ,eine neue Form der Budgeterstellung, das partizipative Budget" (Becker 2001a: 3), mit dessen Hilfe die angekündigte Demokratisierung der Lokalpolitik ermöglicht werden sollte (vgl. Novy/Leubolt 2004: 9). „It was based on an institutional innovation aimed at guaranteeing popular participation in preparing and carrying out the municipal budget, hence, in the distribution of resources and the definition of investment priorities“" (Santos 2005: 314).

Die Entstehung des Partizipativen Budgets war das Resultat des brasilianischen Demokratisierungsprozesses ,as well of its impact in the country's region which developed the most democratic tradition. It took advantage of the new legislation which emerged in the constitution-making process as well as of the productive overlapping of a tradition of democratic associations in the South with a specific proposal for participation" (Avritzer 2002: o.S.). Das Partizipative Budget beruhte im Allgemeinen auf der Zurückweisung der Vorstellung einer repräsentativen Demokratie als einzige Form der Demokratie und gleichzeitigem Vertrauen auf alternative partizipative ebenso wie deliberative Demokratieformen, der pragmatischen Konzeption von Verbindungen direktdemokratischer und repräsentativdemokratischer Elemente mit dem Fokus auf eine Umverteilung "based on a new equation between participation and social benefit" 
(Santos 2005: 313). Es ging bei der Entstehung des partizipativen Budgets in Porto Alegre jedenfalls nicht ,um die Einführung eines damals schon fertig ausgearbeiteten Konzepts, sondern vielmehr um die durchaus konfliktive, schrittweise Institutionalisierung der Teilhabe der Bevölkerung am Lokalstaat, unter laufender Evaluierung und Veränderung des Prozesses seitens seiner Beteiligten“ (Leubolt 2003: 45).

\subsubsection{Definition, Funktionsweisen und Zielsetzungen des Partizipativen Budgets}

Das Partizipative Budget wird definiert als ,a local practice of public deliberation on budget issues" (Avritzer 2002: o.S.), ,which responds to the plight of the poor" (Avritzer o.J: 10) und kann laut Leonardo Avritzer durch vier Elemente charakterisiert werden:

Das erste Element stellt die Delegation der lokalen Souveränität von gewählten politischen Vertreterinnen und Vertretern auf eine Reihe von regionalen und thematischen BürgerInnenversammlungen, an denen jede/ $r$ wahlberechtigte BürgerIn teilnahme-, rede- und stimmberechtigt ist, dar. Das zweite Charakteristikum ist die Kombination von direkten und indirekten Demokratietraditionen, die Kombination von repräsentativen und partizipativen Demokratiemodellen. Das Partizipative Budget ,includes social actors, neighbourhood association members and common citizens in a process of negotiation and deliberation which takes place in two stages: a participatory stage, in which participation is direct, and a representative stage, in which participation takes place through the election of delegates and/or councillors" (ebd.). Drittens werden im Zuge des Prinzips der Selbststeuerung die Regeln der Teilhabe am Prozess der Erstellung des Partizipativen Budgets von den Teilnehmenden selbst bestimmt und können jährlich adaptiert oder verändert werden. Das vierte Element ist der Versuch die Prioritäten, nach denen öffentliche Mittel verteilt werden, auf Basis einer Kombination aus Partizipation und technischen Entscheidungskriterium umzukehren, vor allem zugunsten bislang benachteiligter gesellschaftlicher Gruppen (vgl. Avritzer 2002: o.S.).

Ähnlich identifiziert auch Boaventura de Sousa Santos drei wesentliche Prinzipien des Partizipativen Budgets: Erstens sind alle Bürgerinnen und Bürger gleichberechtigt teilnahmeberechtigt, es gibt keine Privilegierten - auch „community organizations have no special status" (Santos 2005: 316). Zweitens funktioniert die Partizipation über eine Kombination von Regeln der direkten und der repräsentativen Demokratie in geregelten Institutionen, deren interne Regeln jeweils von den Teilnehmenden selbst bestimmt werden. Und drittens passiert die Allokation der staatlichen Ausgaben anhand einer Methode, die sich sowohl aus ,.,general criteria' - substantive criteria established by the participatory institutions to define priorities - and ,technical criteria' - criteria of technical or eco- 
nomic viability as defined by the executive and federal, state, or city legal norms" (Santos 1998: o.S.) zusammensetzt. Das Partizipative Budget ist also eine Form „of public government that tries (...) resorting to the direct participation of the population in the different phases of budget preparation and implementation, with special concern for the definition of priorities for the distribution of investment resources" (ebd.), wobei zu betonen ist, dass sich die Partizipation ausschließlich ,auf die Ausgabenseite des Budgets“ (Novy/Leubolt 2004:

17) bezieht.

\section{Abbildung 1: Schematische Darstellung des partizipativen Budgetprozesses}

Gewählte

Delegierte

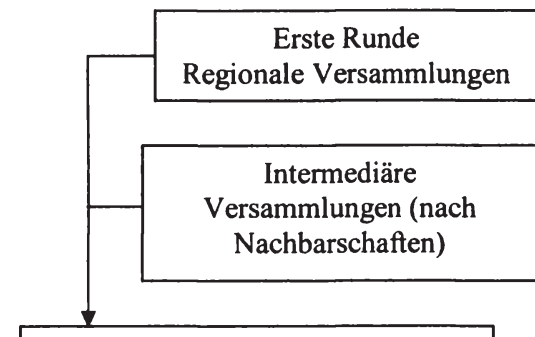

16 REGIONAL BUDGET FOREN
Gewählte

Delegierte

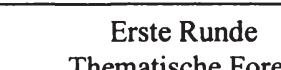

Thematische Foren

Intermediäre

Versammlungen (nach

Subthemen)

5 THEMATISCHE BUDGET FOREN

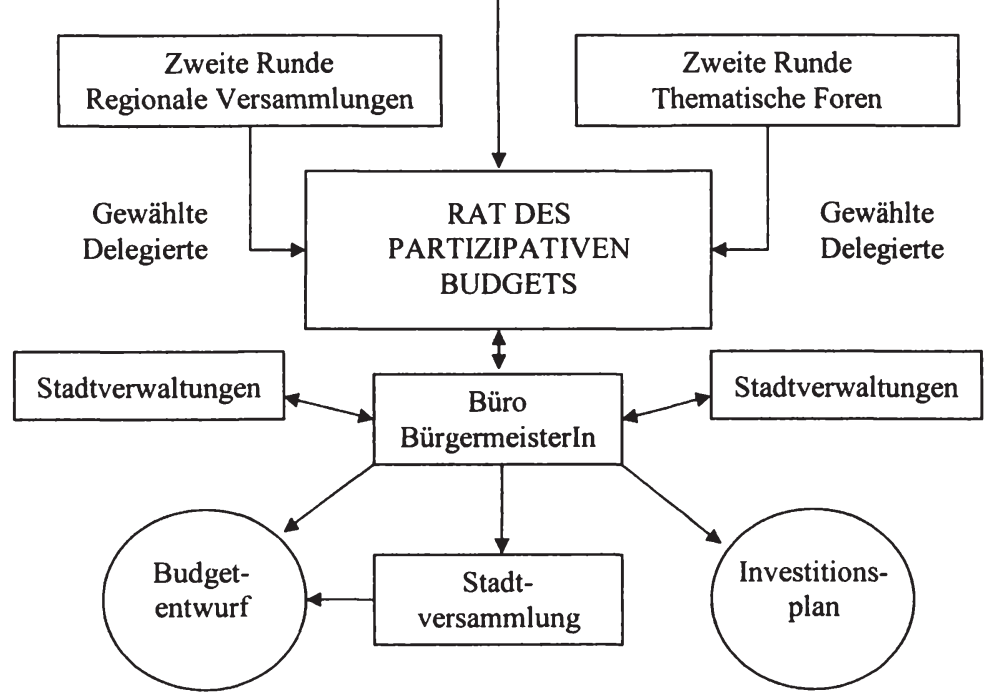

Quelle: Abers 2000: 86, eigene Übersetzung und Adaptionen 
Der tatsächliche Prozess der Budgeterstellung im Zuge des Partizipativen Budgets dauert das ganze Jahr an und stellt einen Kreislauf dar, der sich um regionale und thematische BürgerInnenversammlungen, um so genannte „Fora of Delegates" und um den Rat des Partizipativen Budgets (Conselho do Orçamento Participativo - COP) zentriert (vgl. Abbildung 1).

Der Budgeterstellungsprozess beginnt dezentral in den sechzehn Bezirken, in die Porto Alegre geteilt ist, in regionalen Versammlungen und in parallel dazu laufenden sechs thematischen Foren zu Gesundheit und Sozialem, Transport und Verkehr, Stadtentwicklung und -organisation, Erziehung und Freizeit, Kultur sowie Wirtschaftsentwicklung und Steuerpolitik (vgl. Santos 2005: 317f). Teilnahmeberechtigt an den regionalen BürgerInnenversammlungen sind alle Bürgerinnen und Bürger des jeweiligen Bezirkes, wobei all jene, die älter als sechzehn Jahre sind, auch stimmberechtigt sind. Teilnahmeberechtigt an den Themenforen sind alle, die sich für das Thema interessieren. Die BürgerInnenversammlungen und die Themenforen sind ,places for discussion and deliberation" (Avritzer 2002: o.S.).

In einer ersten Runde wird in den BürgerInnenversammlungen zunächst Rechenschaft der Stadtregierung über das laufende Haushaltsjahr abgelegt und über dieses diskutiert. Weiters werden Prioritäten für das kommende Budget definiert und gewichtete Prioritätenlisten erarbeitet ebenso wie Delegierte des $\mathrm{Be}$ zirkes gewählt, die dann in den darauf folgenden Monaten Treffen in den einzelnen Nachbarschaften des jeweiligen Bezirks abhalten und dort mögliche und notwendige Projekte diskutieren um für die zweite Runde einen regionalen Budgetvorschlag vorlegen zu können. Ziel ist eine Abstimmung der Prioritäten für den jeweiligen Bezirk, wobei die Prioritätensetzungen mit einem Punktesystem bewertet und an der Zahl der von den vorgeschlagenen Projekten betroffenen Bürgerinnen und Bürger gewichtet werden.

In der nächsten Runde der regionalen BürgerInnenversammlungen und der thematischen Foren werden die Prioritäten ratifiziert und hierarchisiert und auch Delegierte für die „Fora of Delegation“ - „collegiate organs with consulting, controlling, and mobilizing functions" (Santos 1998: o.S.) - nach einem bestimmten Schlüssel, dessen Kalkulationsbasis die EinwohnerInnenzahl darstellt, gewählt. Sie fungieren dann - ,individually or as participants in community or thematic organizations“" (Santos 2005. 318) - als Vermittelnde zwischen der Bevölkerung und dem COP.

Außerdem werden auch die Delegierten für den COP, die jeweils nur ein Mal wieder gewählt werden können von der Bevölkerung gewählt. Der COP setzt sich in Folge aus jeweils zwei Mitgliedern der sechzehn regionalen Versammlungen, zwei Mitgliedern der sechs Themenforen, jeweils einem Mitglied des UAMPA und der Gewerkschaft sowie Mitarbeiterinnen und Mitarbeitern der Stadtregierung - die zwar kein Stimmrecht, aber dennoch beträchtlichen Ein- 
fluss haben - zusammen. Der COP definiert zum einen die allgemeinen Kriterien für die Ressourcenallokation und diskutiert beziehunsgweise erarbeitet zum anderen - als ,main participatory institution“ (ebd.: 320) - auf Grundlage der Vorgaben aus den regionalen und thematischen BürgerInnenversammlungen einen stadtweiten Budgetentwurf und Investitionsplan und legt diese dann in weiterer Folge im Stadtrat vor. Jegliche Diskussions- und Meinungsbildungsprozesse werden der Transparenz und Zugänglichkeit wegen umfassend protokolliert (vgl. Santos 1998: o.S., Santos 2005: 318ff, Fung/Wright 2001: 14, Avritzer o J: 4f und Becker 2001a: 3f).

Die Demokratisierung der Wirtschaftspolitik mit Hilfe des Partizipativen Budgets verläuft anhand einer Reformulierung von Wirtschaftspolitik und im Besonderen von Budgets ,with a new social grammar (...), this grammar has two elements: the fair distribution of public goods and the democratic negotiation of the access to these goods among the social actors themselves" (Avritzer/Santos 2003: 18). Es geht also darum, neben den Entstehungsprozessen von Budgets auch die Inhalte der Budgets zu demokratisieren und Gerechtigkeitsüberlegungen in den Mittelpunkt zu rücken. Eine solche distributive Gerechtigkeit wird in Porto Alegre anhand eines Verteilungskriterienkatalogs gewährleistet: Nachdem die jeweiligen regionalen Versammlungen und thematischen Foren ihren spezifischen Bedarf und ihre Prioritäten definiert und hierarchisiert haben, wird die Verteilung der Einnahmen letztlich mittels einer Kombination von allgemeinen Kriterien, die vom COP - also indirekt von der Bevölkerung - definiert werden und von technischen Kriterien, die von der Regierung festgelegt werden, vorgenommen. „That is, the decisions and rules established by the participants are made compatible with the technical and legal demands of governmental action, also respecting financial limits" (ebd.). Während die technischen Kriterien der „technical or economic viability“ darstellen, die von ,the executive in accordance with federal, state or city legal norms" (Santos 2005: 317) definiert werden, kann die Bevölkerung die Verteilungskriterien gestalten, da diese „nicht durch bürokratische oder betriebswirtschaftliche Grundsätze vorgegeben sind" (Novy/Leubolt 2004: 11). Die allgemeinen Verteilungskriterien werden öffentlich diskutiert und können jedes Jahr neu festgelegt werden, beinhalten aber in der Regel jeweils die gesamte Bevölkerungszahl, die Bedürftigkeit, den Bedarf beziehungsweise die Mängel im jeweiligen Bezirk und die Investitionspräferenzen, -prioritäten und -entscheidungen im Bezirk: „The ranking of priorities balances three criteria: the previous access of the population to the public good in question, the population of the region and the population's decision" (Avritzer 2000: 5). Das Partizipative Budget ,is a process of decision making based upon general rules and criteria of distributive justice discussed and approved by regular, institutional organs of participation in which the popular classes have majority representation" (Santos 2005: 323). Diese Kombination von partizipativen Aushandlungs- und Diskussionsprozessen mit generellen und 
technischen Verteilungsregeln soll Transparenz von wirtschaftspolitischen Entscheidungen ebenso wie deren Objektivität und Nachvollziehbarkeit gewährleisten und vor allem eine „Umkehr der Investitionsprioritäten“ (Novy/Leubolt 2004: 13) forcieren.

\subsubsection{Standortbestimmung Partizipatives Budget und Demokratisierung der Wirtschaftspolitik}

Demokratisierung bedeutet - wie in Kapitel 2.4.2 herausgearbeitet - dass Möglichkeiten zur größtmöglichen Einflussnahme und Beteiligung an politischen Entscheidungen geschaffen werden und damit beziehungsweise dadurch bestehende gesellschaftliche Kräfte- und Machtverhältnisse verändert werden. Ziel ist zunächst eine Verringerung der Machtdifferentiale zwischen den Menschen und eine gleichmäßiger Verteilung der Machtgewichte unter den Menschen sowie in Folge die "Herausführung aus Unmündigkeit und Ungleichheit" (Alemann 1975: 39) um den Menschen Selbstbestimmung und Selbstverwirklichung zu ermöglichen - also eine gesamtgesellschaftliche Emanzipation. Für eine Demokratisierung von Wirtschaftspolitik ist die Einführung eines demokratischen Prozesses der Willensbildung und Entscheidungsfindung von Wirtschafts- und Finanzpolitik ebenso wie das Einfließen von Gerechtigkeitsüberlegungen in deren Inhalte relevant (vgl. Kapitel 3). Einflussnahmemöglichkeiten an politischen Entscheidungen können gewährleistet werden indem wirtschaftspolitische Entscheidungsprozesse transparent, partizipativ und ,accountable“ gestaltet werden und alle Bürgerinnen und Bürger gleichwertige Einfluss- und Mitbestimmungsmöglichkeiten haben. Machtdifferentiale können verringert werden indem wirtschaftspolitische Entscheidungen mit Gerechtigkeitsüberlegungen angereichert werden, denn aufgrund der Verteilungsfunktion von Budgets können ökonomische Bedingungen gleichmäßiger verteilt werden und so mehr Verteilungsgerechtigkeit geschaffen werden, was wiederum die Voraussetzung für gleichberechtigte und gleichwertige Mitbestimmungsmöglichkeiten aller Bürgerinnen und Bürger ebenso wie für eine gesamtgesellschaftliche Emanzipation ist. Hierauf Bezug nehmend möchte ich anhand der drei Vektoren Input (demokratische Willensbildung), Output (Gerechtigkeitsüberlegungen) und Institutionen (vgl. Kapitel 3) das Partizipative Budgets als Beitrag zu einer Demokratisierung der Wirtschaftspolitik genauer analysieren.

\subsubsection{Input: Mitbestimmung und Beteiligung}

In den ersten Jahren 1989 und 1990 war die Beteiligung der Bevölkerung am Partizipativen Budget in Porto Alegre sehr niedrig. Es bestanden vielfältige Zweifel der Bürgerinnen und Bürger ob der Kapazitäten und Funktionsweisen. Seither ist sowohl das Vertrauen in das Partizipative Budget (vgl. Leubolt 2003: 
47), als auch die Beteiligung mit wenigen Ausnahmen (in den Jahren 1994, 1996, 2000 sowie 2003) zunächst sehr stark, danach ständig stetig gestiegen (vgl. Abbildung 2). Mittlerweile nehmen 1,5\% bis knapp 2\% der Stadtbevölkerung jährlich an den BürgerInnenversammlungen und thematischen Foren teil (vgl. Avritzer 2002: o.S.), wobei Schätzungen des Bürgermeisterbüros zufolge, weitaus höhere Zahlen zustande kommen, wenn die intermediären Versammlungen sowie die regionalen und thematischen Versammlungen stärker berücksichtigt werden. Demzufolge ergaben diese Schätzungen schon im Jahr 1998, dass mindestens $8 \%$ der Stadtbevölkerung am Partizipativen Budget teilnahm (vgl. Santos 1998: o.S.).

Abbildung 2: Anzahl der Beteiligten am Partizipativen Budget in Porto Alegre 1990-2003

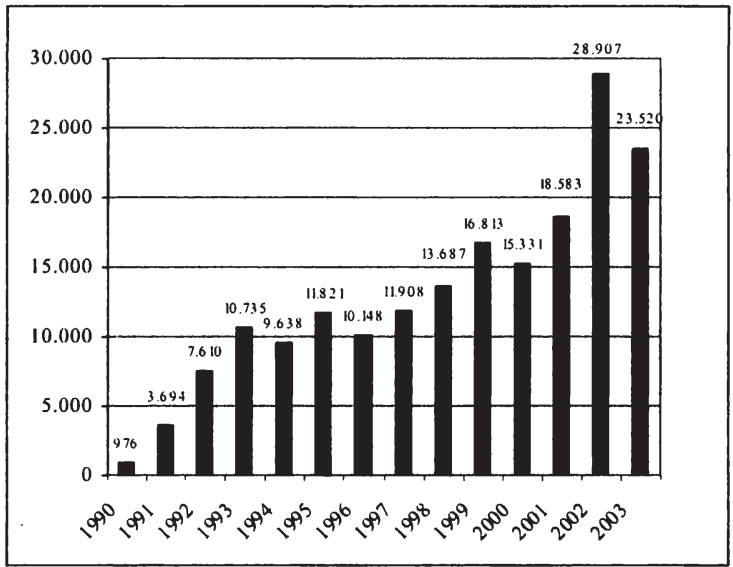

Quelle: CIDADE ${ }^{17}$, Avritzer 2000: 12f, eigene Darstellung

\subsection{Sozioökonomisches Profil der Teilnehmenden}

Erkenntnissen einer Umfrage aus dem Jahr 1995 zufolge gehört die Mehrheit der am Parizipativen Budget Teilnehmenden ,with an average age of forty-one ${ }^{18}$

17 Die Angaben zu den TeilnehmerInnenzahlen am Partizpativen Budget differieren je nach Quelle meist sehr stark, da nicht alle Bürgerinnen und Bürger, die in den jeweiligen intermediären Versammlungen in den einzelnen Nachbarschaften der jeweiligen Bezirke teilnehmen konsistent erfasst werden konnten, was die ohnehin schon schwierige Erhebungen aufgrund der unterschiedlichen TeilnehmerInnenzahlen der ersten und zweiten Runde nochmals erheblich erschwert. Ich werde im Folgenden auf die, vom nicht-staatlichen Forschungsinstitut CIDADE veröffentlichten Zahlen zurückgreifen, da deren Erhebungen seit Beginn des Partizipativen Budgets zu einem großen Teil geschlechtsspezifisch aufgeschlüsselt wurden und für meine Forschung geschlechtssensible Statistiken unerlässlich sind. 
(...) to the popular classes: $40 \%$ have a household income of one to three times the minimum wage and have elementary education. Around $60 \%$ of the participants have an income of up to five times the minimum wage. A significant number of the people surveyed have flexible jobs as regards time and schedule, for example, self-employed, retired, and at-home workers" (ebd.). Diese Umfrage ergab, entgegen allen Erwartungen, dass nicht ,middle-class and wealthy residents (...) dominate the budget assemblies" (Abers 2000: 121) vielmehr war die Mehrheit der am Partizipativen Budget Teilnehmenden ,poor and less-educated" (ebd.). Diese Ergebnisse lassen sich zum größten Teil anhand der jüngsten zur Verfügung stehenden Daten zu den Teilnehmenden am Partizipativen Budget aus dem Jahr 2002 bestätigen.

Abbildung 3: Beteiligung an den einzelnen Institutionen des Partizipativen Budget in Porto Alegre nach dem Familieneinkommen der Teilnehmenden, 2002

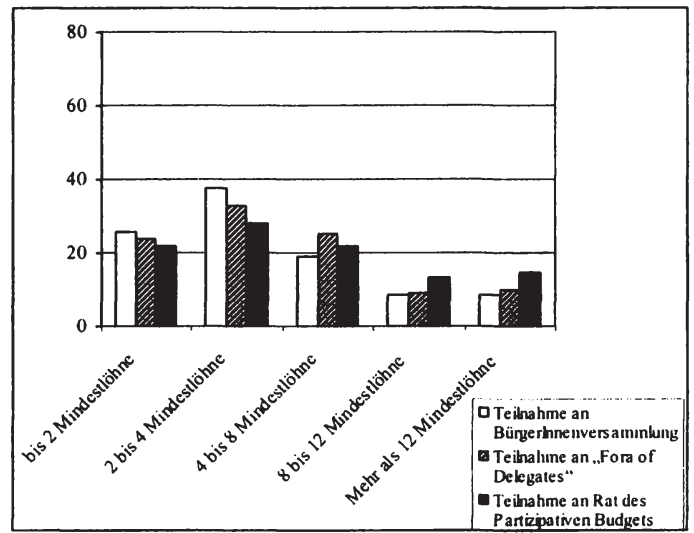

Quelle: CIDADE, eigene Darstellung

18 Die Beteiligung an den einzelnen Institutionen des Partizipativen Budget in Porto Alegre nach dem Alter der Teilnehmenden kann anhand der Daten aus dem Jahr 2002 folgendermaßen skizziert werden:

\begin{tabular}{|c|c|c|c|}
\hline & \multicolumn{3}{|l|}{ Teilnahme an } \\
\hline Alter & $\begin{array}{c}\text { BürgerInnen- } \\
\text { versammlungen }\end{array}$ & $\begin{array}{l}\text { „Fora of } \\
\text { Delegates“ }\end{array}$ & $\begin{array}{c}\text { Rat des } \\
\text { Partizipativen } \\
\text { Budgets }\end{array}$ \\
\hline $16-25$ & $8,4 \%$ & $6,5 \%$ & $3,3 \%$ \\
\hline $26-33$ & $17,6 \%$ & $12,6 \%$ & $14,8 \%$ \\
\hline $34-41$ & $21,4 \%$ & $19,5 \%$ & $24,6 \%$ \\
\hline $42-49$ & $19,8 \%$ & $24,4 \%$ & $24,6 \%$ \\
\hline$>50$ & $32,8 \%$ & $37,0 \%$ & $32,8 \%$ \\
\hline
\end{tabular}

Quelle: CIDADE, eigene Darstellung 
So zeigt Abbildung 3, dass im Speziellen an den BürgerInnenversammlungen aber auch als Delegierte vor allem die ärmste Bevölkerung stark vertreten ist: $63 \%$ aller Teilnehmenden an den BürgerInnenversammlungen kamen aus den armen Schichten, die bis zu vier Mindestlöhne verdienten. Es kann demgemäß noch immer bestätigt werden: „the household incomes of the budget participants are significantly lower than those of the population as a whole" (Abers 2000: 122).

Auch hinsichtlich der Schulbildung der Teilnehmenden stellen, wie in Abbildung 4 dargestellt, die „better-educated“ (Abers 2000: 122) bei weitem nicht die Mehrheit der Teilnehmenden. Dennoch erwies sich das Partizipative Budget auch für die Bevölkerung mit höherer Bildung - speziell mit Universitätsabschlüssen (vgl. Abers 2000: 121) - als äußerst anziehend. Hierzu ist anzumerken, dass sich die sozioökonomische Situation der Teilnehmenden an den thematischen Foren zumeist stark von der der Teilnehmenden an den regionalen BürgerInnenversammlungen unterscheidet: Die thematischen Foren setzen sich größtenteils aus Mittelklasse Bürgerinnen und Bürgern mit höherer Bildung und besseren Einkommen zusammen. Dies lässt vermuten, dass während ,middle-class people might not have been as concerned with the basic, small-scale infrastructure demand at the regional level, they were more likely to be interested in general policy issues and larger-scale infrastructure project" (Abers 2000: 122). Eine andere ,(although not mutually exclusive) explanation is that the more general, policy-based themes debated in the thematic councils required higher levels of education and time to understand, and therefore were more accessible to better-off citizens" (ebd.).

Abbildung 4: Beteiligung an den einzelnen Institutionen des Partizipativen Budget in Porto Alegre nach der Schulbildung der Teilnehmenden, 2002

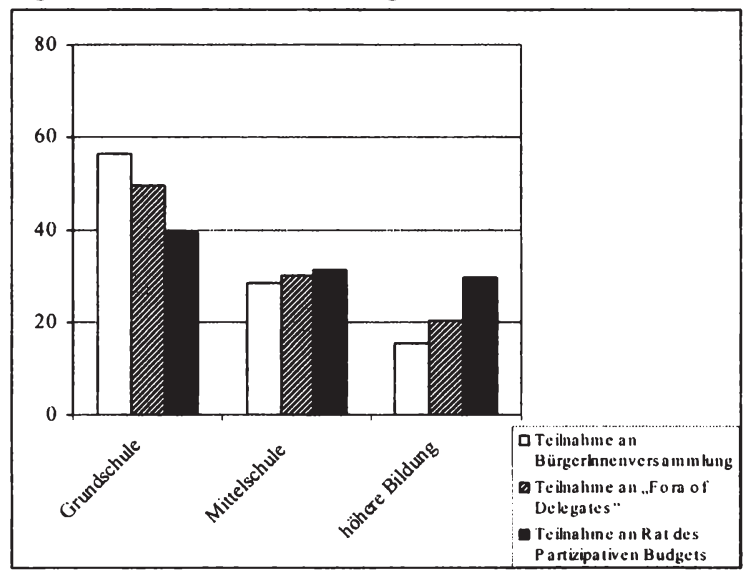

Quelle: CIDADE, eigene Darstellung 
Die Daten zur sozioökonomischen Situation der Teilnehmenden am Partizipativen Budget in Porto Alegre aus dem Jahr 1995 sowie die dargestellten aus dem Jahr 2002 widerlegen jedenfalls das modelltheoretische „Standardmodell der politischen Beteiligung" (Schmidt 2000: 267) deutlich: Laut dieses Beteiligungsmodells basiert ein hohes Niveau politischer Beteiligung auf einem hohen „socioeconomic ressource level (SERL)“ (Verba et al 1987: 63). Hierbei bezeichnen die sozioökonomischen Ressourcen, die Menschen zur Verfügung haben, ihre Bildung und ihr Einkommen: „Je höher das Qualifikationsniveau, je höher die berufliche Position und je höher das Einkommen, desto höher die Ressourcenausstattung“ (Schmidt 2000: 266). „Education, wealth, and high-status occupation - the usual components of upper status - provide the resources that individuals can convert into political activity" (Verba et al 1978: 11). Es wird davon ausgegangen, dass je besser diese Ressourcenausstattung, desto „tendenziell stärker sind die positiven Einstellungen der Bürger zur Politik und desto fester ist die Überzeugung, durch individuelle Beteiligung politisch etwas bewirken zu können" (Schmidt 2000: 266).

„Those citizen who are wealthier, better educated, or who come from more prestigious ethnic or racial or linguistic groups hold a disproportionate share of political influence. The political stratification system in turn reinforces the socioeconomic one: The economically and socially better-off dominate politics" (Verba et al 1978: 2). Daher ist angeblich bei jenen mit schwacher Ressourcenausstattung auch die „Einstellung gegenüber der Politik weniger positiv und alles in allem wird die Überzeugung, politisch wirksam zu sein, schwach und die politische Beteiligung gering sein" (Schmidt 2000: 266f). Denn die Grenzkosten der Partizipation an politischen Entscheidungen sind vor allem für arme Menschen, „who face a daily struggle to provide the bare minimum for sheer physical survival" (Abers 2000: 118) besonders hoch - sie können sich den Luxus, sich in politischen Aktivitäten zu engagieren, zumeist nicht leisten. Sidney Verba, Norman Nie und Jae-On Kim bezeichnen dies als die positive Korrelation zwischen dem SERL und politischer Partizipation: „The higher an individual's socioeconomic resource level, the higher will be the activity" (Verba et al 1978: 65f).

Diese Ausführungen werden durch die, dieser Dissertation zugrunde liegenden Daten zu den Teilnehmenden am Partizipativen Budget in Porto Alegre zum größten Teil widerlegt: „In the relationship between participation and socioeconomic grouping, there is a strong correlation although not in the direction expected by those who predict that the better-off will participate more" (Abers 2000: 124f). Die Daten bestätigen, dass Angehörige von reicheren Bevölkerungsgruppen nicht eher und mehr dazu tendierten am Partizipativen Budget teilzunehmen als Angehörige der ärmeren. Aus den Daten ist zu schließen, dass die regionalen BürgerInnenversammlungen vor allem der armen Bevölkerung ein Forum für die Formulierung ihrer Bedürfnisse gab, „better-off individuals 
either had fewer demands to make, or they made them through other forums. The implication of all this is that it was the middle class and not the poor that had minority status in the budget assemblies, particularly at the regional level, where most of the activity took place" (ebd.: 125).

\subsection{Geschlechtsspezifisches Profil der Teilnehmenden}

Da die politische Beteilung durch weitere Einflussgrößen - abgesehen von der sozioökonomischen Ressourcenausstattung (vgl. Kapitel 3.1.3.1.1) - beeinflusst wird, wurde das Standardmodell der politischen Beteiligung erweitert und umgebaut, wobei beispielsweise die Kategorie Geschlecht hinzugefügt wurde, da diese die politische Beteiligungs-(Bereitschaft) ebenfalls stark beeinflusst (vgl. Schmidt 2000: 267).

Verba et al unterstreichen, ,most studies have shown that men are more likely to be politically active than women. The disparity in activity grows greater as one moves up from mass political activities such voting, to more difficult political acts” (Verba et al 1978: 234f). „Frauen gelten [damit] als die ,schlechteren Demokratinnen' weil sie im Vergleich zu den Männern weniger Punkte auf der Partizipationsskala zu verzeichnen haben und in geringerem Maße als Männer die ihnen von der parlamentarischen Demokratie zu Verfügung gestellten Handlungsräume nutzen“" (Sauer 2001: 210).

Laut feministischer Politikwissenschaft lässt sich jedoch im letzten Jahrzehnt ein neuartiges geschlechtstypisches Partizipationsmuster erkennen: Es geht nicht alleine um den „männlichen politischen Aktivbürger" und die „unpolitische Frau“, sondern vielmehr darum dass Männer ,eher in der ,großen Demokratie' [agieren], sie besetzen Ämter in Parteien sowie in nationalen und internationalen Parlamenten und Regierungen, Frauen hingegen engagieren sich in der ,kleinen Demokratie', [vor allem] in sozialen Bewegungen" (ebd.: 212). Auch spezifisch lateinamerikanische Untersuchungen ergeben ein sehr ähnliches Bild: „Women typically take part in everyday, neighborhood-level activities, but are less likely to rake on participatory roles that require them to regularly leave the neighbourhood, to speak in public, or to make decisions that require more self-confidence and status" (Abers 2000: 127).

Sowohl die Annahmen der feministischen Politikwissenschaft als auch die Ergebnisse lateinamerikanischer Untersuchungen können mithilfe der TeilnehmerInnenzahlen am Partizipativen Budget bestätigt werden. Während also das sozioökonomische Profil der Teilnehmenden den Annahmen des Standardmodells der politischen Beteiligung widerspricht, entspricht das Geschlechterprofil eher den Argumentationen der Literatur (vgl. ebd.). 
Am Partizipativen Budget nahmen im Zeitablauf zwar grundsätzlich ungefähr gleich viele Frauen wie Männer teil, im Jahr 2000 lag der weibliche Anteil sogar deutlich über dem männlichen (vgl. Abbildung 5).

Abbildung 5: Beteiligung am Partizipativen Budget in Porto Alegre 1995, 1998 und 2000 nach Geschlecht der Teilnehmenden

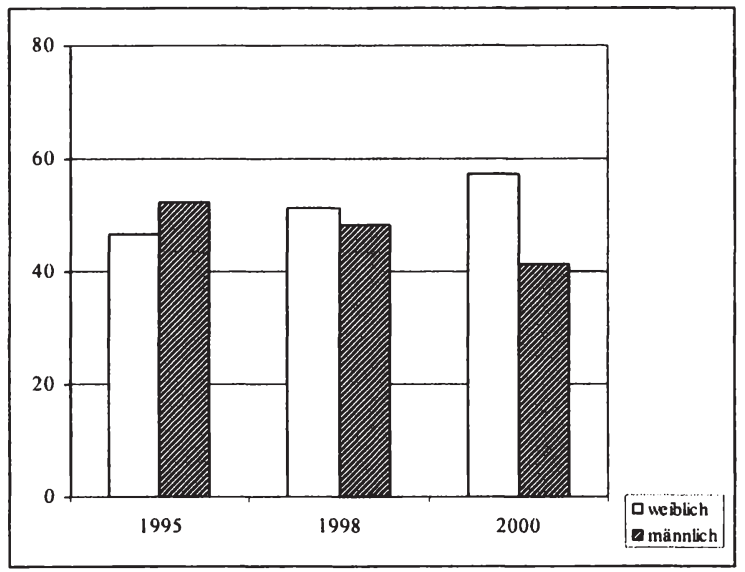

Quelle: CIDADE, eigene Darstellung

Die Rolle der Frauen im partizipativen Budgetprozess jedoch erscheint prototypisch (vgl. Abbildung 6). „The participation of women, though rather balanced at the base (...) decreases as the decision scale rises" (Santos 1998: o.S.). „Stronger differences between men's and women's participation appeared in the subset of those elected to the various year-round forums of the participatory budget" (Abers 2000: 128).

Frauen sind auf der Ebene der allgemeinen BürgerInnenversammlungen weitgehend zu gleichen Teilen wie Männer vertreten. Jedoch werden sie im Vergleich zu Männern kaum in Positionen gewählt beziehungsweise lassen sich weniger in Positionen wählen, die regelmäßige Reisen zu Versammlungen außerhalb der eigenen Nachbarschaft notwendig machen und einen entscheidungstragenden Status haben. „This was not only a result of discrimination against women by others and of women's own concerns about free time or leaving their neighbourhoods. All too often (...) women declared bashfully that they were not capable of taking on roles, such as coordinator, special representative to some assembly, or municipal council member" (Abers 2000: 128). Frauen die dennoch in höhere Funktionen und Gremien gewählt wurden, werden dort zumeist wie Sekretärinnen behandelt und sind hauptsächlich für die anfallenden administrativen Tätigkeiten verantwortlich, wie beispielsweise die Protokollierungen der Sitzungen, „and less often participated vocally in the discussions taking place“ (ebd.: 129). 
Abbildung 6: Beteiligung an den einzelnen Institutionen des Partizipativen Budget in Porto Alegre nach dem Geschlecht der Teilnehmenden, 2002

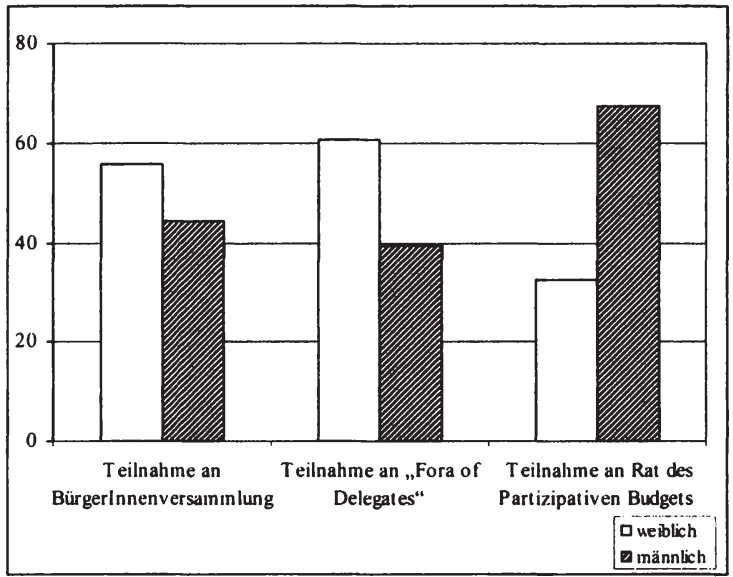

Quelle: CIDADE, eigene Darstellung

Tabelle 1 zeigt außerdem, dass sich Frauen durchschnittlich über alle Gremien des Partizipativen Budgets hinweg weniger oft zu Wort melden als Männer beziehungsweise Frauen in allen Gremien weniger oft zu Wort kommen als Männer: „The problem of self-confidence was endemic among women participation in the bugdet assemblies, especially [among] poor women" (ebd. Hervorhebung im Original).

Tabelle 1: Sprechen während der Sitzungen des partizipativen Budgets in Porto Alegre

\begin{tabular}{|l|r|r|}
\hline & Frauen & Männer \\
\hline Meistens & $6,7 \%$ & $8,8 \%$ \\
\hline Manchmal & $12,5 \%$ & $15,6 \%$ \\
\hline Selten & $13,2 \%$ & $10,6 \%$ \\
\hline Nie & $37,8 \%$ & $38,1 \%$ \\
\hline Ein Mal pro & $24,8 \%$ & $22,8 \%$ \\
\hline Keine & $5,0 \%$ & $4,1 \%$ \\
\hline
\end{tabular}

Quelle: Leubolt 2003: 53

Zusammenfassend kann festgehalten werden, dass ,the policy did not create the sort of ,participatory elite' (...) instead, it actually stimulated the emergence of broad-based citizen participation that was (...) egalitarian and widespread" (Abers 2000: 132). Leonardo Avritzer erklärt dieses hohe Niveau der Partizipa- 
tion durch die arme Bevölkerungsschichten dadurch, dass partizipative Praktiken auf der Ebene zivilgesellschaftlicher Lokalinitiativen schon vor der Einführung des Partizipativen Budgets existierten (vgl. Kapitel 3.1.1), ,thus, a previous knowledge on how to participate is already available" (Avritzer 2002: o.S.). Dementsprechend kann die hohe Beteiligung der Ärmeren und auch der Frauen vor allem auf Ebene der regionalen BürgerInnenversammlungen folgendermaßen begründet werden: Die Teilnehmenden konnten auf Erfahrungen aus einer langen Tradition von Partizipation vor allem auf Lokal- und Nachbarschaftsebene zurückgreifen, die sich vor allem in den Armenvierteln entwickelt hatten. Diese Lokalinitiativen waren das Resultat der Bestrebungen und Forderungen der armen Bevölkerung nach mehr Mitsprache und verbesserten Lebensbedingungen. Demgemäß ist es nicht verwunderlich, dass sie wussten wie sie ihre Präsenz in den Versammlungen sicherstellen konnten. Außerdem ist zu vermuten, dass sowohl die schlechter gestellte Bevölkerung sowie Frauen vor allem dort partizipieren, wo Entscheidungen zu ihren unmittelbaren Lebenssituationen und zur Verbesserung ihrer Lebensbedingungen getroffen werden (vgl. dazu Kapitel 3.1.3.3).

\subsubsection{Institutionen: Kombination direkter und repräsentativer Demo- kratieelemente}

Der Einfluss politischer Institutionen aufgrund derer eine Beteilung von Bürgerinnen und Bürgern erst ermöglicht wird, ist wesentlich. Dies anerkennen auch Verba et al und revidieren sogar ihr „Standardmodell der politischen Beteiligung“ (vgl. Kapitel 3.1.3.1), indem sie zugestehen: „Institutions can mobilize citizens to a level of activity above that which would be predicted by their socioeconomic resource level, or institutions can inhibit political activity so that it is at a level below that which one would predict on the basis of socioeconomic characteristics. Variations in the nature and intensity of institutional interference explain the variation (...) in the participation disparity between the have and have-nots" (Verba et al 1978: 80).

So argumentieren auch Andreas Novy und Bernhard Leubolt, dass für das Partizipative Budget in Porto Alegre die Institutionalisierung ein wichtiges Element war um eine Demokratisierung des Budgeterstellungsprozesses zu ermöglichen, denn durch „Institutionalisierung wird die demokratische Mitbestimmung über die Wirtschaftspolitik des Lokalstaats entscheidend ausgebaut und gestärkt. Das Besondere liegt in der Beteiligung an Entscheidungsprozessen" (Novy/Leubolt 2004: 11).

Der unmittelbare Anstoß für eine Demokratisierung des Budgetprozesses kam „from above" (Abers 2000: 195). Abers bezeichnet das Partizipative Budget daher als eine „state-sponsored participatory democracy” (ebd.: 227): „In Porto Alegre, the government helped encourage the mobilization and organization of 
participants ,from above' (...). What is important to note here is that neighbourhood mobilization was more an effect than a cause of participatory policymaking. But as it grew, it bolstered the participatory budget policy" (ebd.: 107).

Das Partizipative Budget enthält „Elemente sowohl der direkten als auch der repräsentativen Demokratie“ (Becker 2001a: 3), wobei „das Originelle des Verfahrens darin liegt, dass die Elemente der direkten und repräsentativen Demokratie mit einem organisierten Diskussions- und Meinungsbildungsprozess verbunden sind" (Becker 2001a: 4). So „werden direktdemokratische Instrumente wie Versammlungen mit der Arbeit von gewählten repräsentativ-demokratischen Gremien kombiniert" (Novy/Leubolt 2004: 11). Vorschläge werden nicht von Parteien und Großorganisationen gemacht und anschließend von Massenmedien propagiert, sondern entstehen vielmehr , in einem komplexen Diskussions- und Aushandlungsprozess" (Becker 2001a: 4). Dementsprechend können die Strukturen des Partizipativen Budgets immer wieder neu angepasst werden und haben „ein hohes Maß der Selbstverwaltung“. Teil des Prozesses des Partizipativen Budgets ist, die Geschäftsordnung jedes Jahr zu adaptieren. Auch die personellen Strukturen der Institutionen des Partizipativen Budgets, beispielsweise des COP sollen flexibel und veränderbar bleiben, weshalb nur ,eine einmalige Wiederwahl möglich ist" (ebd.).

Auch Santos beschreibt das Partizipative Budget als ,a structure and a process of community participation based (...) on a set of institutions that function as mechanisms or channels of sustained popular participation in the decision-making process of the municipal government" (Santos 1998: o.S.).

Das institutionelle Arrangement des Partizipativen Budgets ist grundsätzlich durch drei Arten von Institutionen gekennzeichnet: Die erste Art von Institutionen setzt sich aus administrativen Einheiten der Stadtregierung zusammen, deren Aufgaben das Führen der Budgetdebatten mit den Bürgerinnen und Bürgern, das Koordinieren der BürgerInnenversammlungen und der Treffen des COP und auch das Übersetzen der Forderungen der Bevölkerung in technisch und ökonomisch „viable municipal action by submitting them both to the general and the technical criteria" (ebd.) beinhalten. Die zweite Art Institutionen sind Gemeindeorganisationen, die autonom gegenüber der Stadtregierung sind und zum größten Teil aus regionalen Organisationen und vom Organisationspotential der einzelnen Regionen abhängig zusammengesetzt sind. Ihre Aufgabe ist es zwischen der BürgerInnenpartizipation und den Prioritätensetzungen für die jeweilige Region zu vermitteln. Die dritte Art der Institutionen ist vorgesehen um eine permanente Vermittlung und Interaktion zwischen den ersten beiden Arten zu gewährleisten. Sie werden als ,regularly functioning institutions of community participation" (ebd.) bezeichnet und umfassen die regionalen und thematischen BürgerInnenversammlungen, die Delegiertenforen ebenso wie den Rat des Partizipativen Budgets (vgl. ebd. und auch Kapitel 3.1.2). 
Diese Strukturen des Partizipativen Budgets sind eingebunden in eine „double institutional articulation with the institutions of representative democracy at the urban level (...) and with the representative institutions derived from participatory democracy at the community level" (Santos 2005: 232). Diese beiden Formen der Demokratie können laut Avritzer und Santos nur auf zwei mögliche Arten miteinander kombiniert werden: „coexistence“ oder ,complementarity“ (Avritzer/Santos 2003: 24). „Coexistence“ impliziert die Existenz verschiedener verfahrensrechtlicher Formen, verschiedener Formen der administrativen Organisation und Variationen der institutionellen Gestaltung auf verschiedenen Ebenen. Dies würde beispielsweise eine ausschließlich repräsentative Demokratieform auf Ebene des Nationalstaats mit möglichen Formen partizipativer Demokratie auf Gemeindeebene bedeuten. „Complementarity“ hingegen bezeichnen sie als ,a more profound articulation between representative democracy and participatory democracy” (ebd.). „Complementarity“ setzt voraus, dass partizipative Verfahren, öffentliches Monitoring der Regierung und Prozesse der öffentlichen Deliberation von Regierungen als Substitut für Teile der repräsentativdemokratischen Prozesse anerkannt werden: Dieses Konzept unterscheidet sich von dem der "Coexistence“ - am Beispiel Porto Alegres zu sehen - in der politischen Entscheidung „to expand participation at the local level through the transfer and/or devolution of decision-making prerogatives at first held by governments" (ebd.: 25). Das Ziel ist „to associate with the process of strengthening local democracy forms of cultural renovation related to a new political institutionality which reintroduces the questions of cultural plurality and the necessity of social inclusion into the democratic agenda" (ebd.: 24). Im Falle des Partizipativen Budgets in Porto Alegre ermöglichten die partizipativen Arrangements ein Aneinanderfügen von Diskussions- beziehungsweise Aushandlungsprozessen, distributive Gerechtigkeit und Transfers von Vorrechten von der nationalstaatlichen auf die lokale Ebene sowie von RepräsentantInnen zu den partizipativen Arrangements. „Representative democracy is summoned to integrate proposals of cultural recognition and social inclusion into the political-electoral debate" (ebd.: 25).

Seit Beginn des ersten Partizipativen Budgets in Porto Alegre gab es Bestrebungen „to achieve a fine-tuning between participation and representation, that is, to improve the mechanisms of representation needed for participatory democracy to function adequately" (Santos 1998: o.S.). Denn auch in einer solch kraftvoll partizipativen Umwelt besteht keine Garantie dafür, dass die Repräsentation auch tatsächlich funktioniert, auch hier könnten die Prinzipien der Mandate nicht respektiert, die Prioritätensetzungen der BürgerInnenversammlungen manipuliert oder auch die Repräsentation an sich professionalisiert werden, wenn Delegierte ihre Posten zu lang innehaben. „In order to neutralize the possibility of such deviations, the term of the PB councillors may be revoked at any time by the assemblies that elected them, and no candidate can be elected more 
than twice to a given position" (ebd.). Die Mitglieder des Stadtrates, der Stadtverwaltung ebenso wie diejenigen, die andere öffentliche Positionen innehaben dürfen überhaupt nicht in den COP gewählt werden.

Außerdem wurde im Zuge der zunehmenden Partizipation der Bürgerinnen und Bürger und der Notwendigkeit die Positionen von Minoritäten zu sichern ein Schlüssel für die Wahl der Delegierten erarbeitetet um eine proportionale Repräsentation der Bevölkerung zu ermöglichen. Die Beziehung der Partizipation der Bevölkerung und der Repräsentation der Bevölkerung durch die Bevölkerung ist jedoch nicht so reibungslos, wie sie möglicherweise erscheint: „The problems center on the following two questions: the ratio of represented/representatives and the quality of representation (autonomy, accountability, and retorno or transparency)" (ebd.).

Seit Beginn des Partizipativen Budgets gab es Spannungen zwischen der Exekutive und den Lokalinitiativen wegen der Kriterien, die verwendet wurden, um die Relation zwischen der Zahl der Teilnehmenden an Versammlungen und der Zahl der dort gewählten Delegierten zu bestimmen. Vor allem als die Zahl der Teilnehmenden stieg, stieg auch die Zahl der zu repräsentierenden Personen pro einer/einem Delegierten äußerst stark an. Viele der Lokalinitiativen andererseits bestehen seit jeher darauf, dass die Zahl der Delegierten so groß wie möglich sein soll, denn sie verstehen das Partizipative Budget als einen ständigen Lernprozess, indem die meisten Informationen jedoch nur innerhalb der Institutionen - dem COP und den Delegiertenforen - zirkulieren. Da so viele Menschen wie möglich Zugang zu diesem Lernprozess sowie den Informationen haben sollten, argumentieren sie für eine größtmögliche Zahl an Delegierten. Die Exekutive reagiert hierauf mit der Notwendigkeit "to make compatible direct democracy and representative democracy" (ebd.) und dem Argument der deliberativen Effizienz.

Dennoch konnten die Regierung und die Verwaltung Porto Alegres eine Balance schaffen zwischen ,on the one hand, building the basic capacity to govern competently and to survive in office, and on the other hand, promoting policies that radically challenged political traditions in the city" (Abers 2000: 109). Hierbei ist zu betonen, dass die Einführung des Partizipativen Budgets einerseits Transparenz in Regierungsentscheidungen brachte und andererseits signifikante umverteilende Wirkungen hatte, was sowohl von Seiten der Exekutive als auch der Bevölkerung beziehungsweise der Lokalinitiativen intendiert worden war und demgemäß auch von beiden Seiten honoriert wird.

\subsubsection{Output: Verteilungsgerechtigkeit}

Das Partizipative Budget konnte also mehr erreichen, als nur die politische Macht auf die Bevölkerung und damit auch auf die ärmere Bevölkerung auszu- 
dehnen: „Popular actors are invited into the budget process, and their participation has a direct impact on the allocation of resources (...) PB allows new actors into government decision-making, and forces old actors to respond to demands that are more representative than a few powerful lobbies and important electoral constituencies" (Schneider/Goldfrank 2002: 14). So wurde das Partizipative Budget vor allem als Form distributiver Gerechtigkeit bei der Allokation von öffentlichen Ressourcen im Zuge eines partizipativen Prozesses bekannt (vgl. Santos 1998: o.S.): Das Partizipative Budget unterstreicht ,the need for democracy to be articulated with a new social grammar. In the case of participatory budgeting, this grammar has two elements: the fair distribution of public goods and the democratic negotiation of the access to these goods among the social actors themselves" (Avritzer/Santos 2003: 18). Es geht also darum, nicht nur die Entstehungsprozesse des Budgets, sondern auch die Inhalte des Budgets zu demokratisieren und Gerechtigkeitsüberlegungen in den Mittelpunkt zu rücken (vgl. hierzu Kapitel 3.1.2).

Ein Hauptargument der Partizipationsforschung ist, dass eine politische und ökonomische Gleichheit Grundvoraussetzung für eine Partizipation weiter Bevölkerungsschichten ist (vgl. hierzu exemplarisch Fraser 2001, Patemann 2004 und Phillips 1995). In Porto Alegre jedoch, „more-equal conditions were reached through the process of participation itself rather than prior to that participation" (Abers 2000: 132). Denn es ist auch ,possible for a participatory policy to simulate the mobilization of those who are not previously organized when the costs and benefits of participation are shifted in favor of the poor, the disadvantaged, and the unorganized" (ebd.: 157).

Die Regeln des Partizipativen Budgets ,specify that those who need more receive more" (Schugurensky 2004: 7). Es ist also nicht verwunderlich, dass ,the vast majority of investments has gone to poorer areas of the city and has affected poorer citizens” (Baiocchi 1999: 13). „By reversing the priorities that traditionally determined resource distribution by the municipal government, PB brought striking material results" (Santos 2005: 324) und konnte so seine umverteilende Wirkung umfassend bestätigen:

In der Jahren 1996 bis 1998 wurden im Zuge des Partizipativen Budgets beispielsweise mehr als ,260 million US dollars on projects selected by participants" (Wampler 2000: 26) ausgegeben. The vast majority of these resources went to under-serviced and poorer districts" (ebd.): Die armen Regionen Porto Alegres erhielten pro Kopf einen höheren Betrag an öffentlichen Ausgaben als die reichen Regionen (vgl. Leubolt 2003: 51), die meisten staatlichen Investitionen gingen an kleinere, jedoch zahlreichere Projekte als zuvor im traditionellen Budgetprozess - „weg von (medienwirksameren) Großprojekten hin zu kleinen, an die lokale Struktur angepassten Projekten“ (Novy/Leubolt 2004: 13). Auf Basis des Verteilungsschlüssels des COP (vgl. hierzu Kapitel 3.1.2), „der die 
zentrale Verteilung der lokalstaatlichen Ressourcen unter den Regionen demokratisch festlegt" und ,von zentraler Bedeutung für das Herausbilden einer distributiven Gerechtigkeit" ist (Leubolt 2003: 50), flossen die meisten öffentlichen Ausgaben in ,small infrastructure projects in the poor neighborhoods of the city, which had been historically neglected by government" (Abers 2000: 109). Denn es gilt beispielsweise bei einem Mangel an Infrastruktur, je größer der Mangel und die Notwendigkeit, „the higher the grade it is assigned in the overall ranking. Because of this equity principle, the PB played a key role in improving the living conditions of many people, especially in poor neighborhoods (...) In a modest way, the PB makes a connection between political democracy and economic democracy" (Schugurensky 2004: 7).

Es konnten so ganze Regionen der Stadt stark verändert und die Versorgung der Stadt mit grundlegender Infrastruktur deutlich verbessert werden: Während zwischen 1983 und 1987 jährlich durchschnittlich 5.296 Meter Kanalsystem gebaut wurden, waren es 1988 schon 8.091 Meter und zwischen 1989 und 1992 ein jährlicher Durchschnitt von 21.674 Metern. In den Jahren 1993 bis 1996 erreichte dieser Durchschnitt sogar 61.334 Meter pro Jahr. (vgl. Avritzer 2000: 19). Dementsprechend stieg zwischen 1989 und 1996 der Anteil der Bevölkerung mit Anschluss an das Kanalsytem von 46\% auf 95\% (vgl. Abers 2000: 109).

Ebenso konnte der Zugang zu Fließwasser von $80 \%$ auf $98 \%$ der Bevölkerung ausgedehnt werden (vgl. Osmani 2002: 236 und Novy/Leubolt 2004: 13). „Between 1989 and 1998 around 96.000 connections were added to the water network, and around 130.000 to the sewage network" (Miños 2002: 13). Dieser verbesserte Zugang zu Fließwasser und Kanal ,immediately improved health conditions and eliminated dangerous and stinking open sewers from yards and passageways" (Abers 2000: 148). Wodurch die Gesundheitsindikatoren der Stadt deutlich verbessert werden konnten und Porto Alegre zum Beispiel im Jahre 1999 die niedrigste Kindersterblichkeitsrate Brasiliens verzeichnen konnte (vgl. Miños 2002: 14).

Des Weiteren wurden von 1989 bis 1996 pro Jahr ca. 30 Kilometer Straßen asphaltiert (vgl. Santos 2005: 324): „Paving a street (...) also did more than just "get people out of the mud"" (Abers 2000: 148). Denn im Zuge von Asphaltierung der Straßen wurde der Zugang öffentlicher Transportmittel, Müllabfuhr, Polizeiautos sowie Rettungsfahrzeuge gewährleistet. Der Weg der Kinder zur Schule ebenso wie der Erwachsenen zur Arbeit wurde deutlich vereinfacht. „The effect in many cases was to transform dangerous, dark, and difficult-to-reach areas into integrated parts of the city" (ebd.).

"Auch im Bildungswesen konnten beachtliche Fortschritte verzeichnet werden" (Novy/Leubolt 2004: 13): Zwischen 1989 und 1996 wurde die Zahl der Kinder in öffentlichen Pflichtschulen verdoppelt (vgl. Santos 1998: o.S.), während zwi- 
schen 1989 und 1998 die Zahl der „functioning public municipal schools” von 29 auf 86 erhöht werden konnte (Baiocchi 1999: 13). „The number of students enrolled in the elementary and mid-level public schools has steadily risen since 1989 and in 2004 a full 37.5 percent of the funds distributed through PB was allocated to education" (Santos 2005: 325). Dementsprechend verzeichnete die Stadt im Jahr 1999 auch „the lowest index of school desertion among all the Brazilian state capitals" (Miños 2002: 14).

Es ist festzuhalten, dass diejenigen Menschen, die in den ärmsten und armen Regionen Porto Alegres leben, zwar im Vergleich noch immer ärmer sind, ihre Nachbarschaften und Regionen jedoch in den formellen Teil der Stadt eingegliedert wurden. Abers spricht daher von einer „Expansion of social rights and social and political inclusion" und davon, dass die arme Bevölkerung Porto Alegres ,the right to the city" (Abers 2000: 110) erhalten hat. Wodurch jedenfalls das ,engagement of the poor in terms of citizenship and access to basic rights” (Miños 2002: 13) erhöht wurde.

„In this sense, citizenship has become more substantial and inclusionary (...) Redistribution of certain public goods and services enhanced social citizenship rights, which in turn supported associational life" (Koonings 2004: 95). Ein wichtiger Faktor zur Erklärung der Mobilisierung ,around the budget policy was that it involved a type of benefit that was particularly important for poor people: the resolution of basic, immediate, and localized needs" (Abers 2000: 147). Das Abzielen auf die grundsätzlichen Bedürfnisse war ein ,excellent way to attract the poor to public forums" (ebd.: 148). Partizipation bringt - laut Abers - nicht automatisch eine Umverteilung mit sich, ,if the poor are not mobilized“ (Abers 1998: 6).

Eine solche „von der unmittelbaren Lebenswelt der Bevölkerung ausgehende "Entwicklung von unten «" (Novy/Leubolt 2004: 13) führte zu einer Ermächtigung der Teilnehmenden, ebenso wie zu einer Veränderung der Investitionsprioritäten. Avritzer unterstreicht: „The relevance of the PB as participatory policy seems to be its capacity of becoming an instrument for the participation of the lower income population and for the transfer of material public resources to this population group" (Avritzer 2000: 20). Santos bezeichnet das Partizipative Budget gar als „embryo of a redistributive democracy (...) because of its major concern with the democratic nature of the distribution" (Santos 2005: 324).

Es kann also zusammengefasst werden, dass das Partizipative Budget im $\mathrm{Zu}$ sammenhang mit Gerechtigkeits- und Umverteilungsaspekten eine äußerst erfolgreiche Budgetinitiative zur Demokratisierung der Wirtschaftspolitik darstellt, dessen Erfolg nicht nur in Porto Alegre oder Brasilien, sondern mittlerweile international anerkannt ist. Mit Hilfe des Partizipativen Budgets konnten die öffentlichen Investitions- und Ausgabenprioritäten, die von der Stadtregierung über Jahrzehnte vorgegeben wurden, verändert werden. Die emanzipato- 
rische Idee, soziale Gerechtigkeit durch neue - partizipative - Formen von demokratischen Institutionen zu erreichen, konnte durch eine Mobilisierung der ärmsten Bevölkerungsschichten forciert werden. Da diese einen Gutteil der Entscheidungen über die Verteilung der öffentlichen Ressourcen in den Foren treffen können, können sie eine Verbesserung ihrer eigenen unmittelbaren Lebenswelt erwirken und so Schritte in Richtung mehr politischer und ökonomischer Gleichheit setzen und ihre StaatsbürgerInnenrechte stärken.

\subsection{Gender Budgeting und eine Demokratisierung der Finanz- und Wirtschaftspolitik}

Auch innerhalb von Gender Budget-Initiativen besteht ein breiter Konsens über ein damit verbundenes Anliegen, Budgets und deren Erstellungsprozess partizipativer und transparenter zu gestalten (vgl. auch Kapitel 2.1): „Gender responsive budgeting needs to be organised in ways that democratise the ways in which budgets are made and implemented, and give more voice to women's concerns" (Elson 2002a: 16). Dies kann als Teil eines größeren Anliegens, nämlich der Demokratisierung von Wirtschaftspolitik, verstanden werden. Gender Budget-Initiativen sind also - ebenso wie das Partizipative Budget - grundsätzlich im Kontext eines umfassenderen Demokratisierungsanspruchs zu verorten (vgl. Cagatay et al 2000: 2).

Gender Budget-Initiativen umfassen zunächst eine geschlechtsspezifische Analyse der Dimensionen öffentlicher Einnahmen und Ausgaben, es gibt hierfür jedoch ,no single way of doing (...) and a number of analytical tools can be used. The implementation of the initiative can take several forms, depending on its political location, the extent of coverage and the stage of the budget cycle at which it is undertaken. Similarly, the findings and results can be presented in different ways, depending on the objective they are meant to achieve" (Elson 2002a: 16, vgl. Kapitel 2.1).

Es gilt jedenfalls, unter Berücksichtigung der unterschiedlichen Ausgangspositionen in Gesellschaft und Wirtschaft, die speziellen Auswirkungen der Finanzpolitik, ,auf Frauen und Männer in den Mittelpunkt des Interesses zu stellen, um einer umfassenden Gleichstellungspolitik (...) gerecht zu werden" (BEIGEWUM 2002: 12f) sowie die geschlechtsspezifischen Dimensionen öffentlicher Finanzen und deren Folgen für bestehende Geschlechterarrangements sichtbar zu machen und „letztlich gleichstellungsorientiert zu restrukturieren“ (Michalitsch 2006: 13).

Der Schwerpunkt liegt hierbei auf einer Veränderung der Prioritätensetzung hinsichtlich der strukturellen Zusammensetzung öffentlicher Einnahmen und Ausgaben. Gender Budgeting strebt nach einer Durchbrechung der impliziten Annahme, dass öffentliche Haushalte alle Bürgerinnen und Bürger in gleicher Art 
und Weise betreffen und daher die Bedürfnisse oder den Bedarf einer Durchschnittsperson befriedigen (vgl. Schratzenstaller et al 2006: 2).

Zunehmend wird Gender Budgeting auch als ein Instrument anerkannt um den Unterschied zwischen „expressed commitments by governments and the decision-making processes involved in how governments raise and spend money" (Bakker 2004: 12) zu analysieren. Denn Gender Budgeting kann als ,a mechanism for establishing whether a government's gender equality commitments translate into budgetary commitments" (Sharp/Broomhill 2002: 26) oder als ,an approach which can be used to highlight the gap between policy statements and the resources committed to their implementation, ensuring that public money is spent in more gender equitable ways" (Bellamy 2002: 4) verstanden werden: Viele Regierungen äußern zwar ihre Verantwortung für mehr Geschlechtergerechtigkeit. Zwischen diesen politischen Statements und der Art und Weise wie die Regierungen dann Geld aufbringen und ausgeben, gibt es jedoch zumeist einen großen Unterschied wobei ohne passenden finanziellen Unterbau eine Realisierung von Gleichstellungsprogrammen äußerst fraglich ist. „Most governments have also expressed commitments to greater transparency and accountability, but there is often a gap between participation and consultation in the formulation of new policies and legislation and in the allocation of resources" (Elson 2002a: 15). Gender Budgets können dazu beitragen diese Kluft zu schließen, außerdem können sie helfen, die Realisierung von Gleichstellungszielen sicherzustellen und ,they can help promote greater accountability for public resources to the people of a country, especially to women, who are generally more marginalized than men in decision-making about public money" (Elson 2002a: 15).

Hierbei geht es jedoch nicht darum, dass die gleichen Summen an Geld für Frauen und für Männer ausgegeben werden, sondern darum die Ausgaben anhand der Bedürfnisse von Frauen und Männern zu bemessen und darum, dass Regierungen ihre Geschlechtergleichstellungspolitiken an die notwendigen finanziellen Mittel für deren Implementierung koppeln (vgl. Bellamy 2002: 4, Elson 2004: 2).

Für eine Gender Budget-Initiative sind also folgende Eckpunkte charakteristisch (vgl. BEIGEWUM 2002: 18f): Die Grundlage bildet eine möglichst umfassende Analyse des Budgets mit Blick auf die Wechselwirkungen zwischen Politikbereichen, daher sollte eine partielle Analyse eines kleinen Bereichs noch nicht als Gender Budgeting bezeichnet werden. Zentraler Bestandteil des Gender Budgeting ist, dass die Analyse zu Veränderungen der Politiken hin zu mehr Geschlechtergerechtigkeit führen muss. Die Ergebnisse einer Budgetanalyse zeigen hierbei tiefer liegende Ungleichheiten bei der Verteilung und dem Zugang zu Ressourcen auf. Diese müssen schrittweise aufgedeckt werden. Die Regierung soll zudem regelmäßig Rechenschaft über die Veränderungen hin zu mehr Geschlechtergerechtigkeit ablegen, da die Nachvollziehbarkeit von politischen Ver- 
änderungen im Zusammenhang mit demokratischer Verantwortlichkeit von großer Bedeutung ist. Zur Bewertung dieser Fortschritte braucht es quantitative und qualitative Indikatoren. Auch NGOs sollten in den Gender Budgeting-Prozess einbezogen werden, da der Budgetprozess geöffnet werden soll und die Budgetgestaltung transparenter und partizipativer gestaltet werden muss.

Gender Budget-Initiativen machen sich dementsprechend folgende Veränderungen zum Ziel: Zunächst geht es in einer geschlechtsspezifischen Analyse darum die Prioritäten von Budget und Wirtschaftspolitik sichtbar zu machen. Im Zuge dessen soll der Prozess der Budgeterstellung transparent und partizipativ gestaltet werden. Dies benötigt eine Sensibilisierung für die geschlechtlichen Auswirkungen von budget- und wirtschaftspolitischen Maßnahmen in der Regierung, in der Verwaltung als auch in der Öffentlichkeit. Ziel ist ein verbesserter Einsatz öffentlicher Ressourcen hinsichtlich mehr Geschlechtergerechtigkeit. Eine weitere Veränderung ist die Forderung ,weg von der Expertokratie hin zu mehr Demokratie im Budgetprozess - Einflussnahme auf die Prioritäten der Budget- und Wirtschaftspolitik" (BEIGEWUM 2002: 20).

Ausgehend von einer geschlechtsspezifischen Budgetanalyse beinhaltet Gender Budgeting also zusammenfassend eine Fülle von Aspekten, die sich gegenseitig bedingen und ergänzen (vgl. Klatzer 2003: 37f):

- Geschlechtsspezifische Analyse der Wirkungen von Budgets unter Berücksichtigung ungleicher Ausgangspositionen und unterschiedlicher $\mathrm{Be}$ dürfnisse von Frauen und Männern

- Sichtbarmachen von geschlechtsspezifischen Machtverhältnissen, Interessen und Geschlechterhierarchien

- Transformation männlich geprägter wirtschaftspolitischer Institutionen und Prozesse, Einstellungen, Werte und Verhalten

- Thematisierung der Rolle des Staates und im Besondern der Budget- und Wirtschaftspolitik hinsichtlich einer Veränderung der bestehenden ungleichen Geschlechterverhältnisse

- Veränderung der Politiken hin zu mehr Geschlechtergerechtigkeit, Chancengleichheit und Gleichstellung

- Verpflichtung der Regierung zur Rechenschaftslegung

- Aktivierung von Frauen und Frauengruppen zur Teilhabe und Eröffnung neuer zivilgesellschaftlicher Handlungsfelder im Politikprozess

- Veränderung des Budgetprozesses im Hinblick auf einen transparenten und partizipativen Prozess der Budgeterstellung

Die Transparenz des Budgetprozesses und die „Partizipation an diesem stellen ebenso wie die Offenlegung gender-spezifischer Implikationen von öffentlichen 
Finanzen (...) und diesen zugrunde liegenden Macht- und Interessenskonstellationen zentrale Ziele von Gender Budgeting dar" (Michalitsch 2003: 229).

Gender Budget-Initiativen wollen demgemäß letztlich die demokratischen Einflussmöglichkeiten auf Budgets erweitern und einen verbesserten Einsatz öffentlicher Ressourcen hinsichtlich mehr Geschlechtergerechtigkeit forcieren (vgl. Michalitsch 2003: 230). Dafür müssen Gender Budgets so organisiert sein, dass Entscheidungen über die Verwendung und Erstellung öffentlicher Budgets demokratisiert ,und die Belange von Frauen in größerem Maße artikuliert“ (Elson 2002b: 10) und gehört werden. Denn um Finanzpolitik so umzugestalten, dass sie Geschlechtergerechtigkeit und Empowerment ${ }^{19}$ von Frauen forcieren kann, braucht es ein demokratisches finanzpolitisches System, indem der Budgetprozess transparent, accountable und partizipativ ist und alle Bürgerinnen und Bürger dieselbe Möglichkeit der Beteiligung an finanzpolitischen Entscheidungsprozessen bekommen. Dementsprechend müssen auch alle vormals ausgeschlossenen und marginalisierten Akteurinnen und Akteure in den Budgetprozess eingebunden werden.

\subsubsection{Hintergrund und Entstehungszusammenhang des Gender Budgetings}

Die weltweit erste Gender Budget-Initiative startete 1984 die australische Regierung: „The pioneers in taking action were the ,femocrats' in the government of Australia in the mid 1980s" (Elson 2004: 4). Nachdem seit den 1970er Jahren immer mehr Feministinnen Jobs in der Verwaltung, vor allem in den ,women's policy units" angenommen hatten, bildete sich eine "feminist presence within the state itself" (Sharp/Broomhill 2002: 29). Diese so genannten "women's advisers", „senior feminist policy bureaucrat(s)" (Sawer 2002: 45) aller drei Ebenen - Bund, Staaten und Territories - trafen sich zu regelmäßigen Diskussionen, die Idee eines Women's Budget kam bei einem solchen Treffen auf und wurde dort von Anne Summers, der damaligen Chefin des Office of the Status of Women aufgegriffen und weiterentwickelt. Auf Betreiben der Gender-Beauf-

19 Empowerment bezeichnet einen „emanzipatorischer Ansatz, der von Frauen aus Entwicklungsländern entwickelt wurde. Mit ihm soll ein sozialer Prozess zur „Ermächtigung“ von Frauen initiiert werden, um ihr Leben, ihr Umfeld und die Gesellschaft nach ihren Zielen und Vorstellungen zu gestalten“ (Bergmann et al 2004: 76). Auch die Europäische Kommission versteht Empowerment als die „Ermächtigung zu eigenverantwortlichem Handeln und definiert den Term ähnlich als „Prozess, in dessen Verlauf sich eine Person Zugang Möglichkeiten verschafft und sich Fähigkeiten aneignet, die sie in den Stand versetzen, ihr eigenes Leben und der Gemeinschaft, in der sie lebt, in wirtschaftlicher, sozialer und politischer Hinsicht aktiv mitzugestalten" (Europäische Kommission 1998: 14). Gender Budgeting zielt darauf $a b$, zu einem persönlichen, rechtlichen, politischen, kulturellen, sozialen und ökonomischen Empowerment von Frauen beizutragen (vgl. hierzu auch Kapitel 5.3.2). 
tragten (vgl. Michalitsch 2003: 232) wurde das erste women's budget programm auf Bundesebene als Pilotprojekt ,in parliament on budget night in 1984" (Sharp/Broomhill 2002: 26) beschlossen und in der Hälfte der australischen Ministerien eingeführt. 1987 wurde es in women's budget statement umbenannt und mit einem ,more formal status“ (Sawer 2002: 46) versehen.

Auch in den sechs australischen Teilstaaten und den zwei Territories wurden ähnliche Programme eingeführt: in South Australia, Western Australia und New South Wales im Jahr 1985, ein Jahr später in Victoria, 1989 im Australian Capital Territory, 1991 in Queensland, 1992 in Tasmania und im Jahr 1993 auch im Northern Territory (vgl. Sharp/Broomhill 2002: 27).

Das bundesstaatliche women's budget statement erreichte zu dem Zeitpunkt, als alle Ministerien dazu verpflichtet waren, eine Länge von bis zu 300 Seiten (vgl. Sawer 2002: 46) und ,attempted to examine the whole budget, tax as well as expenditure, for its likely implications for women in Australia, documenting how women were expected to benefit" (Elson 2004: 4). Es umfasste ein Gender-Audit des Regierungsbudgets hinsichtlich seiner Auswirkungen auf Frauen im Vergleich zu Männern und war als Teil des Gesamtbudgets konzipiert. Sämtliche Ministerien hatten „entsprechende Budget-Prüfungen durchzuführen und Rechenschaft über all ihrer Programme und Politiken abzulegen" (Michalitsch 2003: 233). Die Initiative zielte zunächst darauf ab „mehr über die Auswirkungen des Budgets und der Regierungsentscheidungen auf Frauen" (BEIGEWUM 2002: 44) zu erfahren, Absicht war, ,to obtain information about what is being done for women, to raise the profile of women's programs in bids for funding, but also to build into each department a clear awareness that everything they do, every dollar they spend, has an impact on women - and that impact is very often different for women than for men" (South Australia 1987: 11, zit. in Sharp/Broomhill 2002: 30). Diane Elson identifiziert drei Hauptziele des australlischen women's budget: „to raise awareness within government of the gender impact of the budget and the polices funded; to make governments accountable for their commitments to gender equality; to bring about changes to budgets and the policies they fund to improve the socio-economic status of women" (Elson 2004: 4).

Die australische Regierung unternahm die erste und auch die am längsten laufende Gender Budget-Initiative (vgl. Sharp/Broomhill 2002: 26), die neue konservative Regierung jedoch ,downgraded its commitment to the United Nations Convention for the Elimination of Discrimination Against Women" (Sharp/ Broomhill 2002: 42) im Jahr 1996 und beendete die Initiative. Im Wahlkampf 2001 verpflichtete sich zwar die Australische Labor Party im Falle eines Wahlsieges zur Wiedereinführung des women's budget statements auf Bundesebene, konnte die Wahlen aber nicht gewinnen (vgl. Sawer 2002: 63, Elson 2004: 4). 
Zusammenfassend ist festzustellen, dass die erste Gender Budget-Initiative - die „government-led initiative carried out in Australia between 1984 and 1996" (Cagatay et al 2000: 41) - eine ,bureaucratic rather than a community-based strategy" (Sawer 2002: 50) war: „The Australian women's budget programme was a 'world first' in terms of asking bureaucrats to disaggregate the impact of their mainstream programmes rather than simply highlighting programmes for women. It had considerable influence at the international level" (Sawer 2002: 60). Australien hat damit international eine Vorreiterinnenrolle übernommen, wobei sich nach wie vor zahlreiche Gender Budget-Initiativen am australischen Vorbild orientieren und dessen konzeptuellen Rahmen übernehmen (vgl. BEIGEWUM 2002: 44, Michalitsch 2003: 233). So hat die australische Initiative beispielsweise die südafrikanische - zwar zivilgesellschaftlich, aber mit dem Parlament verlinkte - Initiative direkt durch den Australien-Besuch einer südafrikanischen Delegation von Gender-SpezialistInnen und MenschenrechtskommisärInnen im Jahr 1995 beeinflusst. Ebenso direkt orientierte sich auch die philippinische Initiative und das erste Pilotprojekt des Commonwealth Sekretariats am australischen Beispiel (vgl. Sharp/Broomhill 2002: 27f).

Während in Australien die Budgets ,women's budgets“ oder auch „women's budget statements" benannt wurden, wurde der Name Gender Budgets von den nachfolgenden Initiativen verstärkt verwendet: „The first approach focuses on women as a disadvantaged or oppressed group, while the latter starts with the viewpoint that women are in many ways disadvantaged, but uses gender as a more explicit relational category of analysis, where gender refers to social relations between women and men" (Cagatay et al 2000: 37). Diese Veränderung der Terminologie reflektiert einerseits ,a move to emphasize gender as a category of analysis. It also represents a pragmatic response to overcome any tendencies to misrepresent "women's budgets" as separate budgets for women" (Sharp/Broomhill 2002: 25).

Mittlerweile haben sich in vielen Staaten Gender Bugdet-Initiativen etabliert, „es existieren zahlreiche Initiativen in unterschiedlichsten Ländern, die entsprechende Arbeiten durchführen“ (BEIGEWUM 2002: 43). So gibt es beispielsweise „Ansätze zu Gender Budgeting in Uganda, Tansania, Namibia, Mocambique, Botswana und Zimbabwe; darüber hinaus finden sich auf den Philippinen, in Peru, Chile und etlichen Staaten Ozeaniens Gender-Budget-Initiativen" (Michalitsch 2005: 15, Fußnote 9). An der Verbreitung wie auch der (Weiter-) Entwicklung von Gender Budgeting waren unter anderem internationale Organisationen wie das Commonwealth Secretariat und der United Nations Development Fund for Women (UNIFEM) federführend beteiligt: „Sie setzten bisher eine Vielzahl von Aktivitäten, veranstalteten Konferenzen, förderten Forschung sowie deren Publikation und unterstützten nationale und regionale Gender-Budget-Initiativen beratend und finanziell“" (Michalitsch 2003: 231). 
International gewann die Idee der Gender Budgets jedoch vor allem durch die Empfehlung der Beijing Platform for Action der 4. Weltfrauenkonferenz in Peking im Jahr 1995 an Bedeutung (vgl. Sharp 2003: 6, Elson 2004: 2): Paragraph 345 fordert ,the integration of a gender perspective in budgetary decisions on polices and programmes, as well as adequate financing of specific programmes for securing equality between women and men"20. Hiermit wurde die Notwendigkeit der Integration der Geschlechterperspektive in Haushaltsentscheidungen und somit die Notwendigkeit von Gender Budgets festgehalten.

In weiterer Folge engagierten sich auch andere internationale Organisationen wie das United Nations Development Programme (UNDP), die Weltbank, der Internationale Währungsfonds (IWF), die Organisation for Economic Cooperation and Development (OECD) und auch die Asian Development Bank, ebenso wie in Europa der Europarat ${ }^{21}$, das Europäisches Parlament und die Europäische

20 Dokument unter http://www.un.org/womenwatch/daw/beijing/platform/plat2.htm abrufbar.

21 Im Jahr 2005 formulierte der Europarat sogar folgende Definition von Gender Budgeting, die sowohl vom Europäischen Parlament, als auch vom Beratenden Ausschuss der Europäischen Kommission übernommen wurde: „Gender budgeting is an application of gender mainstreaming in the budgetary process. It means a gender-based assessment of budgets, incorporating a gender perspective at all levels of the budgetary process and restructuring revenues and expenditures in order to promote gender equality" (CoE 2005: 10). Gender Budgeting wird also vom Europarat als die Anwendung von Gender Mainstreaming im Budgetprozess verstanden und ,meint folglich die Integration geschlechtsspezifischer Perspektiven in den gesamten Budgetprozess" (Michalitsch 2003: 229). Gender Mainstreaming bezeichnet laut Europarat ,the (re)organisation, improvement, development and the evaluation of policy processes, so that a gender equality perspective is incorporated in all policies at all levels and at all stages by the actors normally involved in policymaking" (CoE 1998: 12). Diese Definition wird von vielen Gender Budget-Initiativen als guter Ansatzpunkt gesehen, die Aspekte und Anforderungen an Gender Budgeting gehen jedoch zumeist über ein reines Gender Mainstreaming der Finanzpolitik hinaus (vgl. Kapitel 3.2). Zudem ist das Demokratisierungspotential von Gender Mainstreaming eher umstritten (vgl. u.a. Walby 2005: 332, Beveridge et al 2000: 390f) und wird gerade im Zusammenhang mit der EU äußerst skeptisch betrachtet. Denn zum einen war bei den Urhebern des Gender Mainstreamings von Demokratisierung ,nie die Rede“" (SchunterKleemann 2001: 16) und zum anderen treten gerade supranationale „Machtzentren des Kapitalismus" (ebd.), wie die EU-Kommission, die darüber hinaus auch ,noch heute vergleichsweise geschlossene Männerbastionen darstellen“ (ebd.) also wichtige Impulsgeber der Gender Mainstreaming Debatte auf. Außerdem bleibt den von Entscheidungsprozessen Betroffenen aufgrund der Bürokratisierungs-, Technokratisierungs- und Professionalisierungstendenzen von Gender Mainstreaming Partizipation zumeist verwehrt. Jedenfalls geht es bei Gender Mainstreaming bestenfalls um prozedurale Gerechtigkeit innerhalb einzelner Organisationen oder Verwaltungen, nicht jedoch ,um materielle Verteilungsgerechtigkeit der Gesellschaft als Ganzes. Auch von daher ist in Frage zu stellen, dass Gender Mainstreaming ein ernsthaftes Konzept der Demokratisierung" (SchunterKleemann 2006: 58) sein kann. Demgemäß verstehe auch ich für die vorliegende Arbeit 
Kommission für eine Verbreitung von Gender Budgeting-Initiativen (vgl. Sharp 2003: 6, Michalitsch 2005: 16).

Auf EU-Ebene wurde die Diskussion zum Thema Öffentliche Haushalte und Geschlechterperspektive im Oktober 2001 durch eine von der belgischen Präsidentschaft organisierte Konferenz zum Thema „Gender Responsive Budgeting: a Global Vision to Strengthen Economic and Financial Governance" in Zusammenarbeit mit der OECD, UNIFEM und dem Nordischen Ministerrat eingeleitet. Im Rahmen dieser Konferenz wurde ein Communiqué verabschiedet, in diesem wurde festgehalten, dass Gender Budgeting ein wichtiges Instrument „for strengthening economic and financial governance and for promoting accountability and equality" ist und dass es das Ziel ist, durch politische und finanzielle Unterstützung die Kapazitäten der Regierungen zu stärken ,as well as civil society organizations to carry out these initiatives and to support the global vision of gender responsive budget initiatives in all countries by $2015^{\prime 22}$.

Im Jahr 2002 setzte die Europäische Kommission eine Gender Budgeting-ExpertInnengruppe zur Erhebung sämtlicher Gender Budgeting-Initiativen in den einzelnen EU-Mitgliedsstaaten ${ }^{23}$ sowie zur Förderung der „Umsetzung von Gender Budgeting in EU-Gesamthaushaltsplan sowie nationalen Budgets" (Michalitsch 2003: 233) ein. Diese ExpertInnengruppe erarbeitet des Weiteren Richtlinien für Gender Budgeting in den einzelnen Mitgliedsstaaten, um ,damit Informationen für nationale Regierungen bereitzustellen und diese für geschlechterspezifische Budgetpolitik zu sensibilisieren" (Michalitsch 2005: 16) ${ }^{24}$.

In Europa gab es jedoch auch schon Ende der 1980er Jahre ein Gender Budgeting-Vorreiterin: Seit 1989 erarbeitet und veröffentlicht in Großbritannien die Women's Budget Group (WBG) als unabhängige, zivilgesellschaftliche Organisation jährliche Kommentare zum Budget. Die Women's Budget Group versteht sich selbst als ein ,think tank on the relationship between women, men and economics" (Hill 2002: 171) und besteht aus Feministinnen, Ökonominnen und Ex-

die Definition von Gender Budgeting durch Gender Mainstreaming nicht als forschungsleitend.

22 Dokument unter http://www.gender-budgets.org/content/view/195/154/ abrufbar.

23 Im Dezember 2002 wurden an alle Mitgliedstaaten Fragebogen zu Gender BudgetInitiativen in ihrem Staat ausgeschickt. Dieser brachte nur sieben positive Antworten aus Deutschland, Finnland, Frankreich, Kroatien, Norwegen und Österreich. Die meisten gaben an, Pilotprojekte durchzuführen oder befanden sich im Planungsstadium. Bekanntermaßen gab es jedenfalls Ende 2002 sowohl in Großbritannien als auch in Schweden bereits Gender Budget-Initiativen, der Fragebogen wurde von diesen jedoch nicht beantwortet (vgl. Michalitsch 2005: 16, CoE 2005: 8).

$24 \mathrm{Vgl}$. hierzu auch den Gender Budgeting-Endbericht der ExpertInnengruppe (EG-S-GB) unter http://www.coe.int/T/E/Human_Rights/Equality/PDF_EG-S-GB(2004)RAPFIN_E .pdf. 
pertinnen für Sozialpolitik aus verschiedenen NGOs, Universitäten und anderen Forschungseinrichtungen sowie aus Gewerkschaften. Die WBG wurde 1989 gegründet, ,when a number of feminist women, mainly academics, got together to discuss the implications of the relationship between gender relations and macro economic policy” (Hill 2002: 173). Ursprüngliche Absicht war „to provide critical public commentary on the budget's impacts on women under the Thatcher government's neoliberal agenda" (Sharp 2003: 5). Während der ersten acht Jahre trafen sich die Mitglieder der WBG als informelle Gruppe um auf jährlicher Basis das britische Budget zu kommentieren. Resonanz gab es jedoch kaum, weder von der konservativen Regierung noch von den Medien. Durch den Regierungswechsel und die Machtübernahme der Labour Party im Jahr 1997, „both the extent and the form of engagement with the budgetary process changed dramatically" (Hill 2002: 173). Die WBG gewann an Einfluss, denn mit Hilfe des Cabinet Office's Women and Equality Unit erreichte sie ein Treffen mit dem Finanzministerium (HM Treasury). Dieser mittlerweile regelmäBigen Kontakt zum Finanzministerium - ein ,critical but constructive dialogue” (Elson 2004: 5) - findet ,pre- and post-budget, but also in a series of policy seminars and roundtable meetings on a range of policy issues" (Hill 2002: 173) statt.

Das Hauptziel der Women's Budget Group ${ }^{25}$,has been to persuade British treasury ministers to produce a gender-impact assessment of the annual national budget and to consider, at every stage of policy formulation, the gender implications of their economic policies" (Himmelweit 2002: 49). Hierbei geht es nicht nur darum den Anstoß zu Gender Budgets zu geben, sondern die Regierung auch bei den Gender-Analysen zu unterstützen. Die WBG „konzentriert sich dem britischen Budget-Verständnis entsprechend auf Steuern und Transfers“" (Michalitsch 2003: 233) und deren Auswirkungen auf Frauen und Männer und nicht so sehr auf die geschlechterspezifischen Effekte der öffentlichen Ausgaben (vgl. Sharp 2003: 5f, Hill, 2002: 175). Denn die jährlichen Budgeterklärungen bestehen in Großbritannien nur aus den Änderungen von Steuern und öffentlichen Transfers und jenen Regulierungen, die diese betreffen, und nicht wie in den meisten Ländern aus einem Statement zu den öffentlichen Einnahmen und Ausgaben (vgl. BEIGEWUM 2002: 51, Fußnote 1 und Hill 2002: 175).

\subsubsection{Gender Budgeting in Österreich}

Auch in Österreich fand eine erste eingehende Beschäftigung mit Gender Budgeting auf zivilgesellschaftlicher Ebene statt.

25 Nähere Informationen zur Arbeit der Women's Budget Group sind unter http://www.wbg. org.uk/ zu finden. 
Zum Ende der 1990er Jahre gab es „Einzeldiskussionen bzw. Einzelarbeiten zum Thema Budgets und deren unterschiedliche Auswirkungen auf Frauen und Männer" (Mayrhuber 2006: 24).

Im Umfeld des BEIGEWUM ${ }^{26}$ wurde im Jahr 2000 durch Christa Schlager und Christine Mayrhuber ein Arbeitskreis bestehend aus Wirtschafts- und Sozialwissenschafterinnen von Universitäten, Forschungsinstitutionen, der Verwaltung und Interessensvertretungen zum Thema Budget und Frauen initiiert. Ziel dieses Arbeitskreises war es, „Gender Budgeting in Österreich bekannt zu machen, das Thema in die österreichische politische Debatte einzubringen und die Regierung an ihre Verpflichtungen in diesem Zusammenhang zu erinnern" (Klatzer 2004: 13). Die aus diesem Arbeitskreis hervorgegangen Publikationen, sowie dessen Lobbying-Arbeit für Gender Budgeting haben in den letzten zwei bis drei Jahren dazu geführt, dass zunehmend öffentliche Aktivitäten zu verzeichnen sind, weshalb der Arbeitskreis mittlerweile verstärkt im Sinne eines Gender BudgetingBeirates, als Watchgroup. Gender \& Öffentliche Finanzen ${ }^{27}$, weiterarbeitet (vgl. Klatzer 2004: 16).

In jüngster Vergangenheit haben sich auch österreichische Regierungen auf Bezirks-, Gemeinde-, Landes- und Bundesebene des Themas angenommen. So sind bis dato ,in Österreich einige Projekte und Initiativen zum Gender Budgeting vorhanden" (Mayrhuber 2006: 23). Im Folgenden werde ich einen Überblick über diese Initiativen geben. Es ist hierbei jedoch anzumerken, dass nicht alle Gender Budgeting-Aktivitäten, die auf Verwaltungsebene stattfinden, öffentlich einsehbar sind, weshalb meine Darstellung keinerlei Anspruch auf Vollständigkeit erhebt, sondern vielmehr die Vielzahl der Ansätze skizzieren soll.

Auf Bundesebene wurde in einem Ministerratsvortrag vom 9. März 2004, der von den Regierungsmitgliedern „zur Kenntnis“ genommen wurde, Gender Budgeting zur Analyse von budgetären Maßnahmen hinsichtlich deren Auswirkungen auf Frauen und Männer empfohlen. Hiermit wurde als „Metaziel die Berücksichtigung der Geschlechterperspektive in allen budgetpolitischen Maßnahmen der Ministerien definiert" (Jauk 2007: 1) und zur Umsetzung im Rahmen der interministeriellen Arbeitsgruppe Gender Mainstreaming auch eine Arbeitsgruppe zu Gender Budgeting bestehend aus BudgetistInnen und Gender Main-

26 Der Beirat für gesellschafts-, wirtschafts- und umweltpolitische Alternativen (BEIGEWUM) ist ein, im Jahr 1985 gegründeter Verein österreichischer SozialwissenschafterInnen unterschiedlicher Disziplinen, deren gemeinsames Ziel die Einbringung von Ergebnisse kritischer Forschungstätigkeiten in den laufende politischen Diskurs ist (siehe dazu genauer http://www.beigewum.at)

27 Nähere Informationen zur Watchgroup. Gender \& Öffentliche Finanzen unter http://www. beigewum.at/TCgi/ TCgi.cgi?tar-get=home\&P_Kat=10. 
streaming-Beauftragten aller Ressorts eingerichtet. In Folge dessen entwickelten sich einige Aktivitäten, vor allem Pilotstudien und -projekte in den einzelnen Ministerien ${ }^{28}$.

Exemplarisch möchte ich hier die Pilotuntersuchung im Bereich Drogenpolitik anführen (vgl. Gubitzer et al 2006), die vom damaligen Bundesministerium für Gesundheit und Frauen beauftragt wurde. Als Teil dieses Pilotprojekts wurde auch eine Leitfaden erarbeitet, der den Mitarbeiterinnen und Mitarbeitern der Verwaltung eine anschauliche Einführung und Begriffsklärung zu „Gender Budgeting geben und praktische Beispiele, Instrumente und Herangehensweisen zur Arbeit mit Gender Budgeting darstellen“(Jauk 2007: 2) sollen.

Außerdem soll hier auch die gerne als erste Gender Budgeting-Arbeit auf Bundesebene bezeichnete Studie des Bundesministeriums für Finanzen mit dem Titel „Ist das österreichische Steuersystem tatsächlich ,geschlechtsneutral'?“ aus dem Jahr 2002 nicht unerwähnt bleiben, die - nicht ganz ihrem Titel entsprechend - eine Analyse der geschlechtsspezifischen Auswirkungen von Lohnsteuer und Sozialversicherung beinhaltet und unter dem Titel „Ist die Einkommensbesteuerung geschlechtsneutral?“ im Jahr 2006 zuletzt aktualisiert wurde ${ }^{29}$.

Auf Länderebene finden sich zum derzeitigen Zeitpunkt ebenfalls einige Ansätze, Pilotstudien und -projekte zu Gender Budgeting. Exemplarisch seien hier die Initiative in Oberösterreich und diejenige in Wien genannt. Im Zuge des Projekts „Gender Budget-Analyse in Oberösterreich“ wurden die Ausgaben der Bereiche Bildung, Gesundheit und Sport des (Rechnungsabschlusses für das Jahr 2003 und des Voranschlags für das Jahr 2004 des) Landesbudgets aus einer Geschlechterperspektive überprüft. Die Pilotstudie ${ }^{30}$ umfasste die Erarbeitung eines Katalogs geschlechtsspezifischer Analysekriterien und -indikatoren, die Klärung

28 Genauere Ausführungen zu den Aktivitäten auf Bundesebene sind in der Zusammenstellung „Gender Budgeting, Beispiele aus Österreich“" von Vera Jauk (Bundeskanzleramt, Frauensektion) für die Europäischen Fachkonferenz im Zuge der deutschen Ratspräsidentschaft „Gender Budgeting: Die Verteilung macht's - Gleichstellung und soziale Gerechtigkeit durch geschlechtersensible Haushalte“" am 4./5.Juni 2007 in Frankfurt am Main zu finden.

29 Die Studien sind unter https://www.bmf.gv.at/Finanzministerium/GenderMainstreaming/ gender.pdf (2002) und https://www.bmf.gv.at/Finanzministerium/GenderMainstreaming/ WP_2_2006.pdf (2006) abzurufen.

30 Die Pilotstudie des Österreichischen Instituts für Wirtschaftsforschung und Solution, durch Christine Mayrhuber, Michaela Neumayr, Margit Schratzenstaller, Birgit Buchinger und Ulrike Gschwandtner, im Auftrag des Amtes der Oberösterreichischen Landesregierung, unter Mitarbeit von Hedwig Lutz sowie der Konsulentinnen Luise Gubitzer, Elisabeth Klatzer und Gabriele Michalitsch kann unter http://www.land-oberoesterreich .gv.at/cps/rde/xbcr/SID-3DCFCFC3-A31257A2/ooe/Gender_Budget_Final_Langfassung. pdf abgerufen werden. 
der Datengrundlagen und -beschaffung, außerdem eine Analyse des Ist-Zustandes sowie die Ausarbeitung eines Maßnahmenbündels zur Beseitigung beziehungsweise Verringerung bestehender geschlechtsspezifischer Disparitäten (vgl. Schratzenstaller et al 2006: 38ff).

In Wien gibt es seit einer Landesregierungsklausur im Jänner 2005 den Beschluss zur Einführung von Gender Budgeting. Im Zuge dessen wurde in der Finanzverwaltung eine Gender Budgeting-Beauftragte eingesetzt, die gemeinsam mit den BudgetkoordinatorInnen der einzelnen Geschäftsgruppen seit dem Voranschlag 2006 das Wiener Landesbudget um Gender Budgeting ergänzt.

Seit dem 1. August 2005 ist Gender Budgeting außerdem in der Geschäftseinteilung des Magistrats als Aufgabe der Magistratsabteilung 5 - Finanzwirtschaft, Haushaltswesen und Statistik verankert. Im Zuge der Voranschlags- und der Rechnungsabschlusserstellung sichten die BudgetkoordinatorInnen die Ausgaben ihrer jeweiligen Geschäftsgruppen anhand von Kriterien einer GenderAnalyse (vgl. Voranschlag 2006 und $2007^{31}$ ).

Auch auf Gemeindeebene und Bezirksebene finden sich eine Anzahl von Gender Budgeting-Initiativen mit unterschiedlichen Absichtserklärungen, Konkretisierungsstufen, Vorgehensweisen und Arbeitsfortschritten (vgl. u.a. Mayrhuber 2006: 33, Klatzer 2004: 19ff, Jauk 2007: 7f).

Zusammenfassend können zu den österreichischen Gender Budgeting-Initiativen, ungeachtet ihrer Fortschritte und der möglichen Frage inwieweit einige dieser Initiativen tatsächlich als Gender Budget-Initiativen bezeichnet werden können, zwei wesentliche Charakteristika identifiziert werden: Erstens sind es auf der Prozessebene ausschließlich ExpertInnen- seien es externe WissenschafterInnen oder interne Budgetverantwortliche - denen die Erarbeitung der Gender Budgeting-Studien übertragen wurde. Und zweitens ist auf inhaltlicher Ebene festzuhalten, dass sich die österreichischen Ansätze fast ausnahmslos auf Analysen der Ausgabenseite der ihnen zugrunde liegenden Budgets beziehen beziehungsweise beschränken.

\subsubsection{Standortbestimmung der Demokratisierungspotentiale - Gender Budgeting in Wien}

Um das Demokratisierungspotential von Gender Budgeting sowie seinen Beitrag zu einer Demokratisierung der Wirtschaftspolitik genauer zu analysieren, werde ich im Folgenden die Wiener Gender Budget-Initiative untersuchen. Hierbei handelt es sich - wie beim Partizipativen Budget in Porto Alegre (siehe Kapitel 3.1) - um das Budget einer Landeshauptstadt und vergleichbar mit dem Partizi-

31 Diese sind unter http://www.wien.gv.at/finanzen/budget/va07/pdf/31.pdf und http://www. wien.gv.at/finanzen/ budget/va07/pdf/32.pdf einzusehen. 
pativen Budget wurde das Hauptaugenmerk auf die Ausgabenseite des Budgets gerichtet. Allerdings gibt es in Wien keine lange Tradition von Gender Budgeting oder ähnlichen Demokratisierungsbestrebungen der Wirtschaftspolitik wie die des Partizipativen Budgets in Porto Alegre. Auch hinsichtlich der Auswirkungen von und Veränderung durch Gender Budgeting sind nur kurzfristige Aussagen zu treffen, da noch keine langfristige Daten vorhanden sind.

Als Ausgangspunkte werden auch hier die drei Dimensionen beziehungsweise Vektoren dienen, die für eine Demokratisierung der Wirtschaftspolitik beachtet werden müssen: der Input, also die Beteiligungsmöglichkeiten von Bürgerinnen und Bürgern an wirtschaftspolitischen Entscheidungsprozessen und Aktivitäten, der Output, also die Inhalte von Wirtschaftspolitik und deren Anreicherung mit Gerechtigkeitsüberlegungen, sowie die Institutionen (vgl. Kapitel 3 und 3.1.3).

\subsection{Input Mitbestimmung und Beteiligung}

Den ersten Schritt der Beschäftigung mit Gender Budgeting machte die Wiener Verwaltung mit der von der Frauenabteilung organisierten und durch die Frauenstadträtin ebenso wie den Finanzstadtrat unterstützten Enquete „Gender Budgeting - Wege zur geschlechtergerechten Verteilung öffentlicher Gelder und Leistungen" am 15. Dezember 2004. Die Frauenabteilung der Stadt Wien (MA 57) war laut Geschäftseinteilung für den Magistrat seit dem 1. Jänner 2000 koordinierende Stelle für Gender Mainstreaming und intendierte mit dieser Veranstaltung Verwaltung sowie KommunalpolitikerInnen über „Gender Budgeting als finanzpolitischer Aspekt des Gender Mainstreaming“ zu informieren. Als Resultat dieser Enquete beschloss die Wiener Landesregierung im Jänner 2005 den „Ausbau von Gender Mainstreaming um Gender Budgeting ${ }^{، 32}$ und bestellte eine Mitarbeiterin der Finanzverwaltung gemeinsam mit den BudgetkoordinatorInnen der Geschäftsgruppen ${ }^{33}$ zu Gender Budgeting-Beauftragten.

Im Juli 2005 wurde Gender Budgeting dann in der Geschäftseinteilung verankert und der Abteilung Finanzwirtschaft, Haushaltswesen und Statistik (MA 5) zugewiesen. Der Budgetvoranschlag für das Jahr 2006 enthielt erstmals ein eigenes Kapitel zu Gender Budgeting, indem die einzelnen Geschäftsgruppen über ihre Gender Mainstreaming-Aktivitäten beziehungsweise oftmals über ihre Frauen-

32 Die beiden aufeinander folgenden Zitate sind der Homepage der Projektstelle Gender Mainstreaming (unter http://www.wien.gv.at/menschen/gendermainstreaming/beispiele/bu dgeting.html abrufbar) entnommen.

33 Geschäftsgruppe 0: Magistratsdirektion, Geschäftsgruppe 1: Integration, Frauenfragen, KonsumentInnenschutz und Personal, Geschäftsgruppe 2: Finanzen, Wirtschaftspolitik und Wiener Stadtwerke, Geschäftsgruppe 3: Bildung, Jugend, Information und Sport, Geschäftsgruppe 4: Kultur und Wissenschaft, Geschäftsgruppe 5: Gesundheit und Soziales, Geschäftsgruppe 6: Stadtentwicklung und Verkehr, Geschäftsgruppe 7: Umwelt, Geschäftsgruppe 8: Wohnen, Wohnbau und Stadterneuerung. 
förderungsmaßnahmen berichteten. Hierfür versandten die BudgetkoordinatorInnen im Zuge der Erstellung des Voranschlagsentwurfes jeweils an die BudgetreferentInnen ihrer Geschäftsgruppen angehörenden Abteilungen Formulare und baten um eine Bewertung der jeweiligen geplanten Ausgaben der Abteilungen. Die BudgetkoordinatorInnen fungierten als Informations-, Beratungssowie als Sammelstelle.

Parallel mit der Implementierung von Gender Budgeting wurde im Jahr 2005 der Bereich des Gender Mainstreaming aus der Frauenabteilung ausgegliedert und mit Erlass des Magistratsdirektors vom 28. September 2005 die Projektstelle Gender Mainstreaming in der Magistratsdirektion - Geschäftsbereich Organisation und Sicherheit, Gruppe Organisation eingerichtet. Diese Projektstelle versteht sich als die Schnittstelle für eine strukturierte und flächendeckende Implementierung von Gender Mainstreaming im Magistrat und arbeitet mit den Gender Budgeting-Beauftragten zusammen, da Gender Budgeting in ,enger Abstimmung mit Gender Mainstreaming" (Voranschlag 2006: 259) implementiert werden soll (vgl. hierzu die Homepage der Gender Mainstreaming Projektstel$\mathrm{le}^{34}$ ebenso wie die Wiener Voranschläge 2006 und 2007).

Zusammenfassend kann festgehalten werden: Die Wiener Gender BudgetingInitiative ging von der Frauenabteilung aus und ist charakterisiert durch eine sehr starke Verknüpfung mit Gender Mainstreaming ${ }^{35}$. Für die Implementierung von Gender Budgeting wurde die Aufgabe in der Finanzverwaltung verankert und dort eine Gender Budgeting-Beauftragte bestimmt. Zum einen wurden auBerdem die neun BudgetkoordinatorInnen der einzelnen Geschäftsgruppen sowie die jeweiligen BudgetreferentInnen in den einzelnen Abteilungen für Gender Budgeting zuständig gemacht. Diese sind allesamt FinanzexpertInnen und verfügen über kein bis kaum Wissen zu Gender und Geschlechtergerechtigkeitsfragen. Daher besteht eine enge Zusammenarbeit mit der Gender Mainstreaming-Projektstelle. An der Erstellung des Gender Budget-Kapitels im Voranschlag und mittlerweile auch im Rechnungsabschluss arbeiten also ausnahmslos verwaltungsinterne FinanzexpertInnen, die sich um nähere Informationen, Schulungen und Hilfe zu Gender-Fragen bei der Projektstelle melden können. Verwaltungsexterne - wie Privatpersonen, zivilgesellschaftliche Initiativen, aber auch weitgehend die Mitglieder der Wiener Landesregierung - haben vor der Veröffentlichung des Budgetvoranschlags beziehungsweise des Rechnungsabschlusses weder Einblick in die vorangegangenen Arbeiten oder Ausführungen und können nichts zum Gender Budgeting-Prozess beitragen oder einbringen.

34 http://www.wien.gv.at/menschen/gendermainstreaming/

35 Siehe zur Diskussion um Gender Mainstreaming und dessen umstrittenes Demokratisierungspotential Fußnote 21 auf Seite 68. 
Es kann also eine gewisse Diskrepanz zwischen dem partizipativen Anspruch von Gender Budgeting per definitionem und der Praxis in der Wiener Verwaltung festgestellt werden. Diese Kluft konnte auch Debbie Budlender in ihrer Untersuchung der Wirkungen ausgewählter Gender Budget-Initiativen des Südens aus dem Jahr 2004 feststellen. Sie unterstreicht: „There is often slippage in discussions of ,progressive' budget work in that GRB work is assumed, by definition, to involve a more participatory approach" (Budlender 2004: 21). Und erklärt dies damit, dass erstens eine stärkere politische Partizipation von Frauen nicht zwangsweise in einer größeren Aufmerksamkeit für Gender-Probleme oder Fraueninteressen resultieren muss ,although - overall - it is likely to do so" (ebd.: 22). Zweitens besteht die Henne-Ei-Frage, ob eine stärkere politische Partizipation von Frauen Gender Budget-Initiativen hervorbringt oder die Arbeit der Gender Budget-Initiativen eine stärkere politische Partizipation forciert. Drittens muss geklärt werden ob die Partizipation in der Verwaltung, im Parlament oder in der Zivilgesellschaft gemeint ist.

So kann gerade anhand des Beispiels der Wiener Gender Budget-Initiative gezeigt werden, wie ein unterschiedliches Verständnis von Partizipation vollkommen verschiedene Ergebnisse der Partizipation von Frauen bringen kann: Wird auf die Partizipation von Frauen in der Verwaltung fokussiert, so sind an der Gender Budget-Erstellung annähernd gleich viele Frauen wie Männer beteiligt ${ }^{36}$. Wird Partizipation jedoch als möglichst optimale Beteiligung von Bürgerinnen und Bürgern an politischen Entscheidungsprozessen und Aktivitäten verstanden, so sind überhaupt keine Frauen (jedoch auch keine Männer) eingebunden. Ein solch enges Verständnis von Partizipation beschränkt auf verwaltungs- beziehungsweise regierungsinterne Frauen oder eingeladene externe Expertinnen, resultiert zumeist - wie auch in Wien - darin, dass eine Partizipation ausschließlich auf AkademikerInnen, Think-tanks und VerwaltungsmitarbeiterInnen eingeschränkt ist, die nicht notwendigerweise Themen wie den Demokratisierungsanspruch von Gender Budgeting auf die Agenda bringen werden. Hierdurch verschwindet der Anspruch und Ausgangspunkt von Gender Budgeting, eine „Herbeiführung von Veränderungen bei Politiken und Budgeterstellungsprozessen im Sinne einer Verbesserung der sozialen und wirtschaftlichen Stellung von Frauen und mehr Gendergerechtigkeit durch stärkere Partizipation der Betroffenen" (Mayrhuber 2006: 35) zu erwirken. Weiterhin werden einzelnen Akteurinnen und Akteuren unterschiedliche Möglichkeiten und informelle Kanäle der Partizipation eröffnet, die Zugangsmöglichkeiten zum Budgetprozess bleiben erratisch

36 Die BudgetkoordinatorInnen setzen sich aus 44\% Frauen und 56\% Männern zusammen, die BudgetreferentInnen aus $47 \%$ Frauen und $53 \%$ Männern, zusätzlich dazu sind die Gender Budget-Beauftragte und die Leiterin der Projektstelle Gender Mainstreaming in den Prozess eingebunden, was einen Gesamtfrauenanteil von 49\% und einen Gesamtmänneranteil von $51 \%$ ergibt (Stand September 2007). 
und hängen von verschiedenen Macht- und Einflussfaktoren ab. Damit gibt es keine Transparenz und der Budgeterstellungsprozess entzieht sich der Rechenschaftspflicht sowohl auf Seiten der Regierung wie auf Seiten der Begünstigten (vgl. Klatzer 2003: 200f). Da jedoch gerade eine möglichst weitgehende Partizipation von Frauen wesentlich ist "to ensure that the diversity of women's interests is represented and that these initiatives do not become mere technical exercises" (Raes 2006: 4), wird in Zukunft ein Focus auf den Input des Wiener Budgetprozesses und somit auf die Mitbestimmung durch und Beteiligung von Bürgerinnen und Bürgern gelegt werden müssen, denn ,a clear policy focus and strong links with existing actions and mechanisms for the advancement of women can limit such risks" (ebd.).

Dennoch ist festzuhalten, dass in Wien überhaupt erst die Präsenz von Frauen in entscheidungsbefugten Positionen die Einführung von Gender Budgeting innerhalb der Verwaltung ermöglicht hat. Eine politische Repräsentation von Frauen scheint eine förderliche Rahmenbedingung für Gender Budget-Initiativen darzustellen, kann diese jedoch keineswegs garantieren. Vielmehr ist es zumeist die Präsenz von starken Frauen in Führungspositionen, die das Potential von Gender Budgets erkannt haben und gewillt sind, für solche Initiativen zu kämpfen und Mühe in die Arbeit stecken um die Initiativen dann auch zu erhalten (vgl. auch Budlender 2004: 24). Demgemäß ist in Wien die Einführung von Gender Budgeting sicherlich der Verdienst einer starken Frauenabteilung und einer engagierten Frauenstadträtin gewesen.

Des Weiteren ist anzumerken, dass für eine verstärkte Beteiligung von Bürgerinnen in der Wiener Initiative gerade ihre Ansiedelung auf lokaler Ebene äußerst erfolgversprechend wäre. Denn lokale politische Entscheidungen betreffen grundsätzliche und alltägliche Sachverhalte, die für Frauen und ihre Familien direkter von Belang sind, wodurch sich vor allem Bürgerinnen eher daran beteiligen als an den ,großen“" politischen Themen. Außerdem ist es für Frauen zumeist aufgrund ihrer häuslichen und familiären Verpflichtungen und Bindungen einfacher auf nachbarschaftlichen, lokalen als auf regionalem und nationalem Niveau zu partizipieren (vgl. hierzu auch Kapitel 3.1.3.1).

\subsection{Institutionen}

Da der Inputaspekt, die Mitbestimmung und Beteiligung von Bürgerinnen und Bürgern bislang kein Thema der Wiener Gender Budget-Initiative ist (vgl. Voranschlag 2006 und Rechnungsabschluss 2006), werden hier auch mögliche Institutionen, die eine Mitbestimmung und Beteiligung forcieren könnten, nicht explizit konzipiert.

Auch auf theoretischer Ebene gibt es nur wenige Überlegungen, welcher Institutionen Gender Budgeting bedarf, um dem Demokratisierungsanspruch gerecht werden zu können und eine möglichst optimale Beteiligung von Bürgerinnen 
und Bürgern am Budgetprozess gewährleisten zu können - obgleich es in wissenschaftlichen Arbeiten zu Gender Budgeting den gemeinsamen Anspruch gibt, dass Gender Budgets „kein technokratisches Instrument sein [sollen], bei dem sich einige spezialisierte ExpertInnen stellvertretend für Frauen Gedanken über das Budget machen“ (BEIGEWUM 2002: 190).

Erste Überlegungen stammen in Österreich aus dem Arbeitskreis Budget und Frauen im Umfeld des BEIGWUM, der darauf hinwies, dass ein impliziter Bestandteil von Gender Budgets die Einbeziehung einer möglichst breiten Öffentlichkeit in die Planungs- und Entscheidungsprozesse sein sollte. Dies bedarf einer breiten, verständlichen ebenso wie gleichstellungsrelevanten Information der Bevölkerung über budgetpolitische Fragestellungen: „Es müssen Schritte gesetzt werden, um vermehrt zivilgesellschaftliche Initiativen und engagierte Einzelfrauen und -männer für die Thematik zu interessieren, sie zu aktivieren und mit einzubeziehen" (ebd.: 190). Innerhalb bestehender Entscheidungsinstitutionen wäre ein „erster wichtiger Schritt, mehr Frauen einzubinden. Dabei geht es nicht um die Beiziehung einiger ,Alibifrauen' sondern um eine adäquate formale Vertretung von Frauen in den entsprechenden Entscheidungsgremien“ (ebd.: 191). Da eine verstärkte Beteiligung von Bürgerinnen und Bürgern nicht automatisch bedeutet, dass mehr Frauen in die Entscheidungsprozesse eingebunden werden und/oder gleichstellungspolitische Fragestellungen verfolgt werden, „müssen Partizipationsbesterbungen, Informationen, Diskussionsrunden etc so gestaltet werden, dass die Bedürfnisse von Frauen in materieller und prozessbezogener Hinsicht Berücksichtigung finden" (ebd.).

Zugang zu und Präsenz in politischen Prozessen sind zwar wesentliche Elemente, aber auch die Frage des Einflusses von Frauen ist entscheidend mitzuberücksichtigen. „Die Möglichkeit des Einflusses hängt von der Ausgestaltung der Institutionen und deren Verantwortlichkeit beziehungsweise Rechenschaftspflicht gegenüber den Gender politischen Zielsetzungen ab" (Klatzer 2003: 291f). In einem weiteren Schritt sollten alle „relevanten Gesetze und Bestimmungen, die den Budgetprozess regeln (...) in Zusammenarbeit mit der Zivilgesellschaft überarbeitet werden: denn von der demokratischen Ausgestaltung des Budgetprozesses hängt es ab, durch wen und wessen Kritik, Empfehlungen, Forderungen und Inhalte in das Budget aufgenommen werden" (BEIGEWUM 2002: 192).

Idealtypisch sollte jedenfalls auf jeder Ebene des Budgetprozesses eine Beteiligung der Bürgerinnen und Bürger vorgesehen sein, vorrangig auf den drei Ebenen der ,preference revelation, conflict resolution and impact evaluation (...) If participation does occur in all three stages, this will enable people to hold the authorities accountable by comparing the outcomes of the budgetary process with the stated goals in which the people themselves had a say" (Osmani 2002: 240f). 


\subsection{Output: Geschlechter- und Verteilungsgerechtigkeit}

Das Ziel von Gender Budget-Initiativen ist ein verbesserter Einsatz öffentlicher Ressourcen hinsichtlich mehr Geschlechtergerechtigkeit, daher darf nicht ausschließlich die Eingabeseite der politischen Prozesse, also der politisch-demokratischen Input, betrachtet werden sondern ebenso die Outputseite ${ }^{37}$.

Folglich stellt sich für die Wiener Initiative die Frage inwieweit (Geschlechter-) Gerechtigkeitsüberlegungen in den Budgeterstellungsprozess eingeflossen sind und welche Veränderungen auf die Politiken der Landesregierung zu verzeichnen waren. $\mathrm{Zu}$ beachten ist hierbei, dass aufgrund der sehr viel kürzeren Tradition als der achtzehnjährigen des Partizipativen Budgets in Porto Alegre nur kurzfristige Wirkungen und Veränderungen zu finden sind. Dennoch wird im Wiener Voranschlag 2006 daraufhin gewiesen, dass im Rechnungsabschluss „dann explizite Veränderungen dargestellt werden“ (Voranschlag 2006: 275) sollen. Demgemäß möchte ich im Folgenden den Voranschlag und den Rechnungsabschluss des Jahres 2006 hinsichtlich Veränderungen aufgrund von Gender Budgeting untersuchen. Vorwegzunehmen ist, dass für den Voranschlag andere Formulare als für den Rechnungsabschluss verwendet wurden und unterschiedliche Aspekte abgefragt wurden ${ }^{38}$. Dies ermöglicht kaum bis keine Vergleichbarkeit. Während sich der Voranschlag ausschließlich auf ein Aufzeigen

37 Beispielsweise ging auch die Gender Budgeting-Pionierinitiative in Australien aus Initiativen der Verwaltung hervor und konnte kaum eine Beteiligung der Zivilgesellschaft beziehungsweise von Bürgerinnen und Bürgern verzeichnen. Dennoch wurde sie vielfach als „an example par excellence of the mandarin approach to women's policy" (Summers, 1986: 66 zit. in Sawer 2002: 50) bezeichnet, dessen Stärke in der Kapazität lag Druck auf die Ministerien ausüben zu können, detaillierte geschlechterspezifisch-disaggregierte Daten der direkten und indirekten Wirkungen der Politiken und Programme bereitzustellen um das Budget hinsichtlich mehr Geschlechtergerechtigkeit besser verteilen zu können (vgl. Sharp 2002: 32).

38 Mit Hilfe des Formulars für den Voranschlag 2006 wurden folgende Informationen abgefragt (vgl. Voranschlag 2006: 264):

\begin{tabular}{|c|c|c|c|c|c|c|}
\hline \multirow{2}{*}{$\begin{array}{l}\text { Dienst- } \\
\text { stelle }\end{array}$} & \multirow{2}{*}{$\begin{array}{l}\text { Bezeichnung } \\
\text { (der Dienst- } \\
\text { stelle) }\end{array}$} & \multirow{2}{*}{$\begin{array}{l}\text { (Budget) } \\
\text { Ansatz }\end{array}$} & \multirow{2}{*}{$\begin{array}{l}\text { Aspekt } \\
\text { (Bezeichnung } \\
\text { des Ansatzes) }\end{array}$} & \multicolumn{2}{|c|}{ Anteil in \% } & \multirow{2}{*}{$\begin{array}{l}\text { Anmer- } \\
\text { kungen/ } \\
\text { Quelle }\end{array}$} \\
\hline & & & & Frauen & Männer & \\
\hline
\end{tabular}

Im Vergleich dazu sollten die Dienststelle für den Rechungsabschluss 2006 folgendes Formular ausfüllen (vgl. Rechnungsabschluss 2006: 294):

\begin{tabular}{|l|l|l|l|l|}
\hline $\begin{array}{l}\text { Dienst- } \\
\text { stelle }\end{array}$ & Ansatz & $\begin{array}{l}\text { Gender- } \\
\text { spezifische(s) } \\
\text { Ziel(e) }\end{array}$ & $\begin{array}{l}\text { Erfolgsfaktoren (in dieser } \\
\text { => Umgesetzte } \\
\text { Projekt(e) und } \\
\text { Maßnahmen }\end{array}$ & $\begin{array}{l}\text { Spalte sollten die erzielten } \\
\text { Veränderungen dargestellt } \\
\text { werden, die Bezeichnung } \\
\text { scheint aber missverständlich } \\
\text { gewesen zu sein) }\end{array}$ \\
\hline
\end{tabular}

Anmerkung: die kursiven Textpassagen sind Erkläıungen und Anmerkungen der Autorin. 
der Anzahl von Nutzerinnen und Nutzer - sofern dies datentechnisch möglich war - bezieht, sollten im Rechnungsabschluss geschlechtsspezifische Ziele und umgesetzte Projekte aufgelistet werden. Hierfür gab es jedoch keine gemeinsamen Gleichstellungsziele, an denen sich die einzelnen Abteilungen orientieren und ihre Ziele ableiten hätten können. Die Abgrenzung zu Frauenfördermaßnahmen ist zudem äußerst uneindeutig. Und die politische Zielsetzung oder die politischen Veränderungen, die mit Gender Budgeting erreicht werden sollen, sind sowohl im Voranschlag als auch im Rechnungsabschluss unklar.

Nur anhand von zwei Positionen sind intendierte Veränderungen, die zu mehr Geschlechtergerechtigkeit beitragen sollen, im Voranschlag und Rechnungsabschluss nachvollziehbar dargestellt: In der Magistratsdirektion im Bereich des Betrieblichen Vorschlagswesens wurde im Voranschlag die geringe Zahl der Prämierungen von Vorschlagseinreichungen durch Frauen, also die Ausschüttung weitaus weniger Geldprämien an Frauen als an Männer, aufgezeigt. Zwar erst im Rechnungsabschluss, aber dennoch, wurde das Ziel formuliert den Frauenanteil erhöhen zu wollen. Dies konnte mit Hilfe gezielter Werbe- und Informationsmaßnahmen erreicht werden (vgl. Voranschlag 2006: 263, Rechnungsabschluss 2006: 294).

Im Bereich des Fonds Soziales Wien wurde im Voranschlag das Ziel formuliert neue Wohnplätze für wohnungslose Frauen zu schaffen, da trotz steigender Zahl der wohnungslosen Frauen Wohnplätze bislang hauptsächlich für Männer errichtet wurden. Dementsprechend findet sich im Rechnungsabschluss die Zahl der neuen Wohnplätze für Frauen (vgl. Voranschlag 2006: 271, Rechnungsabschluss 2006: 309).

Gleichstellungspolitisch problematisch erscheint jedoch, dass es weder im Voranschlag noch im Rechnungsabschluss Analysen der mit der Nutzung der öffentlichen Leistungen verbundenen indirekten Nutzungseffekte gibt. Ebenso wenig werden die unbezahlte Arbeit ${ }^{39}$ und die indirekten Wirkungen des Wiener Bud-

39 Wie in Fußnote 2 (auf Seite 17) erarbeitet, ist Gender als "the social meanings given to biological sex differences” konzeptionalisiert (Elson et al 1995: 1828), als die „,socially constituted relations between women and men" (ebd.) und demgemäß als ,a stratifier of social life comparable to other stratifiers such as class, race, and ethnicity" (ebd.). Gender schreibt Frauen und Männer unterschiedliche soziale und ökonomische Rollen als Arbeitskräfte, Familienmitglieder und Teile der Gesellschaft zu und bildet die Basis für die grundlegende Arbeitsteilung zwischen produktiver und reproduktiver Arbeit und damit auch die Basis von Ungerechtigkeiten zwischen den Geschlechtern (vgl. Budlender 2004: 18). Produktive Tätigkeiten bezeichnen einkommensgenerierende Arbeiten, die zumeist mit dem Markt verbunden sind. Reproduktive Tätigkeit inkludieren die unbezahlte Verantwortung für "the care and development of people, including children, the elderly, the sick, and able-bodied adults" (Elson et al 1995: 1828), die in den meisten Kulturen geschichtsübergreifend ausschließlich Frauen zugeschrieben werden. Diese unbezahlte Arbeit beinhaltet auch das ,maintaining the labour force and keeping the social framework 
gets auf unbezahlte Arbeiten thematisiert. Als Hindernis gilt das Fehlen von verfügbaren Daten und Informationen welche unbezahlten Arbeiten von wem geleistet werden. Dabei ist der Fokus auf unbezahlte Arbeit der Schlüsselaspekt, der Gender Budget-Initiativen von anderen (partizipativen) Budget-Initiativen unterscheidet oder unterscheiden sollte, denn Geschlechtergerechtigkeit beziehungsweise die „Auswirkung eines Budgets auf die soziale Gleichstellung von Frauen und Männern zeigt sich in seinem Effekt auf das Maß an unbezahlter Arbeit, die erbracht werden muss" (Elson 2002b: 23). Die Notwendigkeit der Fokussierung unbezahlter Arbeit in Gender Budget-Initiativen ergibt sich also aus ihrer Wichtigkeit als „a basis for gender inequality“ (Budlender 2004: 18). Eine Finanzpolitik, die die nicht-marktliche, unbezahlte, zum größten Teil von Frauen geleistete Arbeit nicht in sämtliche Stadien des Budgetprozesses berücksichtigt und miteinbezieht, kann den Prinzipien von Gender Budgeting nicht gerecht werden.

Die Wiener Gender Budget-Initiative ist nicht die einzige Initiative, die unbezahlte Tätigkeiten nicht berücksichtigt: Budlender kommt in ihrer Studie (siehe hierzu Kapitel 3.2.2.1.1) zu dem Schluss, dass ,despite its importance (...), the unpaid labour aspect is not present in all GRB [Gender Responsive Budgeting] work. And when it is present, it is often not strongly developed" (Budlender 2004: 17). Einige Initiativen berücksichtigen unbezahlte Arbeit überhaupt nicht, andere erwähnen unbezahlte Tätigkeiten zwar in den Analysen des Ist-Zustandes, aber führen die Berücksichtigung jedoch nicht weiter ,when it comes to discussing policy and associated budgets" (ebd.: 18).

Budlender unterstreicht hierbei, dass im Vorhandensein detaillierter Daten zur unbezahlten Arbeit keine Maßgeblichkeit für das in Betracht ziehen von unbezahlter Arbeit durch Gender Budget-Initiativen liegt, denn ,if - as is usually the case - everyone acknowledges that women bear the main burden of most types of unpaid labour, exact data strengthen the case and make it appear more scientific, but are not required for appropriate policy making" (Budlender 2004: 18).

Zusammenfassend ist zu konstatieren, dass Gender Budget-Initiativen sowohl prozesstechnische (also demokratisch input- sowie institutionenbezogene) wie auch inhaltliche (outputorientierte) Rahmenbedingungen benötigen würden, die - wie das Beispiel der Wiener Initiative verdeutlicht - von den gegenwärtigen

in good order - both vital services for the paid economy" (Elson 1999: 3). Noch immer ist in den meisten Gesellschaften die unbezahlte Arbeit zwischen Frauen und Männern ungleich verteilt und wird zumeist als selbstverständlich vorausgesetzt und als unabhängig von der bezahlten Ökonomie dargestellt. „Dies ist eines der Haupthindernisse auf dem Weg zur Gleichstellung bei bezahlter Arbeit und bei der vollen Entfaltung der Talente beider Geschlechter" (Elson 2002b: 23). 
Budgetentscheidungen und -erstellungen abweichen müssten, um den theoretischen Ansprüchen per definitionem in der Praxis entsprechen zu können. Hierbei ist es in einem allerersten Schritt ,eine sowohl nach innen als auch nach außen erkennbare politische Zielsetzung die mit Gender Budgeting erreicht werden soll“ nötig, wenn „eine Neugestaltung der Analysegrundlagen von Budgets im Sinne einer höheren Geschlechtergerechtigkeit nicht zu einer Beschäftigungstherapie für die Verwaltung und Forschung" werden soll (Mayrhuber 2006: 35).

Die Gender Budget-Initiative in Wien lässt jedoch bis zum derzeitigen Zeitpunkt keine eindeutigen politischen Ziele erkennen, weder auf Ebene des demokratisch-politischen Input oder der demokratisch-institutionellen Arrangements und Bedingungen um den Budgetprozess transparenter und partizipativer zu gestalten, noch auf Ebene des politischen Outputs um mit Gender Budgeting Geschlechtergerechtigkeit und eine soziale Gleichstellung der Geschlechter herzustellen. So fand in Wien bis dato zwar eine erste Gender-Sensibilisierung beziehungsweise Gender-Wissensvermittlung der Verwaltung - im Speziellen der FinanzexpertInnen - sowie eine verstärkte Erstellung geschlechtersensibler Statistiken statt. Abgesehen davon blieb die Wiener Gender Budget-Initiative jedoch relativ wirkungslos ${ }^{40}$ und erwirkte kaum bis keine Veränderungen der Budgetprioritäten.

40 Dieses Ergebnis entspricht wiederum (vgl. Kapitel 3.2.2.1.1) zu einem großen Teil den Erkenntnissen Debbie Budlenders, die zusammenfasst, dass „overall, however, the more than fifty GRB initiatives around the world have probably produced relatively few budget changes" (Budlender 2004: 11). Sie begründet diese relative Wirkungslosigkeit von Gender Budgeting-Initiativen folgendermaßen: Zum einen sind Veränderungen von Politiken zum größten Teil Resultat einer Kombination von Kräften und nicht einer einzigen Initiative. Zweitens leiten sich Veränderungen nicht automatisch aus der Präsentation von neuen, besseren Fakten ab: Gender Budget-Initiativen konnten weltweit dort die meisten Veränderungen erzielen, wo sie die Richtungen unterstützten, die Regierungen ohnehin gehen wollten, denn mit Hilfe von Gender Budgets können die Positionen der Regierungen gestärkt und unterstrichen werden. Als dritten Grund nennt sie die relative Machtlosigkeit hinsichtlich tatsächlicher Veränderungen von Budgets derer, die Gender Budgets erarbeiten. Gerade bei denjenigen Initiativen, die von Gender Leitstellen beziehungsweise Beauftragten oder Gender Ministerien ausgehen ist eine Limitation ihrer Macht evident. Denn Gender Beauftragte ,are often too junior to influence decisions" (ebd.: 12), außerdem werden zumeist administratives Personal oder Personalabteilungen zusätzlich mit dem Gender-Thema beauftragt. Diese haben kaum freie Zeit und Energie und wenn doch, dann kaum genug Wissen über oder Macht für eine Re-Allokation öffentlicher Ressourcen. Auch Gender Ministerien haben de facto nur theoretisch genug Machi um andere Ministerien beeinflussen zu können (vgl. ebd.: $11 \mathrm{ff}$ ). 


\subsubsection{Zwischenfazit: Gender Budgeting zugunsten des Partizipativen Budget aufgeben?}

Während das Partizipative Budget in Porto Alegre ,vielfach als gelungenes Beispiel für eine Demokratisierung der Wirtschaftspolitik genannt" (Klatzer 2003: 287) wird, konnten die Gender Budget-Inititativen - so auch die Wiener Initiative - die grundsätzlichen Anforderungen, Ansprüche und Rollen, die an Gender Budgeting gestellt werden, (noch) nicht erfüllen (siehe Kapitel 3.2.2.1.1 bis 3.2.2.1.3). Daher stellt sich die Frage, inwieweit - wenn nach der Demokratisierung von Wirtschaftspolitik gestrebt wird - die Idee des Gender Budgetings nicht zu Gunsten eines Partizipativen Budgets nach dem Vorbild Porto Alegres aufgegeben werden könnte.

In Porto Alegre nahmen am Partizipativen Budget im Zeitablauf grundsätzlich ungefähr gleich viele Frauen wie Männer teil - mit steigender Tendenz der Zahl der Frauen (vgl. Baierle 2002: 7 und Kapitel 3.1.3.1.2). Außerdem wurde der Output des Partizipativen Budgets von Frauen für sie als durchaus positiv empfunden, so zum Beispiel die Verbesserungen der Infrastruktur, hinsichtlich derer eine Repräsentantin des PB-Rates unterstrich, dass insbesondere Frauen von den Asphaltierungen der Straßen profitierten, da die Kleidung der Familienmitglieder weitaus weniger schnell schmutzig wurde und Frauen in ihrer Verantwortung für die Kleiderwäsche entlastet wurden (vgl. Sugiyama 2003: 15).

Auch hierbei erscheint jedoch die Rolle der Frauen prototypisch: Ebenso wie Frauen auf Ebene der allgemeinen BürgerInnenversammlungen weitgehend zu gleichen Teilen wie Männer vertreten sind, jedoch im Vergleich zu Männern kaum in höhere Positionen gewählt werden beziehungsweise sich in diese Positionen wählen lassen (vgl. Baiocchi 2003: 53), hatte das Partizipative Budget unterschiedliche Auswirkungen auf Frauen und Männer - aufgrund deren sozialer Geschlechterrolle. Somit war das Partizipative Budget zwar ,particularly important for women, since they often must compensate for the lack of basic infrastructure by performing double and triple roles" (ebd.: 11), Geschlechtergerechtigkeit oder Frauenfreundlichkeit des Outputs der Politiken, stellte jedoch nie ein Thema des Partizipativen Budgets dar.

Das Partizipative Budget in Porto Alegre ist also ebenso geschlechterblind wie die traditionelle Budgeterstellung davor. Das „PB has not sought explicitly to address gender inequality“ (ebd.), seine Methodologie war von Anfang an dahin ausgerichtet, geographische Ungleichheiten innerhalb der Stadt zu beseitigen, die Herstellung von Geschlechtergerechtigkeit war kein Anliegen. Während das Partizipative Budget zwar Möglichkeiten zur Umverteilung öffentlicher Gelder schuf, implizierte dies keine geschlechtergerechtere oder frauenfreundlichere Allokation der Ressourcen: „Participatory budget processes (...) have not consistently included gender concerns" (Hofbauer-Balmori 2003: 14). Die Rahmenbedingungen einer partizipativen Budgeterstellung garantierten keineswegs per 
se einen geschlechtergerechten partizipativen Prozess oder Output: „Unless the budget process is designed to promote discussion of the gendered impact of the budget, those discussions will seldom occur" (Sugiyama 2003: 11).

Doch ,gender issues have rarely been raised“ (Baierle 2002: 7) - weder auf Ebene des demokratisch-politischen Input, der demokratisch-institutionellen Bedingungen noch auf Ebene des politischen Outputs. Eine Partizipation von Frauen und Männern am Budgetprozess jedoch erwirkt nicht automatisch geschlechtergerechte Partizipationsmöglichkeiten oder politische Outputs, wie beispielsweise eine geschlechtergerechtere Verteilung der Ausgaben. Denn ebenso wie bei allen anderen politisch-demokratischen Formen, stellt sich auch in partizipativen Strukturen und Institutionen das Problem der ,underlying gender relations and processes designed for the participation of traditional players (men), under traditional ,rules of the game' [that] allow little space for women who are not already empowered" (Hofbauer-Balmori 2003: 36). Es gab auch keine expliziten Ansätze Frauen und deren Bedürfnisse zu stärken - „no official attempt was made to work with women in the budget forums" (Abers 2000: 128).

Demgemäß muss die Frage ob ein Partizipatives Budget Gender Budgeting ersetzen könnte folgendermaßen beantwortet werden: Das Partizipative Budget nach dem Vorbild Porto Alegres ist zwar nützlich, aber nicht ausreichend, wenn eine geschlechtergerechte und emanzipatorische Demokratisierung von Wirtschaftspolitik angestrebt wird. Denn es ist geschlechterblind und kann dementsprechend die Dynamiken der zentralen, vorherrschenden politischen Exklusion weder verstehen noch verändern: „By failing to include a gender perspective, participatory budgets run the risk of giving an illusion of plurality and inclusion, while actually fostering exclusion" (Vargas-Valente 2002: 105). Auch wenn das Partizipative Budget Elemente enthält, die potentiell zu Geschlechtergerechtigkeit beitragen könnten, ,,it is important to recognise that the context in which the PB operates, as well as the nature of PB itself, may also mitigate against this" (Lavan 2006: 7). So behält das Partizipative Budget die Geschlechterungerechtigkeiten, die auch den traditionellen Budgetprozess charakterisieren wie beispielsweise die Exklusion von Frauen aus Entscheidungspositionen oder die Ignoranz gegenüber unbezahlter, von Frauen geleisteter Arbeit, bei (vgl. VargasValente 2002: 111).

Hier setzen Gender Budget-Initiativen an, sie fokussieren auf eine Partizipation von Frauen im Budgetprozess und forden eine Einbeziehung der Geschlechterperspektive in die Finanz- und Wirtschaftspolitik: „In particular, a gender perspective forces policy makers to look at intra-household inequalities, to recognise women's unpaid work within the economy, and to address the way that discriminatory norms and values operate to exclude women both within and outside public institutions" (Norton/Elson 2002: 37). 
Die demokratischen Wirkungen von Gender Budgeting inkludieren das Potential einer demokratischen Debatte im Bereich der finanz- und wirtschaftspolitischen Prozesse aus einer Frauen- beziehungsweise Geschlechterperspektive ebenso wie eine Revision zu mehr (Geschlechter-) Gerechtigkeit. „This holds the possibility of closing the gaps between citizens, not only gender gaps, but also ethnic, class, and age gaps, as well as gaps because of geographical residence, between regions and peoples and between women themselves" (Vargas-Valente 2002: 105). Gender Budgeting impliziert auch eine Erweiterung der staatsbürgerlichen Rechte, wie "the right to accountability, transparency, oversight, consideration of one's opinions, and the possibility of influencing decision-making processes" (ebd.).

Dementsprechend bin ich der Auffassung, dass Gender Budget-Initiativen keinesfalls zugunsten eines Partizipativen Budgets aufgegeben oder zurückgewiesen werden dürfen, denn damit würden auch deren grundlegende feministische, geschlechtergerechte und emanzipatorische Ansprüche verloren gehen, die über die Ansprüche des PB hinausgehen. Daher argumentiere ich nicht für ein Entweder-Oder der Initiativen sondern vielmehr für ein gegenseitiges Lernen und Profitieren ${ }^{41}$ ebenso wie für die Herausforderung, einen substantiellen partizipativen Ansatz in Gender Budget-Initiativen einzubauen.

\subsubsection{Welche demokratietheoretischen Grundlagen braucht Gender Budgeting?}

Es ist nochmals festzuhalten, dass Gender Budgeting ein großes emanzipatorisches Potential zugeschrieben wird (vgl. Kapitel 2.3), mit dem Forderungen nach einer Demokratisierung der Finanz- und Wirtschaftspolitik verbunden sind (vgl. Kapitel 2.4 sowie 3.2): Denn „Verfahren in Richtung Transparenz und Partizipationsmöglichkeiten zu entwickeln, um den Budgeterstellungsprozess in Richtung höhere Verteilungsgerechtigkeit zu beeinflussen, ist ein zentraler Ansatzpunkt emanzipatorischer Politik“" (Schuberth 2006: 58). Neben diesem Verständnis von Gender Budgeting als Strategie zur emanzipatorischen und geschlechtergerechten Gestaltung der Finanzpolitik, besteht also auch ein breiter

41 Auch einige PB-Initiativen haben mittlerweile das Potential „of mainstreaming gender into participatory budgeting initiatives" (Hofbauer-Balmori 2003: 3) erkannt: So wurden beispielsweise in Villa el Salvador (Peru) im Jahr 2000 und in Recife (Brasilien) im Jahr 2001 jeweils Partizipative Budgets eingeführt, bei denen Gender eine der zentralen Diskussions- und Entscheidungskategorien für die Allokation von Ressourcen darstellt und ein Gender Assessment einen eigenen Teil des Budgetprozesses einnimmt. Anliegen war, den partizipativen Prozess so zu gestalten, dass eine Diskussion um die geschlechterspezifischen Effekte des Budgets ermöglicht wurde (vgl. Sugiyama 2003: $11 \mathrm{f}$ und HofbauerBalmori 2003: 36). Diese beiden Beispiele „constitute a clear attempt at bringing participatory budgeting and gender-responsive budgets together" (Hofbauer-Balmori 2003: 50). 
Konsens über ein mit Gender Budgeting verbundenes Anliegen die Finanz- und Wirtschaftspolitik zu demokratisieren, partizipativer und transparenter zu gestalten. Gender Budget-Initiativen sind also in einem Kontext eines umfassenden Demokratisierungsanspruchs zu verorten.

In der Praxis ist jedoch eine gewisse Diskrepanz zwischen dieser Demokratisierungsanforderung von Gender Budgeting per definitionem und der Praxis von Gender Budget-Initiativen festzustellen (vgl. Kapitel 3.2.2.1). Eine weitere Diskrepanz besteht in der wissenschaftlichen Auseinandersetzung um das Thema Gender Budgeting, in der die Forderung nach Demokratisierung der Finanzpolitik zwar häufig betont wird, wie Demokratie beziehungsweise Demokratisierung jedoch im diesem Zusammenhang präzisiert, definiert und theoretisch fundiert werden soll, stellt bislang einen weitgehend unbehandelten Bereich im wissenschaftlichen Diskurs dar. Diese fehlende theoretische Basis der Präzisierung und Fundierung eines Demokratieverständnisses für Gender Budgeting wirkt auf die Gestaltung der demokratischen Praxis von Gender Budget-Inititativen. Dieser Stand des Gender Budgeting- und Demokratisierungsdiskurses führt mich zu folgenden leitenden Fragen für die weitere Forschungsarbeit dieser Dissertation:

Wie könnte Gender Budgeting der Forderung nach einer geschlechtergerechten Demokratisierung von Finanz- und Wirtschaftspolitik gerecht werden oder anders: Welches Demokratiekonzept beziehungsweise welches Demokratieverständnis und welche demokratietheoretischen Grundlagen müssen Gender Budgeting zugrunde gelegt werden damit es ein emanzipatorisches finanz- und wirtschaftspolitisches Instrument sein kann?

Wie schon in Kapitel 3 herausgearbeitet, muss eine geschlechtergerechte und emanzipatorische Demokratisierung von Wirtschafts- und Finanzpolitik im Sinn von Gender Budgeting jedenfalls mindestens drei Bedeutungen haben: Die Demokratisierung muss sowohl an der Substanz, den Inhalten, als auch an den Institutionen und Prozessen von finanz- und wirtschaftspolitischen Entscheidungen ansetzen, um allen Bürgerinnen und Bürger gleichwertige Einfluss- und Mitbestimmungsmöglichkeiten an den Entscheidungsprozessen und Aktivitäten zu gewährleisten sowie gesellschaftliche und geschlechterspezifische Machtverhältnisse beziehungsweise Ressourcenverteilungen zu verändern.

In den folgenden Kapiteln werde ich demgemäß eine theoretische Fundierung und Präzisierung eines Demokratiekonzept und -verständnis für Gender Budgeting erarbeiten. Da die feministische Politikwissenschaft über eine lange und umfassende Auseinandersetzung mit demokratischen Modellen, deren Chancen und Problemen bezüglich der Partizipation von Frauen verfügt, ist das Ziel der folgenden Kapitel eine systematische Untersuchung der zentralen Begrifflichkeiten und Konzepte der feministisch demokratietheoretischen Debatte ebenso wie der Demokratietheorien ausgewählter feministischer Theoretikerinnen. 


\section{Demokratieverständnis und -konzept für Gender Bud- geting: Ein Kriterienkatalog feministischer Demokratie- theorien}

Eine Auseinandersetzung mit feministischen Demokratiekonzeptionen zeigt, dass es die eine feministische Großtheorie der Demokratie nicht gibt und „feministische Demokratietheorie noch erfunden werden muss" (Holland-Cunz 1998: 17). Daher möchte ich in diesem Kapitel mit Hilfe einer Qualitativen Inhaltsanalyse gemeinsame zentrale Inhalte, Dimensionen und Konzepte feministischer Demokratietheorien in den Arbeiten verschiedener Demokratietheoretikerinnen identifizieren. Das Ziel ist eine strukturierte Darstellung feministischer demokratietheoretischer Überlegungen um daraus einen Kriterienkatalog entwickeln zu können. Dieser resultierende Kriterienkatalog soll als ein Modell von demokratischen Prinzipien eine Analyse von Budgetprozessen hinsichtlich der Erfüllung von demokratischen und geschlechterdemokratischen Kriterien ermöglichen.

\subsection{Methodische Vorgangsweise: Eine Qualitative Inhaltsanalyse}

Eine Inhaltsanalyse ist grundsätzlich „eine Methode zur Erhebung sozialer Wirklichkeit, bei der von Merkmalen eines manifesten Textes auf Merkmale eines nichtmanifesten Kontextes geschlossen wird.“ (Merten 1983: 16). Mit Hilfe einer Qualitativen Inhaltsanalyse kann fixierte Kommunikation - beispielsweise Texte - systematisch, regelgleich und theoriegeleitet, mit dem Ziel, Rückschlüsse auf bestimmte Aspekte der Kommunikation ziehen zu können, analysiert werden (vgl. Mayring 2003: 13). Philipp Mayring hat zu Beginn der 1980er Jahre ein Verfahren der Qualitativen Inhaltsanalyse entwickelt, das den Anspruch erhebt „sich an der Komplexität von Informationen und am Verstehen“ orientieren zu können, ,aber den Vorzug der Inhaltsanalyse, theorie- und regelgeleitet vorzugehen, beibehalten kann" (Gläser/Laudel 2006: 192). Sein Ziel war eine Verfahrensweise systematischer Textanalyse zu entwickeln, die die „Stärken der kommunikationswissenschaftlichen Inhaltsanalyse nutzen [kann], um qualitative Analyseschritte methodisch kontrolliert vollziehen $\mathrm{zu}$ können" (Mayring 2000: 8). Hierbei stützte er sich auf die Hermeneutik, die Literaturwissenschaften und die Psychologie der Textverarbeitung. Grundsätzlich geht es bei seinem Verfahrensvorschlag um Konfigurationen und Typisierungen von Informationen in Texten (vgl. ebd.: 193). Die Qualitative Inhaltsanalyse in dieser Variante ist eine Auswertungsmethode - denn „sie hat es mit bereits fertigem sprachlichen Material zu tun" (Mayring 2003: 46) - der verschiedene spezielle Techniken zugrunde liegen. Ich werde für die folgende Arbeit die „wohl zentralste inhaltsanalytische Technik“ (Mayring 2003: 82), die Inhaltliche Struktu- 
rierung, anwenden. Mit deren Hilfe ist es im Zuge des in Abbildung 7 dargestellten allgemeinen Ablaufmodells möglich aus sprachlichem Material eine bestimmte Struktur herauszufiltern.

Abbildung 7: Allgemeines Ablaufmodell der Strukturierenden Inhaltsanalyse

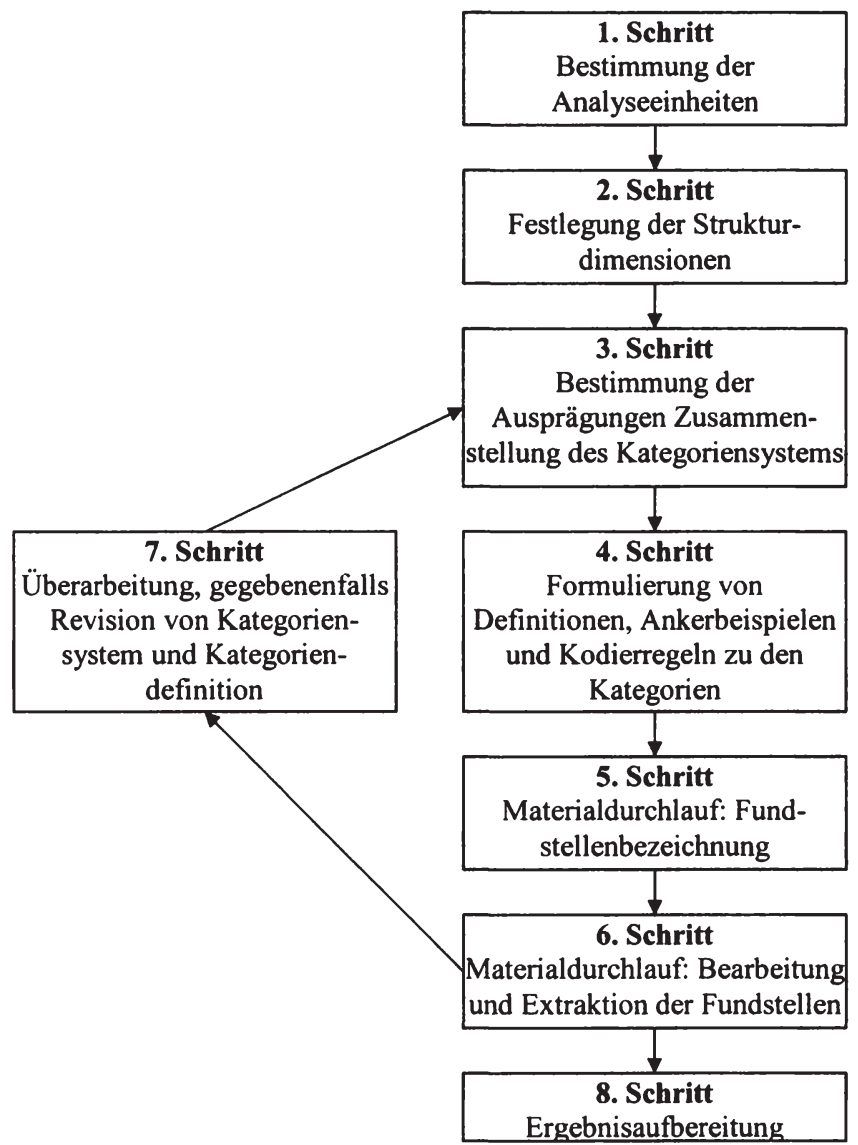

Quelle: Mayring 2003: 84, eigene Darstellung

Dieses allgemeine Ablaufmodell ist jedoch für meine Zwecke zu allgemein um damit konkret arbeiten zu können, daher verwende ich die spezifische Form der Strukturierenden Inhaltsanalyse mit inhaltlicher Vorgehensweise. Diese Inhaltliche Strukturierung zielt darauf ab, bestimmte Themen, Inhalte und Aspekte aus dem Material zu filtern, abzuwägen und neu zu strukturieren (vgl. Mayring 2003: 89). 
Abbildung 8: Ablaufmodell der Inhaltlichen Strukturierung

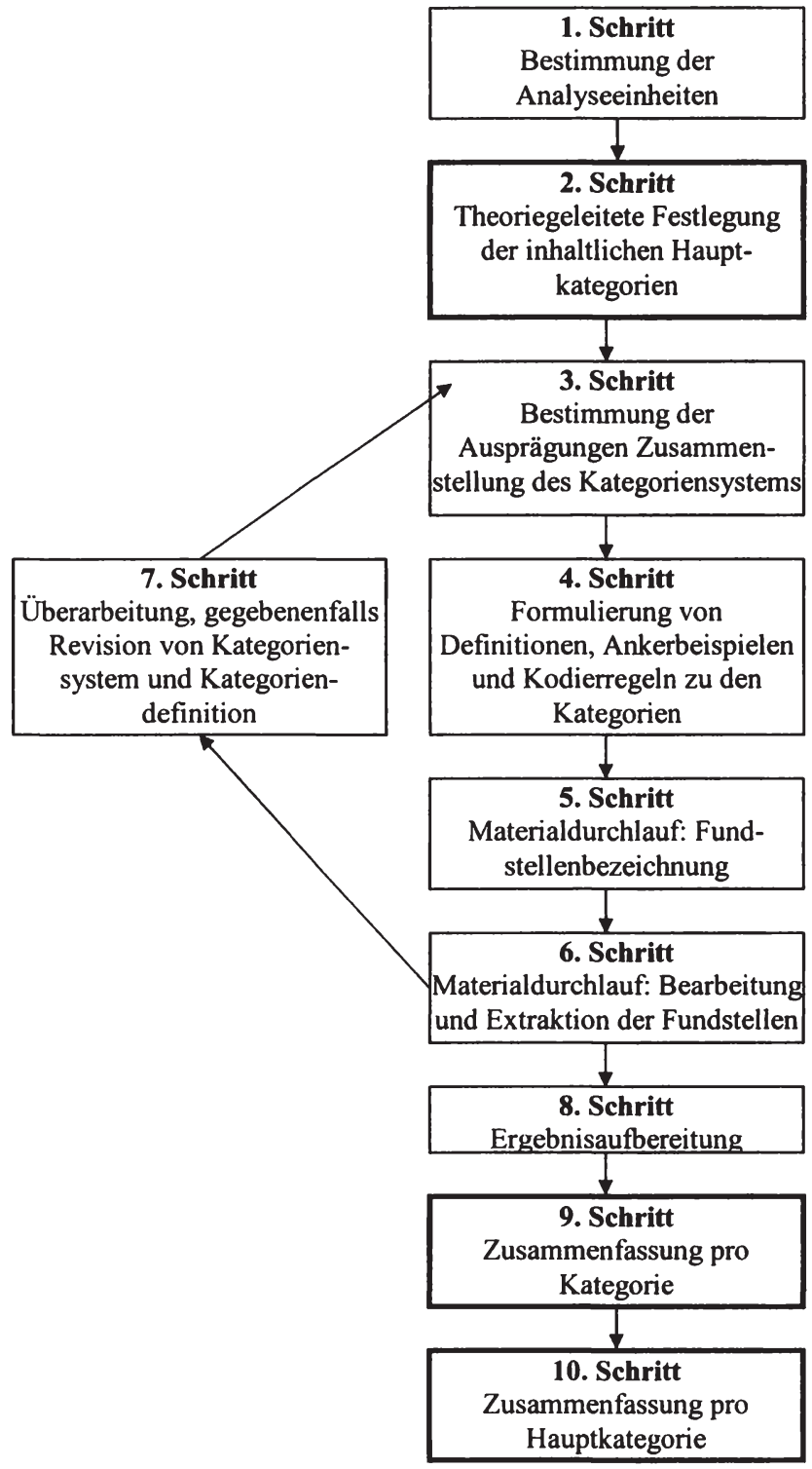

Quelle: Mayring 2003: 89, eigene Darstellung 
Mit ihrer Hilfe kann „Material zu bestimmten Themen, zu bestimmten Inhaltsbereichen" (Mayring 2003: 85) extrahiert und neu zusammengestellt werden. Abbildung 8 zeigt die schematische Vorgehensweise der Inhaltlichen Strukturierung, deren Ablauf sich vom allgemeinen Modell durch die Spezifizierung des 2. Schritts, in dem anhand theoriegeleitet entwickelter Kategorien definiert wird, welche Inhalte aus dem Material extrahiert werden sollen (vgl. Mayring 2003: 89), sowie durch die zusätzlichen Schritte 9 und 10, unterscheidet.

Für den ersten Schritt der Inhaltlichen Strukturierung, die Bestimmung der Ausgangssituation sind einige Vorarbeiten nötig: Zunächst ist das Ausgangsmaterial zu bestimmen, ,um zu entscheiden, was überhaupt aus dem Material herausinterpretierbar ist" (Mayring 2003: 46). Hierbei geht es um dreierlei, um die Festlegung des Materials, um die Entstehungsprozesse des Materials sowie deren formale Charakteristika.

Den „Corpus“ (Mayring 2003: 47) meiner Analyse bilden internationale feministische, demokratietheoretische Aufsätze. Das von mir ausgewählte Material entspricht drei inhaltlichen Kriterien: Erstens handelt es sich zunächst um Demokratietheorien, allen Arbeiten liegen Forschungsfragen rund um die Ausgestaltungen von Demokratie zugrunde. Zweitens liegt der Fokus dieser Demokratietheorien auf feministischen Untersuchungen, es geht im weitesten Sinne darum, patriarchale und androzentristische Willensbildungs-, Entscheidungsprozesse und Politikformen aufzudecken und diese so zu transformieren, dass beide Geschlechter in die Demokratietheorie eingeschrieben werden sowie auch um den Versuch institutionelle Lösungen und Vorschläge für das geschlechtsspezifische Demokratiedefizit moderner Demokratien darzulegen. Drittens habe ich mich auf diejenigen Arbeiten konzentriert, die außerdem (gesamtgesellschaftlich) emanzipatorische Ansprüche aufweisen, also zu einer Herausführung aus Unterdrückung und Unmündigkeit beitragen wollen.

Das meiner Arbeit zugrunde liegende Material kann des Weiteren anhand folgender formaler Kriterien charakterisiert werden: Es handelt sich hierbei um veröffentlichte ${ }^{42}$ Monographien sowie um Artikel und Aufsätze in Sammelbänden, Journals, um Konferenzdokumentationen und um Informationen aus dem Internet. Zum überwiegenden Teil setzt sich mein Material aus Arbeiten von Frauen zusammen, deren Entstehungszusammenhang ein internationaler ist. Wenngleich es sich bei dem Großteil der Arbeiten zu feministischen Demokratietheorien um europäische und amerikanische Ansätze handelt, habe ich jedoch

42 Ich zähle zu „veröffentlicht“ all jene Materialen, die öffentlich zugänglich sind. Daher handelt es sich bei den von mir untersuchten Texten nicht ausschließlich um verlegte Materialien, sondern auch um von AutorInnen als Konferenzunterlagen zur Verfügung gestellte Texte sowie von ihnen ins Internet gestellte Materialien. 
auch versucht zumindest einige Arbeiten von Frauen des Südens zu finden und einzubinden ${ }^{43}$.

Als Vorarbeit für die Bestimmung der Analyseeinheiten ist außerdem eine Bestimmung der Richtung der Analyse beziehungsweise die spezifische Fragestellung der Analyse notwendig. Qualitative Inhaltsanalysen zeichnen sich gerade durch zwei Merkmale aus, die Regelgeleitetheit und die Theoriegeleitetheit der Interpretation. Daher bedarf es einer präzisen, theoretisch begründeten inhaltlichen Fragestellung als Ausgangspunkt. Theoriegeleitetheit bedeutet in diesem Zusammenhang, dass die Fragestellung der Analyse theoretisch an die bisherige Forschung zum behandelten Gegenstand angebunden sein muss und davon ausgehend auf der Material hin einwickelt wird (vgl. Mayring 2003: 52ff).

Wie bereits in Kapitel 3.2.4 dargelegt, habe ich für die vorliegende Dissertation folgende Forschungsfrage anhand des Forschungstandes zu Gender Budgeting entwickelt: Welche demokratietheoretischen Grundlagen und welches Demokratiekonzept beziehungsweise Demokratieverständnis braucht Gender Budgeting um ein emanzipatorisches finanz- und wirtschaftspolitisches Instrument sein $\mathrm{zu}$ können?

Anhand dieser Forschungsfrage nehme ich in einem nächsten Schritt die, für die Inhaltliche Strukturierung notwendige, theoriegeleitete Festlegung der Hauptkategorien vor. Die Bildung eines Kategoriensystems ist ein zentraler Punkt der Qualitativen Inhaltsanalyse und ein ,sehr sensibler Prozess, eine Kunst“ (Mayring 2003: 74) über den in inhaltsanalytischen Standardwerken relativ wenig geschrieben wurde: „How categories are defined (...) is an art. Little is written about it" (Krippendorff 1980: 76 zit. in Mayring 2003: 43). Auch die „Zuordnung der Kategorien zu den Textstellen geschieht nicht automatisch, sondern stellt einen Interpretationsakt dar“, der jedoch so „regelgeleitet und so explizit wie möglich sein" (Mayring 2005: 11) soll.

$\mathrm{Da}$ es in der vorliegenden Arbeit darum geht festgelegte, theoretische Auswertungsaspekte an das Material heranzutragen um deren Inhalte neu zu strukturieren und in einen neuen Zusammenhang zu bringen, wende ich zur Kategorienbildung eine deduktive Vorgehensweise an. Im Zuge dieser deduktiven Kategoriendefinition werden die Kategorien aus dem bisherigen Forschungsstand, aus Voruntersuchungen beziehungsweise aus neu entwickelten Theorien in einem Operationalisierungsprozess auf das Material hin entwickelt (vgl. Mayring 2003:

43 Der internationale Entstehungszusammenhang der feministischen Demokratietheorien und die Einbeziehung von Arbeiten von Frauen aus dem Süden ist mir besonders wichtig, da in vielen Ländern des Südens mittlerweile ein lange und substantielle Tradition von Gender Budgeting-Initiativen besteht und deren Zahl stetig weiter steigt (vgl. u.a. Budlender et al 2002, Budlender/ Hewitt 2002 und Kapitel 3.2.1). Dementsprechend soll der zu erarbeitende Kriterienkatalog auch für die Kontexte des Südens adaptierbar sein. 
74f). Mittels eines theoretisch entwickelten Kategoriensets wird festgelegt wann ein Materialbestandteil unter eine Kategorie fällt, wobei hierfür ein dreistufiges Verfahren angewandt werden kann (vgl. Mayring 2003: 82):

- Definition der Kategorien: es ist genau zu definieren, welche Textbestandteile unter eine Kategorie fallen

- Ankerbeispiele: es werden beispielhafte Textstellen angeführt, die unter eine Kategorie fallen

- Kodierregeln: dort wo Abgrenzungsprobleme zwischen Kategorien entstehen können, werden Regeln formuliert um eindeutige Zuordnungen zu gewährleisten

In Kapitel 3 habe ich bereits herausgearbeitet, dass laut aktuellem Forschungsstand für eine Demokratisierung der Wirtschaftspolitik drei Dimensionen beachtet werden müssen: Der politisch-demokratischen Input ist für jede Demokratisierung der Demokratie absolut unverzichtbar (vgl. Holland-Cunz 1999: 87), ebenso wie das institutionelle Setting wirtschaftspolitischer Willensbildungs- und Entscheidungsprozesse und das Einfließen von Gerechtigkeitsüberlegungen in die Inhalte von Finanz- und Wirtschaftspolitik. Eine Demokratisierung von Finanz- und Wirtschaftspolitik muss sowohl an der Substanz als auch an den Institutionen und Prozessen von wirtschaftspolitischen Entscheidungen ansetzen, um eine möglichst optimale Beteiligung von Bürgerinnen und Bürgern an den wirtschaftspolitischen Entscheidungsprozessen und Aktivitäten zu gewährleisten und gesellschaftliche sowie geschlechterspezifische Machtverhältnisse und Ressourcenverteilungen zu verändern.

Dementsprechend habe ich als drei Hauptkategorien „Input“, „Institutionen und Prozesse“, sowie „Output" festgelegt und folgendermaßen definiert (vgl. Tabelle 2): Unter die Kategorie „Input“ fallen all jene Materialbestandteile, die den politischen Input, die Vorgänge und die Wertigkeit der Willensbildung und Entscheidungsfindung sowie deren Probleme beleuchten. Zur Kategorie „Institutionen und Prozesse" zählen diejenigen Textteile, die sich mit der Ausgestaltung von demokratisch-institutionellen Arrangements und Rahmenbedingungen beschäftigen, aufgrund derer politischer Input erst möglich wird. „Output" bezeichnet die Materialteile, die sich mit der Qualität des Regierens und der politischen Steuerung auseinandersetzen.

Feministische Demokratietheorien orientieren sich zwar überwiegend am politisch-demokratischen Input, daher ordnet beispielsweise Manfred Schmidt (2000: 252) die feministisch demokratietheoretische Ansätze am ehesten den partizipativen Demokratietheorien zu. Jedoch zielen feministische Demokratietheorien nicht nur auf den partizipativen Aspekt ab, sondern verknüpfen diesen mittlerweile auch mit dem institutionellen Setting politischer Willensbildungsund Entscheidungsprozesse sowie dem Output politischer Organe und Prozesse. 
Tabelle 2: Kodierleitfaden

\begin{tabular}{|l|l|l|l|}
\hline Kategorie & Definition & Ankerbeispiel & Kodierregeln \\
\hline K1: Input & $\begin{array}{l}\text { Politischer Input, Vor- } \\
\text { gänge und Wertigkeit } \\
\text { politischer Willens- } \\
\text { bildung und Entschei- } \\
\text { dungsfindung }\end{array}$ & $\begin{array}{l}\text { Partizipation von } \\
\text { Frauen }\end{array}$ & $\begin{array}{l}\text { Alle Veränderungen hinsicht- } \\
\text { lich einer Verbesserung der } \\
\text { Einbindung von Frauen in } \\
\text { politische Entscheidungen }\end{array}$ \\
\hline $\begin{array}{l}\text { K2: } \\
\text { Institutionen } \\
\text { und Prozesse }\end{array}$ & $\begin{array}{l}\text { Institutionen, Ar- } \\
\text { rangements und Rah- } \\
\text { menbedingungen } \\
\text { politischer Willensbil- } \\
\text { dungs- und Entschei- }\end{array}$ & $\begin{array}{l}\text { Responsivität poli- } \\
\text { tischer Institutionen }\end{array}$ & $\begin{array}{l}\text { zessen, Institutionen ebenso wie } \\
\text { innerhalb von Institutionen um } \\
\text { deren Responsivität gegenüber } \\
\text { den Belangen von Frauen zu } \\
\text { erhöhen }\end{array}$ \\
\hline K3: Output & $\begin{array}{l}\text { Output, Leistungs- } \\
\text { fähigkeit politischer } \\
\text { Prozesse und Organe }\end{array}$ & $\begin{array}{l}\text { Frauenfreundlicher } \\
\text { Output von Poli- } \\
\text { tiken }\end{array}$ & $\begin{array}{l}\text { Alle Veränderungen hin zu } \\
\text { geschlechtergerechten und } \\
\text { frauenfreundlichen Politiken, } \\
\text { die Frauen empowern und sie } \\
\text { von Unterdrückung und Herr- } \\
\text { schaft befreien }\end{array}$ \\
\hline
\end{tabular}

Quelle: eigene Darstellung

Die inhaltlichen Ansätze, die zentralen Kriterien und Konzepte der verschiedenen Demokratietheoretikerinnen werde ich im Folgenden anhand der drei Kategorien K1-K3 herausarbeiten. Diese Kriterien sollen mir im Weiteren als Ansatz für einen Kriterienkatalog beziehungsweise zur Erarbeitung eines Demokratiemodells für Gender Budgeting dienen und werden in den folgenden Kapiteln näher ausgeführt.

$\mathrm{Zu}$ beachten ist hierbei jedenfalls, dass sich bis dato die meisten Arbeiten und Ansätze feministischer Demokratietheoretikerinnen im Bereich der Kategorien K1 Input und K2 Institutionen und Prozesse finden.

\subsection{Input (K1)}

\subsubsection{Anerkennung von Geschlechterdifferenz}

Der Ausgangspunkt feministischer Demokratietheorie ist die Frage, wie die Geschlechterdifferenz, also die sozial hergestellte Unterschiedlichkeit von Erfahrungen, Identitäten und Interessen, politisch sichtbar und repräsentierbar gema- 
cht werden kann, ohne dass der Anspruch der politisch-demokratischen Gleichheit preisgegeben wird. Politische Differenz meint in Demokratietheorien keine Zuschreibung, sondern bildet ein Erkenntnisinstrument (vgl. Sauer 2003a: 9), um den männlichen Partikularismus vermeintlicher Universalität sichtbar zu machen, denn "what appears neutral is actually androcentric or male-defined" (Squires 1999: 119). Die Vorstellung von abstrakten Individuen fördert das Bild eines Individuums und Bürgers als geschlechtlich neutrales Wesen. In Gesellschaften aber, die entlang der Kategorie Geschlecht strukturiert sind, verstärkt eine solche Indifferenz gegenüber dem Geschlecht nur die Position von Männern und führt zu einer politischen Unterrepräsentation und Benachteiligung von Frauen (vgl. Phillips 1993: 115). Der abstrakte Individualismus impliziert eine einheitliche Vorstellung von menschlichen Bedürfnissen und Anliegen und dient damit einer Marginalisierung all jener Gruppen, die von der dominanten Norm männlicher Lebens- und Arbeitsrealität abweichen. So erscheinen die Bedürfnisse von Frauen als Spezialfälle und ethnische Unterschiede werden unter „Probleme ethnischer Minderheiten“ subsumiert. Die Dominanz der Norm ist so mächtig, dass verborgen bleibt, dass sich die meisten Menschen außerhalb dieser Grenzen bewegen (vgl. ebd.: 95).

Daher kann die Demokratie nicht „über die Geschlechterdifferenz erhaben sein, vielmehr muss sie mit einem deutlichen Bewusstsein dieser Differenz neu bestimmt werden. Eine offensichtliche Konsequenz ist, dass die Demokratie uns nicht mehr nur als Individuen, sondern auch als Gruppen behandeln muss (...). Jedes Argument für eine verstärkte Frauenrepräsentation in der Politik gründet auf einem solchen Standpunkt. Die Zusammensetzung unserer gewählten Versammlungen ist deshalb von Bedeutung, weil die Menschen nicht alle gleich sind" (Phillips 1995: 240).

Mit der Idee der Differenz begeben sich feministische Demokratietheoretikerinnen allerdings auf ein schwieriges Terrain, da die Gefahr besteht, dass an die Stelle eines ,universell verbrämten männlichen Partikularismus ein Partikularismus mit weiblichem Angesicht tritt“ (Sauer 2003a: 9). Eine weitere Schwierigkeit des Differenzdenkens besteht in der Frage, wie der Geschlechterunterschied repräsentiert werden soll, ohne dass jedoch das Resultat eine biologistische $\mathrm{Zu}$ schreibung von weiblichen Wesensmerkmalen wie beispielsweise ,weibliche Politik“ oder essentialistische Gruppenvorstellungen (wie „die“ Frauen) ist.

„Die feministische Thematisierung von Differenz sollte daher vornehmlich als heuristisches Moment begriffen werden. Die institutionelle Umsetzung einer politischen Geschlechterdifferenz muss sich des Spannungsverhältnisses zum Gleichheitsanspruch sowie der Gefahr der essenzialisierenden Festschreibung stets bewusst sein. Nur so kann der maskulinistischen Geschlechterindifferenz begegnet werden" (Sauer 2003a: 9f). 
Der Differenzgedanke verknüpft politische mit sozialer Gleichheit: Nur wenn Frauen den Männern nicht gleich gemacht werden, ist die Voraussetzung auch für politische Gleichheit von Männern und Frauen gegeben, denn es existieren zwei verschiedene Arten von Hindernissen für eine demokratische Partizipation: „Eines dieser Hindernisse ist die soziale Ungleichheit, ein anderes die Missachtung von Differenz" (Fraser 2001: 251). Demokratie erfordert heute sowohl eine ökonomische Umverteilung als auch eine multikulturelle Anerkennung und muss „eine kulturbetonte Politik der Anerkennung mit einer Sozialpolitik der Umverteilung" (ebd.: 263f) verbinden, denn falls sie dies nicht schafft wird sie „nicht wirklich demokratisch sein“, da sie keine „demokratische Vermittlung zwischen vielfältigen, sich überschneidenden Differenzen" (ebd.: 264) zustande bringen könnte. Kulturelle Differenzen können ,nur auf der Grundlage sozialer Gleichheit frei entfaltet und demokratisch vermittelt werden“ (ebd.: 265). „Social equality (...) refers primarily to the full participation and inclusion of everyone in a society's major institution, and the socially supporter substantive opportunity for all to develop and exercise their capacities and realize their choices" (Young 1990: 173).

Analytisch kann Ungerechtigkeit als ein kulturelles oder symbolisches Phänomen aufgefasst werden, deren Ursachen ,in sozialen Mustern der Anerkennung, Interpretation und Kommunikation" (Fraser 2001: 28) liegen. Beispiele dafür sind kulturelle Dominanz, fehlende Anerkennung und Missachtung. Maßnahmen gegen kulturelle Ungerechtigkeiten müssen bei gesellschaftlichen Normen ansetzen und auf einen kulturellen oder symbolischen Wandel abzielen. „Dieser Wandel kann die Aufwertung missachteter Identitäten und kultureller Hervorbringung verächtlich gemachter Gruppen beinhalten. Er kann auch die Anerkennung und positive Wertschätzung kultureller Vielfalt umfassen. Noch radikaler gesehen, kann damit die Umgestaltung gesellschaftlicher Muster der Darstellung, Interpretation und Kommunikation im Ganzen gemeint sein, und zwar auf eine Art und Weise, die das Selbstverständnis eines jeden verändern würde" (ebd.: 30f). Oberbegriff hierfür ist der der „Anerkennung“. So ist Gender als soziales Geschlecht nicht nur eine politisch-ökonomische, sondern auch eine kulturell-evaluative Differenzierung. Als eine solche umfasst Gender Elemente, „die mehr dem Idealtypus verachteter Sexualität gleichen und die Gender mit der Anerkennungsproblematik in Übereinstimmung bringen. Ein Grundzug der genderbezogenen Ungerechtigkeit ist sicherlich der Androzentrismus: eine autoritative Konstruktion von Normen, die mit Männlichkeit assoziierte Merkmale privilegiert" (ebd.: 41). Dies wird von einem kulturellen Sexismus begleitet, von einer weit verbreiteten Herabsetzung und Abwertung von allem das feminin codiert ist. Solche Abwertungen drücken sich in einer ganzen Reihe von diskriminierenden Handlungen gegenüber Frauen aus. Hierzu zählen sexuelle Übergriffe, sexuelle Ausbeutung und häusliche Gewalt ebenso wie trivialisierende, zum Objekt herabsetzende und/oder lächerlich machende, stereotype Darstel- 
lung in den Medien. Auch die Unterwerfung und Messung an androzentrische Normen, anhand derer Frauen als unfähiger oder abweichend erscheinen und die sich ihnen gegenüber auch dann als Nachteil erweisen, wenn keine explizite Diskriminierung beabsichtigt wird, sind Ausdruck dieser Abwertungen. Änderungen dieser Unrechtverhältnisse lassen sich durch politisch-ökonomische Umverteilung alleine nicht erreichen, sondern bedürfen zusätzlicher Maßnahmen, die zu mehr Anerkennung verhelfen. $\mathrm{Zu}$ einer Überwindung von Androzentrismus und Sexismus müssen kulturelle Wertungen sowie ihr rechtlicher und praktischer Ausdruck geändert werden, die Männlichkeit privilegieren und Frauen gleiche Achtung vorenthalten. Gender ist also ein zweiwertiger Modus, denn es beinhaltet eine politisch-ökonomische Seite, die in den Zuständigkeitsbereich der Umverteilung fällt ebenso wie auch eine kulturell-evaluative Seite, die dem Bereich der Anerkennung zugeordnet werden kann. Beide Seiten sind nicht exakt voneinander trennbar, sondern vielmehr ineinander verschlungen, so dass sie sich in dialektischer Weise verstärken.

„Denn sexistische und androzentrische kulturelle Normen sind im Staat und in der Wirtschaft institutionalisiert, und die ökonomische Benachteiligung von Frauen lässt die "Stimme « der Frauen nur stellenweise durchdringen, da sie eine gleiche Beteiligung an der Kulturproduktion in öffentlichen Bereichen und im Alltagsleben verhindert. Das Ergebnis ist eine kulturelle und wirtschaftliche Unterordnung. Eine Beseitigung gendertypischer Ungerechtigkeit verlangt deshalb, dass beide, politische Ökonomie und Kultur verändert werden“ (Fraser 2001: 42).

\subsubsection{Partizipation von Frauen}

„Politische Partizipation ist ein zentraler Aspekt, gewissermaßen die Handlungsseite von Demokratie. Sie gilt als der elementare Bestandteil der (politischen) Selbstverwirklichung des Menschen" (Sauer 2001: 201). Politische Partizipationsansprüche und -rechte ,sind nach wie vor entlang einer Geschlechterlinie verteilt" (ebd.: 204). Das konventionelle Partizipationsverhalten von Frauen und Männern hat sich zwar seit den 1980er Jahren sukzessive angepasst, so dass heute von einem grundsätzlichen Gender Gap in der Häufigkeit politischer Teilnahme kaum mehr die Rede sein kann. Längst können Frauen nicht mehr als die „schlechteren Demokratinnen“ bezeichnet werden (vgl. Sauer 2003a: 11).

Diese Reduktion der geschlechtsspezifischen Partizipationsunterschiede wird in der Regel mit der ökonomischen Entwicklung und der wachsenden Bildungsund Erwerbsbeteiligung von Frauen erklärt. „Dementsprechend ging man lange Zeit von einem stetigen Angleichungsprozess des Partizipationsverhaltens von Frauen an das von Männern aus. Das ,Frauenproblem' schien erledigt, und es galt als eine Frage der Zeit, bis Frauen vollends zu ,politischen Männern' ge- 
worden seien. Geflissentlich übersehen wurde dabei die hartnäckige und dauerhafte Unterrepräsentanz von Frauen im politischen System“"(Sauer 2001: 207).

Geschlechtsspezifische Unterschiede blieben also bestehen und wir haben es mittlerweile „mit einer spezifischen Struktur der Geschlechtersegregation in der Politik" (Sauer 2001: 212) zu tun, beispielsweise in der Form politischer Partizipation: Während sich Männer stärker an öffentlichen politischen Diskussionen und in der Parteipolitik beteiligen, sind in der Gruppe der so genannten jüngeren Initiativen (bis 42 Jahren), die in BürgerInnenbewegungen aktiv sind, Frauen gleich, wenn nicht sogar überrepräsentiert. Dies führt zu einer These, dass Frauen möglicherweise ein anderes Verständnis von Politik besitzen (vgl. Sauer 2003a: 11). Außerdem existieren nach wie vor signifikante Unterschiede der Geschlechter im Politikinteresse, wobei Frauen ein deutlich geringeres Interesse an der Politik äußern. Die feministische Politikwissenschaft fragt deshalb, ob politische Partizipation von Frauen ein Problem ist oder ob Frauen mit der vorherrschenden Ausformung politischer Partizipation ein Problem haben (vgl. ebd.).

Die feministische Demokratiekritik setzt in der Folge primär an den fehlenden partizipativen Möglichkeiten für Frauen an, denn „Partizipation ist in repräsentativen Demokratien auf turnusmäßig verknappte Momente der Wahl politischer RepräsentantInnen reduziert" (ebd.). Dieser Modus der Wahl jedoch ermöglicht keine angemessene Repräsentation von Frauen in politischen Entscheidungspositionen und ist keineswegs eine Garantie dafür, dass von den gewählten Repräsentantinnen und Repräsentanten Frauenthemen auf die politische Agenda gesetzt werden. Das vermeintlich mangelnde Interesse von Frauen an der Politik „entpuppt sich damit als Effekt des ,Männerberufs' Politik“ (ebd.).

Die modernen westlichen Demokratien setzen zwar auf Sanktionen durch Wahlen, versagen aber gleichzeitig in der Beschäftigung mit den Unzulänglichkeiten des Wählens als Ausdruck von Interessen und Bedürfnisse der Bürgerinnen und Bürger. Demokratietheoretische WissenschafterInnen argumentieren schon lange, dass Wahlen alle fünf Jahre kaum als substantieller Ausdruck von Kontrolle durch die Bürgerinnen und Bürger gesehen werden können und dass ein Auswählen zwischen Alternativen, die sich möglicherweise nur aufgrund von Details voneinander unterscheiden, zumeist vage formuliert und viel zu oft wieder aufgegeben wurden, Bürgerinnen und Bürgern kaum eine Wahl lässt und somit tatsächliche Entscheidungen politischen Eliten überlassen bleiben (vgl. Phillips 1993: 112).

Das feministische Partizipationsverständnis hat zwei Bezugspunkte: zum einen die Steigerung der Partizipationschancen von Frauen innerhalb von repräsentativen Institutionen und zum anderen ein basis- beziehungsweise versammlungsdemokratische Ideal der Frauenbewegung jenseits von etablierten Politikstrukturen (vgl. Sauer 2003a: 11): „The first aims to increase women's participation within formal institutional politics, the second to extend the definition of the 
political in such a way as to reveal and valorize women's extensive political participation outside the formal institutions" (Squires 1999: 195). Feministische Demokratietheorien fordern daher neben formal-rechtlichen Partizipationschancen wie Quoten auch eine strukturelle Ermöglichung von Partizipation wie beispielsweise bessere Bildungs- und Aufstiegsoptionen, aber auch die Verfügung über materielle Ressourcen, denn „StaatsbürgerInnenschaft ist auch eine Frage der Bereitstellung ökonomischer, sozialer und kultureller Chancen" (Sauer 2001: 233). Mit einem frauenbewegten Politik-Ideal ist außerdem ein normativer, nicht-instrumenteller Partizipationsbegriff verbunden: „Partizipation wird im Gegensatz zur rituellen Vergewisserung staatlich-administrativer Institutionen in Wahlen und im Unterschied zur bloß interessenorientierten Beeinflussung der politischen Entscheidungsträger als Teilnahme am politischen Gemeinwesen mit dem Ziel einer gerechteren Gesellschaft konzipiert" (Sauer 2003a: 11). Partizipation soll als Kern einer BürgerInnenschaftlichkeit ein gemeinsamer, kommunaler und interaktiver Lernprozess sein. Die aktive Schaffung von Zeiten und Orten für politische Beteiligung wäre damit eine unbedingt notwendige Voraussetzung für die Staatsbürgerin ebenso wie auch für den Staatsbürger (vgl. ebd.): ,In other words, rather than pitting informal, participatory democratic practices against formal, institutional structures, they should be seen as requiring the latter (...) The apparent dichotomy between formal and informal political activity, between representative and participatory conceptions of the political, is displaced in favour of a reconsideration of the inter-relation between the two" (Squires 1999: 200).

Demgemäß beharren feministische Demokratietheorien auf einem expansiven Verständnis politischer Partizipation und auf der Kernvorstellung der partizipatorischen Strömung von „Demokratie als Lebensform" (Holland-Cunz 1999: 217). „Demokratische Partizipation wird als patriarchal vorenthaltene soziale Verpflichtung verstanden, für deren Realisierung in allen Lebensbereichen, insbesondere auch in der Privatheit, politisch gekämpft werden muss" (HollandCunz 1998: 107). Wichtig wäre hierbei eine „thematische Expansion mit streng definierten Diskursformen", eine Expansion politischer Räume würde mit einer genauen Bezeichnung der Strukturen des expandierten Poltischen verbunden werden und für alle transparent gemacht werden (vgl. ebd.: 186).

Eine Schlüsselbedeutung im Zusammenhang mit Demokratie hat daher die transformative Wichtigkeit und Wirkung von Treffen, Gesprächen und Diskussionen. Denn Interessen sind nicht einfach da, vorgegeben oder fixiert. In einer Demokratie sollte es nicht nur um das (gelegentliche) Registrieren von existierenden Präferenzen und Ansichten gehen. Vielmehr muss der vorhergehende kontinuierliche Prozess der Kreation einer eigenen Identität ebenso wie der Konstruktion eigener Interessen und das Formen eigener politischer Ansichten in den Mittelpunkt gerückt werden. Die Unzulänglichkeiten von Wahlen bestehen 
also nicht nur darin, dass sie in großen Zeitabständen stattfinden und dass sie keine substantielle Kontrollmöglichkeit für die Bürgerinnen und Bürger schaffen, sondern auch in der Annahme exogener Interessen, die gerade vor dem Hintergrund einer sozialen Konstruktion von Weiblichkeit (und implizit auch von Männlichkeit) nicht stichhaltig ist. Denn gerade Gender strukturiert unser Selbstverständnis, unsere Bedürfnisse und unsere Interessen. Anne Phillips plädiert daher für eine aktivere Demokratie und gleichzeitig für eine feministische Analyse von Unterdrückung, die über die materiellen Ungleichheiten von Einkommen und Beschäftigung hinausgeht und die Marginalität von Frauen und den Mangel an Macht von Frauen in den Fokus nimmt. Wenn geschlechterspezifische Ungleichheiten auf die Verteilung von Einkommen und Arbeit (zu wenig des ersten und viel zu viel des zweiten) reduziert wird, könnten diese Ungleichheiten von oben "geheilt" werden. Denn Frauen könnten - bewaffnet mit der entscheidenden demokratischen Waffe, Wahl - eine Regierung wählen, die auf Frauenarmut reagieren würde und sich Programmen wie gleicher Lohn für gleiche Arbeit und wohlfahrtsstaatlichen Politiken, die frauenspezifische Bedürfnisse befriedigen verpflichten würde. Die Probleme von Unterdrückung können aber durch Umverteilung alleine nicht gelöst werden, denn diese bezieht sich nur auf den ungleichen Endzustand in der Verteilung, sondern benötigen einen institutionellen Kontext, in dem Partizipation und die Entwicklung eigener Kapazitäten möglich sind, in dem vor allem eine aktive Einbindung von Frauen möglich ist, damit diese Entscheidungen für sie selbst treffen können. Das Problem der repräsentativen Demokratie jedoch liegt nicht so sehr in ihrer vermeintlichen Unfähigkeit erweiterte Partizipation zu gestalten, sondern vielmehr in ihrer Selbstgefälligkeit, mit der sie angibt, allen legitimen demokratischen $\mathrm{Be}-$ strebungen gerecht zu werden (vgl. Phillips 1993: 113f).

Zusammenfassend kann also festgehalten werden: Die Frage der Partizipation von Frauen darf die feministische Erkenntnis, dass „der Staat und seine Institutionen „gendered“ sind und dass Politik ein männliches Deutungs- bzw. Konstruktionsmonopol besitzt" nicht außer Acht lassen, denn die politische Partizipation scheitert letztlich auch an der „Privatisierung von Frauen und der Entöffentlichung der ihnen zugeschriebene gesellschaftlichen Sphäre" (Sauer 2001: 231).

Die geringe Partizipationsbereitschaft von Frauen liegt ebenso in den „strukturellen Exklusionsverfahren des politisch-parlamentarischen Systems" (ebd.) und in den fehlenden Partizipationsmöglichkeiten der repräsentativen Demokratien begründet. Demgemäß müssen alle Ebenen der Partizipationsbedingungen ,systematisch um den Geschlechteraspekt erweitert werden. Zentral für die Konzeptionalisierung des Geschlechtersystems als Herrschaftssystem sind auch die Bedingungen der ökonomischen Struktur, die geschlechtsspezifische Arbeitsteilung 
also, und die institutionalisierten kulturellen Geschlechtermuster" (Sauer 2001: 232, vgl. auch Kapitel 4.2.1 und 4.4.1).

\subsubsection{Aktive Staatsbürgerinnenschaft von Frauen}

Citizenship, „der treffendere englische Begriff für den staatsbezogenen StaatsbürgerInnenschafts-Begriff, bezeichnet zunächst den Status politischer Mitgliedschaft in einem Gemeinwesen sowie die daraus ableitbaren Rechte und Chancen, dieses Recht aktiv in Anspruch zu nehmen" (Sauer 2003a: 10). Diese Rechte kategorisierte T.H. Marshall - ,whose work influenced thinking on citizenship in many European countries" (Lister/Hobson 2001: 4) - in folgende drei Gruppen: ,civil (liberty of the person, freedom of thought and faith and the right to justice); political (the right to participate in the exercise of political power); and social (the right to economic welfare and security, the right to live the life of a civilized being according to the standards prevailing in the society)" (Marshall 1950: $10 \mathrm{f}$ zit. in Squires 1999: 167). Diese dreiteilige Formulierung ist der Ausgangspunkt fast aller Diskussionen zur StaatsbürgerInnenschaft - „we are living in what might be termed a post-Marshallian age" (Lister/Hobson 2001: 1). Des Weiteren definierte Marshall Citizenship als ,a status bestowed on those who are full members of a community. All who possess the status are equal with respect to the rights and duties with which the status is endowed" (Marshall 1950: 28f zit. in Lister 1997: 1). Die Schlüsselelemente hierbei sind die Zugehörigkeit zu einer Gemeinschaft und die Rechte und Verpflichtungen die aus dieser Zugehörigkeit entspringen. Dies beschreibt jedenfalls nicht nur die legalen Regeln die das Verhältnis zwischen Individuen und dem Staat, in dem diese leben, regeln, sondern auch das ,set of sociological relationships between individuals and the state and between individual citizens" (Lister 1997: 1f).

Das Staatsbürgerkonzept hat seine Ursprünge in den zwei verschiedenen politischen Traditionen des Liberalismus und des bürgerlichen Republikanismus. Der Liberalismus versteht Citizenship als einen Status, der primär Rechte beinhaltet, die Individuen gewährt werden und Freiheit sowie formale Gleichheit der Individuen garantieren. Der bürgerliche Republikanismus hingegen sieht Citizenship als ein politisches Ideal und als eine Praktik, die Verantwortung innerhalb der Gesellschaft impliziert. In dieser Tradition wird die politische Partizipation als eine Pflicht verstanden und als ,the highest calling through which the citizen's full potential as a political being is realised. The emphasis is on the political obligations due to the citizenship community" (Lister/Hobson 2001: 3). Beide Traditionen zeichnen sich jedoch durch eine langjährige Ausschließung von Frauen sowohl in Theorie als auch Praxis der Staatsbürgerschaft aus und entstanden urtypisch als männliches Ideal. Die ausschließenden Tendenzen des Konzepts waren „far from accidental” (Lister 1997: 15) und „no aberration but (...) constitutive of the very idea of the citizen"(Lister/Hobson 2001: 5). Eine 
volle Staatsbürgerinnenschaft wurde Frauen in der Moderne lange verwehrt. Dieses Monopol der Männer und die noch immer währende geschlechtsspezifische Unterscheidung und Zuordnung zur öffentlichen beziehungsweise privaten Sphäre bedeutete, dass der Zutritt für Frauen zu männlichen Konditionen erfolgte (vgl. ebd.: 7).

Trotz formal gleicher politischer Rechte besitzen Frauen auch heute nur einen marginalisierten staatsbürgerlichen Status: Sie können ihre politischen Rechte wie beispielsweise das aktive und passive Wahlrecht, politische Interessensformulierung und -bündelung sowie Teilnahme am politischen Entscheidungsprozess - nicht in gleichem Maße wie Männer realisieren. Dafür gibt es mehrere Ursachen: Erstens wirken die Zuständigkeit für Reproduktionsarbeiten und das dadurch reduzierte Zeitbudget als mächtige Barrieren politischen Engagements: „Das Geschlecht ist und bleibt ein signifikanter (...) Indikator dafür, wo und in welchem Ausmaß wir politisch beteiligt sind. Dabei spielen die Konventionen, die den Frauen die primäre Verantwortung im häuslichen Bereich zuschreiben eine wesentliche Rolle“ (Phillips 1995: 162). Gerade die vielfältigen Betreuungspflichten von Frauen für Kinder, Kranke und Alte ebenso wie für leistungsfähige Männer erschweren Frauen den Zugang zur Politik (vgl. Phillips 1993: 106). Social Citizenship als Bedingung politischer Partizipation wird Frauen nur reduziert gewährt. Zweitens sind neben der geschlechtsspezifischen Arbeitsteilung auch die Arbeitsbedingungen im Berufsfeld Politik sowie die kulturellen Konstruktionen von Politik und Politischem als männliche Arbeit mit der Lebensplanung von Frauen nicht kompatibel. Drittens sind es die Strukturen von Parteien und deren „Boy's Club“-Vorurteile die politisches Engagement von Frauen und ihre staatsbürgerliche Vollmitgliedschaft behindern. Darüber hinaus wirkt viertens das kulturelle Muster der unpolitischen und politisch desinteressierten Frau.

„Frauen gelten als die ,schlechteren Demokratinnen', weil sie im Vergleich zu Männern weniger Punkte auf der Partizipationsskala zu verzeichnen haben und in geringerem Maße als Männer die ihnen von der parlamentarischen Demokratie zur Verfügung gestellten Handlungsräume nutzen. Dies läge (...) schlicht am geringeren Interesse von Frauen an der Politik. Dieses ihr geringes politisches Interesse gilt als eine Hauptursache für die niedrige Wahlbeteiligung, für das geringe konventionelle Engagement und für die politische Unterrepräsentation von Frauen" (Sauer 2001: 210).

Zum Abbau dieser Barrieren lassen sich folgende drei Lösungsansätze identifizieren: Diejenigen Zugangserschwernisse für Frauen, die mit der geschlechtsspezifischen Arbeitsteilung in Produktion und Reproduktion zusammenhängen, können erst dann aufgelöst werden, wenn Frauen und Männer den gleichen vollen Umfang von bezahlter und unbezahlter Arbeit übernehmen. Es bedarf also einer Neu-Konzeptualisierung der geschlechtshierarchischen Arbeitsteilung. 
Die Probleme der Arbeitsbedingungen von PolitikerInnen und daraus resultierenden Vereinbarkeitsproblematiken von Beruf und Familie würden eine umfangreiche Modifizierung benötigen, um Menschen die Möglichkeit zur aktiven Elternschaft gewähren zu können. Politisch formuliert: Volle StaatsbürgerInnenschaft für Frauen ist nur durch die Überwindung der geschlechtsspezifischen Arbeits- und der Sphärentrennung zwischen öffentlich und privat möglich. Die „Boy's Club"-Vorurteile, die das Auswahlverfahren von Parteien oder von WählerInnen prägen, machen spezielle Aktionen gegen Diskriminierung, wie beispielsweise Quoten, nötig, um die Wahl von Frauen zu fördern (vgl. Phillips 1993: 106).

Frauen sind nicht unpolitisch, „sondern sie sind mit den Formen traditioneller Politik unzufrieden, sie distanzieren sich zunehmend bewusst von konventioneller Politik, mehr noch: sie verweigern sich - in einer Art rationalem Wahlverhalten - formalisierter politischer Partizipation" (Sauer 2001: 213). Für Frauen gelten scheinbar andere „Bedingungen politischer Beteiligung, und sie präferieren andere Partizipationsformen als Männer" (ebd.: 214). Das Bild der politisch desinteressierten Frau taugt „viel eher dazu, Frauen aus dem politisch-parlamentarischen Raum nachhaltig auszuschließen als ihre politischen Einstellungs- und Verhaltensmuster zu erklären" (ebd.: 212).

Zusammenfassend können in der feministischen Forschung folgende Problemfelder des Staatsbürgerkonzepts identifiziert werden: „The demanding nature (...) which has particular implications for women, disadvantaged by the sexual division of time; its narrow conception the political built on a, generally, rigid separation of public and spheres; and its uncritical appeal to notions of universalism, impartiality and the common good. An important element of any feminist citizenship project is to define both citizenship and the political in broad terms so as to encompass the kind of informal politics in which women often take the lead and the struggles of oppressed groups generally" (Lister 1997: 9).

Doch nicht nur die politisch-demokratischen Strukturen und Institutionen wirken einer vollständigen Realisierung des Citizenship-Status von Frauen entgegen, die klassisch-liberale Vorstellung von StaatsbürgerInnenschaft selbst zeichnet sich durch einen männlichen Bias aus: „Der Staatsbürgerstatus ist an männlich gedachten Lebens- und Politikerfahrungen orientiert" (Sauer 2003a: 10). So war es historisch die Waffenfähigkeit, die politische Staatsbürgerrechte verlieh.

Carole Pateman zeigte beispielsweise für Amerika, dass die politische Mitgliedschaft für Männer durch ihren Status als Soldaten, für Frauen dagegen durch ihren Status als Mütter gekennzeichnet war. Nur jene Personen, „die als bereit und in der Lage galten, den Staat mit der Waffe zu verteidigen - davon waren die nicht-waffenfähigen Frauen und anderen Staaten verpflichtete Personen, also Nicht-Staatsangehörige, ausgeschlossen - wurden zum politischen Gemeinwesen gerechnet und erhielten das Recht auf politische Mitwirkung“(ebd.): „Hist- 
orically, men as a group have been tied to citizenship through their soldiering, and thus always have been treated as having stronger claims for political and social citizenship" (Lister/Hobson 2001: 7). Mit der historischen Ausdehnung ziviler, politischer und sozialer Staatsbürgerschaft auf immer mehr Personengruppen eines politischen Gemeinwesens ist der Gedanke der Universalisierung von Citizenship verknüpft. Die Universalität des Staatsbürgerstatus schließt ein, dass „dieser Status Partikularität und Differenz transzendiert. Ganz gleich welche sozialen Unterschiede oder gruppenspezifische Differenzen es unter den Bürgern geben mag, welche Ungleichheiten bezüglich Reichtum, Ansehen und Macht im sozialen Alltag der Zivilgesellschaft vorhanden sein mögen, in der politischen Öffentlichkeit verleiht der Staatsbürgerstatus jedem den gleich Status als einem Gleichgestellten. Gleichheit wird als Gleichsein aufgefasst" (Young 1993: 267).

Doch produziert gerade die Idee eines universellen, für alle gleich gültigen Staatsbürgerstatus politische Ungleichheit, da die maskulinistischen Grundannahmen politischer Staatsbürgerschaft keineswegs beseitigt wurden. Hierfür können zwei Beispiele genannt werden:

Erstens wird der vermeintlich geschlechtslose Staatsbürger als Nutzen maximierendes und rational agierendes, allein im Sinne seiner Interessenrealisierung entscheidendes, unabhängiges Individuum gedacht. Der Aktivbürger ist damit von jeglichen sozialen Bezügen, Kontexten und Abhängigkeiten entkoppelt. Diese Negation von Abhängigkeit ist eine männliche Fiktion, die darauf basiert, dass es ein Komplement gibt - eine abhängige und daher öffentlichkeits- und politikuntaugliche Frau (vgl. Sauer 2003a: 10). Zweitens werden Interessen im Konzept des Citizenship als gegeben aufgefasst und werden nur durchgesetzt beziehungsweise repräsentiert. „Diese essentialisierende Interessen-Idee setzt nun aber genau jene Bedürfnisse, die dem männlichen Individuum zu Eigen sind nämlich ökonomische Interessen in einer von der Privatheit geschiedenen Sphäre - als universale Interessen voraus" (ebd.). Demgegenüber sollte die Herausbidung von Interessen selbst als ein zutiefst politischer und geschlechtsspezifischer Prozess gesehen werden, der durch gegebene staatsbürgerliche Rechte insbesondere durch Wahlen - kein politisches Gewicht erhält (vgl. ebd.).

Politische und soziale StaatsbürgerInnenschaft hängen also, wie Marshall herausarbeitete, unmittelbar zusammen. Und eine Bestimmung des politischen Status sollte mithin die Geschlechterdifferenz einbeziehen. „In short (...) a genuinely democratic citizenship would require that both sexes are full citizens and that their citizenship is of equal worth to them as women and men" (Squires 1999: 188). StaatsbürgerInnenschaft als Maßstab muss so umgestaltet werden, dass der falsche Universalismus nicht mehr ausschließlich männlich Interessen bevorzugt: „Key (...) is the reconstruction of citizenship's yardstick so that it no longer privileges the male through its false universalism" (Lister o.J: 9). 
Es existieren mittlerweile eine Reihe von Ansätzen eines Prozesses des „regenderings" von Staatsbürgerschaft. Diese lassen sich anhand von drei normativen Bildern kategorisieren (vgl. Lister/Hobson 2001: 21 ff, Lister o.J: 4ff):

- Gender-neutral citizen: Dieser erste Ansatz arbeitet mit dem Modell, dass Frauen und Männer gleich sind und fordert eine Inklusion von Frauen in das StaatsbürgerInnenkonzept basierend auf ihrer Gleichheit zu Männern. Hauptaugenmerk liegt auf den gleichen Rechten und Verpflichtungen, wobei das Geschlecht der Individuen irrelevant bei der Allokation und Ausübung dieser Rechte und Pflichten ist. Priorität ist, Frauen dazu zu befähigen zu gleichen Bedingungen mit Männern in der politischen Sphäre sowie am Arbeitsmarkt konkurrieren zu können. In der politischen Sphäre wird auf eine volle und gleiche Partizipation von Frauen in der formalen Politik Wert gelegt, „first through the winning of the vote and then through formal political representation. Women's representation in parliament and government has been pressed as a matter of equality and justice rather than as a means of promoting a particular set of interests or a different way of doing politics" (Lister o.J: 5). Da die sozialen Rechte der StaatsbürgerInnenschaft mit dem Arbeitsmarktstatus anhand von Sozialversicherungssystemen verbunden sind, ist die Intention jene, Frauen in gleicher Weise wie Männer in den Bereich der Erwerbsarbeit einzubinden, denn dies wiederum öffnet den Zugang zu den sozialen Rechten. Die Erreichung ökonomischer Unabhängigkeit wird als notwendig für eine volle und effektive StaatsbürgerInnenschaft verstanden.

- Gender-differentiated citizen: Dieses Modell geht davon aus, dass eine Differenz zwischen Frauen und Männern besteht. Die entsprechenden Forderungen wurzeln in einer weiblichen Andersartigkeit und aus der Mutterschaft resultierenden weiblichen Qualitäten und Werte. Die Hauptforderung ist eine Transformation des Konzeptes der StaatsbürgerInnenschaft um den Erfahrungen von Frauen entgegenzukommen: „It is a model that appeals to ,difference' not ,equality' in promoting women's claims as social and political citizens" (Lister/Hobson 2001: 23). Dies wird historisch zumeist mit maternalistischen Argumenten verbunden - ,difference was embodied in motherhood" (ebd.) - beispielsweise indem darauf verwiesen wurde, dass Frauen als Mütter andere Qualitäten und Werte in die politische Sphäre bringen. Heute wird eher anhand einer nicht-maternalistischen Konzeption von Differenz argumentiert, ,around the broader notion of care and an ethic of care, which is not confined to women" (ebd.: 24). Hierbei liegt das Hauptaugenmerk auf der Eingliederung von CareArbeit in die Definition von StaatsbürgerInnenschaft.

- Gender-pluralist citizen: In diesem dritten Modell werden beide - Frauen und Männer - als Mitglieder von ,multiple groups and as holders of mul- 
tiple identities“ (Lister/ Hobson 2001: 21) verstanden. Dies basiert auf dem Verständnis von Subjekten und ihren Identitäten als durch verschiedene Diskurse konstruiert, die nicht als auf eine Position, sei es Klasse, Rasse oder Geschlecht, reduziert werden können. Die Priorität ist eine Idee von Politik zu artikulieren, die im Sinne von Solidarität und entgegen Unterdrückung, das Netz von Gruppendifferenzen durchqueren kann, ohne sie dabei zu unterdrücken. Hiermit kann die Geschlechter-Binarität ebenso wie die Gleichheit-Differenz-Dichotomie durchdrungen werden, denn ,gender does not stand alone in shaping the contours of citizenship. Gender intersects with other sources of social division such as race, class, sexuality, disability and age" (ebd.: 26).

Vor dem Hintergrund dieser drei Ansätze schlägt Ruth Lister folgende Rekonstruktion von StaatsbürgerInnenschaft vor: Zunächst bedarf ein feministisches Konzept von StaatsbürgerInnenschaft der Eingliederung von Care-Arbeit (vgl. zur unbezahlten Arbeit auch Fußnote 39). Außerdem braucht es eine Synthese zwischen den beiden ersten Modellen - gender-neutral und gender-differentiated citizen - die die langjährige Debatte des Feminismus zwischen Gleichheit und Differenz widerspiegeln (vgl. Kapitel 4.2.1), innerhalb des Rahmens einer Geschlechterpluralität (gender-pluralist citizen). Zentraler Punkt dieser Synthese muss die Zerschlagung der Öffentlich-Privat-Dichotomie sein, ,in recognition of the ways in which the interaction between public and private spheres sculpts the gendered contours of citizenship. From a policy perspective, this means, above all, measures to shift the gendered division of labour and to create the conditions in which both women and men can combine paid work and caring responsibilities. Thus the re-gendering of citizenship will require change in both public and private spheres and in men's as well as women's relationship to citizenship" (Lister 0.J: 9).

\subsubsection{Zivilgesellschaft und die Beteiligung von NGOs}

Ein Konzept, um Partizipation und aktive Staatsbürgerinnenschaft von Frauen zu begründen und zu gestalten ist das der Zivilgesellschaft. „Feministische Demokratisierung kann politisch nicht mehr von einer Vorstellung von Zivilgesellschaft als Gegenkonzept zur durchstaateten repräsentativen Demokratie ausgehen. Analytisch-konzeptuell müssen zivilgesellschaftliche und staatliche Herrschafts- und Gewaltstrukturen als ambivalent ineinander verwobene gesellschaftliche Bereiche verstanden werden, in denen politische Subjekte zu Untertanen werden, in denen sie aber auch politisch - d.h. gemeinsam handeln - ihre Bedürfnisse realisieren und ihre Interessen durchsetzen" (Sauer 2001: 260).

Obwohl ,state institutions and civil society thus stand in a certain tension with one another in their principles of organization (...) democratic politics that aim 
to promote justice need both forms of social activity and they need to be connected with one another" (Young 2000: 157).

In Abgrenzung zu Staat und der Wirtschaft versteht Iris Marion Young Zivilgesellschaft als den dritten Sektor bestehend aus ,associations that are relatively autonomous from both state and economy. They are voluntary, in the sense that they are neither mandated nor run by state institutions, but spring from everyday lives and activities of communities of interest" (Young 2000: 158). Wichtig ist für sie außerdem folgendes Charakteristikum der Zivilgesellschaft: „Activities with a civic purpose aim to serve not only members, but also the wider community. Civic associations claim to make some contribution to the collective life" (ebd.: 161). Dementsprechend kann die Zivilgesellschaft „powerful means of enhanceing democracy and social solidarity" (ebd.: 180) hervorbringen. Sie kann kommunikative Interaktion ebenso fördern wie eine demokratische Inklusion von ausgeschlossenen und marginalisierten Gruppen, indem diese zusammenfinden, Gegenöffentlichkeiten bilden und ihre Meinungen und Perspektiven innerhalb einer größeren Öffentlichkeit ausdrücken können (vgl. Young 2000: 189). Zivilgesellschaft steht so „vornehmlich für die Erweiterung politischer Selbstbestimmung der BürgerInnen gegen den Staat" (Sauer 2003b: 121). Ein dem Staat entgegengesetzter Begriff von Zivilgesellschaft eignet sich jedoch „nicht als emanzipatorisches Konzept um feministische Ziele wie Autonomie, Solidarität, Gleichheit und Gerechtigkeit zu realisieren“" (ebd.: 122). Eine solche „zu simple Dichotomie“ und der naive "Glaube an die herrschaftsfreie Verheißung (...) manövriert die Frauenbewegung (...) möglicherweise in eine politische Sackgasse" (ebd.: 127). In ihrer normativen Bedeutung ist die Zivilgesellschaft ,geschlechterpolitisch problematisch und mithin ,kein Konzept für Frauen' (...) ebenso wenig wie ,der' Staat" (ebd.: 121f). Eine Entgegensetzung der Begriffe Staat und Zivilgesellschaft ist „frauenpolitisch falsch und greift demokratiepolitisch zu kurz" (ebd.: 122), denn damit wird die gegenseitige ,Konstituierung von Staat und Gesellschaft, von politischen Institutionen und politischen Subjekten" (Sauer 2001: 165) unterschlagen. Einem feministischen Projekt stehen laut Birgit Sauer also fünf Probleme dieser dichotomen Konzeptualisierung im Weg:

Erstens sind Zivilgesellschaft und Staat keine Gegensätze, „keine sich widerstreitenden, einander gegenüber stehenden sozialen Räume" (Sauer 2003b: 127). Die Zivilgesellschaft ist nicht frauenfreundlicher, weniger patriarchal als der Staat und auch nicht der bessere Ort um feministische Politik zu realisieren, denn ,die beiden sind vielmehr wie kommunizierende Röhren. Die Wichtigkeit zivilgesellschaftlicher AkteurInnen und Aktionen ergibt sich dann aus dem Kampf um Hegemonie in der Zivilgesellschaft und in ihrem Potential zur Veränderung hegemonialer Staatsverständnisse, von Institutionen und von Normen bzw. Denkweisen“( (ebd.: 128). 
Zweitens erscheint der Staat aufgrund der Entgegensetzung zur Zivilgesellschaft als ,ein monolithisches, in sich konsistentes und homogenes Gebilde. Diese Hypostasierung (...) kann sich auf emanzipatorische Politik in der Zivilgesellschaft selbstblockierend auswirken“ (ebd.).

Drittens ist es falsch anzunehmen, dass ,je weniger Staat es gibt, umso stärker kann sich die Zivilgesellschaft in diesem Vakuum ausdehnen und umso frauenfreundlicher und demokratischer wird die Gesellschaft" (ebd.: 128f). Denn zivilgesellschaftliche Aktivierung muss gerade in einem ,dialektischen Prozess der Transformation staatlicher Strukturen und der Veränderung in der Ökonomie“ (ebd.: 129) erfolgen.

Viertens fehlt dem normativen Zivilgesellschaftskonzept ein Herrschaftsbegriff, während Herrschaft alleine im Staat verortert wird und so soziale Auseinandersetzungen und Widersprüche in der Zivilgesellschaft unterschätzt werden. Auch in der Zivilgesellschaft werden Herrschaftsverhältnisse wirksam und institutionell verfestigt, auch dort muss ,gegen maskulinistische Strukturen argumentiert und gehandelt werden" (ebd.). Demgemäß formieren sich vielfach in der Zivilgesellschaft Herrschaftsverhältnisse und „bilden sich in (staatlichen) Strukturen ab und aus. Konkret bedeute dies, dass ein enger Konnex zwischen Staat und großen Interessensgruppen der Zivilgesellschaft besteht: Der Staat ist in die Zivilgesellschaft ,eingebettet'“ (Sauer 2001: 166). Der Staat kann also nur so frauenfreundlich sein wie die Zivilgesellschaft und umgekehrt, also ist die Zivilgesellschaft nicht an sich ein Konzept für Frauen, „sie muss vielmehr immer wieder zu einem frauenfreundlichen Konzept gemacht werden - gegen männlich-hegemoniale Tendenzen in der Zivilgesellschaft selbst, aber auch gegen Herrschaftsstrukturen zwischen Frauen“" (Sauer 2003b: 132).

Und fünftens ist die „Selbstbezeichnung als ,Zivilgesellschaft' (...) eine Strategie, in der ,das Andere' entsteht und exkludiert wird. Dieser Akt exekutiert Benennungsmacht, er kann deshalb zum Ausschließungsverfahren und Zivilgesellschaft damit elitär und exklusiv werden" (ebd.: 130). Feministische Anliegen haben daher nur dann eine Chance, wenn sie ,institutionen- und strukturkritisch die bestehenden Formen auf ihre implizierten Exklusionsstrategien hin analysieren und die in Formen geronnenen patriarchalen Spielregeln entschlüsseln und skandalisieren"(Lang 1994: 224).

Auch Shirin M. Rai argumentiert gegen eine Dichotomie von Staat und Zivilgesellschaft und klärt deren Beziehung anhand von drei Faktoren (vgl. Rai 2003: 32f): Zunächst ist es wichtig die konstituierenden Elemente der Zivilgesellschaft ,including the system of needs (the market), the system of rights (the law) and non-state associations" (ebd.: 32) zusammenzuführen. Außerdem ist es ebenso wichtig die ausschließenden Aspekte der Zivilgesellschaft ,in relation to those who find no place in its system of needs or in its associational life" (ebd.: 33) zu beleuchten. „Third, in terms of the civil society-state relation, we should empha- 
size the importance of the state beyond simply maintaining (or not maintaining) the parameters of civil society itself, and of politics in mediating between the particular interest of civil society and the universalist claims of the state" (ebd.).

Daher stellt sich gerade feministisches Engagement in der Zivilgesellschaft als ein „,paradoxes' Unterfangen mit und gegen den Staat" dar und braucht sechs staatliche Bedingungen damit sie „leben kann" (Sauer 2003b: 133). Zunächst bedarf es eines social, economic und political citizenship für Frauen. Dies beinhaltet geschlechtsspezifische Ausgestaltung von sozialen BürgerInnenrechten, Recht auf Arbeit, sowie politische Beteiligungsangebote für Frauen (vgl. ebd.: 133 und auch Kapitel 4.2.3). Außerdem braucht es eine Machtteilung beziehungsweise -verlagerung weg von den privilegierten AkteurInnen hin zu bislang Benachteiligten ebenso wie eine institutionelle und eine geschlechterbewusste finanzielle Stärkung zivilgesellschaftlichen Engagements (ebd.).

Auch Young unterstreicht, dass eine demokratische Gesellschaft und eine Politik, die Gerechtigkeit fördern möchte, Zivilgesellschaft und Staat braucht, denn „state and civil society are both necessary elements in a democratic process that aims to do justice“ (Young 2000: 190). Sie argumentiert grundsätzlich sogar für eine Assoziative Demokratie, deren Idee eine stärkere Verlinkung zivilgesellschaftlicher Institutionen mit staatlichen Institutionen ,in formal processes of decision-making, representation and review" (ebd.: 194) ist. Young ist sich aber auch der Gefahr bewusst, dass zivilgesellschaftliche Initiativen sobald sie stärker an staatliche Autoritäten gebunden sind ihre Unabhängigkeit verlieren könnten und damit auch das Potential "to hold state institutions accountable to citizens“ (ebd.: 195).

Zusammenfassend ist anzuführen, dass Zivilgesellschaft dann ein Konzept für Frauen sein kann, wenn sie den Raum für Partizipation und Selbstvertretung von Frauen und damit für Frauenthemen öffnet und ,wenn sie sich am Grundsatz der Frauenbewegung. Das Private ist politisch' orientiert, und daher die Trennung von ,privat' und ,öffentlich' überwindet. Wenn sie eigene sexistische und androzentristische Strukturen reflektiert, und daher Frauen einen gleichberechtigten Zugang zu Öffentlichkeit und Leitungsfunktionen garantiert. Wenn sie die hierarchische Aufteilung von Produktions- und Reproduktionsarbeit überwindet, und daher Arbeit im reproduktiven Bereich enttrivialisiert. Wenn sie staatliche Basisfinanzierung für Frauenprojekte durchsetzt, und wenn sie Frauen nicht als einheitliches Subjet imaginiert" (Appel et al 2001: 37f).

Die Zivilgesellschaft ermöglicht es „Frauen, als politische Subjekte gestaltend teilzunehmen und Gesellschaft immer wieder feministisch und innovativ zu verändern. Doch auch das muss erkämpft werden" (Appel et al 2003: 15). Somit ist auch die Zivilgesellschaft „vom Demokratisierungserfordernis nicht freigestellt" (Abels/Sifft 1999: 28) und „partizipatorische öffentliche Artikulation und Einfluss auf staatlich-politische Institutionen“ müssen „mit dem Ziel aufeinander 
bezogen werden, Inklusion nicht nur als Option zur öffentlichen Betätigung, sondern auch als reale Chance zur Durchsetzung politischer Strategien zu entwickeln“(Lang 1994: 224).

\subsubsection{Partizipatorische Parität}

Nancy Fraser formuliert die Frage nach den Bedingungen zur Teilnahme an einer demokratischen Debatte etwas anders und postuliert eine Bedingung, die sie „partizipatorische Parität" nennt. Sie geht davon aus, dass Verteilungsgerechtigkeit eine notwendige, aber keine hinreichende Bedingung für politische Deliberation ist, denn die zugrunde liegende „reduktive, zugleich ökonomistische und legalistische Auffassung des Status“ impliziert, dass ,eine gerechte Verteilung von Ressourcen und Rechten schon dazu hinreicht, mangelnde Anerkennung von vornherein auszuschließen" (Fraser 2003: 51). Doch ist nach Fraser „nicht jede Form mangelnder Anerkennung das Nebenprodukt einer unfairen Verteilung oder der Kombination von unfairer Verteilung mit rechtlicher Diskriminierung“"(ebd.: 51f).

Daher muss eine Theorie der Gerechtigkeit „über die Verteilung von Rechten und Gütern hinausgehen, um auch institutionalisierte Schemata kultureller Bewertung berücksichtigen zu können“ (ebd.: 52). Fraser schlägt daher „eine zweidimensionale Konzeption von Gerechtigkeit" (ebd.: 54) vor. Diese versteht „Verteilung und Anerkennung als unterschiedliche Dimensionen und Aspekte der Gerechtigkeit. Ohne eine Dimension auf die andere zu reduzieren, umfasst sie beide innerhalb eines breiten Rahmens" (ebd.). Der normative Kern dieser Konzeption besteht in der „Vorstellung einer partizipatorischen Parität" (ebd.). Der Begriff Parität bezeichnet nach Fraser „die Bedingung, eine Gleiche bzw. ein Gleicher zu sein, also gleichberechtigt mit anderen zu sein und von derselben Grundlage auszugehen (...) die moralische Notwendigkeit [besteht] darin, dass den Gesellschaftsmitgliedern die Möglichkeit der Parität garantiert wird, ganz gleich, ob und wann sie sich dazu entschließen, an einer bestimmten Betätigung oder Interaktion zu partizipieren. Es ist nicht erforderlich, dass tatsächlich jeder an solch einer Aktivität partizipiert" (Fraser 2003: 54f, Fußnote).

Der Norm der partizipatorischen Parität zufolge „erfordert die Gerechtigkeit gesellschaftliche Vorkehrungen, die allen (erwachsenen) Gesellschaftsmitgliedern erlauben, miteinander als Ebenbürtige zu verkehren" (ebd.: 54f). Hierfür müssen mindestens zwei Bedingungen erfüllt sein: „Zum einen muss die Verteilung materieller Ressourcen die Unabhängigkeit und das "Stimmrecht" der Partizipierenden gewährleisten“ (ebd.: 55). Dies benennt Fraser als die „objektive Bedingung partizipatorischer Parität" (ebd.), welche von vornherein diejenigen Formen und Ebenen ökonomischer Abhängigkeit und Ungleichheit ausschließt, die eine Parität der Beteiligung erschweren. Ebenso ausgeschlossen sind gesellschaftlichen Strukturen, „die Verelendung, Ausbeutung und schwerwiegende 
Ungleichheiten in Sachen Wohlstand, Einkommen und Freizeit institutionalisieren und dabei einigen Menschen die Mittel und Gelegenheiten vorenthalten, mit anderen als Ebenbürtige zu interagieren" (ebd.). Diese Bedingung bringt die Anliegen der Theorie der Verteilungsgerechtigkeit zur Geltung.

Die zweite Bedingung, die Fraser ,intersubjektive Bedingung partizipatorischer Parität“ nennt, verlangt, dass ,institutionalisierte kulturelle Wertmuster allen Partizipierenden den gleichen Respekt erweisen und Chancengleichheit beim Erwerb gesellschaftlicher Achtung gewährleisten“ (ebd.). Daher schließt sie von vornherein alle institutionalisierten Wertschemata aus, die ,einigen Leuten den Status eines vollberechtigten Partners in der Interaktion vorenthalten - sei es, indem ihnen in übertriebenem Maße eine „Andersartigkeit“ zugeschrieben wird, sei es, indem man es versäumt ihnen ihre Besonderheit zuzubilligen" (ebd.). Diese Bedingung bringt wiederum die Anliegen der Philosophie der Anerkennung zum Ausdruck.

Der dargestellte Ansatz dehnt das übliche Verständnis von Gerechtigkeit so weit aus, dass sowohl intersubjektive als auch objektive Perspektiven eingeschlossen werden und bringt sie überdies - indem er Umverteilung und Anerkennung als die beiden Dimensionen der umfassenden Norm partizipatorischer Parität unterstellt - ,in den Anwendungsbereich eines einzigen, normativ einheitlichen Rahmens" (ebd.: 56). Die partizipatorische Parität dient des Weiteren dazu, vorgeschlagene Strategien gegen Ungerechtigkeit zu bewerten. „Ob sie nun Umverteilung oder Anerkennung fordern, in jedem Fall müssen die Anspruchstellenden zeigen, dass die von ihnen angestrebten gesellschaftlichen Veränderungen tatsächlich die partizipatorische Parität befördern werden" (ebd.: 58). Diejenigen die Umverteilung fordern, müssen zeigen dass die mit ihr verbundenen Wirtschaftsreformen „Bedingungen für eine vollwertige Beteiligung derjenigen unterstützen werden, denen sie bislang vorenthalten wurde - und dies, ohne im selben Zuge bestehende Disparitäten zu verschärfen oder andere entstehen zu lassen. Auf ähnliche Weise muss, wer Anerkennung fordert, zeigen, dass die von ihm angestrebten soziokulturell wirksamen institutionell getragenen Veränderungen wieder die benötigten intersubjektiven Bedingungen unterstützen werden, ohne dabei die bestehenden Disparitäten signifikant zu verschlimmern, oder gar weitere ins Leben zu rufen" (Fraser 2003: 58).

\subsection{Institutionen und Prozesse (K2)}

\subsection{1 Öffentlichkeit und Deliberation}

Einer der Ansatzpunkte der neuen Frauenbewegung und politikwissenschaftlicher Geschlechterkritik war die Kritik an der Trennung zwischen öffentlicher und privater Sphäre, denn die Trennung dieser beiden Sphären wurde als „zen- 
traler patriarchaler Modus zur Konstruktion hierarchischer Zweigeschlechtlichkeit und zur Legitimierung des Ausschlusses und der Unterordnung von Frauen entlarvt" (Sauer 2001: 184). Denn die Grenzziehung zwischen Öffentlichkeit und Privatheit hat als ein zentraler patriarchaler Herrschaftsmodus historisch eine Reihe ,von Konventionen, Regeln und Institutionen geschaffen, die Frauen der Privatheit, Männer hingegen der Öffentlichkeit und der Politik zuordneten, also die gesellschaftlichen Sphären geschlechtsspezifisch kodierten und hierarchisierten" (Sauer 2001: 188f).

Im politikwissenschaftlichen Sprachgebrauch bezeichnet Öffentlichkeit hierbei „erstens alles, was den Bereich staatlicher Willensbildung und Entscheidung anlangt, zweitens jenen Raum bzw. jene Handlungen, die ein Korrelat und Gegengewicht zum institutionell verfassten Staatsleben bilden. Öffentlichkeit ist das Forum politischer Artikulation und Partizipation" (Sauer 2001: 315, Fußnote 15). Privatheit als Gegenpol wird zum einen als ein „quasi-natürlicher, vordiskursiver und damit die politisch-staatliche Sphäre gefährdender Bereich" und zum anderen als eine „vor staatlichen Übergriffen zu schützende Sphäre des familiären, verwandtschaftlichen oder freundschaftlichen Zusammenlebens" (Sauer 2991: 192) verstanden. Folglich bleibt all das, was mit dem Geschlecht zu tun hat, nicht-öffentlich, wird geheim gehalten und „definitorisch, ideologisch und real in die Privatheit abgeschoben" (Sauer 2001: 193). Dadurch verschwindet Geschlecht als Faktor des Politischen und die Öffentlichkeit wird maskulinisiert: „Bürger kann der Mensch/Mann nur in der Öffentlichkeit sein“ (Sauer 2001: 189).

Die feministische Politikwissenschaft hat dementsprechend herausgearbeitet, dass sowohl Öffentlichkeit als auch Privatheit als relationale Begriffe verstanden werden müssen, denn sie sind zeit- und ortsspezifisch, „also kulturell definiert“ und „historisch wandelbar" (Sauer 2001: 194). „Privatheit ist ebenso wie Öffentlichkeit eine vorgestellte, eine imaginierte Größe oder besser gesagt: ein hegemonialer Diskurs. Die Trennung von öffentlich und privat fungiert als ein Organisations- und Wahrnehmungsmuster von Realität, von Politik und Gesellschaft, das soziale Beziehungen reguliert, das erlaubt, gestattet und verbietet. Die Dichotomie regelt den Zugang zu bestimmten Räumen bzw. Ressourcen, sie bildet Identitäten und Akteursgruppen heraus und sie organisiert Interessen“ (Sauer 2001: 194).

In den 1990er Jahren wurde Öffentlichkeit zu einem der Zentralbegriffe einer normativen demokratietheoretischen Debatte, die das Kernproblem von Demokratisierung in der Institutionalisierung sowie Re-Institutionalisierung des öffentlichen Raums sieht. Leitend für diese aktuellen demokratietheoretischen Interventionen wurde Jürgen Habermas' Definition von Öffentlichkeit als eine Sphäre der politischen Debatte und Partizipation jenseits von Familie, Ökonomie und Staat, eine Sphäre die zwischen den gesellschaftlichen Bedürfnissen 
und dem Staat vermittelt (vgl. Sauer 2003a: 14). Angesichts des Zerfalls beziehungsweise der Durchdringung von Öffentlichkeit und Gesellschaft ist das demokratiepolitische Ziel, eine Kolonisierung, also eine Re-Politisierung der staatlich still gestellten politischen Sphäre (vgl. Sauer 2001: 198). Doch auch in diesem empathischen Sinn ist Öffentlichkeit nicht herrschaftsfrei, denn vielmehr entsteht (staatliche) Herrschaft im männlich dominierten öffentlich-kommunikativen, zivilgesellschaftlichen Bereich.

Der feministischen deliberativen ${ }^{44}$ Demokratietheorie geht es deshalb darum, wie ein diskursives Modell von Öffentlichkeit, das nach universalistischen Prinzipien wie beispielsweise gleichem Zugang für alle verfährt, mit einer Artikulation und Anerkennung ebenso wie mit einem Schutz von Partikularität beziehungsweise Differenz verknüpft werden kann (vgl. Cohen 1996: 188).

Hierzu gehört erstens eine Rekonzeptualisierung von Privatheit, denn ,since public and private are correlative terms, it seems obvious that reconstructions of the public from a feminist point of view call for a reconceptualization of privacy" (ebd.: 191). Jean Cohen konstruiert Privatheit als körperliche und psychische Integrität ebenso wie moralische Autonomie: „One's inviolate personality, bodily integrity, psychic processes of identification, and decisional autonomy over the 'territories of the self' deserve protection no matter where one is" (ebd.: 207).

Privatheit ist dann eine notwendige Voraussetzung und Bedingung für eine demokratische Öffentlichkeit (vgl. Sauer 2001: 191). Eine Reformulierung des Privaten muss zwei Aspekte unterscheiden, „nämlich erstens Privatheit als ein Menschenrecht auf Würde sowie körperliche und seelische Integrität und zweitens als die stets riskante und riskierte Freiheit von staatlichen Eingriffen" (ebd.: 197). Die bipolare Dichotomie von öffentlich und privat sollte durch eine ,graduelle Sichtweise von Staat, Öffentlichkeit und Privatheit ersetzt werden“

44 Deliberative Konzeptionen von Demokratie sind um das Ideal öffentlicher politischer Rechtfertigung organisiert. Laut dieses Ideals ist die Rechtfertigung eine Aufgabe der kollektiven politischen Macht auf Basis von freier öffentlicher Argumentation unter Gleichen. Demokratie bildet aus einer deliberativen Sichtweise das Gerüst an sozialen und institutionellen Bedingungen, das eine freie Diskussion zwischen gleichen BürgerInnen ermöglicht. Die Teilnehmenden am demokratischen Prozess bieten Vorschläge an wie Probleme am besten zu lösen sind oder wie legitimierte Bedürfnisse befriedigt werden können. Diese Vorschläge präsentieren sie und versuchen andere von ihren Argumenten zu überzeugen damit die jeweiligen Vorschläge angenommen werden. Die Institutionen müssen so arrangiert sein, dass das was als gemeinsames Interesse erachtet wird Resultat von Prozessen kollektiver Deliberation freier und gleicher Individuen ist. Der demokratische Prozess ist damit primär eine Diskussion von Problemen, Konflikten, Bedürfnissen und Interessen (vgl. Benhabib 1996: 69, Cohen 1996: 99, Young 2000: 22). Deliberation ist demgemäß ein demokratische Modell, ,in dem die Verhandlung selbst zur Verhandlung steht" (Holland-Cunz 1998: 173). 
(ebd.), damit die beiden reformulierten Dimensionen nicht wiederum geschlechterideologisch zu einer politischen Ausgrenzung von Frauen verwendet werden. Dann ist Privatheit kein der Öffentlichkeit entgegengesetzter Bereich mehr, sondern umfasst vielmehr diejenigen Beziehungsmuster, die dem öffentlichen Diskurs entzogen sind: „The concept of a heterogeneous public implies two political principals: (a) no persons, actions, or aspects of a person's life should be forced into privacy; and (b) no social institutions or practices should be excluded a priori from being a proper subject to public discussion and expression" (Young 1993: 120).

Außerdem erscheint Privatheit mit der Dekonstruktion des hegemonialen Diskurses ,als ein Aspekt von Öffentlichkeit und Staat. In normativer Sicht ist die Privatsphäre jene Dimension öffentlichen Handelns, die den Individuen anheimgestellt ist, die in ihrer Autonomie liegen, dadurch aber nicht prinzipiell der öffentlichen Debatte entzogen ist. Eine unabdingbare Voraussetzung für die (Neu) Bestimmung von Privatheit ist es, dass Individuen selbst darüber bestimmen können, was sie öffentlich diskutieren wollen und was staatlich reguliert bzw. dereguliert werden soll. Dies nenne ich ,Ver-Öffentlichung des Privaten"“ (Sauer 2001: 197). Öffentlichkeit entsteht demgemäß ebenso in Diskursen, in denen ,um Interessen-Hegemonie gerungen wird und wo feministische Gegendiskurse nur durch die Transformation der politischen Regulierung eine Chance erhalten" (Sauer 2001: 200). Eine Feminisierung von Öffentlichkeit beginnt mit einem ,challenging unexamined normative dualisms as between justice and the good life, norms and values, interests and needs, from the standpoint of their gender context and subtext" (Benhabib 1998: 92). Öffentlichkeit ist dementsprechend kein Ort wie das Parlament, die Straße oder eine Zeitung, denn dann wären private Orte per definitionem ausgeschlossen. Öffentlichkeit ist vielmehr jener Raum, wo Macht und Herrschaft thematisiert und kritisiert werden können: „Öffentlichkeit bezeichnet die ,Möglichkeitsstruktur' politischen Handelns. Diese Möglichkeit ergibt sich in unterschiedlichen sozialen Räumen: am Arbeitsplatz, in der Familie, in der Privatheit" (Sauer 2001: 200). In diesem Sinne können verschiedene soziale Räume „become the locus of public space if they are reflexively challenged and placed into question from the standpoint of the asymmetrical power relations governing them" (Benhabib 1998: 71) und ,the line between the public and the private (...) can be renegotiated, rethought, challenged and reformed" (Benhabib 1996: 83).

Zweitens bedarf eine feministische deliberative Demokratietheorie und ihr geschlechtersensibles Modell einer kommunikativen Demokratie, so Iris Marion Young, folgender normativer Ideale ,for the relationship and dispositions of deliberating parties" (Young 2000: 23):

- Inklusion: Eine demokratische Entscheidung ist normativ nur dann legitimiert, wenn alle die von ihr betroffen sind, in den Prozess der Diskussion 
und Entscheidungsfindung einbezogen sind. Betroffensein bedeutet in diesem Zusammenhang, dass die Entscheidungen oder Politiken die Handlungsoptionen einer Person signifikant bestimmen oder gestalten.

- Politische Gleichheit: Im normativen Ideal meint Demokratie politische Gleichheit. Dementsprechend sollen alle Betroffenen nicht nur nominal in Entscheidungsfindungen eingebunden werden, sondern auch zu gleichen Bedingungen, ,the ideal model of deliberative democracy, that is, promotes free and equal opportunity to speak (...) participations in an ideal process of deliberative democracy must be equal in the sense that none of them is in a position to coerce or threaten others into accepting proposals" (Young 2000: 23).

- Vernünftigkeit: „Reasonable people have crazy ideas; what makes them reasonable is their willingness to listen to others who want to explain to them why their ideas are incorrect or inappropriate" (Young 2000: 24). Vernünftige Menschen begeben sich in eine Diskussion, in denen kollektive Probleme gelöst werden sollen mit dem Ziel eine Einigung zu erreichen.

- Pluralität: Da sich die Öffentlichkeit aus Menschen mit unterschiedlichsten individuellen und kollektiven Erfahrungen, Geschichten, Verpflichtungen, Idealen, Interessen und Zielen zusammensetzt, müssen diejenigen die in dieser Öffentlichkeit auftreten, genau diese Pluralität im Hinterkopf behalten. ,This plural public-speaking context requires participants to express themselves in ways accountable to all those plural others (...) they [should] speak with the reflective idea that third parties might be listening" (Young 2000: 25).

Zentrales Element in öffentlichen Diskussionen sind der deliberativen Demokratietheorie zufolge Argumente. Young geschlechtersensible kommunikative Demokratie jedoch begrenzt die rationale Kommunikation nicht nur auf Sprachakte. Ein rationaler Diskurs muss vielmehr auch Emotionalität, Gestik und Mimik in Betracht ziehen. Neben dem Argument benötigt eine kritisch-kommunikative Öffentlichkeit zusätzlich ,greeting, rhetoric and narrative [storytelling (Young 1996: 131)]“" (Young 2000: 56f):

- Greeting (Public Acknowledgment): In dem Moment von Kommunikation, das Young als „Greeting“ bezeichnet, kündigt ein/e SprecherIn ihre/ seine Präsenz als bereit an zuzuhören und die Verantwortung zu übernehmen für die Beziehung zu den GesprächspartnerInnen, gleichzeitig aber auch die Distanz zu den anderen, also ihre nicht reduzierbare Partikularität. „Greetings in this broad sense are a constant aspect of everyday communication interaction. Without these gestures of respect and politeness, that are only Saying without anything said" (Young 2000: 59). 
„Greetings” von Young auch als „Public Acknowledgment” bezeichnet, benennen die kommunikativen politischen Gesten durch die diejenigen, die miteinander im Konflikt um die Lösung eines Problems stehen, die jeweils anderen - vor allem diejenigen die andere Meinung, Interesse oder sozialer Position sind - als TeilnehmerInnen der Diskussion anerkennen: „Participants acknowledge that the others they adress are part of the process, and that we who address them must be accountable to them, as they to us" (ebd.: 61). Hierbei geht es also darum, dass die Teilnehmenden einer öffentlichen Diskussion nicht nur Vorschläge und Argumente vortragen, die andere akzeptieren können, sondern auch darum, dass sie explizit die anderen, die sie überzeugen wollen, anerkennen: Es muss Platz geschaffen werden ,for care-taking, deferential, polite acknowledgement of the Otherness of others" (ebd.: 130).

Rhetoric: Das Konzept der Rhetorik unterstellt eine Unterscheidung zwischen dem was ein Diskurs sagt, also seinem substantiellen Gehalt oder seiner Botschaft, und dem wie dies gesagt wird. Young versteht Rhetorik als die verschiedenen Varianten wie etwas gesagt werden kann um den Inhalt $\mathrm{zu}$ formen und zu färben. Rhetorik beinhaltet in diesem Sinne folgende Kommunikationsaspekte, die einander überlappen und miteinander auftreten können:

Erstens mangelt kein Diskurs an Emotionen und Ausdrücken von Leidenschaft, sei dies Angst, Hoffnung, Ärger oder Freude.

Zweitens gibt es in Diskursen verschiedene Sprachfiguren wie beispielsweise Metaphern, Wortspiele, u. a. Diese werden von verschiedenen Stilen und Verhaltensmustern begleitet, wie zum Beispiel ein humoristisches, ein ironisches, ein spottendes oder auch majestätisches Verhalten.

Drittens involviert die Art und Weise einen Punkt zu machen nicht nur die Sprache, sondern auch visuelle Medien, Zeichen, Symbole. „All these affective, embodied, and stylistic aspects of communication, finally, involve attention to the particular audience of one's communication, and orienting one's claims and argument to the particular assumptions, history, and idioms of that audience" (Young 2000: 65).

Gerade in politischen Kommunikationen spielt die Rhetorik eine große Rolle, weil gerade der Sinn eines Diskurses stark von ihr abhängt. Demgemäß hat die Rhetorik laut Young drei wesentliche positive Funktionen in der politischen Kommunikation: Zunächst helfen rhetorische Praktiken oft einen Gegenstand auf die Tagesordnung einer Diskussion zu bringen Beispiele wären Demonstrationen oder Proteste. Außerdem können mit Hilfe der Rhetorik Forderungen und Argumente so gestaltet werden, dass sie einer bestimmten Öffentlichkeit in einer bestimmten Situation angemessen sind, denn durch sie kann der Sprechende eine Verbindung mit den Zuhörenden aufbauen. Zusätzlich dazu kann Rhetorik ,the move from 
reason to judgment" iniitieren, „the good rhetorician is one who attempts to persuade listeners by orienting proposals and arguments towards their collective and plural interests and desires, inviting them to transform these in the service making a judgment together" (ebd.: 69).

- Narrative (and Situated Knowledge): Politisches Geschichtenerzählen kann auf verschiedene Art in einer Diskussion über Differenzen helfen. Erstens kann es als eine wichtige Brücke fungieren beispielsweise ,in cases between the mute experience of being wronged and political arguments about justice" (Young 2000: 72). Zweitens kann das Geschichtenerzählen zu einer Identifikation mit einer Gruppe oder einer Affinitätsfindung in einer Gruppe beitragen. Drittens können mit Hilfe von Geschichten die eigenen Erfahrungen und die eigene soziale Situation den anderen leichter verständlich gemacht werden. Viertens können anderen auch die Ursprünge von Werten, Prioritäten und kulturellen Bedeutungen verdeutlicht werden. Und fünftens verbinden Geschichten die Erfahrungen der Beteiligten nicht nur miteinander ,but also present a particular interpretation of their relationship with others (...) thus listeners can learn about how their own position, actions, and values appear to others from the stories they tell"“(ebd.: 76).

Diese drei genannten Kommunikationsweisen können, so Young, die Reichweite einer demokratischen Diskussion erweitern ebenso wie die Art und Weise Probleme und mögliche Lösungen zu sehen verändern. Und „Participants in communicative democracy should listen to all modes of expression that aim to co-operate and research a solution to collective problems" (Young 2000: 80).

\subsubsection{Quantitative politische Repräsentation von Frauen in politischen Verfahren und Institutionen (Soziale Repräsentation)}

Für Nancy Fraser sind Umverteilung und Anerkennung (vgl. Kapitel 4.2.5) alleine noch nicht ausreichend, um in Demokratien Geschlechtergerechtigkeit herzustellen, denn Geschlechtergerechtigkeit muss als dreidimensionale Herausforderung wahrgenommen werden, die Umverteilung, Anerkennung und Repräsentation in gleicher Weise benötigt. Diese dritte Dimension - die Repräsentation definiert Fraser als Sicherstellung einer gleichberechtigten politischen Stimme von Frauen in allen bestehenden politischen Versammlungen repräsentativer Demokratien. Vor dem Hintergrund der Umstrukturierung und der Bildung transnationaler politischer Räume und angesichts der daraus folgenden Tatsache, dass die Wurzeln von Ungerechtigkeit nicht mehr ausschließlich in staatlich-territorialen Kontexten zu lokalisieren sind, erfordert Repräsentation darüber hinaus aber eine Reformulierung von jenen Gerechtigkeitsfragen, die darauf hinweisen, dass sie über etablierte demokratische Strukturen hinausgehen (vgl. Fraser 2005: 305). 
Unterschiedliche analytische Konzeptionen von Repräsentation können anhand folgender Fragen unterschieden werden: Erstens, was wird repräsentiert, wenn jemand behauptet zu repräsentieren? Zweitens wie repräsentiert jemand etwas? Drittens wo wird etwas repräsentiert? Und viertens was ist das Ziel von Repräsentation? Diese Fragen führen im Folgenden zu der Unterscheidung der Konzeptionen von Repräsentation (vgl. Squires 1999: 202ff):

- Ideologische Repräsentation: Ideologische Repräsentation basiert auf dem Konzept der Repräsentation von Ideen und Überzeugungen durch politische Parteien, ,it is the responsible party government model, which requires disciplined parties with alternative programmes on major issues" (Squires 1999: 2002) Kollektive Verantwortlichkeit und Parteiendisziplin sollen gewährleisten, dass RepräsentantenInnen von der Repräsentation der parteilichen Überzeugung nicht abweichen.

- Geographische Repräsentation: Die Repräsentation eines bestimmten Wahlkreises basiert auf dem Konzept der geographischen Repräsentation, welche die Ernennung von Delegierten spezifischer Regionen bedarf. „Here representatives are to act on ways consistent with the opinions of citizens from areas that elect them" (Squires 1999: 202).

- Funktionale beziehungsweise qualitative Repräsentation (vgl. Kapitel 4.3.3): Hierbei handelt es sich um eine Repräsentation von Interessen, die RepräsentantInnen agieren als SprecherInnen von Interessensgruppen und sozialen Bewegungen. Dies wird vielfach auch als qualitative Repräsentation bezeichnet

- Soziale Repräsentation (oder quantitative Repräsentation): Die Repräsentation von Identitäten beruhend auf der sozialen Zusammensetzung der WählerInnenschaft. Die RepräsentantInnen sprechen für eine bestimmte Gruppe, der sie zugehören und deren Erfahrung sie teilen.

Menschen können auf dreierlei Arten repräsentiert werden: Mikrokosmos, symbolisch und nach dem Principal-Agent-Modell. Das Konzept des Mikrokosmos bedeutet, dass die repräsentierende Person Merkmale einer politisch signifikanten Gruppe trägt. Mikrokosmische Repräsentation ist dann der Fall, wenn eine signifikante Untergruppe proportional repräsentiert wird und die Legislative „if it is to be representative, should be a ,mirror' of the nation“" (Squires 1999: 203). Dieses Konzept entspricht der quantitativen oder sozialen Repräsentation.

Die symbolische Repräsentation wird dadurch angezeigt, dass eine Person die Identität oder Qualitäten einer bestimmten Anzahl von Personen repräsentiert, "[t]his sense of representation is invoked in claims that 'a queen represents her people' and does not require (...) shared experiences between represented and representative" (ebd.). 
Eine Principal-Agent-Repräsentation zeichnet sich dadurch aus, dass eine Person die Interessen einer Gruppe beziehungsweise einer Person vertritt: „Principal-agent representation occurs when one person acts on behalf of one other, or when the agent acts in the principal's interests" (ebd.). Dies entspricht einer qualitativen Repräsentation.

Entgegen einer Vorstellung, dass die geringe politische Repräsentanz von Frauen auf ihrer geringeren Partizipationsneigung (vgl. Kapitel 4.2.2) basiert, arbeitete die politikwissenschaftliche Geschlechterforschung die direkten und indirekten strukturellen Repräsentationshindernisse heraus: So besagt die Parteiensystemthese, dass Personalrekrutierungsmuster von Parteien die größte Barriere für eine geschlechtergerechte Repräsentation sind, „männliche Seilschaften oder die Verhinderungsstrategien der politischen Insider gegenüber den politischen Outsidern (weiblichen Geschlechts) bilden neben der Besetzung von Wahllisten und innerparteilichen Aufstiegsmechanismen die höchsten Barrieren für weibliche Repräsentation“ (Sauer 2003: 11). Auch die Wahlsysteme können zu Diskriminierungsstrukturen werden (Wahlsystemthese): So zeigen Forschungsergebnisse, dass das Verhältniswahlrecht die Chancen von Frauen auf ein politisches Mandat erhöht, während das Mehrheitswahlrecht ihre Chancen mindert (Personalisierung) (vgl. Sauer 2003: 12).

Aus feministischer Perspektive stellt sich das Repräsentationsproblem demgemäß folgendermaßen dar: Die über gewählte Repräsentanten nur mittelbare Möglichkeit der Entscheidung erzeugt Verluste auf Kosten von Frauen. Repräsentationsprozesse sind Herrschaftsmechanismen, denn sie sind gegenüber der Vielheit der Bedürfnis- und Interessenlagen selektiv und exklusiv: Prozesse des Sprechens für jemanden sind Herrschaftsmechanismen. Repräsentations- und Wahlverfahren setzen eher (männliche) Partikularinteressen durch, als dass sie helfen Universalität und Chancengleichheit zu realisieren (vgl. ebd.). Demokratisch-repräsentative Verfahren übertragen herrschenden Gruppen Macht, marginalisieren zugleich stimmlose Gruppen und kaschieren aber diesen Herrschaftsmechanismus mit dem Mantel der Universalität (vgl. Phillips 1994: 105). Die existierenden Mechanismen übergeben die effektive Macht dominanten Gruppen und während deren Dominanz als objektive generelle Perspektive dargestellt und als Mehrheitsentscheidung durch nationale Wahlen präsentiert wird, ist die Konsequenz eine fortdauernde Unterdrückung marginalisierter und benachteiligter Stimmen (vgl. Phillips 1993: 116). Das daraus resultierende Grundmuster politischer Repräsentation ,ist eindeutig zugunsten der weißen männlichen Mittelschicht ausgefallen, wobei die Unterrepräsentation der Frauen (die die Hälfte der Bevölkerung ausmachen) lediglich die gröbste in einer ganzen Reihe ausgeschlossener Gruppen ist" (Phillips 1995: 101). Obwohl die repräsentative Demokratie „bereit war, den Fragen vernünftiger Repräsentation und gelegentlicher Kontrolle Beachtung zu schenken“ erweist sie sich bis heute ,als resistent gegen 
jede substantielle Repräsentation von Frauen und in den meisten westlichen Demokratien unsere Tage ist die Anzahl der gewählten Frauen noch immer erschreckend niedrig“" (ebd.: 35 ).

Feministische Demokratietheorien fordern demgemäß mehr Parität zwischen Frauen und Männern in der Politik. Diese Forderung beruht zum Teil ,auf einer Vorstellung von fundamentaler Gerechtigkeit und verbindet sich mit einer ganzen Flut von Argumenten, welche die Geschlechtertrennung in allen Bereichen angreift. Frauen aus dem Zentrum politischen Handelns auszuschließen, ist ebenso ungerecht, wie zu verlangen, dass sie Köchinnen, aber nicht Ingenieurinnen, Sekretärinnen, aber nicht Direktorinnen werden sollen. Angesichts der allumfassenden Bedeutung des Politischen ist es in der Tat ein sehr viel größeres Unrecht, die Frauen davon auszusperren“" (Phillips 1995: 104). Ein Missverhältnis in der Verteilung der Geschlechter unter Wählern beziehungsweise Wählerinnen und Gewählten weist jedenfalls auf ein Problem hin: „Die auffallende Homogenität unserer derzeitigen Repräsentanten beweist das in hinreichendem Maße. Wenn es nämlich keine substantiellen Unterscheide zwischen Männern und Frauen oder Schwarzen und Weißen gäbe, dürften wir erwarten, dass die gewählten Gremien in ihrer Zusammensetzung sehr viel stärker derjenigen ihrer Wählerschaft glichen. Die konstante Unterrepräsentation einer bestimmten gesellschaftlichen Gruppe ist immer Zeichen für ein Problem. Eine so auffallende Abweichung von der Gesamtbevölkerung kann nie Ergebnis eines Zufalls sein" (Phillips 1995: 104f).

Repräsentationssysteme, die Frauen beharrlich nicht selbst das Wort ergreifen lassen, sind nicht nur unfair, sondern erfüllen nicht einmal die Mindestanforderungen von Repräsentation (vgl. Phillips 1995: 105). Unsere politischen RepräsentantInnen vertreten angeblich unsere Standpunkte, sie tragen eine gewisse Verantwortung für ihren Wahlkreis, jedoch ,hinsichtlich der wichtigsten demographischen Merkmale (Alter, Geschlecht, Rasse, Klasse) repräsentieren sie uns keineswegs“ (ebd.: 107). „Solange diejenigen, die für uns sprechen, einer derart unrepräsentativen Auswahl entstammen, wird die Demokratie im Grunde mangelhaft bleiben. Die Hindernisse, die bestimmten Menschen jede Chance nehmen, gewählt zu werden, sind auf ihre Weise ebenso undemokratisch wie die Gesetze, die ihnen einst das Stimmrecht verweigerten. Und wenn wir uns den Tatsachen zuwenden, müssen wir feststellen, dass unterschiedliche Erfahrungen unterschiedliche Werte, Prioritäten und Interessen hervorbringen (...). Wo es verschiedene Interessen und unterschiedliche Erfahrungen gibt, ist die Behauptung eine Gruppe könne für uns alle sprechen, entweder naiv oder unaufrichtig“ (Phillips 1995: 108f).

Frauen sind, auch wenn sie die Mehrheit der Bevölkerung bilden, bezogen auf ihre politischen Partizipationschancen in doppeltem Sinne eine Minderheit: Sie sind in Entscheidungsgremien zahlenmäßig unterrepräsentiert und ihre Zugehö- 
rigkeit $\mathrm{zu}$ allen gesellschaftlichen Gremien und Organisationen wird nicht ausreichend anerkannt. Feministische Alltags-Vermutungen gehen seit Jahren davon aus, dass ein direkter Zusammenhang zwischen der kleinen Zahl und der mangelnden Anerkennung besteht und hoffen, dass Männer in den politischen Öffentlichkeiten und Institutionen Frauen anerkennen werden, sobald sie angemessen repräsentiert sind. Hierbei wird unterstellt, dass „ab einer bestimmten Zahl die Quantität der Repräsentation in die Qualität selbstverständlicher Anerkennung und echter Zugehörigkeit umschlagen wird" (Holland-Cunz 2003: 184). Während eine angemessen Repräsentation von Frauen in den Gremien politischer Entscheidungsfindung zwar eine zentrale und unverzichtbare feministische Forderung ist, ist die ,freiwillige Selbst-Beschränkung auf Strategien der Repräsentation“ (ebd.: 186) äußerst problematisch. Folglich mag es „eine notwendige Bedingung sein, dass mehr Frauen gewählt werden, eine hinreichende ist es fraglos nicht", denn ,die Frage ob Frauen als eine durch gemeinsame Interessen definierte Gruppe gelten können, deren Interessen dann ihrer Vertretung finden müsste" (Phillips 1995: 116) ist damit noch nicht geklärt.

Zusammenfassend besteht also ein Konsens hinsichtlich der Notwendigkeit der gleichen Repräsentation von Frauen in repräsentativen Demokratien, der in Anlehnung an Phillips anhand von vier Argumenten unterstrichen werden kann (vgl. Squires 1999: 204f):

- Rollenmodell-Argument: Dieses Argument basiert auf der Annahme, dass die Existenz von weiblichen Repräsentantinnen andere Frauen dazu ermutigt, auch solche Rollen zu übernehmen.

- Gerechtigkeitsargument: Hierbei wird die gleiche numerische Partizipation von Frauen und Männer als Zeichen von Geschlechtergleichheit interpretiert.

- Das Argument der Interessen von Frauen geht davon aus, dass es innerhalb formaler politischer Strukturen Frauen bedarf, um die Interessen von Frauen zu vertreten.

- Das Argument der Revitalisierung von Demokratie zielt darauf ab, dass die Involvierung von Frauen in der Politik eine Änderung der Politik bedeuten würde.

Das Argument des Rollenmodells und jenes der Gerechtigkeit zielen auf das Problem der gerechten Verteilung von sozialen Ressourcen. Politische Positionen werden als spezielle soziale Ressourcen gesehen, die gerecht verteilt werden sollen und zu denen jede/r Zugang haben sollte. Die ungleiche Verteilung von politischen Positionen deutet darauf hin, dass es strukturelle Barrieren gibt, die spezifischen Gruppen den Zugang erschweren. Im Gegensatz dazu, setzen die beiden anderen Argumente direkter am politischen Prozess an. Das Argument der weiblichen Interessen geht davon aus, dass Frauen als Gruppe der Ge- 
sellschaft gemeinsame Erfahrungen teilen, die bestimmte Interessen und Bedürfnisse mit sich bringen. Dieses Argument hat Frauen nicht als Individuen zum Ausgangspunkt sondern fokussiert auf Frauen als Mitglieder einer Gruppe und geht davon aus, dass Frauen gemeinsame Interessen teilen. Die Forderung nach mehr Repräsentantinnen beruht demgemäß ,teils auf der Vorstellung von partizipatorischer Gleichheit, teils auf der Idee der Widerspiegelung, und dadurch kann weder theoretisch noch praktisch garantiert werden, dass Frauen als Frauen repräsentiert sind. Wir können uns vorstellen, dass eine größere Zahl gewählter Frauen den Kontext und die Prioritäten der Politik verändern werden, aber wir können nicht davon ausgehen, dass dies notwendig der Fall sein oder gar allgemeinen Beifall finden wird“ (Phillips 1995: 129).

Wenn jedoch die Einschränkungen der politischen Aktivität von Frauen auch von ihrer ökonomischen und sozialen Stellung herrühren, ,ist die Vorstellung unsinnig, es könne ein zu gleichen Teilen aus Männern und Frauen bestehendes Parlament ohne gleichzeitig substanzielle Veränderungen in den sozialen Beziehungen geben" (Phillips 1995: 130). Hierbei liegt die Absurdität nicht in der Vorstellung, Frauen würden sich nachher gar nicht mehr von Männern unterscheiden, „,sondern in der Vorstellung, sie könnten solche Machtpositionen je erreichen, bevor diese Veränderungen stattgefunden haben. Eine Demokratie braucht vielleicht die Gleichstellungspolitik vor der Gleichheit der Repräsentation“ (ebd.).

Phillips sieht sich selbst aus einer Tradition kommend, in der „politische Gleichheit stets als Spiegelbild (...) gesellschaftlicher und wirtschaftlicher Gleichheit betrachtet wurde" und kann sich nur schwer vorstellen, dass Frauen und Männer im politischen Bereich gleichberechtigt agieren können, ,solange sich Frauen in einer Position der Abhängigkeit von Männern befinden - und diese Position durch das Zusammenwirken sozialer, wirtschaftlicher und kultureller Kräfte so gefestigt scheint, dass kaum eine Ansatzpunkt für Veränderungen erkennbar wird" (ebd.: 136). Demgemäß liegt die Schwierigkeit der Repräsentation von Frauen als Frauen möglicherweise nicht nur ,an der Schwierigkeit, die gemeinsamen Interessen der Frauen zu bestimmen, sondern auch an dem Problem, Mechanismen einzurichten, mittels derer diese Interessen eine Stimme bekommen" (ebd.: 148).

Es muss jedenfalls anerkannt werden, dass „sich die Gesellschaft aus verschiedenen Gruppen zusammensetzt und diese unterschiedliche Interessen entwickeln können" und „dass die Geschlechter unterschiedlich viel Macht besitzen und deren Verteilung deshalb angeglichen werden muss" (ebd.: 243). Daher ist es gefährlich so zu tun, als wäre es irrelevant wer und was wir sind oder von Menschen zu verlangen, dass sie ihre gruppenspezifischen Unterschiede zugunsten eines abstrakten Konzepts der Bürgerschaft unterdrücken oder darauf zu bestehen, dass Politik nur eine Angelegenheit von Ideen sein soll. Spezifischer be- 
deutet dies, dass die Zusammensetzung der politischen Repräsentantinnen und Repräsentanten sehr wohl einen Unterschied macht und dass wir die notwendigen institutionellen Veränderungen brauchen, die eine Proportionalität zumindest nach Geschlecht und ethnischer Zugehörigkeit gewährleisten. Bestrebungen, mehr Frauen in die Politik zu bringen - um eine Parität zwischen Frauen und Männern herzustellen -, sollten jedoch laut Phillips von jenen Argumenten abgekoppelt werden, die besagen, dass diese weiblichen Repräsentanten dann Frauen als soziale Gruppe repräsentieren sollen. Es geht vielmehr darum, dass unsere Gesellschaft nicht homogen ist, sie strukturiert sich anhand von systematischen Ungleichheiten und wiederkehrender Exklusion. Wir existieren nicht als abstrakte Staatsbürger und Staatsbürgerinnen, sondern als Mitglieder verschiedener privilegierter oder benachteiligter Gruppen. Da politische Organisation auf dominanten gesellschaftlichen Teilungen basiert - aufgrund von Geschlecht, Klasse, Ethnie oder Religion - ist sie ein mögliches Instrument um eine Balance wiederherzustellen (vgl. Phillips 1993: 100f).

Dementsprechend bedeutet für Phillips das Prinzip, an dem sich demokratische Praxis orientieren sollte, dass die RepräsentantInnen die geschlechtliche, ethnische und, falls von Belang, die nationale Zusammensetzung der Gesellschaft insgesamt widerspiegeln sollten und dass es Verfahren mit entsprechender Wirkung geben muss. Eine solche Verhältnismäßigkeit würde sich ohne persönliche Interessen und ohne Strukturen, die den Machterhalt bestimmter Gruppen sichern, von selbst ergeben: Bei ausreichend großer Zahl der Gewählten würden die Prinzipien der Zufallsverteilung genügen, um zu proportionalen Ergebnissen zu kommen. Dass dies bislang noch nie erreicht wurde, zeigt die Notwendigkeit einer Veränderung. Ist eine Gruppe ständig unterrepräsentiert, dann bekommt eine andere Gruppe mehr, als ihr zusteht. „Das Spiegel-Prinzip kann natürlich auch auf andere Bereiche angewandt werden, die gesellschaftlich separiert sind, und es gehört zum Wesen der Politik, dass über die relevanten Gruppen gestritten wird“ (Phillips 1995: 244). Die Verfahren der so genannten Konkordanzdemokratie (consociational democracy) kommen einer Anerkennung dieser Problematik am nächsten und sehen einen Schutz für die Schlüsselgruppen der Gesellschaft vor. „Die offizielle Begründung lautet, dass in bestimmten Ländern die Menschen tatsächlich durch ein Merkmal zu definieren sind, da die Gesellschaft so stark segmentiert ist, dass sich die Menschen in jeder wichtigen Sachfrage konsequent ein und derselben Gruppe anschließen (...) Dieses System erkennt die Macht der Gruppenidentität und der Gruppenbindung an, obgleich politische Parteien in den Wahlen auf einer breiten Grundlage kandidieren und die Gruppen nicht zum Ersatz für die Politik an sich werden“ (Phillips 1995: 246).

In diesem Zusammenhang argumentiert Phillips deshalb: „Es wäre ein brauchbarer Grundsatz, dass gewisse Mechanismen zur Sicherung einer verhältnismä- 
Bigen Repräsentation einer Gruppe vorhanden sein sollten, sobald ein bestimmtes Merkmal bedeutsam geworden ist (d.h. entscheidenden Einfluss auf das Wohlergehen der davon betroffenen Menschen hat). Hat das Merkmal seine entscheidende Bedeutung verloren, sollten auch diese Mechanismen außer Kraft treten. Denkbare Verfahren wären dabei etwa aktive Förderungsmaßnahmen und Quotenregelungen seitens der politischen Parteien; in akuten Fällen könnten sie auch auf Regierungsebene wirksam werden und proportional zum Anteil an der Gesamtwählerschaft Ämter garantieren" (Phillips 1995: 248).

Jedoch sollte jedes System, das den Anspruch erhebt, demokratisch zu sein, auch garantieren, dass seine Repräsentantinnen und Repräsentanten, die die ethnische und geschlechtsspezifische Zusammensetzung der Bevölkerung widerspiegeln gleichwohl „nicht als „Vertreter" ihrer ethnischen Gruppe oder ihres Geschlechts betrachtet werden“, so könnte es „äußerst undemokratisch sein, wenn weibliche Abgeordnete ausschließlich oder in erster Linie als Sprecherinnen für Frauen gelten, vor allem ohne wirksame Verfahren zur Feststellung der politischen „Wählerschaft“ (Phillips 1995: 250). Es wäre viel zu restriktiv die WählerInnenschaft und die Gewählte nur durch eine Identität bestimmt zu sehen, vor allem wenn diese keine besondere Überzeugung beinhaltet. „Die Feministinnen haben zweifellos zu Recht verlangt, die Menschen sollten ihre Geschlechtsidentität nicht vor der Tür lassen müssen, wenn sie die politische Bühne betreten. Sie sollten freilich auch nicht genötigt sein, sich selbst anhand eines einzigen Kriteriums - in diesem Falle des Geschlechtes - zu definieren" (ebd.: 250f).

Hierbei handelt es sich nur um ein Spiegelmodell der Repräsentation, bei dem die RepräsentantInnen den Repräsentierten möglichst ähnlich sein müssen, Frauen also nur von Frauen repräsentiert werden können (vgl. Pitkin 1972: 80f). Dieses Modell birgt aber die Gefahr eines kruden Biologismus und einer identitären Vorstellung von Frausein. Vielmehr umfasst Repräsentation auch eine Handlungsdimension, die bedeutet, repräsentieren heißt nicht nur widerspiegeln, sondern für jemanden handeln. Auf der Grundlage relativer individueller Autonomie und eines Vertrauensverhältnisses zwischen Repräsentierten und Repräsentierenden wird Repräsentation als ein kommunikativer Prozess, in dem Differenzen ausgehandelt werden können, begriffen.

Anne Phillips kommt deshalb zum Ergebnis, dass das Prinzip der Gruppenrepräsentation dem Problem von „Demokratie und Differenz“ zwar beser begegnen könne als repräsentative Institutionen, dass es das Repräsentationsproblem aber keineswegs zufrieden stellend löst (vgl. Phillips 1993: 14; Phillips 1994: 106). Sie schlägt vor, sich von der Vorstellung einer homogenen Einheit, die es zu repräsentieren gelte, zu verabschieden (vgl. Phillips 1993: 4). Sie zeichnet also eine Vision von Demokratie durch Differenz, eine Politik, die die Partikularität von Gruppenidentitäten weder verleugnet noch vor ihr zurückschreckt 
(vgl. ebd.: 5). Ihre Vorstellung von Demokratie zielt auf eine Maximierung der Partizipation von Bürgerinnen und Bürgern ab und verlangt von den Menschen, sich der Demokratie zu verpflichten und miteinander in Diskurs zu treten. Das erfordert gleiche Partizipationschancen und einen direkteren Kontakt zwischen den Menschen. Vor allem aber müssen Differenzen auf einer öffentlichen Ebene artikuliert und in einer öffentlichen Debatte überprüft und gegebenenfalls revidiert werden (vgl. Phillips 1996: 143). So gilt es, gewissermaßen die Spannung zwischen einer Identitätspolitik, die möglicherweise ihre eigenen AusschlieBungsmechanismen produziert, und den Ausschluss von Frauen beispielsweise durch das Repräsentationsprinzip auszuhalten und ihn immer wieder kommunikativ aufzulösen. Phillips versucht, diese Spannung mit ihrem Konzept einer „Politik der Präsenz", die den Anspruch hat, weder separatistisch noch essentialistisch zu sein, auf Dauer zu stellen (vgl. ebd.: 142). „A politics of ideas is Phillips's term for a politics that focuses on policies and a representation that focuses on people's beliefs and interests. Fair representation is (...) realized in the ongoing responsiveness of representatives to those they are representing. The accountability of representatives to their electorate is therefore paramount. As long as they are responsive, it matters little who the representatives are (...). A politics of presence, on the other hand, is Phillips's term for a politics that focuses on the messengers themselves, and a representation that concentrates on people's identities. Fair representation (...) requires that the overly cerebral concentration on beliefs and interests be extended to recognise the normative and political significance of the identity of the representatives" (Squires 1999: 209).

Pluralität und Differenz sind in der liberalen Theorie nur auf der Ebene der Ideen, Meinungen und Präferenzen denkbar (,politics of ideas"), aber alle Differenzen, die aus unterschiedlichen Erfahrungen herrühren (,politics of presence“) sind nicht konzeptualisierbar und repräsentierbar und werden mithin ausgeschlossen (vgl. Phillips 1996: 140). „When the politics of ideas is taken in isolation from the politics of ideas, it does not deal adequately with the experiences of those social groups who by virtue of their race or ethnicity or religion or gender have felt themselves excluded from the democratic process" (Phillips 2006: 173). Politischer Exklusion qua Repräsentation könne deshalb begegnet werden, wenn „Ideen“ und „Erfahrung“ nicht separiert werden (vgl. Phillips 1996: 141). Die Politik der Präsenz repräsentiert nicht nur Interessen und Ideen, sondern Menschen. Die Verbindung und nicht die Opposition dieser beiden Politiken ist für Phillips die Möglichkeit eines neuen faireren Repräsentationssystems.

Zusammenfassend soll nach Phillips eine komplexe und schwierige Politik der Differenz betrieben und außerdem ein Impuls hin zu einer aktiveren sowie verpflichteteren Demokratie gesetzt werden, die sich aber keineswegs als Alternative zur Abhaltung von Wahlen versteht (vgl. Phillips 1993: 118f). „Wir müssen eine politische Sprache finden, die Heterogenität und Differenz anerkennt, ohne 
zugleich vor einem Reduktionismus zu kapitulieren, der jeden von uns nur durch einen einzigen Aspekt definiert" (Phillips 1995: 270). Für Phillips ist das Argument für eine gleiche Partizipation aller Bürgerinnen und Bürger unanfechtbar. Diese ist eine notwendige, aber nicht ausreichende Bedingung (vgl. Phillips 1996: 149). Sie besteht des Weiteren darauf, dass politische Ungleichheiten zwischen den unterschiedlichen Gruppierungen in unserer Gesellschaft stärker als bisher beachtet werden - zumindest insofern, als es notwendig ist, sich damit auseinanderzusetzen, dass in unserer vermeintlich gemeinsamen politischen Welt Exklusionen und Marginalisierungen existieren. Diese Auseinandersetzung muss in einer Art und Weise passieren, die Dialoge ermöglicht und sie nicht zum Schweigen bringt, und die nicht dazu führt, dass Menschen aus ihrer speziellen Subgruppen-Perspektive argumentieren müssen. Die Möglichkeit, solch einen Dialog zu erreichen, hängt grundlegend von den Idealen der Partizipation, Diskussion und Debatte ab. Wichtig ist jedoch, dass man nicht in folgende beiden Extreme abdriftet: in eine unegalitäre Demokratie, die sich allen Mechanismen zum Umgang mit Gruppenunterschieden und Gruppenexklusion verschlieBt, oder in eine fragmentierte Demokratie, die Menschen in ihren unterschiedlichen und möglicherweise verfeindeten Gruppen einschließt (vgl. Phillips 1993: $136 f)$.

\subsubsection{Funktionale bzw. Gruppenrepräsentation: die Repräsentation der Interessen und Bedürfnisse von Frauen im Politikprozess}

Während Phillips vorschlägt unter Repräsentation zunächst nur die Erhöhung des Frauenanteils in politischen Gremien - die Präsenz und Sichtbarkeit von Frauen (quantitative Repräsentation) - zu verstehen, befürwortet Iris Marion Young eher eine Principal-Agent-Repräsentation von Frauen - basierend auf Gruppen und nicht auf Individuen (vgl. Squires 1999: 212) - und entwickelt die Idee einer Gruppenrepräsentation (qualitative Repräsentation): „One important way to promote greater inclusion of members of under-represented social groups is through political and associational institutions designed specifically to increase the representation of women, working-class people, racial or ethnic minorities, disadvantaged castes, and so on. Techniques of quotas in electoral lists, proportional representation, reserved seats, the drawing of boundaries for electoral jurisdictations, [can be] proposed" (Young 2000: 141).

Young sieht die Lösung des „Paradox der Demokratie, wodurch soziale Macht einige Staatsbürger gleicher macht als andere und die Gleichheit des Staatsbürgerstatus manche Menschen zu mächtigeren Staatsbürgern macht" darin, ,institutionalisiertere Wege zur ausdrücklichen Anerkennung und Repräsentation unterdrückter Gruppen zu schaffen" (Young: 1993: 279). Ausgangspunkt hierbei sind nicht Interessengruppen, sondern soziale Gruppen: „A social group is a collective of persons differentiated from at least one other group by cultural forms, 
practices, or way of life" (Young 1999: 43). Eine soziale Gruppe beinhaltet ihrer Auffassung nach eine „Affinität mit anderen Personen, über die sie sich mit dem jeweils anderen identifizieren und vermittels derer andere Menschen sie identifizieren“ (Young: 1993: 279). „Als Produkte sozialer Verhältnisse sind Gruppen fließende Gebilde, sie entstehen und können auch wieder zerfallen (...). Die Identität einer Gruppe wird vielleicht erst unter ganz bestimmten Umständen überhaupt auffällig, dann nämlich, wenn dies mit anderen Gruppen interagiert. Außerdem haben die meisten Menschen in den modernen Gesellschaften mehrfache Gruppenidentifikationen. Deshalb sind Gruppen an sich keine eigenständigen Einheiten. Jede Gruppe weist durch sie hindurchgehende Gruppendifferenzen auf" (Young 1993: 281f).

$\mathrm{Zu}$ argumentieren, dass zwischen sozialen Gruppen Unterschiede bestehen, bedeutet nicht, dass keine überlappende Erfahrung zwischen den Gruppen bestehen beziehungsweise dass zwei Gruppen nichts gemeinsam haben: „Different groups are always similar in some respects, and always potentially share some attributes, experiences, and goals" (Young 1990: 171). Eine Gruppe ist laut Young dann unterdrückt, wenn ,auf alle oder auf einen großen Anteil ihrer Mitglieder einer oder mehrere der folgenden Sachverhalte zutreffen" (Young 1993: 282):

- Ausbeutung: Der Nutzen ihrer Energie oder Arbeit geht auf andere über, ohne dass die anderen ihnen nützen: „The injustice of exploitation consists in social processes that bring about a transfer of energies from one group to another to produce unequal distribution, and the way in which social institutions enable a few to accumulate while they constrain many more" (Young 1990:53).

- Marginalisierung: Sie sind von Partizipation an wichtigen sozialen Tätigkeiten ausgeschlossen, ,marginalization (...) blocks the opportunity to exercise capacities in socially defined and recognized ways" (Young 1990: 54).

- Machtlosigkeit: Sie leben und arbeiten unter Autorität von andern, verfügen kaum über Autonomie und haben selbst keine Autorität über andere, ,the powerless (...) exercise little creativity or judgement in their work, have no technical expertise or authority, express themselves awkwardly, especially in public or bureaucratic setting, and do not command respect" (Young 1990: 54f).

- Kulturimperialismus: Sie werden als Gruppe stereotypisiert „und gleichzeitig bleiben ihre Erfahrungen und ihre Situation in der Gesellschaft im allgemeinen unbemerkt, zudem haben sie wenig Gelegenheit, ihrer Erfahrung und ihrer Sichtweise von sozialen Geschehnissen Ausdruck zu ver leihen und finden kaum Gehör wenn sie es tun" (Young 1993: 282). 
„Those living under cultural imperialism find themselves defined from the outside, positioned, place, by a network of dominant meanings they experience as arising from elsewhere, from those with whom they do not identify and who do not identify with them"(Young 1990: 59).

- Gewalt: Sie sind willkürlicher und systematischer Gewalt und Schikane aufgrund von Gruppenhass oder -angst ausgesetzt.

Politische Gleichheit kann nur realisiert werden, wenn es Mechanismen der Repräsentation von Gruppenunterschieden gibt, eine demokratische Theorie kann nicht unter der Voraussetzung einer undifferenzierten Menschheit entwickelt werden, sondern muss vielmehr dem Vorhandensein von Gruppendifferenzen und der Unterdrückung und Benachteiligung von Gruppen Rechnung tragen und der Input marginalisierter Gruppen im Politikprozess gestärkt wird (vgl. Young 1993: 283). „Commitment to political equality entails that democratic institutions and practices take measures explicitly to include the representation of social groups whose perspectives would like be excluded from expression in discussions without those measures" (Young 2000: 148). In einer nach Gruppen differenzierten Gesellschaft impliziert Gerechtigkeit soziale Gleichheit von Gruppen und gegenseitige Anerkennung der Gruppenunterschiede. Die Anerkennung gruppenspezifischer Bedürfnisse und das Einführen einer Gruppenrepräsentation tragen zu einer solchen sozialen Gleichheit bei und führen wiederum zu mehr Anerkennung der unterdrückten Gruppen (vgl. Young 1990: 191).

Demgemäß sollten in einer Demokratie Mechanismen bereitgestellt werden zur „wirksamen Vertretung und Anerkennung der unterschiedlichen Stimmen und Perspektiven, die denjenigen Gruppen gehören, die konstitutive Bestandteile“ dieser Demokratie sind ,und die in ihr unterdrückt und benachteiligt sind. Eine solche Gruppenvertretung impliziert institutionelle Mechanismen und öffentliche Ressourcen zur Unterstützung“" (Young 1993 283) von:

- der politischen Selbstorganisation der Gruppenmitglieder, damit diese einen Sinn für eine kollektive Ermächtigung ebenso wie ein reflexives Verständnis ihrer kollektiven Erfahrung und ihres kollektiven Interesses im Kontext der Gesellschaft bekommen

- dem Erstellen von Analysen der Gruppe wie sich gesellschaftspolitische Maßnahmen auf sie auswirken, sowie dem Hervorbringen eigener politischer Vorschläge in institutionellen Zusammenhängen, wo die Entscheidungsträgerinnen und -träger dazu verpflichtet sind diese Perspektiven in ihre Überlegungen einzubeziehen

- dem Vetorecht hinsichtlich bestimmter politischer Maßnahmen, die die Gruppe direkt und in besonderer Weise betreffen (vgl. Young 1990: 184, Young 1993: 283). 
Die Gruppenmitglieder sollen in demokratischen Foren zusammentreffen um Fragen zu diskutieren, Vorschläge zu formulieren und Stellungnahmen zu erarbeiten. Hierfür sollte das ,öffentliche Leben und die Prozesse der Entscheidungsfindung so umgestaltet werden, dass alle Staatsbürger[Innen] erheblich mehr Gelegenheit zur Teilnahme and der Diskussion und Entscheidungsfindung haben" (Young 1993: 290). Dementsprechend sollten alle Staatsbürgerinnen und -bürger einen Zugang zu Nachbarschaft- und Gebietsversammlungen haben und dort an Diskussionen und Entscheidungsfindungen beteiligt sein. „In einem solchen stärker partizipatorischen demokratischen Schema hätten dann auch die Mitglieder unterdrückter Gruppen ihre Gruppenversammlungen, die dann Gruppenvertreter delegieren würden" (ebd.).

Für Young ist eine Gruppenrepräsentation das beste Mittel um gerechte „Ergebnisse in demokratische Prozesse der Entscheidungsfindung herbeizuführen" (Young 1993: 285), ,in Verhältnissen, die von sozialer Unterdrückung und Beherrschung geprägt sind, ist die Gruppenvertretung die beste Institutionalisierung von Fairness" (ebd.: 286). Denn die Existenz sozialer Gruppen impliziert „verschiedene, wenn auch nicht unbedingt zwangsläufig nicht vergleichbare Vergangenheiten, Erfahrungen und Perspektiven auf das soziale Leben, und sie impliziert, dass die Menschen die Erfahrungen anderer Gruppen nicht vollends verstehen können. Niemand kann beanspruchen im Allgemeininteresse zu sprechen, weil keine der Gruppen für die andere sprechen kann, und ganz gewiss kann keine Gruppe für alle sprechen. Wenn man erreichen will, dass alle Gruppenerfahrungen und sozialen Perspektiven ausgesprochen, angehört und in Rechnung gestellt werden, ist darum der einzige Weg derjenige, sie jeweils einzeln in der Öffentlichkeit repräsentiert zu haben." (Young 1993: 285). Gruppenrepräsentation ist des Weiteren das „beste Gegenmittel gegen ein sich selbst täuschende Eigeninteresse das als ein unparteiliches oder Allgemeininteresse getarnt ist" (ebd.: 286), denn mit Hilfe der Gruppenvertretung bekommen diejenigen die sonst nicht gehört werden die Möglichkeit ihre Interessen und Bedürfnisse darzulegen.

Die Vertretung bestimmter Gruppen ist immer dann ,angezeigt, wenn die Geschichte und die soziale Situation einer Gruppe eine besondere Perspektive auf strittige Fragen mit sich bringt, wen die Interessen der Mitglieder besonders betroffen sind und wenn ihre Wahrnehmungen und Interessen ohne eine solche Vertretung wenig Aussicht haben, Ausdruck zu finden“"(Young 1993: 289). 


\subsubsection{Repräsentation und Anerkennung von Unterschieden zwischen Frauen sowie Berücksichtigung von Differenzen aufgrund von Alter, Klasse, Ethnie, Religion, Sexualität}

Die Kategorie ,Frauen' verstanden als ein universalistisches Konzept wird mittlerweile zunehmend hinterfragt und verworfen. Denn „,Frauen' sind nicht homogen und sprechen nicht mit einer Stimme" (Phillips 1995: 128).

Diese Herausforderung verzeichnet zwei Ursprünge: zum einen den theoretischen Fortschritt des Poststrukturalismus und zum anderen die Forderungen von schwarzen und anderen Frauengruppen, deren Identitäten und Interessen ignoriert, marginalisiert und unter die Kategorie Frauen subsumiert wurden. Ähnlich wie die Vorstellung eines abstrakten Individuums der traditionellen politischen Theorie von einem spezifischen hegemonialen Männlichkeitsmuster geprägt wurde, dominierte das Frauenbild von einflussreichen Frauengruppen über lange Zeit feministische Theorie und Politik (vgl. Lister 1997: 16).

Demgemäß besteht die Notwendigkeit, auch die Kategorie Frauen zu problematisieren, um eine Anerkennung der Differenzen zwischen Frauen, ebenso wie der Art und Weise, wie diese Differenzen die ökonomischen, sozialen und politischen Beziehungen zwischen Frauen, aber auch zwischen Frauen und Männern und Frauen und dem Staat gestalten, zu erwirken. Hierbei ist zu berücksichtigen, dass die Gefahr besteht, wenn ,Frauen' einfach dekonstruiert werden und gleichsam in Fragmenten zurückgelassen werden, es keine Frauen als Staatsbürgerinnen oder als kollektiv Handelnde mehr gibt: „The fact that the category ,woman' is not unitary does not render it meaning-less" (ebd.). Daher ist ein Projekt des Engenderings von Staatsbürgerschaft (vgl. Kapitel 4.2.3) „,not invalidated, but it has to be conceived of as part of a wider project of differentiating citizenship“ (Lister 1997: 17).

Für die Entwicklung einer „glaubwürdigen Version“ (Fraser 2001: 272) einer feministischen Demokratie hat in den letzten Jahrzehnten folgende These an Bedeutung gewonnen: Es muss eine neue „Debatte um Gleichheit/Differenz" geführt werden, die ,an vielfältigen, sich überschneidenden Differenzen orientiert ist" (ebd.: 273).

Hierbei darf nicht die Geschlechterdifferenz einziger Schwerpunkt sein, sondern es ist eine Verschiebung zu „Differenzen unter Frauen und den vielfältigen, sich überschneidenden Differenzen“ (ebd.) erforderlich. „Wir sollten vielmehr eine alternative Version entwickeln, die es uns gestattet, normative Urteile über den Wert unterschiedlicher Differenzen abzugeben, indem wir das Verhältnis dieser Differenzen zur Ungleichheit untersuchen. Alles in allem müssen wir einen Weg finden, den Kampf für einen antiessentialistischen Multikulturalismus mit dem Kampf für soziale Gleichheit zusammenzuschließen“ (ebd.). Wir müssen also „eine politische Sprache finden, die Heterogenität und Differenz anerkennt, oh- 
ne zugleich vor einem Reduktionismus zu kapitulieren, der jeden von uns nur durch einen einzigen Aspekt definiert" (Phillips 1995: 270). Außerdem ist es notwendig, eine komplexe und schwierige Politik der Differenz zu betreiben (vgl. Phillips 1993: 118) und einen Impuls hin zu einer aktiveren und verpflichteteren Demokratie zu setzen, ohne dabei auf herkömmliche demokratische Mittel, wie beispielsweise Wahlen, zu verzichten (vgl. ebd.: 119).

\subsubsection{Political Leadership und Empowerment - Entscheidungs- und Definitionsmacht für Frauen}

Nach Shirin M. Rai betrifft der Begriff ,Political Leadership' sowohl die politische Partizipation (vgl. Kapitel 4.2.2) als auch die politische Repräsentation (vgl. Kapitel 4.3.2 und 4.3.3) und bezeichnet, ,the processes by which individual political actors can be influential in shaping political agendas, taking the lead in articulating these and participating in their translation into policy“ (Rai 2005: 23). Political Leadership ist in beiden Bereichen ebenso wie auf den verschiedenen Ebenen dieser beiden Bereiche notwendig, „to ensure that women and men have equal access to both the processes of decision-making and benefit equally from the outcomes of those processes" (ebd.: 27). Political Leadership ist relational, denn es erzeugt eine Verbindung von Menschen zueinander - innerhalb und außerhalb von zivilgesellschaftlichen Bewegungen, politischen Institutionen oder Organisationen und benötigt daher verschiedene Fähigkeiten der Kommunikation, des Netzwerkens und des Führens in verschiedenen Kontexten und Weisen. Es ist ein Prozess durch den eine Person andere beeinflusst ein Ziel zu erreichen (vgl. Kapitel 4.3.1) und damit Organisationen in bestimmte Richtungen dirigiert. „It involves the combination of imagination in inventing institutional options and skills in brokering the interest of numerous actors to line up support for such options" (Kardam/Acuner 2003: 112). Ein solches Konzept unterscheidet sich grundlegend von einem Konzept der Macht beziehungsweise Gewalt über andere. Es basiert auf Autorität, die sowohl institutionell - kraft der Position die eine Person innehat - oder auch normativ - aufgrund der Fähigkeiten einer Person zu führen - bedingt sein kann. Die notwendigen Qualitäten sind demgemäß Vertrauen, Vorstellungskraft, Kreativität, strategisches Denken und Innovationsfähigkeit genauso wie eine demokratische Praktik des Zuhörens sowie die Fähigkeit zu verhandeln, Allianzen zu bilden und andere zu inspirieren. Diese Qualitäten müssen von Personen gelernt werden. Dieser Fokus auf das Lernen ermöglicht eine Transformation der traditionell männlichen Vorstellungen von Political Leadership (vgl. Rai 2005: 23f).

Traditionell sind die Führungspositionen in den meisten staatlichen ebenso wie zivilgesellschaftlichen Entscheidungsgremien noch immer in den Händen der Männer: Politik „the world over appear[s] hostile to women's engagement in decision-making, especially at top leadership levels"; ,though women participate, 
they have often found themselves relegated to lower levels in hierarchies" (Cornwall/Goetz 2005: 788). Und ,where women have become leaders, they have had to negotiate a heavily patriarchal domain, which has meant that they have often been reluctant to take up the cause of women's rights" (Rai 2005: 24). „For many women, available spaces for political learning are patriarchal and traditional institutions (family, community), often apolitical women's associations or informal association that either assign women to the tea-making brigade (women's wings of parties) or make women's ascent to leadership positions contingent on patronage from a top male leader. In the first case, women receive little training for democratic participation. In the second, there is often too weak a foundation to back political interests with constituency support and resources for formal politics. In the third, women leaders are cut off from a constituency base that might enable them to question party leadership and bring women's interest on the party agendas" (Cornwall/Goetz 2005: 795).

Die Voraussetzung für das Übernehmen von politischen Leadership-Rollen durch Frauen ist in diesem Zusammenhang zunächst einmal Information, denn die Partizipation von Frauen in der Politik ist oft auf das Fehlen von Informationen zu spezifischen Themen zurückzuführen. Der Zugang zu Informationen wird zum einem vom Bildungsniveau und zum anderen von institutionellen Verfahren beeinflusst. Daher sind Bildung und Schulungen die Schlüsselressourcen um Frauen Führungspositionen zu ermöglichen: „Training also allows women to come together to discuss issues. The space made available for training becomes a political space of interaction, support and networking" (Rai 2005: 25).

Ebenso wie Partizipation und Repräsentation wird Political Leadership auf verschiedenen Ebenen der Mobilisierung und Organisation ausgeübt. Hierbei ist ,women's networking (...) an important way of consolidating leadership qualities. Networks can provide an agenda-setting function by 'linking up' women's knowledge and expertise bases as well as organizations and individuals. Sharing experience of initiating change, of institutional sexism, of strategies that work or do not work in dealing with difference among women, and of sources of funding, of information can all help women in political life to survive and perform to the best of their ability" (ebd.).

\subsubsection{Responsivität politischer Institutionen}

Der formelle und informelle Maskulinismus politischer Entscheidungssysteme ist „Ursache für die geringe Responsivität politischer Institutionen gegenüber den Belangen von Frauen. Frauenfreundlichkeit oder Frauenfeindlichkeit von Politiken gelten nicht als Gütekriterien für politische Entscheidungen" (Sauer 2001: 174). Daher fordern feministische Demokratietheorien neben der Erhöhung der Einbindung von Frauen in die Politik (vgl. Kapitel 4.2.2 und 4.3.2 sowie 4.3.3) auch die verstärkte frauenpolitische Responsivität. Dies bedeutet eine 
gezielte Bearbeitung von Frauenthemen, eine Verantwortlichkeit von Regierungen und politischen Institutionen für Frauen beziehungsweise Geschlechterfragen und dass frauenpolitische Anregungen zu hörbaren Argumenten im Staatsdiskurs werden. Gerade in der Praxis stehen wir oft vor der Entscheidung, „ob wir eine Frau unterstützen, weil sie eine Frau ist, oder einem Mann unsere Stimme geben, der unseren Überzeugungen näher zu stehen scheint." (Phillips 1995: 115). Hierbei geht es gar nicht um „die extremeren Formen des Dilemmas, denn zu glauben, Margaret Thatcher als Premierministerin sei für Frauen besser als ein Mann, der mehr Kindertagesstätten oder einen höheren Mindestlohn fordert, wäre wildgewordener methodologischer Individualismus. Aber auch innerhalb einer Partei kann sich dieses Problem stellen - selbst dann, wenn sich die Frau als Sprecherin der Frauen präsentiert. Wollen wir, dass die Interessen der Frauen von Frauen vertreten werden oder dass die von uns unterstützte Partei für ihre Bedürfnisse und Anliegen eintritt?"“(Phillips 1995: 115)

Es mag jedenfalls eine notwendige aber keinesfalls hinreichende Bedingung sein, dass mehr Frauen gewählt werden, denn ,die Frage ob Frauen als eine durch gemeinsame Interessen definierte Gruppe gelten können, deren Interessen dann ihre Vertretung finden müsste" (Phillips 1995: 116) ist damit noch nicht geklärt. Durch die Forderung nach mehr Repräsentantinnen kann weder theoretisch noch praktisch gewährleistet werden, „dass Frauen als Frauen repräsentiert sind“ (ebd.: 129) wird. Eine gleiche Partizipation von Frauen und Männern ist zwar das Ziel, dennoch erwirkt eine gleiche Partizipation nicht zwangsweise eine gleiche Repräsentation, denn nur weil Frauen die Hälfte aller Sitze in den entscheidungsrelevanten Gremien besetzten, bedeutet dies nicht automatisch eine frauenfreundliche Politik (vgl. Phillips 1993: 135).

Beispielsweise haben Lael Keiser et al in ihrer Untersuchung über die Bedingungen, dass Verwaltungsmitarbeiterinnen als Frauen im Interesse von Frauen handeln, Folgendes herausgearbeitet: Zunächst müssen die Bürokratinnen eine "discretion in how they carry out their jobs" haben und zweitens muss es sich um politische Bereiche handeln, die ,salient to demographic characteristics such as gender" sind (Kreiser et al o.J: 10). Grundsätzlich sehen sie dementsprechend folgende sieben institutionelle beziehungsweise kontextuelle Faktoren dafür ausschlaggebend, dass Frauen die Interessen von Frauen repräsentieren:

- Verfügungsfreiheit beziehungsweise Machtbefugnis um Entscheidungen und Ergebnisse beeinflussen zu können (,discretion”): dort wo Entscheidungen bei vermeintlichen Sachzwängen und Regeln diktiert werden, bestehen kaum Möglichkeiten die Interessen bestimmter Gruppen zu vertreten und Outputs so zu gestalten, dass sie bestimmten Gruppen dienen (vgl. ebd.)

- Geschlechtsspezifische Aufgabenbereiche und Sachverhalte (,gendering of a given policy issue"): eine aktive Repräsentation von Frauen gibt es 
vor allem in den Bereichen in denen Frauen- und Geschlechterthemen bearbeitet werden oder die im politischen Prozess als frauenspezifischen Fragen definiert wurden. Außerdem ist es einer Repräsentation der Interessen von Frauen zuträglich, wenn die Repräsentantinnen die gleichen demographischen Merkmale teilen und damit auch ähnliche Lebenserfahrungen haben wie die Repräsentierten (vgl. ebd.: 11f).

- Einsatz beziehungsweise Auftrag einer bestimmten Gruppe zu assistieren (,advocacy mission“): Auch wenn RepräsentantInnen nicht die gleichen demographischen Merkmale teilen wie die zu Repräsentierenden, so kann eine aktive Repräsentation auch dadurch erwirkt werden, dass sie den Auftrag haben die Interessen einer Gruppe zu vertreten beziehungsweise als FürsprecherInnen diese Gruppe zu fungieren (vgl. ebd.: 12f).

- Flache Hierarchien: desto hierarchischer und zentralisierter Organisationen sind, desto weniger aktive Repräsentation ist möglich, da Beziehungen entpersönlicht werden und die Mitglieder der Organisation sich weit schwerer mit Gruppen außerhalb der Organisation identifizieren können. „According to this line of thinking, hierarchical organizations cannot be feminist organizations" (ebd.: 13).

- Mehr Frauen in Führungspositionen (,stratification”), denn diese erhöhen die Wahrscheinlichkeit einer aktiven Repräsentation (vgl. ebd.: 14).

- Kritische Masse an Frauen (,critical mass“): je mehr kritische und feministische Frauen in einer Organisation sind, desto eher wird eine aktive Repräsentation möglich (vgl. ebd.).

- Zusammenarbeit mit und Einbindung von WissenschafterInnen, „because women may be more disposed toward engaging in active representation for women due to shared experience (...) greater professionalization will facilitate the translation of passive representation into active representation" (ebd.)

Phillips fasst dementsprechend zusammen: „Eine Demokratie braucht vielleicht die Gleichstellungspolitik vor der Gleichheit der Repräsentation“ (Phillips 1995: 130).

\subsubsection{Transparenz von Politikprozessen}

Eine feministische Demokratietheorie braucht heute laut Barbara Holland-Cunz ,angesichts der komplexen widersprüchlichen, heterogenen, zunehmend undurchsichtigen und hoch dynamischen gesellschaftlichen Prozesse (...) v. a. Transparenz: Durchsichtigkeit und Zugänglichkeit der Entscheidungswege. Zeitgenössische Demokratietheorie braucht eine dazu ,passende“ strukturelle Schlichtheit, die die politischen Herausforderungen angemessen in transparente 
Institutionenarrangements übersetzt. Die Schlichtheit der Theorie müsste hier die gewünschte Transparenz spiegeln" (Holland-Cunz 2003: 245). Wobei hiermit „die gleichsam komplexe Schlichtheit zugänglicher, verständlicher, vermittelbarer Sachentscheidungen und entsprechender Entscheidungswege und -orte" gemeint ist.

Die feministische Demokratietheorie sollte „gleichsam auf die Schönheit der Schlichtheit und Transparenz setzen“ (ebd.: 245). Demokratie braucht „theoretisch wie praktisch, vor allem Verstehbarkeit und Transparenz in den Vorschlagskonstruktionen, Durchsichtigkeit und Zugänglichkeit der politischen Entscheidungsverfahren und normative Klarheit in den Grundlagen. Demokratietheorie benötigt eine strukturelle Schlichtheit, die die Herausforderungen angemessen transparent in Demokratiepolitik übersetzt" (Holland-Cunz 2001: 74).

\subsubsection{Kontrolle - Rechenschaftspflicht - Accountability}

Mit einer Forderung nach mehr Repräsentantinnen kann, wie in Kapitel 4.3.2 herausgearbeitet, nicht garantiert werden, dass Frauen als Frauen repräsentiert werden, ,there is no straightforward equation between getting women into political office and the pursuit of policies of gender equality by these same women (...) women in office do not necessarily defend a feminist position on policies" (Cornwall/Goetz 2005: 784). Des Weiteren kann damit auch nicht das Problem der „Machthierarchie“ gelöst werden. Daher ist „zu versuchen die Führer[Innen] rechenschaftspflichtig gegenüber den Geführten zu machen“" (Phillips 1995: 218). Ein/e legitimierte/r RepräsentantIn muss gegenüber denjenigen die sie/er repräsentiert rechenschaftspflichtig sein, „otherwise the agent who claims to represent is simply acting on his or her way (Young 2000: 128). Gerade im Kontext von Repräsentation (vgl. Kapitel 4.3.2 und 4.3.3) und Beeinflussung des Outcomes von Politiken (vgl. Kapitel 4.4.1) besteht die Notwendigkeit Rechenschaftspflicht zu berücksichtigen (vgl. Rai 2003: 266).

Rechenschaftspflicht oder Accountability kann als Anforderung an ,representatives and representative organizations to answer for the exercise of their powers, listen to and act upon criticism or requirements made of them where appropriate and accept (some) responsibility for failure, incompetence, or deceit" (Rai 2005: 24) definiert werden. Repräsentierende sind verantwortlich für ihre Entscheidungen und Mandate und sollen angehalten sein, den von ihnen Repräsentierten zu zuhören und deren Kritik, Anforderungen und Forderungen in ihre Arbeit aufzunehmen. Denn the „demands for transparent, accountable procedures and protocols to engage in processes (...) are central to democratic practice" (Taylor 2007: 31). Repräsentation ist erst dann demokratisch, wenn „leaders are both responsive and accountable to the people. Accountability is about positive and negative sanctions, and is a defining characteristic of democracy. Responsiveness requires leaders with powers - the discretionary power to trans- 
late needs and aspirations into policy and policy into practice. In short, to be democratic institutions must be representative: accountable to the people and empowered to respond (Ribot 2007: 45).

Rechenschaftspflicht kann - so Shirin Rai - auf verschiedenen Ebenen diskutiert werden. Sie schlägt folgende drei unterschiedliche Ebenen vor:

- Die normative Diskussion unterstreicht, dass Frauen ,a different style of politics to the public sphere" bringen und Rechenschaftspflicht in diesem Zusammenhang ,in terms of openness to different standpoints and to varied strategic and practical interests" (Rai 2003: 266) zu betrachten ist. Denn Rechenschaftspflicht deren Fokus auf der Verantwortung der Repräsentierenden liegt, kann Frauenbewegungen die Kommunikation zu den Regierenden ermöglichen ebenso wie Möglichkeiten eröffnen, neue Formen von Politik und Demokratie zu diskutieren.

- Pragmatische Gründe für eine Rechenschaftspflicht sind, dass die Repräsentierenden ohne sie ihre Unterstützungsbasis beispielsweise in FrauenNGOs oder in der Frauenbewegung verlieren könnten (vgl. Rai 2003: 266f).

- Effizienzargument: „The support of various groups increases the legitimacy" (Rai 2003: 267) ,which allows them to be more effective in agenda setting discussions as well as in securing support for special measures for enhancing women's presence in public life" (Rai 2005: 24).

Die Rechenschaftspflicht betrifft jedoch nicht nur offizielle politische Institutionen sondern auch ,the public life of independent civic association" (Young 2000: 123). Damit könnten Entscheidungsfindungsprozesse so gestaltet werden, dass sie ,inclusive, open and transparent, active and participative, respectful and accountable" sind, dass Entscheidungen auf ein Niveau „most appropriate by those most affected" gebracht werden können. Weiters soll damit gewährleistet werden dass alle das Recht auf und den Zugang zu den gleichen Informationen bekommen sowie dass ,the views of the most marginalized are as valid as those of others“ (O'Connell 2007: 14). „All existing representative democracies could be improved by additional procedures and fora through which citizen discuss with one another and with representatives their evaluation of policies representatives have supporter. Official means of accountability distinct from election campaigns can include civic review boards, implementations studies, and periodic official participatory hearings following the policy-making process. Public spheres of civil society can further accountability by means of independent questioning, praise, criticism, and judgement" (Young 2000: 132).

Während im Mainstream politikwissenschaftlicher Diskussionen vor allem im Zuge der Europäisierung von Politik Accountability vornehmlich im Sinne eines Output-orientierten Demokratiemodells verstanden wird, also eine aktive Parti- 
zipation von Bürgerinnen und Bürgern für demokratische Politikgestaltung weit weniger wichtig gilt als die Qualität und Zurechenbarkeit politischer Entscheidung, versteht die feministische Debatte unter den Stichworten Rechenschaftspflicht und Kontrolle von Politikprozessen zwar Ähnliches, diskutiert dies jedoch mit einer anderen demokratietheoretischen Bedeutung: In der feministischen Demokratiedebatte bedeutet Rechenschaftspflicht nicht den Ausschluss von Partizipation, sondern vielmehr verstärkte Kontroll- und Eingriffsmöglichkeiten in politische Entscheidungsprozesse.

\subsection{Output (K3)}

\subsubsection{Frauenfreundlicher Output von Politik: geschlechtergerechte Umver- teilung von Ressourcen (Geld und Macht)}

Ungerechtigkeit muss also auch als sozioökonomische Ungerechtigkeit verstanden werden, der mit Hilfe von Umverteilungsmaßnahmen gegengesteuert werden kann. Jedoch verfolgen eine Politik der Anerkennung und eine der Umverteilung offenbar häufig widersprüchliche Ziele. Umverteilung und Anerkennung werden in „zunehmendem Maße als Alternativen veranschlagt, die einander ausschließen" (Fraser 2003: 26). Während die Umverteilung laut Nancy Fraser dazu neigt die Gruppendifferenzierung zu fördern, ,ist die zweite bestrebt diese zu untergraben. Die zwei Anspruchsarten stehen folglich in einem Spannungsverhältnis zueinander, sie können sich beeinträchtigen oder sogar gegeneinander arbeiten" (Fraser 2001: 33). Hierin liegt das so genannte Umverteilungs-Anerkennungs-Dilemma: Menschen, die sowohl von kultureller Ungerechtigkeit als auch von ökonomischer Ungerechtigkeit betroffen sind, benötigen Anerkennung ebenso wie Umverteilung, dies bedeutet, sie müssen einerseits ihre Besonderheit geltend machen und andererseits diese gleichzeitig auch verleugnen. Klar ist aber, dass die Anerkennung von Geschlechterdifferenz sowie formalrechtliche Gleichstellung wie beispielsweise das aktive und passive Wahlrecht alleine ohne die Berücksichtigung von sozialen und ökonomischen Rahmenbedingungen kein hinreichendes Kriterium zur Erfüllung des demokratischen Anspruchs von politischer Gleichheit darstellen. Denn auch abgesehen von Geschlecht und "Rasse“ sind Disparitäten in der ökonomischen Ressourcenverteilung feststellbar, die uns - kombiniert mit einem ungleichen $\mathrm{Zu}$ gang zu Wissen, Information und polischen Fachkenntnissen - nicht nur sozial sondern auch politisch ungleich machen (vgl. Phillips 1993: 104f). „Soziale und ökonomische Privilegierung heißt unter anderem, dass die Gruppen, die das Privileg innehaben, sich so verhalten, als ob sie das Recht hätten zu sprechen und gehört zu werden, dass andere sie so behandeln, als ob sie jenes Recht hätten und dass sie über materielle, personelle und organisatorische Ressourcen ver- 
fügen, die sie in die Lage versetzen, in der Öffentlichkeit zu sprechen und gehört zu werden" (Young 1993: 284).

„Economic equality matters and its absence has serious political effects" (Phillips 1999: 98). Politische Gleichheit ist stets ein Spiegelbild ,gesellschaftlicher und wirtschaftlicher Gleichheit", daher werden Frauen und Männer im politischen Bereich nicht gleichberechtigt agieren können, ,solange sich Frauen in einer Position der Abhängigkeit von Männern befinden - und diese Position durch das Zusammenwirken sozialer, wirtschaftlicher und kultureller Kräfte so gefestigt scheint, dass kaum ein Ansatzpunkt für Veränderungen erkennbar wird" (Phillips 1995: 136).

Wie in Kapitel 4.2.5 dargestellt, erfordert Gerechtigkeit laut Nancy Fraser „heute sowohl Umverteilung als auch Anerkennung“ (Fraser 2001: 24). „Keine von beiden ist alleine ausreichend" (Fraser 2003: 17). Ungerechtigkeit kann analytisch als eine sozioökonomische Ungerechtigkeit, „die in den politisch-wirtschaftlichen Strukturen der Gesellschaft ihren Grund hat" (Fraser 2001: 27), verstanden werden. Beispiele hierfür sind Ausbeutung, wirtschaftliche Marginalisierung und Deprivation. Ökonomischen Ungerechtigkeit kann durch „eine wie auch immer geartete politisch-wirtschaftliche Umstrukturierung gegengesteuert“ werden, dies „kann in Form einer Einkommensumverteilung, einer Neuorganisation der Arbeitsteilung oder durch die Einführung demokratischer Beschlussfassung für Investitionen und die Veränderung anderer ökonomischer Grundstrukturen geschehen" (ebd.: 30). Die vielfältigen Maßnahmen werden unter dem Oberbegriff „Umverteilung“" zusammengefasst.

Vor diesem Hintergrund wird deutlich, dass Gender auch politisch-ökonomische Dimensionen aufweist, da es ein grundlegendes Strukturprinzip der politischen Ökonomie ist. Einerseits strukturiert Gender die Einteilung in bezahlte, produktive Arbeit und unbezahlte, reproduktive beziehungsweise häusliche Arbeit, wobei Frauen grundsätzlich die Verantwortung für letztere zugewiesen wird. Andererseits strukturiert Gender ,auch die Einteilung der entlohnten Arbeit in besser bezahlte, von Männern dominierte, herstellende und höherqualifizierte Berufe und niedriger entlohnte, von Frauen dominierte, ,pink-collar' und hauswirtschaftliche Berufe. Das Ergebnis ist eine politisch-ökonomische Struktur, die geschlechtsspezifische Formen der Ausbeutung, Marginalisierung und Deprivation erzeugt" (Fraser 2001: 40)

Geschlechterspezifische Ungleichheiten finden daher auch als verteilungsbezogene Ungerechtigkeiten ihren Ausdruck und verlangen demnach einen Ausgleich durch Umverteilung. Eine Beseitigung dieser Ungerechtigkeiten bedarf jedoch einer Veränderung sowohl der politischen Ökonomie als auch der Kultur. Dementsprechend müssen für die Verwirklichung von Gerechtigkeit alternative Konzepte von Umverteilung und Anerkennung entwickelt werden (vgl. Fraser 2001: 65). Wichtig ist, dass das Resultat eine Entschärfung des Umvertei- 
lungs-Anerkennungs-Dilemmas sein sollte, und zwar indem Ansätze gefunden werden, die in den Fällen, in denen gleichzeitig Umverteilungs- und Anerkennungsmaßnahmen verfolgt werden müssen, die Konflikte möglichst gering halten (vgl. ebd.: 63).

Auch für Carole Pateman ist eine Umverteilung von Ressourcen nötig um die politischen Grundlagen von Demokratie zu gewährleisten. Sie bezieht sich hierbei auf individuelle Freiheit verstanden als Selbstregierung beziehungsweise Autonomie. Um eine solche Autonomie zu gewährleisten, müssen Menschen mit Rechten ausgestatten werden und mit Institutionen interagieren, die ihre Selbstbestimmung fördern. Autonomie beinhaltet nicht nur die individuellen ökonomischen Möglichkeiten und die Möglichkeit an der kollektiven Selbstbestimmung teilzunehmen, sie umfasst auch die individuelle Unabhängigkeit (Autonomie). Letzteres wird in einem zu engen Verständnis von Demokratie, das meist auf kollektive (nationale) Selbstregierung durch freie und faire Wahlen beschränkt ist, übersehen. Andere „Regierungsformen“ - wie jene innerhalb der Ehe oder am Arbeitsplatz - werden üblicherweise vernachlässigt. Demokratie ist für Pateman demgemäß nicht nur die kollektive Selbstregierung durch das allgemeine Wahlrecht, sondern darüber hinausgehend ist für sie auch der Aspekt der individuellen Selbstregierung bzw. Autonomie zentral. Damit wird der Blickwinkel nicht nur auf staatliche Institutionen beschränkt, sondern insofern erweitert, dass auch andere gesellschaftliche Institutionen (Ehe, Arbeitsverhältnisse,...) in den Blick genommen werden. Kollektive Selbstregierung und individuelle Autonomie sind für sie zwei miteinander verbundene Konzepte. Die Einschränkung der individuellen Autonomie durch gesellschaftliche und ökonomische Strukturen und Institutionen hat Auswirkungen auf die Partizipation an der kollektiven Selbstregierung beziehungsweise die Förderung der individuellen Autonomie würde sich auf die kollektive Selbstregierung im Sinne einer Demokratisierung auswirken (vgl. Pateman 2004: 15ff)

Helen O'Connell konstatiert daher: „Feminist democracy needs feminist economics, and feminist economics are necessary to achieve sustainable feminist democracy $(\ldots)$ it is not possible for anyone to enjoy and exercise their full human rights within the global economy as it is currently structured" (O'Connell 2007: 15).

Obgleich sich feministische Demokratietheorien überwiegend am politischdemokratischen Input orientieren, zielen sie auch auf den Output politischer Prozesse beziehungsweise die Frauenfreundlichkeit von politischen Organen ab. Eine frauenfreundliche ("woman-friendly") ebenso wie die Unterschiede zwischen Frauen anerkennende Politik portraitiert Kathleen Jones als „root[ing] its democracy in the experiences of women and transform[ing] the practice and concept of citizenship to fit these varied experiences, rather than simply transform[ing] women to accommodate the practices of citizenship as it traditionally 
has been defined“" (Jones 1990: 811). Frauenfreundliche Demokratien werden zumeist dann als solche bezeichnet, wenn sie ideale, geschlechtergerechte sowie feministische Politiken implementieren, die Frauen empowern und Frauen von Unterdrückung und Herrschaft befreien (vgl. Vickers 2006: 1, 19).

Für die Definition von frauenfreundlichen Politiken verweist Amy Caiazza außerdem auf die Richtlinien der Beijing Declaration and Platform for Action der 4. Frauenweltkonferenz: Diese ,outline critical issues of concern to women and remaining obstacles to women's advancement, including the need for policies that help prevent violence against women; promote women's economic equality; alleviate poverty among women; improve their physical, mental, and reproductive health and well-being; and enhance their political power" (Caiazza 2002: 2).

Jedenfalls braucht Frauenfreundlichkeit als Minimum zunächst eine signifikante Repräsentation von Frauen in entscheidungsbefugten Positionen auf allen politischen Ebenen „with enough ,clout' to influence decisions“ (Vickers 2006: 21) ebenso wie eine volle aktive Staatsbürgerinnenschaft von Frauen (vgl. auch Kapitel 4.2.3 und 4.3.2).

Außerdem kann die Frauenfreundlichkeit einer Demokratie laut Jill Vickers anhand folgender Faktoren gemessen werden:

- anhand ihrer Verpflichtung alle Frauen fair zu behandeln, ,which doesn't always mean treating them the same" (Vickers 2006: 21)

- anhand ihrer Anstrengungen frauendiskriminierende Gesetze und Politiken zu beseitigen ebenso wie deren Effekte zu kompensieren

- anhand der staatlichen Unterstützung für Frauen und Männer bei Pflegeund Betreuungsarbeit, „facilitating women's paid and political work“ (Vickers 2006: 22)

- und anhand eines ,addressing [of] issues of particular concern for specific groups of women, especially regarding physical and economic security, and their sexual and reproductive health and self-determination" (ebd.)

\subsection{Zwischenfazit: Kriterienkatalog feministischer Demokratie- theorien}

Die in Kapitel 4.2 bis 4.4 mit Hilfe der Strukturierenden Inhaltsanalyse mit inhaltlicher Vorgehensweise anhand der drei Hauptkategorien Input, Institutionen und Output erarbeiteten Kriterien habe ich zu dem im Folgenden aufgelisteten Kriterienkatalog zusammengestellt (vgl. Tabelle 3). Diese Zusammenstellung der vierzehn teils miteinander verwobenen Kriterien stellt die Voraussetzungen für eine geschlechtergerechte demokratische Gestaltung der Finanzpoli- 
tik dar und kann demgemäß eine theoretische Basis der Präzisierung und Fundierung eines Demokratieverständnisses für Gender Budgeting bilden.

\section{Tabelle 3: Überblick Kriterienkatalog feministischer Demokratietheorien}

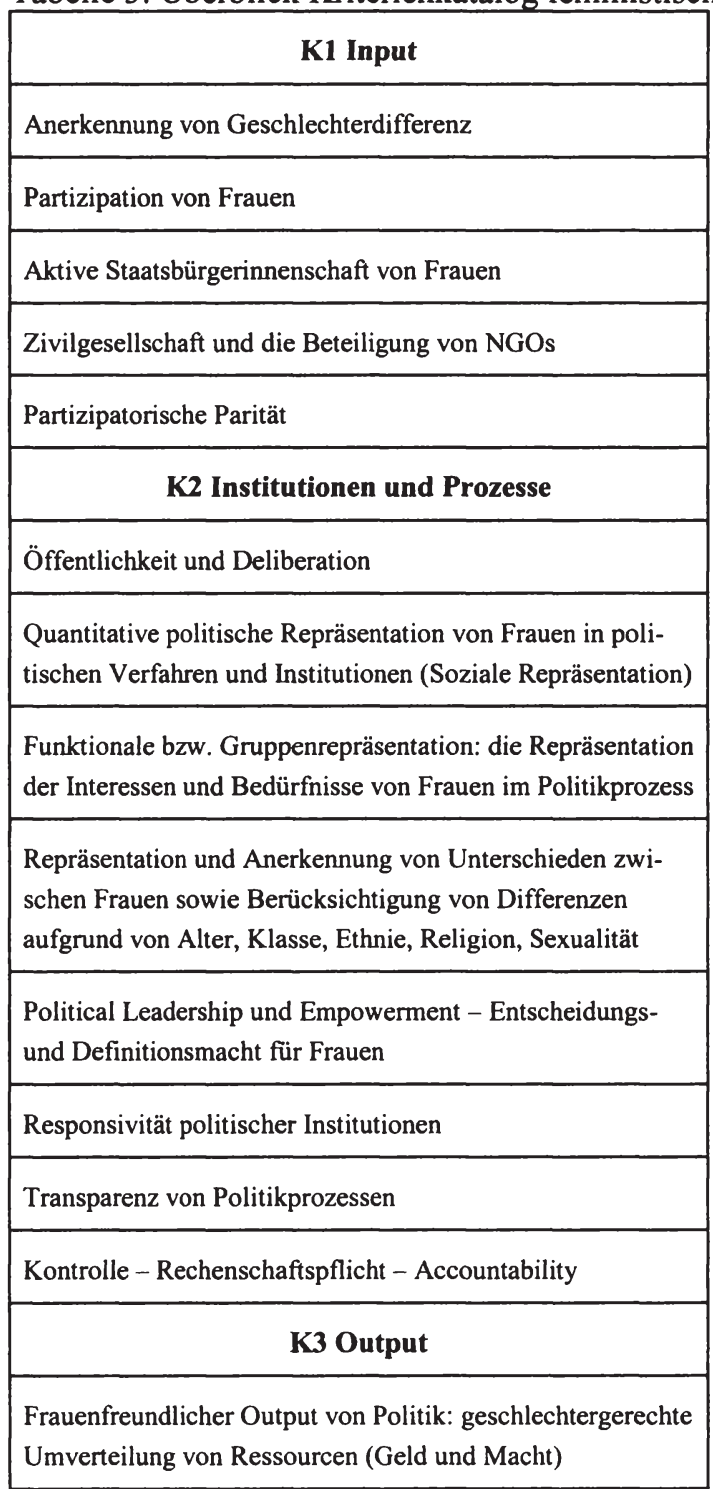

Quelle: eigene Darstellung 
Die einzelnen Kriterien können in einem nächsten Schritt in den Budgetprozess integriert werden indem sie an die unterschiedlichen Phasen des Budgetprozesses herangetragen werden. Dies stellt ein anspruchsvolles Unterfangen dar, da die Kriterienintegration auf mehreren Ebenen - strukturell, prozedural und inhaltlich - ansetzen muss. Die Kriterien erhalten in den verschiedenen Phasen jeweils unterschiedliche Gewichtung, sie überlappen einander teilweise, sollen jedoch insgesamt einer geschlechtergerechten demokratischen Öffnung und Erweiterung von Budgetprozessen dienen. 
Katharina Mader - 978-3-631-75378-1

Downloaded from PubFactory at 01/11/2019 05:43:12AM

via free access 


\section{Integration feministischer Demokratiekriterien in den Wiener Budgetprozess}

Im Folgenden werde ich anhand des in Kapitel 4 erarbeiteten Kriterienkatalogs, den Versuch einer Integration dieser Kriterien in den Budgetprozess und damit einen Vorschlag zur geschlechtergerechten und emanzipatorischen Demokratisierung von Budgetprozessen machen, indem ich eine mögliche - systemimmanente - demokratische Transformation des Wiener Budgetprozesses skizziere. Mit einer solchen Demokratisierung ist durchaus auch die Perspektive einer radikalen geschlechterdemokratischen Erweiterung von Finanzpolitik denkbar und intendiert.

Um den Kriterienkatalog an den Budgetprozess herantragen zu können, muss dieser zunächst in unterschiedliche Phasen aufgespaltet und der budgetpolitische Entscheidungsprozess als Phasenmodell erfasst werden. Hierfür bietet sich die in der finanzwirtschaftlichen Literatur verbreitete Darstellung des Budgetprozesses als Budgetkreislauf an. Damit können die unterschiedlichen Abschnitte des budgetpolitischen Entscheidungsprozesses dargestellt und feministische Demokratisierungsimpulse auf inhaltlicher, institutioneller und prozessualer Ebene in die verschiedenen Phasen des Kreislaufes eingearbeitet werden.

Dementsprechend werde ich zunächst das allgemeine Modell eines Budgetkreislaufes sowie dessen einzelne idealtypische Phasen vorstellen. Diesen Kreislauf adaptiere ich in einem nächsten Schritt für die Phasen des Wiener Budgetprozesses. Anschließend ordne ich den einzelnen Phasen des Wiener Budgetkreislaufs die entsprechenden feministisch- demokratietheoretischen Kriterien zu und erarbeite Vorschläge zur institutionellen beziehungsweise prozessualen Umsetzung der geschlechterdemokratischen Überlegungen.

\subsection{Der Budgetprozess als Kreislauf}

Im Budget werden Ausgabenvorhaben den erwarteten Einnahmen gegenübergestellt und vollzugsverbindlich beschlossen (vgl. Kapitel 3). „Infolge der wiederkehrenden Abläufe spricht man auch von einem Budgetkreislauf" (Blankart 2003: 436). Dieser „Prozess des Budgetkreislaufes hat 4 Phasen: Erstellung, parlamentarische Beratung und Verabschiedung, Vollzug und Kontrolle" (Nowotny 1999: 179). In der finanzwissenschaftlichen Literatur besteht ein breiter Konsens darüber, Budgetprozesse - wie in Abbildung 9 verdeutlicht - als sich jährlich wiederholende Kreisläufe mit vier Phasen darzustellen (vgl. ebd.: 179ff, Blankart 2003: 436ff, Rossmann/Schlager 2006: 4ff und Sharp 2003: 38). Die Essenz des Budgetprozesses ist hierbei ,to present planned expenditures and revenues for the forthcoming year" (Sharp 2003: 38). 
Abbildung 9: Phasen des Budgetkreislaufes

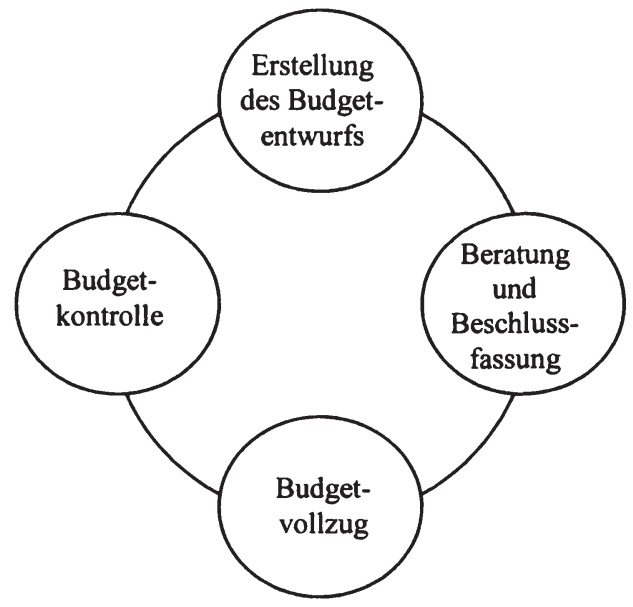

Quelle: Blankart 2003: 436, Rossmann/Schlager 2006: 4ff, eigene Darstellung

Die Erstellung des Budgetentwurfs erfolgt durch die Exekutive (vgl. Nowotny 1999: 179), ihr vorgelagert sind Vorgaben und Regelungen auf Europäischer Ebene, eine nationale politische Klärung strategischer Zielsetzungen, ebenso wie eine strategische Planungsphase, in die alle föderalen Ebenen (in Österreich also Bund, Länder und Gemeinden) eingebunden werden (vgl. Rossmann/Schlager 2006: 4).

Der auf Basis dieses Verfahrens erstellte Entwurf des Voranschlags wird anschließend zur Behandlung, Beratung und Verabschiedung im Parlament eingebracht (vgl. ebd., Blankart 2003: 437), womit das Budget zu einem öffentliches Dokument wird (vgl. Sharp 2003: 38).

Das von der Legislative beschlossene Budget kann nun von der Regierung beziehungsweise Verwaltung beim Vollzug ihrer Aufgaben eingesetzt werden, die „Verwaltung hat nun die Aufgabe, das im Budget zum Ausdruck kommende Regierungsprogramm durchzuführen" (Nowotny 1999: 180). Ergibt sich während des Budgetvollzugs die Notwendigkeit von Mehrausgaben gegenüber den Budgetansätzen, so ist dafür in Österreich eine Änderung des Bundesfinanzgesetzes nötig (vgl. Rossmann/Schlager 2006: 5).

Das Budgetergebnis eines Finanzjahres wird zunächst als vorläufiger Gebarungserfolg der Öffentlichkeit präsentiert und anschließend einer umfangreichen Budgetkontrolle unterzogen. In dieser Kontrolle soll „überprüft werden, ob sich Regierung und Verwaltung tatsächlich an das Budget gehalten haben" (Blankart 2003: 438). Sie erfolgt auf drei Ebenen: Budgetbegleitend wird eine verwal- 
tungsinterne Kontrolle schon während des Vollzugs durchgeführt. Die fachliche Kontrolle nimmt der Rechnungshof vor. Die Ergebnisse werden im Rechnungsabschluss festgehalten. Abschließend erfolgt die politische Kontrolle durch das Parlament, „der Budgetkreislauf schließt mit der Entlastung der Regierung durch das Parlament" (ebd.).

\subsection{Der Wiener Budgetprozess und -kreislauf}

Im Zusammenhang mit dem Budgetprozess in Wien ist zunächst zu beachten, dass Wien gleichzeitig ein Bundesland und eine Gemeinde ist. Ein Budget wird jedoch nur für Wien als Gemeinde erstellt, da die Verwaltungsangelegenheiten von Wien als Land gemäß §132 Abs. 4 der Wiener Stadtverfassung (WStV) von der Gemeinde übernommen werden. Gemeinden haben laut Art. 116 Abs. 2 des Bundes-Verfassungsgesetz (B-VG) das Recht ihren Haushalt im Rahmen der Finanzverfassung selbstständig zu führen. Demgemäß finden sich auch die grundsätzlichen Festlegungen zum Wiener Budgetprozess in der Wiener Stadtverfassung ab $\S \S 84$.

Auch der Wiener Budgetprozess ist ein sich jährlich wiederholenden Kreislauf mit vier grundsätzlichen Phasen, der daher ebenso wie der allgemeine Budgetprozess in Kapitel 5.1 als Budgetkreislauf dargestellt werden kann.

Abbildung 10: Adaptierter Budgetkreislauf für Wien

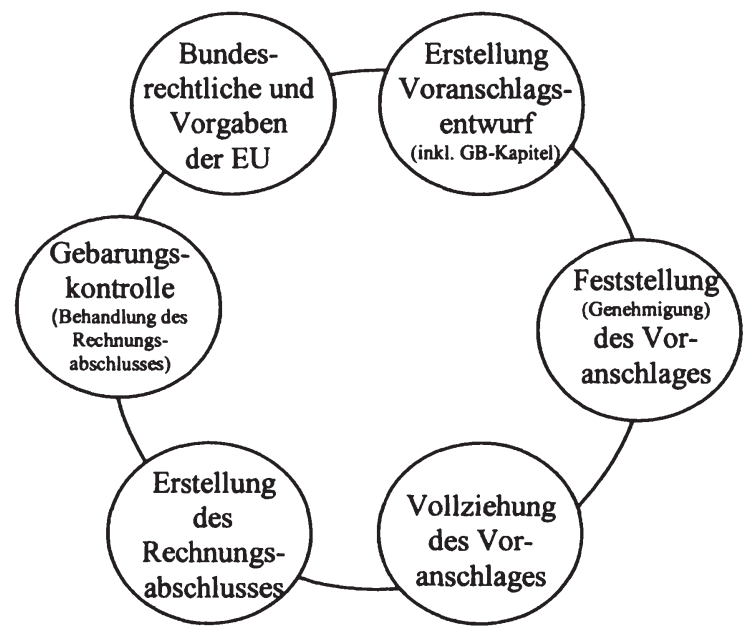

Quelle: eigene Darstellung

Die vier allgemeinen Phasen der Erstellung, Verabschiedung, des Vollzug und der Kontrolle habe ich in Abbildung 10 um die zwei vorgelagerten Phasen 
„Bundesrechtliche und Vorgaben der EU“ und „Erstellung des Rechnungsabschlusses" erweitert. Die erste Phase ist insofern bedeutend, als dem Budgetprozess auf Gemeindeebene bundesrechtliche Vorgaben, wie die des Finanzausgleiches $^{45}$ sowie Vorgaben und Regelungen auf Europäischer Ebene, wie die Maastricht-Kriterien ${ }^{46}$, die wiederum in der bundesrechtlichen Regelung des Österreichischen Stabilitätspaktes ${ }^{47}$ wirksam werden, vorgelagert sind. Diese Rahmenbedingungen und Strategien beeinflussen den Handlungsspielraum finanzpolitischer Politiken auf kommunaler Ebene massiv und sollten daher in jedem Fall im Zuge einer Gender Budgeting-Initiative berücksichtigt werden (vgl. Schuberth 2006: 53). Die zweite zusätzliche Phase der Erstellung des Rech-

45 In Österreich werden die einnahmenseitigen Beziehungen zwischen den Gebietskörperschaften, also die Abgabenhoheit, im Finanzverfassungsgesetz geregelt. Während sowohl Bund, Länder als auch Gemeinden Abgaben einheben können, stellen die vom Bund eingehobenen Abgaben die weitaus wichtigsten öffentlichen Einnahmequellen dar. Die Aufteilung dieser Abgabenerträge wird im Finanzausgleich vereinbart, in dessen Wege den Gebietskörperschaften die notwendigen Mittel zur Besorgung ihrer Aufgaben aus den öffentlichen Einnahmen zugeteilt werden. Der österreichische Finanzausgleich bildet somit die Basis der Finanzierung von Bund, Ländern und Gemeinden durch Bestimmungen über Aufwandstragungen, Transfers und Steuerteilungen. Die Bestimmungen über (gegenseitige) Kostentragung und Transfers werden jeweils in dem für mehrere Jahre geltenden Finanzausgleichsgesetz konkretisiert (vgl. Nowotny 1999: 142, Fleischmann 2002: 20, Matzinger 2002: $51 \mathrm{ff}$ ). Die sich aus dem Finanzausgleich ergebenden finanziellen Verflechtungen sind äußerst umfangreich, komplex, ausufernd und intrasparent und erlauben kaum eine systematische Nachvollziehbarkeit (vgl. Bröthaler et al 2006: 8).

46 Im Vertrag von Maastricht (1992) wurden vier Kriterien als Fundament der Wirtschaftsund Währungsunion (WWU) und als Eintrittsbedingungen für EU-Mitgliedsstaaten in den Kreis der WWU-Länder festgelegt. Um eine möglichst hohe wirtschaftliche Konvergenz der Teilnehmerländer zu gewährleisten zielen diese Kriterien auf niedrige Inflationsraten, niedrige Zinsen, stabile Wechselkurse und auf die Vermeidung übermäßiger öffentlicher Defizite ab. Als Referenzwerte für ein übermäßiges Defizit wurden maximal 3\% des BIP für die Neuverschuldung und maximal $60 \%$ des BIP für den öffentlichen Schuldenstand eingeführt. Im Stabilitäts- und Wachstumspakt (1997) wurde die Einhaltung dieser Konvergenzkriterien auch über den WWU-Eintritt hinaus fortgeschrieben um eine Haushaltsdiziplin der WWU-Länder auf Dauer zu erreichen (vgl. Part 1998: 38f und 2002: 28f).

47 Um einen WWU-Beitritt Österreichs zu gewährleisten vereinbarten die Gebietskörperschaften zunächst eine informelle Aufteilung der Defizitquote um die erforderliche gesamtstaatliche Haushaltskonsolidierung zu erreichen. Seit dem Inkraftreten des ersten offiziellen Österreichischen Stabilitätspaktes im Jahr 1999 werden mit dem innerösterreichischen Stabilitätspakt die Beiträge, die Bund, Länder und Gemeinden zur Erreichung der gesamtstaatlichen Budgetziele beziehungsweise zur innerstaatlichen Haushaltskoordinierung zu leisten haben, gesetzlich festgelegt. Der österreichische Stabilitätspakt und der Finanzausgleich werden abhängig von einander abgeschlossen, denn die Ausstattung der Gebietskörperschaften mit Finanzmitteln hat großen Einfluss auf ihre Möglichkeiten, die Ziele des Stabilitätspaktes zu erreichen (vgl. Schratzenstaller 2005: 49). 
nungsabschlusses ${ }^{48}$ ist deshalb relevant, weil im Zuge der politischen Gebarungskontrolle auch der Rechnungsabschluss behandelt werden muss.

\subsubsection{Erstellung des Voranschlagsentwurfes}

Der Wiener Voranschlag, seiner Rechtsnatur nach eine Verordnung, bildet die Grundlage der finanziellen Gebarung der Wiener Gemeindeorgane für das kommende Verwaltungsjahr. Er entfaltet seine Bindungswirkung nur nach innen sowie hier nur auf der Ausgabenseite.

Die/der amtsführende FinanzstadträtIn muss dem Finanzausschuss des Gemeinderates und dem Stadtsenat gemäß $\S 86$ Abs. 1 Wiener Stadtverfassung mindestens sechs Wochen vor Beginn eines Verwaltungsjahres einen Voranschlagsentwurf vorlegen. Dieser basiert auf Teilvoranschlagsentwürfen, die von den anordnungsbefugten Dienstellen unter Mitwirkung der zuständigen Buchhaltungsabteilungen verfasst und von den zuständigen amtsführenden StadträtInnen genehmigt wurden. Die Teilvoranschlagsentwürfe werden gemäß $\S 105$ Abs. 3 lit. c Wiener Stadtverfassung von der Magistratsabteilung $5 \mathrm{zu}$ einem Rohbudget zusammengestellt. Dieses dient der/dem FinanzstadträtIn als Unterlage für eventuell erforderliche Budgetbesprechungen. Unter Berücksichtigung etwaiger im Zuge der Verhandlungen vorgenommener Veränderungen wird der Voranschlagsentwurf verfasst und dann der Genehmigung durch den Gemeinderat zugeführt (vgl. WStV).

Seit 2006 wird im Zuge der Erstellung des Voranschlagsentwurfes auch ein eigenes Kapitel zu Gender Budgeting erarbeitet (vgl. dazu genauer Kapitel 3.2.2.1.1).

\subsubsection{Feststellung (Genehmigung) des Voranschlages}

In Folge müssen der Finanzausschuss und der Stadtsenat den Voranschlagsentwurf in einer gemeinsamen Sitzung prüfen und vorberaten (§95 Abs. 2 WStV). Parallel dazu ist auch der so genannte Gebührenspiegel zu behandeln, in dem der Kostendeckungsgrad für die einzelnen Gebühren und Entgelte der Gemeinde dargestellt wird ( $\$ 86$ Abs. $6 \mathrm{WStV})$.

Anschließend liegt der Voranschlagsentwurf während einer Woche zur öffentlichen Einsicht in den magistratischen Bezirksämtern 1/8 und 4/5 sowie in den

48 Nach Ablauf eines Verwaltungsjahres ist durch Zusammenwirken von anordnungsbefugten Dienststellen und zuständigen Buchhaltungsabteilungen für jeden Ansatz ein Teilrechnungsabschluss aufzustellen. Diese sind an die Magistratsabteilung $5 \mathrm{zu}$ übermitteln und werden von eben dieser zusammengestellt. Für die Genehmigung des Rechnungsabschlusses sind die Vorlage an Finanzausschuss und Stadtsenat, deren Beratung in gemeinsamer Sitzung, die einwöchige Auflage zur öffentlichen Einsicht und die Beratung und Genehmigung im Gemeinderat in zwingend öffentlicher Sitzung nötig (vgl. Kapitel 5.2.2). 
Dienststellen des Bürgerdienstes, der Stadtinformation und in der Magistratsabteilung 5 auf. Die Gemeindemitglieder haben nun das Recht Stellungnahmen abzugeben. Diese werden zu Protokoll genommen und müssen bei der Beratung durch den Gemeinderat erwogen werden. Die folgende Beratung durch den Gemeinderat und die Genehmigung beziehungsweise die Feststellung des Voranschlages erfolgt zwingend in einer öffentlicher Sitzung ( 22 Abs. 2 WStV).

\subsubsection{Vollziehung des Voranschlages}

Zur Vollziehung des Voranschlages ist eine Anordnungsbefugnis nötig, die jedes Tätigwerden aus dem sich eine Zahlungsverpflichtung für die Stadt Wien (Ausgabe) oder Dritte (Einnahme) ergibt, formale Feststellungen des Anspruches (beispielsweise Steuerbescheide) sowie Anordnungen der Gebührstellung und Zahlung (Abstattung), umfasst. Welcher Dienststelle die Anordnungsbefugnis für welchen Ansatz des Voranschlages zukommt, richtet sich nach der Geschäftseinteilung für den Magistrat der Stadt Wien. Gegebenenfalls können die LeiterInnen von anordnungsbefugten Dienststellen anderen Dienststellen Mittel zur Bewirtschaftung im Rahmen von Referatskrediten übertragen.

Abgesehen davon sind bei der Ausübung der Befugnis zur Anordnung von Einnahmen und Ausgaben auch die Zuständigkeitsbestimmungen der Wiener Stadtverfassung sowie die darin bestimmte eventuelle Notwendigkeit der Einholung einer sachlichen Genehmigung zu beachten: Eine Bedeckung von Ausgaben im Voranschlag bedeutet noch nicht, dass die anordnungsbefugten Dienststellen die Ausgaben ohne weiteres tätigen können, denn für bestimmte - betragsmäßig abgegrenzte Ausgaben gibt es Genehmigungsvorbehalte (Zuständigkeiten) des Gemeinderatsausschusses beziehungsweise des Gemeinderates. Hierfür wird sich eines Basiswertes bedient, der jährlich neu zu berechnen ist (§ 88 Abs. 1 lit. e WStV).

\subsubsection{Gebarungskontrolle}

Im Zuge des Rechtes der Oberaufsicht darf der Gemeinderat die Geschäftsführung in allen Angelegenheiten seines eigenen Wirkungsbereiches untersuchen beziehungsweise untersuchen lassen. Der gemäß der WStV obligatorisch einzurichtende Finanzausschuss ist berechtigt die Gebarungskontrolle auszuüben und sich zu diesem Zweck alle ihm erforderlich erscheinenden Geschäftsstücke vorlegen zu lassen ( $\$ 49$ Abs. 2 WStV).

Das Kontrollamt prüft im Rahmen der Gebarungskontrolle die gesamte Wirtschafts- und Haushaltsführung der Gemeinde Wien sowohl in formaler als auch sachlich Hinsicht auf die ziffernmäßige Richtigkeit, Ordnungsgemäßheit, Sparsamkeit, Wirtschaftlichkeit und Zweckmäßigkeit. 
Die Prüfungstätigkeit des Kontrollamts umfasst unter anderem die Prüfung der Einnahmen und Ausgaben, der Vermögensgebarung, der buchmäßigen Aufzeichnung, der Einhaltung des Voranschlages, der Kassen- und Sachbestände. Auf Beschluss des Gemeinderates, des Kontrollausschusses, auf Ersuchen des Bürgermeisters oder der amtsführenden StadträtInnen (jeweils für den Bereich ihrer Geschäftsgruppen) kann das Kontrollamt auch besondere Akte der Gebarungsprüfung durchführen. Jährlich erstattet das Kontrollamt dem Gemeinderat Bericht, die Vorberatungen dazu obliegen dem Kontrollausschuss ( $§ 73 \mathrm{WStV}$ ).

Die Gebarung der Stadt Wien unterliegt gemäß Art. 127 Abs. 8 B-VG auch der Kontrolle durch den Rechnungshof. Die Ergebnisse der Überprüfung durch den Rechnungshof werden dem Stadtsenat bekannt gegeben, der dazu Stellung nehmen und die aufgrund der Prüfungsergebnisse getroffenen Änderungen und Maßnahmen bekannt geben muss. Laut $\S 73 \mathrm{a}$ WStV haben 33 Gemeinderatsmitglieder das Recht vom Rechnungshof eine Durchführung besonderer Akte der Gebarungsprüfung zu verlangen, wobei jedes Gemeinderatsmitglied pro Kalenderjahr nicht mehr als zwei solcher Verlangen unterstützen darf.

\subsection{Feministisch-demokratietheoretische Erweiterung des Wiener Budgetkreislaufes}

Wie könnte nun eine feministisch-demokratische Transformation des Wiener Budgetprozesses anhand des vorliegenden Kriterienkataloges aussehen?

Vor dem Hintergrund der relativen Wirkungslosigkeit der Wiener Gender Budgeting-Initiative und der Diskrepanz zwischen den theoretischen Ansprüchen per definitionem und der Umsetzung in der Praxis (vgl. Kapitel 3.2.2.1) werde ich im Folgenden anhand einer Anwendung der feministisch-demokratietheoretischen Kriterien in den einzelnen Phasen des Wiener Budgetkreislaufes Vorschläge zur geschlechtergerechten demokratischen Öffnung beziehungsweise Erweiterung des Wiener Budgetprozesses erarbeiten. Diese werden sich wiederum systematisch auf alle drei Ebenen beziehen: auf die Ebene des demokratisch-politischen Inputs, die Ebene der demokratisch-institutionellen Arrangements und Bedingungen um den Budgetprozess geschlechtergerechter, transparenter, inklusiver und partizipativer zu gestalten sowie auf die Ebene des politischen Outputs um mit Gender Budgeting einen frauenfreundlichen Politikinhalt sowie Geschlechtergerechtigkeit zu erreichen.

Ich werde im Folgenden jedoch nicht „die eine“ Patentlösung für „den“ geschlechterdemokratischen Budgetkreislauf darstellen, denn eine geschlechtergerechte Demokratisierung des Budgetprozesses bedeutet, dass dieser immer wieder neu verhandelt werden muss und dass möglichst viele unterschiedliche Frauen die Möglichkeit erhalten, an diesem Aushandlungsprozess teilzunehmen sowie ihre Bedürfnisse, Perspektiven und Betroffenheiten in den Entscheidungs- 
findungsprozess einbringen zu können. Die Integration der feministisch-demokratischen Kriterien soll daher in den einzelnen Phasen des Budgetkreislaufes Demokratisierungsimpulse und -anreize bieten, aufgrund derer Frauen einerseits die Chance bekommen am Budgetprozess teilzunehmen und andererseits in den Budgetprozess eingelassene Geschlechterverhältnisse und Geschlechterungerechtigkeiten aufgebrochen werden können und einer Reproduktion von sozialen Ungleichheiten entgegen gewirkt werden kann. Wie Abbildung 11 zeigt, erhalten die vierzehn Kriterien in den unterschiedlichen Phasen des Budgetkreislaufes unterschiedliche und besondere Gewichtung.

Abbildung 11: Wiener Budgetkreislauf erweitert um feministisch-demokratietheoretische Kriterien

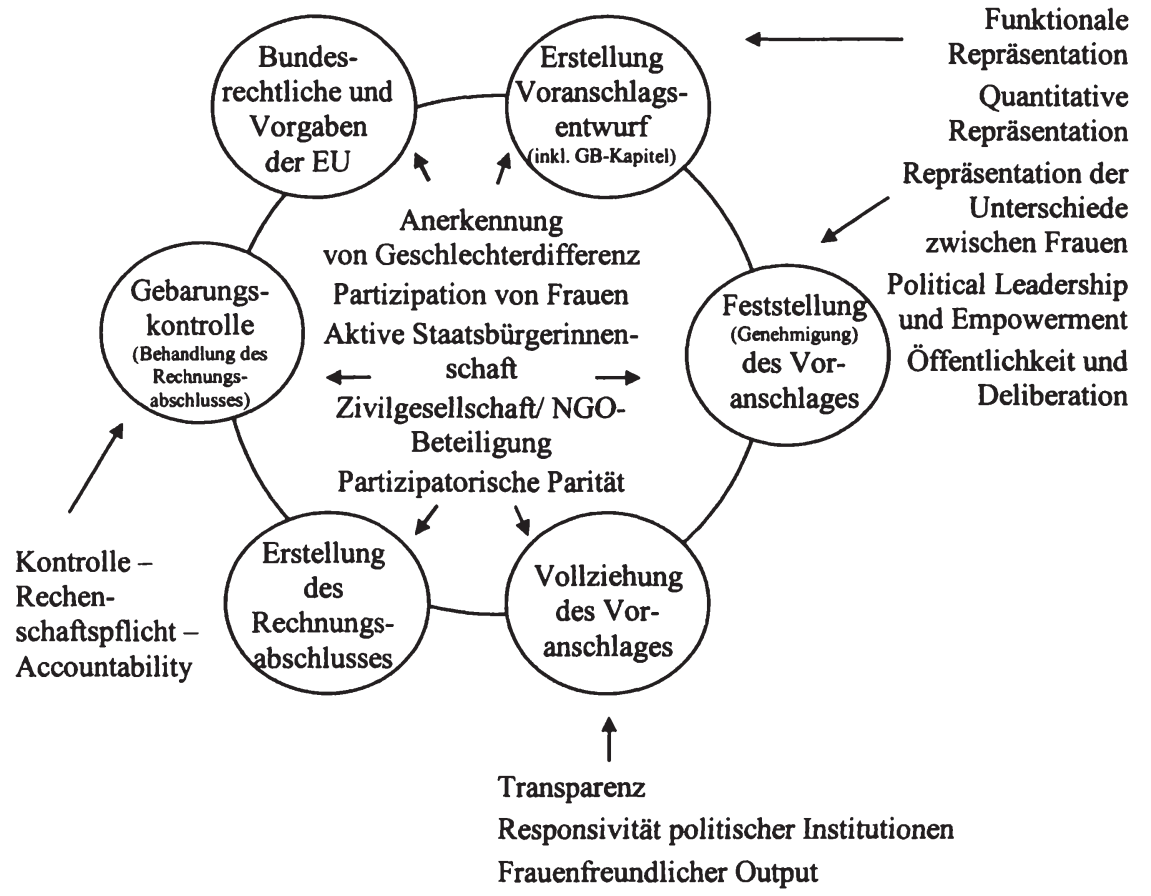

Quelle: eigene Darstellung

Die Kategorien Anerkennung von Geschlechterdifferenz, Partizipation von Frauen, aktive Staatsbürgerinnenschaft von Frauen, Zivilgesellschaft und NGOBeteiligung und Partizipatorische Parität sind in allen Phasen von Bedeutung. Diese generellen beziehungsweise Input-Prinzipien sind während des gesamten Entscheidungsprozesses zu berücksichtigen. In den Phasen der Erstellung und 
Feststellung des Voranschlagsentwurfs sind darüber hinaus auch die Quantitative sowie Funktionale Repräsentation, die Repräsentation der Unterschiede zwischen Frauen, Political Leadership sowie Empowerment von Frauen und Öffentlichkeit bzw. Deliberation zentrale geschlechterdemokratische Kategorien. Im Laufe der Vollziehung des Voranschlags gewinnen vor allem die Kriterien der Transparenz des Budgetprozesses, der Responsivität budgetpolitischer Institutionen sowie des Frauenfreundlichen Output an Wichtigkeit. Bei der Gebarungskontrolle wiederum spielt der Kriterienkomplex der Kontrolle - Rechenschaftspflicht - Accountability eine zentrale Rolle.

\subsubsection{Generelle feministisch-demokratische Bedingungen für den Wiener Budgetkreislauf}

Da Demokratisierung in einem ersten Schritt bedeutet, Ungleichheiten in der politischen Entscheidungskompetenz durch die Einführung und den Ausbau von Einflussnahme-, Beteiligungs- und Mitwirkungsmöglichkeiten an politischen Entscheidungen aufzuheben.

Abbildung 12: Generelle bzw. Inputkriterien für den gesamten Budgetkreislauf

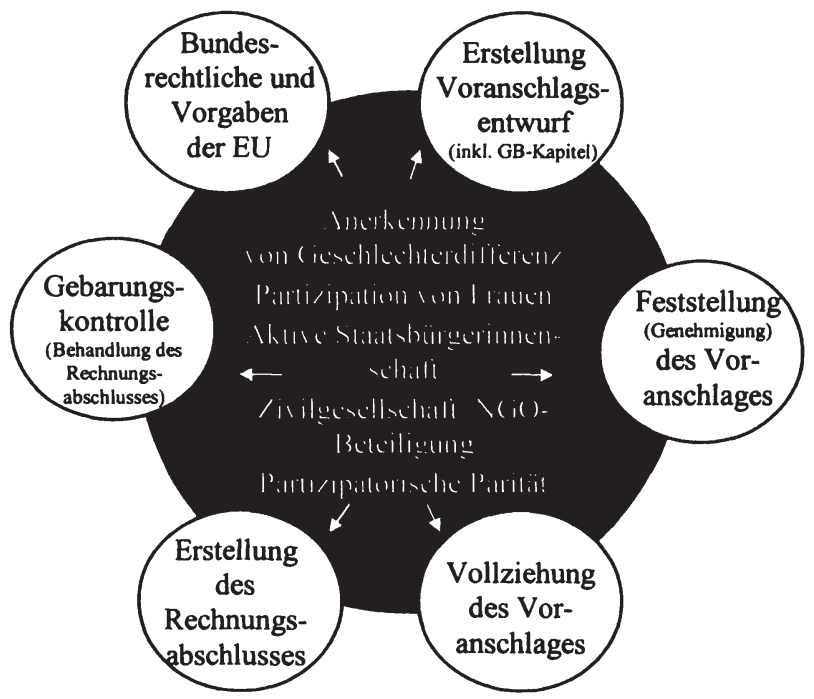

Quelle: eigene Darstellung

Daher verstehe ich die fünf Kriterien des demokratischen Input (K1) als jene generellen Prinzipien, die während des gesamten budgetpolitischen Entscheidungsprozesses zu berücksichtigen sind. Daher sind sie auch - um feministisch- 
demokratische Impulse setzen zu können - in jeder Phase des Budgetkreislaufes von Bedeutung (vgl. Abbildung 12).

In der Gender Budgeting-Literatur wurde herausgearbeitet, dass Finanz- und Wirtschaftspolitik sowie Budgets nicht geschlechtsneutral sind, sondern vielmehr Geschlechterverhältnisse widerspiegeln und ungleiche geschlechtsspezifische Macht- und Ressourcenverteilungen (re-) produzieren (vgl. Angelo et al 2003: 29, BEIGEWUM 2002: 12 und Michalitsch 2003: 228). Für eine feministisch-demokratische Transformation eines Budgetprozesses ist demgemäß in einem ersten Schritt der vermeintlichen Neutralität des Budgetprozesses entgegenzuwirken: Im Zuge einer Anerkennung von Geschlechterdifferenz können die in Budgetprozessen eingeschriebenen, impliziten und vorbewussten $\mathrm{Ge}$ schlechterverhältnisse deutlich gemacht werden. Geschlechterdifferenz bezeichnet die sozial hergestellte Unterschiedlichkeit von Erfahrungen, Identitäten und Interessen und verknüpft die Idee von politischer mit sozialer Gleichheit: Nur wenn Frauen den Männern nicht gleich gemacht werden, ist die Voraussetzung für politische Gleichheit von Frauen und Männern gegeben. Politische Gleichheit bedeutet in diesem Sinne eine vollständige Partizipation und Inklusion aller (vgl. Young 1990: 173). Diese kann solange nicht erreicht werden, als sexistische, androzentristische, abwertende und missachtende Muster und Normen in und durch politische Prozesse, wie den Budgetprozess, festgeschrieben und institutionalisiert werden. Beispielsweise wird in der Finanzpolitik davon ausgegangen, dass das Budget alle Bürgerinnen und Bürger in gleicher Art und Weise betrifft und daher nur die Bedürfnisse von Durchschnittspersonen zu befriedigen sind (vgl. dazu kritisch Schratzenstaller et al 2006: 2).

Diese Durchschnittsperson ist jedoch von spezifischen hegemonialen Männlichkeitsmustern geprägt, denen Frauen unterworfen sind, an denen sie gemessen werden, anhand derer sie unfähiger und abweichend erscheinen und die sich ihnen gegenüber als Nachteil erweisen, im Zuge des Budgetprozesses als NichtBefriedigung ihre Bedürfnisse durch öffentliche Mittel.

Folglich müssen Maßnahmen gegen Ungerechtigkeiten zuallererst an gesellschaftlichen Normen und Wertungen, die Männlichkeit privilegieren und Frauen gleiche Achtung vorenthalten, ansetzen, diese sichtbar machen, damit anschließend auch ihr rechtlicher und institutioneller Ausdruck geändert werden kann. Für einen geschlechtergerechten demokratischen Budgetprozess würde dies ein Sichtbarmachen und eine Reflexion eingeschriebener Geschlechterverhältnisse sowie die Anerkennung der Differenz zwischen Frauen und Männern in allen Phasen des Kreislaufes bedeuten. Hierfür wurden in Wien sicherlich erste kleine Schritte im Zuge von Sensibilisierung beziehungsweise Wissensvermittlung zum Thema Gender für die Finanzexpertinnen und -experten sowie im Zuge der Erstellung von geschlechterdifferenzierten Statistiken gesetzt. 
Eng mit der Forderung nach Anerkennung der Geschlechterdifferenz und der Herstellung von politischer Gleichheit ist die Idee einer vollständigen politischen Partizipation von Frauen verbunden. Die zumeist geringe Partizipationsbereitschaft von Frauen an politischen Entscheidungsprozessen liegt in den strukturellen Exklusionsverfahren des politischen Systems sowie in den fehlenden Partizipationsmöglichkeiten repräsentativer Demokratien begründet: Die mangelnde Partizipation von Frauen korreliert in den etablierten politischen Systemen mit den spezifischen Partizipationsmöglichkeiten in ebendiesen. Daher müssen Frauen außerhalb dieser Systeme die Möglichkeit zur Partizipation bekommen, eine notwendige Voraussetzung hierfür wäre die aktive Schaffung von Zeiten, Orten und Ressourcen für eine politische Beteiligung.

Im Wiener Budgetprozess wurde in zwei Phasen (Feststellung des Voranschlages und Erstellung des Rechnungsabschlusses) zumindest der Zeitpunkt für die Möglichkeit einer Partizipation von Bürgerinnen und Bürgern geschaffen: Nach der Prüfung des Voranschlags- beziehungsweise des Rechnungsabschlussentwurfes durch den Finanzausschuss und Stadtsenat, liegt der Entwurf während einer Woche zur öffentlichen Einsicht auf. Bürgerinnen und Bürger können dazu Stellungnahmen abgeben, die dann zwingend bei der Beratung durch den Gemeinderat erwogen werden müssen. Die Genehmigung des jeweiligen Entwurfes erfolgt außerdem in einer öffentlichen Sitzung.

Doch Interessen, Identitäten und politische Ansichten sind nicht einfach exogen da beziehungsweise fixiert. Es sollte also nicht nur um ein Registrieren von existierenden Präferenzen und Ansichten gehen, sondern darum dass Partizipation einen gemeinsamen, kommunalen und interaktiven Lernprozess darstellt. Hier kommt der transformativen Wichtigkeit und Wirkung von Treffen, Diskussionen und Gesprächen eine Schlüsselbedeutung zu. Die Kreation der eigenen Identitäten sowie die Konstruktion der eigenen Interessen sollten als kontinuierlicher partizipativer Prozess wahrgenommen werden. Dies bedarf im Wiener Budgetprozess beispielsweise der Schaffung einer Art von BürgerInnenforen, die im Idealfall geschlechtergetrennte (um einer prototypischen Rollenübernahme von Frauen wie beim Partizipativen Budget in Porto Alegre entgegenzuwirken), niederschwellige Diskussionsorte darstellen, in denen Platz für Debatten im Zuge der jeweiligen Phasen des Budgetkreislaufes ist. Die Ergebnisse dieser Diskussionsforen müssen dann - so wie die Stellungnahmen in den Phasen Feststellung des Voranschlages und Erstellung des Rechnungsabschlusses - durch die jeweils zuständigen Stellen (einzelne Dienststellen, MA 5, FinanzstadträtIn, Finanzausschuss, Stadtsenat, Gemeinderat, Kontrollamt sowie Rechnungshof) verbindlich behandelt und beachtet werden.

Die Partizipation von Frauen an politischen Entscheidungsprozessen stellt des Weiteren den Kern einer aktiven und vollen Staatsbürgerinnenschaft von Frauen dar. Trotz formal gleicher politischer Rechte besitzen Frauen bis heute einen 
marginalisierten staatsbürgerlichen Status, sie können ihre politischen Rechte nicht im gleichen Maße wie Männer realisieren. Denn der abstrakte und universelle Staatsbürgerstatus ist an männlich gedachten Lebens- und Politikerfahrungen orientiert, transzendiert von jeglicher Partikularität und Differenz und versteht Gleichheit als Gleichsein. Die Orientierung an maskulinistischen Mustern wird in politischen Entscheidungsprozessen zumeist dadurch wirksam, dass Frauen systematisch und strukturell aus der politischen Sphäre und damit von der politischen Willensbildung ausgeschlossen werden. Dementsprechend beruhen auch all jene Themen, die im Zuge des Budgetkreislaufes auf der politischen Agenda erscheinen, auf spezifischen Interessenkonstellationen sowie Zugangsund Einflussmöglichkeiten spezifischer Akteurinnen und Akteure.

Folglich muss für eine geschlechtergerechte Demokratisierung des Wiener Budgetprozesses das Konzept der StaatsbürgerInnenschaft als Maßstab so verändert werden, dass nicht mehr ausschließlich spezifisch männliche Interessen bevorzugt werden. Eine notwendige Rekonstruktion beziehungsweise Neuformulierung von StaatsbürgerInnenschaft impliziert zunächst ein Verwerfen des geschlechtslosen Staatsbürgers als Nutzen maximierendes, rational agierendes, von jeglichen sozialen Bezügen, Kontexten und Abhängigkeiten entkoppeltes Individuum als männliche Fiktion. Des Weiteren bedarf es der Einbeziehung von unbezahlter Arbeit sowie einer Neu-Konzeptualisierung der geschlechtshierarchischen Arbeitsteilung. Das bedeutet für den Wiener Budgetprozess, dass eine wesentliche inhaltliche Erweiterung durch die Berücksichtigung von unbezahlter - zum größten Teil von Frauen geleisteter - Arbeit sowie der indirekten Wirkungen des Wiener Budgets auf diese unbezahlte Tätigkeiten von Nöten ist. Dieser Schüsselaspekt von Gender Budgeting muss in sämtliche Stadien des Budgetprozesses berücksichtigt und miteinbezogen werden, denn die Wirkungen eines Budgets auf Frauen und Männer zeigen sich vor allem im Effekt auf die unbezahlte Arbeit. Und auch hinsichtlich einer Auflösung der Partizipationserschwernisse für Frauen sollten Frauen und Männer in gleichem vollem Umfang bezahlte und unbezahlte Arbeit übernehmen.

Langfristig müsste ein StaatsbürgerInnenschaftsmodell jedoch von einer/einem gender-pluralist-citizen ausgehen (vgl. Kapitel 4.2.3), also einem Konzept, dass Frauen und Männer jeweils als pluralistische Gruppen mit differenten und vielfältigen Identitäten auffasst, deren unterschiedliche Interessen und Bedürfnisse in weiterer Folge im gesamten Budgetkreislauf Berücksichtigung finden.

Ein Ansatzpunkt für die Berücksichtigung der vielfältigen Frauen- und Männerinteressen stellt das Konzept der Zivilgesellschaft und damit verbunden die diversen Möglichkeiten der NGO-Beteiligung dar. Hierbei bedarf es einer Konzeption von Zivilgesellschaft als eine Ausdehnung der politischen Selbstbestimmung von Bürgerinnen und Bürgern, als ein wichtiger - mit dem Staat ambivalent verwobener - Teil der Öffentlichkeit, zu dem die unterschiedlichsten, mar- 
ginalisierten sozialen Gruppen Zugang haben und ihren Anliegen Ausdruck verleihen können. Besonders zentral ist hierbei jedoch, dass in der Zivilgesellschaft eingelassene sexistische und androzentristische Strukturen reflektiert werden und Frauen ein gleichberechtigter Zugang zur Öffentlichkeit gewährleistet wird. Denn Zivilgesellschaft ist erst dann ein Konzept für Frauen, wenn sie Raum für Partizipation und Selbstvertretung von Frauen und somit für Frauenthemen öffnet. Demgemäß gilt die Forderung nach einer geschlechtergerechten Demokratisierung auch für zivilgesellschaftliche Organisationen. Auch die Zivilgesellschaft selbst muss ihre eigenen inhärenten Exklusionsstrategien und Herrschaftsstrukturen reflektieren und überwinden.

Eine konkrete Umsetzungsvariante eines gender-pluralistisches Konzeptes von Zivilgesellschaft im Wiener Budgetprozess könnten beispielsweise öffentliche Anhörungen sein, in denen eine Vielzahl von unterschiedlichen NGOs eingeladen werden und ihre Forderungen und Vorstellungen in den einzelnen Phasen des Budgetprozess einbringen können. Diese Anhörungen sollten Orte der finanzpolitischen Diskussion sein, in denen bewusst auf den Einfluss verschiedener frauenpolitischer NGOs sowie anderer feministischer zivilgesellschaftlicher Gruppierungen und AkteurInnen geachtet wird. Dies würde bedeuten, dass ihnen Orte und ausreichend Redezeit zur Verfügung gestellt wird um ihre Anliegen einzubringen und dass ihre Forderungen jedenfalls behandelt werden müssen. Eine andere beziehungsweise weitere Möglichkeit wären quotierte $\mathrm{Be}-$ ratungsgremien, die mit den unterschiedlichen, unter anderem frauenpolitischen und feministischen NGOs und Gruppen beschickt werden und deren Aufgabe darin bestehen würde, allen Akteurinnen und Akteuren des Wiener Budgetprozesses informierend und beratend zur Seite zu stehen. Hierbei bedarf es auch der aktiven Information der NGOs, diese müssen im Vorfeld alle finanzpolitisch relevante Daten, Dokumente und Studienergebnisse zur Verfügung gestellt bekommen, um eine solche Beratungsfunktion auch optimal ausüben zu können.

Es reicht jedoch nicht aus Frauen und verschiedene frauenpolitische Gruppen im Budgetprozess nur teilnehmen zu lassen, darüber hinaus müssen auch Rahmenbedingungen für Frauen geschaffen werden, die es ihnen ermöglichen, gleichberechtigt mit anderen in den verschiedenen Phasen des Budgetkreislaufes partizipieren, ihre Bedürfnisse realisieren und ihre Interessen durchsetzen zu können. Daher ist es für eine geschlechterdemokratische Öffnung des Budgetprozesses wesentlich, das Konzept der Partizipatorischen Parität in den Prozess zu integrieren.

Hierfür sollten zwei Bedingungen erfüllt werden (vgl. Kapitel 4.2.5): Erstens bedarf es einer gerechten Verteilung materieller Ressourcen um Machtdifferentiale 
zwischen den Bürgerinnen und Bürgern zu verringern und allen eine gleichberechtigte und gleichwertige Stimme zu gewähren. Gerade aufgrund der Verteilungsfunktion von öffentlichen Budgets (vgl. Kapitel 3) könnten mit ihrer Hilfe mehr Verteilungsgerechtigkeit geschaffen und ökonomische Bedingungen gleichmäßiger verteilt werden. Demgemäß sollten in den Wiener Budgetprozess (Geschlechter-) Gerechtigkeitsüberlegungen einfließen beziehungsweise in den Mittelpunkt gerückt werden. Eine größere distributive Gerechtigkeit könnte beispielsweise - wie beim Partizipativen Budget in Porto Alegre - anhand eines Verteilungskriterienkatalogs gewährleistet werden (vgl. dazu Kapitel 3.1.3.3) Zweitens sollten auch die institutionalisierten kulturellen Normen und Werte allen Partizipierenden die gleiche Anerkennung erweisen (vgl. dazu weiter oben Anerkennung der Geschlechterdifferenz).

Alle diese fünf Kriterien des demokratischen Inputs sind während des gesamten Budgetprozesses zu beachten und in allen Phasen des Budgetkreislaufes zu integrieren. Hierbei ist die vorgelagerte Phase der bundesrechtlichen und Vorgaben der $\mathrm{EU}^{49}$ wesentlich, auch wenn diese nur mittelbar von den Akteurinnen und Akteuren des Wiener Budgetprozesses - beispielsweise in den Finanzausgleichsverhandlungen - beeinflusst oder verändert werden kann.

Die Durchsetzung von Zielen der Geschlechtergerechtigkeit auf kommunaler Ebene wird jedoch vor dem Hintergrund der Rahmenbedingungen der EU beziehungsweise des Bundes, die als Konzepte ohne Alternativen präsentiert werden, zusehends schwieriger. Daher sollten Gender Budget-Initiativen um diese Aspekte der Rahmenbedingungen erweitert werden (vgl. auch Schuberth 2006: 53).

\subsubsection{Institutionelle feministisch-demokratische Bedingungen in den Phasen der Erstellung und der Feststellung des Voranschlages}

Abgesehen von der Notwendigkeit der Integration der fünf Inputkriterien (vgl. Kapitel 5.3.1), sind in den beiden Phasen Erstellung des Voranschlagsentwurfes und Feststellung beziehungsweise Genehmigung des Voranschlages fünf weitere spezifisch institutionen- beziehungsweise prozessbezogene Kriterien für eine geschlechtergerechte und emanzipatorische Demokratisierung relevant (siehe Abbildung 13).

49 Diese vorgelagerte Phase inkludiert sowohl die Vorgaben des Bundes als auch die der EU, weil die wichtigsten finanzpolitischen AkteurInnen auf EU-Ebene nach wie vor VertreterInnen der Nationalstaaten sind und finanz- sowie fiskalpolitische Strategien auf EUEbene letztlich über das Einstimmigkeitsprinzip im Rat der Finanzminister, also von den Nationalstaaten, bestätigt werden (vgl. Schuberth 2006: 53ff sowie Kapitel 5.2). 
Abbildung 13: Institutionelle bzw. prozessuale Kriterien für die Phasen Erstellung und Feststellung des Voranschlages

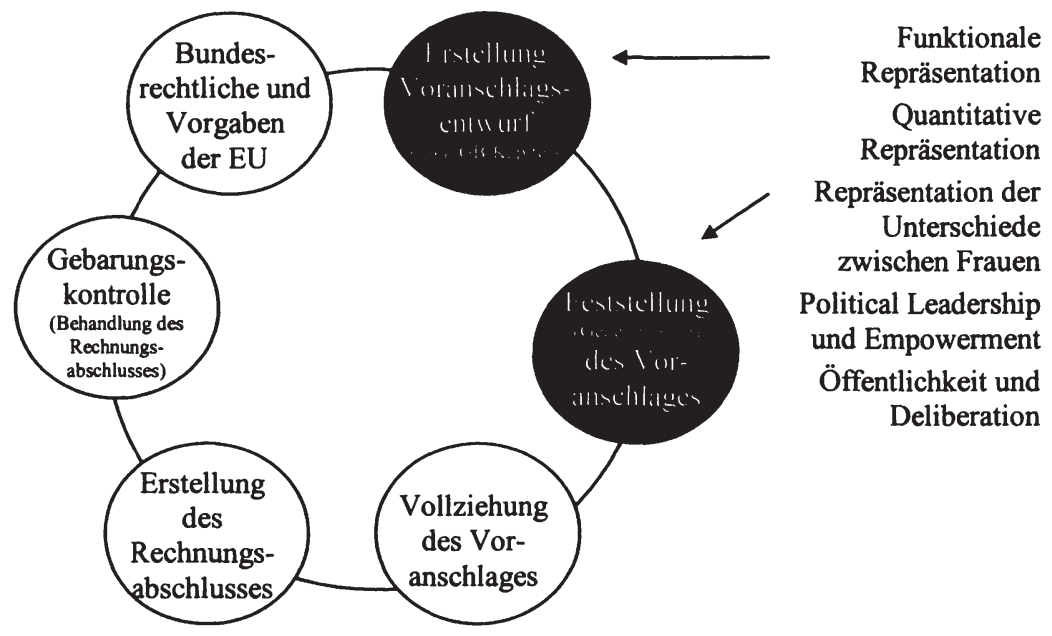

Quelle: eigene Darstellung

In der Gender Budgeting-Literatur wird für eine möglichst weitgehende Partizipation von Frauen argumentiert - auch auf dem Niveau des „official decisionmaking“ (Budlender 2004: 27). Denn zumeist ermöglicht erst eine Präsenz und formal-rechtliche Partizipation von Frauen in entscheidungsbefugten Positionen beziehungsweise eine politische Repräsentation von Frauen die Einführung von Gender Budgeting (vgl. auch Kapitel 3.2.2.1.1). Politische Repräsentation ist ein Herrschaftsmechanismus, durch den an bestimmte Gruppen Macht übertragen wird und andere marginalisiert werden. In repräsentativen Demokratien sind Frauen sowohl quantitativ als auch substantiell-inhaltlich unterrepräsentiert. Folglich ist für eine geschlechtergerechte und demokratische Öffnung des Budgetprozesses die Frage der Repräsentation ein wesentlicher demokratiepolitischer Faktor sowie eine Steigerung der Partizipationschancen von Frauen innerhalb von repräsentativ-demokratischen Institutionen beziehungsweise eine Steigerung der Parität zwischen Frauen und Männern in der Politik nötig. Dies bedeutet Partizipationshindernisse für Frauen abzubauen und sowohl formalrechtliche Partizipationsmöglichkeiten, wie beispielsweise durch Quoten, als auch die strukturellen Bedingungen für Frauen zur Schaffung besserer Bildungsund Aufstiegsoptionen innerhalb der finanzpolitisch relevanten Institutionen und Prozesse in den Blick zu nehmen. Notwendig für eine demokratische Transformation des Wiener Budgetprozesses ist daher sowohl eine ausreichende quantitative politische Repräsentation von Frauen in allen beteiligten Verfahren und 
Institutionen als auch eine funktionale bzw. Gruppenrepräsentation. Menschen können auf verschiedene Arten in den politischen Institutionen repräsentiert werden: Eine quantitative Repräsentation zeichnet sich dadurch aus, dass die repräsentierende Person Merkmale einer sozialen Gruppe trägt sowie deren Erfahrungen teilt, die Repräsentation beruht auf der Identität und sozialen Zusammensetzung der WählerInnenschaft. Bei der qualitativen Repräsentation vertritt eine Person die Interessen einer Gruppe, die Repräsentation beruht auf Interessen, die RepräsentantInnen agieren als SprecherInnen von Interessensgruppen.

Demgemäß ist hinsichtlich der Frage der quantitativen Repräsentation zu beachten, dass in den beiden Phasen Erstellung des Voranschlagsentwurfes und Feststellung des Voranschlages eine verhältnismäßige Repräsentation von Frauen in jeweiligen Entscheidungsinstitutionen, wie den einzelnen Verwaltungsdienststellen, der MA 5, dem Finanzausschuss ${ }^{50}$, dem Stadtsenat und dem Gemeinderat und den politischen Parteien, beispielsweise durch Quotierung von höchster Bedeutung ist, um existierende Personalrekrutierungsmodelle zu durchbrechen und einen frauenpolitischen Einfluss zu forcieren. Neben Quotierungen wären Frauenförderpläne - wie sie beispielsweise seit dem Jahr 1997 für die Bedienstete der Gemeinde Wien existieren - eine weitere Möglichkeit zur Beseitigung der Unterrepräsentanz von Frauen. Die Frauenförderpläne sind gemäß $\S 38$ des Wiener Gleichbehandlungsgesetzes (W-GBG) von allen acht Geschäftsgruppen sowie der Magistratsdirektion für jeweils sechs Jahre zu erstellen. Sie beinhalten zahlenmäßige Zielvorgaben um den Frauenanteil in den Dienststellen, in denen Frauen unterrepräsentiert sind, sowie in den höherwertigen Posten zu erhöhen (und damit die Aufstiegsmöglichkeiten für Frauen zu verbessern). Weiters wird anhand der Frauenförderpläne festgelegt, in welchem Zeitraum, mit welchen organisatorischen, aus- und weiterbildenden, personellen, baulichen und sonstigen raumschaffenden Maßnahmen bestehende Benachteiligungen und die Unterrepräsentation von Frauen beseitigt werden ( $\$ 38$ Abs. 4 W-GBG). Diese Frauenförderpläne könnten nun zum Beispiel auf alle entscheidungsbefugten Institutionen des Wiener Budgetprozesses ausgedehnt werden.

Jedoch ist dies eine notwendige aber keineswegs hinreichende Bedingung für eine geschlechtergerechtere Repräsentation im Wiener Budgetprozess. Es ist des Weiteren wichtig, auch auf eine Repräsentation unterschiedlicher Frauengruppen zu achten um damit auch eine qualitative Repräsentation von unterschiedlichen Fraueninteressen sicherstellen zu können. Ein mögliches Konzept hierfür wäre, Formen der Gruppenrepräsentation (vgl. Kapitel 4.3.3) zu institutionali-

50 Exemplarisch seien hierzu die Verteilung zwischen Frauen und Männern von $25 \%$ zu $75 \%$ im Finanzausschuss genannt (Stand Dezember 2007) sowie der Frauenanteil von 33\% an den vollzeitbeschäftigten Bediensteten der MA 5. In der MA 5 sind des Weiteren nur 20\% der höherwertigen Posten mit Frauen besetzt (vgl. außerdem zum Frauenanteil der BudgetkoordinatorInnen und Budgetreferentinnen Fußnote 36 auf Seite 76). 
sieren und die dafür notwendigen institutionellen Mechanismen und öffentlichen Ressourcen bereitzustellen. Die Mitglieder der jeweiligen unterdrückten Gruppen sollten in demokratischen Foren zusammentreffen können um zum Beispiel den Voranschlagsentwurf zu diskutieren, Analysen, dazu wie sich die budgetären Maßnahmen auf sie auswirken werden, und Stellungnahmen zu erarbeiten (vgl. dazu auch Kapitel 5.3.1). Innerhalb dieser Gruppenversammlungen werden dann - ähnlich des Prozesses in Porto Alegre - GruppenvertreterInnen delegiert, welche die politischen Vorschläge der Gruppe dann in institutionellen Zusammenhängen (wie in der öffentlichen Sitzung des Gemeinderates zur Feststellung des Voranschlages) einbringen. Die EntscheidungsträgerInnen wären dazu verpflichtet diese Perspektiven in ihre Überlegungen einzubeziehen. AuBerdem könnten in einer solchen Gruppenrepräsentation auch jenen Gruppen ein Vetorecht hinsichtlich bestimmter budgetärer Maßnahmen, die die Gruppe direkt und in besonderer Weise betreffen, eingeräumt werden.

Es muss auch darauf geachtet werden, dass die Differenzen zwischen Frauen wie beispielsweise entlang ihres Alters, ihrer Religion, ihrer ethnische Zugehörigkeit, ihrer sexuelle Orientierung sowie ihrer sozialer und räumlicher Situation nicht durch Mechanismen einseitiger Repräsentation verfestigt werden, sondern vielmehr die Kategorie Frauen problematisiert wird um eine Anerkennung und Repräsentation der Unterschiede zwischen Frauen zu erwirken. Denn ,Frauen' sind keine homogene Gruppe oder monolithische Kategorie und sprechen nicht alle mit einer Stimme. Ihre vielfältigen Differenzen müssen Berücksichtigung finden, ihre Unterschiede wahrgenommen und anerkannt werden. Daher ist nicht nur eine Anerkennung der Geschlechterdifferenz sondern auch eine Anerkennung der Differenzen zwischen Frauen nötig. Dies bedeutet, dass ein Bewusstsein dafür geschaffen werden muss, dass die Bedürfnisse von Frauen hinsichtlich der Verteilung von Ressourcen mit ihren unterschiedlichen Erfahrungen und Hintergründen different definiert werden: So haben Frauen mit Migrationshintergrund andere Bedürfnisse, die im Voranschlag berücksichtigt werden sollen als beispielsweise Rentnerinnen oder Studentinnen.

Abgesehen davon ist des Weiteren - damit formal-rechtliche geschlechtsspezifische Repräsentationshindernisse für Frauen beseitigt werden können - die Frage der Political Leadership und des Empowerment von Frauen wesentlich. Um den Wiener Budgetprozess geschlechtergerecht zu demokratisieren ist es notwendig, dass sowohl auf Ebene der Partizipation wie auch auf Ebene der Repräsentation Aufstiegsmöglichkeiten für Frauen geschaffen werden ${ }^{51}$. Frauen müssen strukturelle Bedingungen vorfinden, die es ihnen ermöglichen, jene Pos-

51 Auch hier möchte ich auf die Frauenförderpläne, die für die Wiener Verwaltung gelten, als einen ersten Schritt in die Richtung Politial Leadership von Frauen verweisen. Eine andere Möglichkeit für Frauen in Führungspositionen zu gelangen, stellen Quoten dar (vgl. dazu weiter oben Repräsentation von Frauen). 
itionen zu bekleiden, die in der Phase der Erstellung und Feststellung des Voranschlages Einfluss auf die politische Willensbildung und Entscheidungsfindung haben und die ihnen dadurch finanzpolitische Entscheidungs- und Definitionsmacht einräumen. Voraussetzung für eine solche Übernahme von Führungspositionen ist Empowerment von Frauen durch Zugang zu Informationen sowie durch eine Ressourcenumverteilung. Gerade das Fehlen von Informationen zu spezifisch finanzpolitischen Themen, das zum einen zwar vom Bildungsniveau zum anderen jedoch zum größten Teil von institutionellen Verfahren beeinflusst wird, ist für die geringe formal-rechtliche Partizipation von Frauen im Budgetprozess verantwortlich.

Empowerment beziehungsweise die Ermächtigung von Frauen ist auch eine Gender Budgeting inhärente Forderung: Gender Budgets sollten zum Ziel haben zum persönlichen, rechtlichen, politischen, kulturellen, sozialen und ökonomischen Empowerment von Frauen beizutragen. Denn sie können das Selbstbewusstsein, Selbstwertgefühl sowie die Selbstsicherheit von Frauen stärken (,power from within"), indem öffentliche Ressourcen für geschlechtergerechte Politiken aufgewendet werden. Damit erhalten Frauen die Möglichkeit zu lernen und eigene Lösungsvorschläge für ihre Probleme zu entwickeln (,power to"). Außerdem sollen Gender Budget-Initiativen dazu beitragen, dass sich Frauen mit anderen organisieren, zusammenschließen und gemeinsam für ihre Anliegen und Bedürfnisse eintreten (,,power with"), was wiederum zu einer Machterweiterung von Frauen führt (,power over") und Frauen so bislang Männern vorbehaltene Gebiete wie die der Wirtschafts- und Finanzpolitik erschließen können (vgl. Bergmann et al 2004: 13). Dies bedeutet für den Wiener (Gender) Budgetprozess eine weitere zentrale inhaltliche Erweiterung, denn mittels einer geschlechtergerechten Finanzpolitik sollten Voraussetzungen und Politiken geschaffen werden, die Frauen eine autonome Wahl für ihre Lebensgestaltung ermöglichen.

Des Weiteren sind in mehrfacher Hinsicht die beiden miteinander verwobenen Kategorien Öffentlichkeit und Deliberation für die Phasen Erstellung des Voranschlagsentwurfes und Feststellung des Voranschlages des Wiener Budgetkreislaufes zentral. Erstens ist zu beachten, dass auch die Wiener Finanzpolitik Auswirkungen auf die Privatsphäre hat und daher zu gewährleisten ist, dass Privatheit als eine zentrale und notwendige Voraussetzung und Bedingung für eine demokratische Öffentlichkeit zu konzeptualisieren ist, die kein der Öffentlichkeit entgegen gesetzter Bereich ist, sondern vielmehr diejenigen Beziehungsmuster umfasst, die dem öffentlichen Diskurs entzogen sind. Außerdem ist zu berücksichtigen, dass mit der Unterscheidung von Privatheit und Öffentlichkeit geschlechterspezifische Konnotationen verbunden sind, die durch die Verteilung öffentlicher Ressourcen fort- und festgeschrieben werden. Die Akteurinnen und Akteure der Phasen Erstellung und Feststellung des Voranschlages müssen die- 
ses Dilemma beachten, die Wichtigkeit von Privatheit für die politische Öffentlichkeit respektieren, aber zugleich einer geschlechtsspezifischen beziehungsweise geschlechterideologischen Festschreibung von öffentlich und privat sowie einer resultierenden politischen Ausgrenzung von Frauen entgegenarbeiten. Zweitens ist der Budgetprozess als ein öffentlicher Entscheidungsprozess beziehungsweise öffentlicher Diskurs zu konzipieren, in dem um Interessen-Hegemonie und feministische Gegendiskurse beziehungsweise Feminisierung von Öffentlichkeit gerungen werden muss, in dem Macht und Herrschaft thematisiert und kritisiert sowie Möglichkeiten politischen Handelns gegeben werden sollen. Drittens muss aus einer feministischen deliberativ-demokratischen Perspektive ein geschlechtersensibles Modell einer kommunikativen Demokratie geschaffen werden, welches sich durch universalistische Prinzipien wie die Inklusion von allen Betroffenen in den Entscheidungsfindungsprozess sowie den gleichen $\mathrm{Zu}$ gang für alle Betroffenen, durch politische Gleichheit, durch die Bereitschaft zur vernünftigen Lösung kollektiver Probleme und durch Pluralität und Differenz von in ihnen kommunizierenden Menschen auszeichnet. Um diese Aspekte zu realisieren, müssen aktiv Foren öffentlicher Debatte geschaffen werden, in denen feministische Akteurinnen den Voranschlagsentwurf kritisieren und Alternativentwürfe vorstellen können (vgl. auch Kapitel 5.3.1). Die zentralen Elemente in diesen öffentlichen Diskussionen sind Argumentieren und Zuhören. Debatten bestehen jedoch nicht nur aus Sprechakten also ihrem substantiellen Gehalt sondern auch aus dem wie etwas gesagt wird. Daher müssen auch die verschiedenen Varianten wie etwas gesagt werden kann um Inhalte zu formen und zu färben, wie beispielsweise Emotionalität, Gestik und Mimik, in Betracht gezogen werden. Ein geschlechtersensibles kommunikatives Demokratieverständnis könnte demokratische Diskussionen erweitern sowie die Art und Weise Probleme und mögliche Lösungen zu erkennen verändern.

\subsubsection{Institutionelle und outputorientierte feministisch-demokratische Bedingungen für die Phase der Vollziehung des Voranschlages}

Für eine geschlechtergerechte Transformation und Demokratisierung des Wiener Budgetprozesses sind in der Phase der Vollziehung des Voranschlages neben den fünf in Kapitel 5.3.1 herausgearbeiteten generellen Inputkriterien drei weitere, zwei institutionelle Prinzipien sowie ein outputorientiertes Kriterium wesentlich (vgl. Abbildung 14).

Denn Demokratisierung bedeutet neben der Aufhebung von Ungleichheiten in der politischen Entscheidungskompetenz auch die Verringerung von Machtdifferentialen, indem finanzpolitische Entscheidungen mit Gerechtigkeitsüberlegungen angereichert und im Speziellen Geschlechtergerechtigkeitsüberlegungen in den Mittelpunkt gerückt werden müssen. 
Abbildung 14: Prinzipien für die Phase des Voranschlagvollzuges

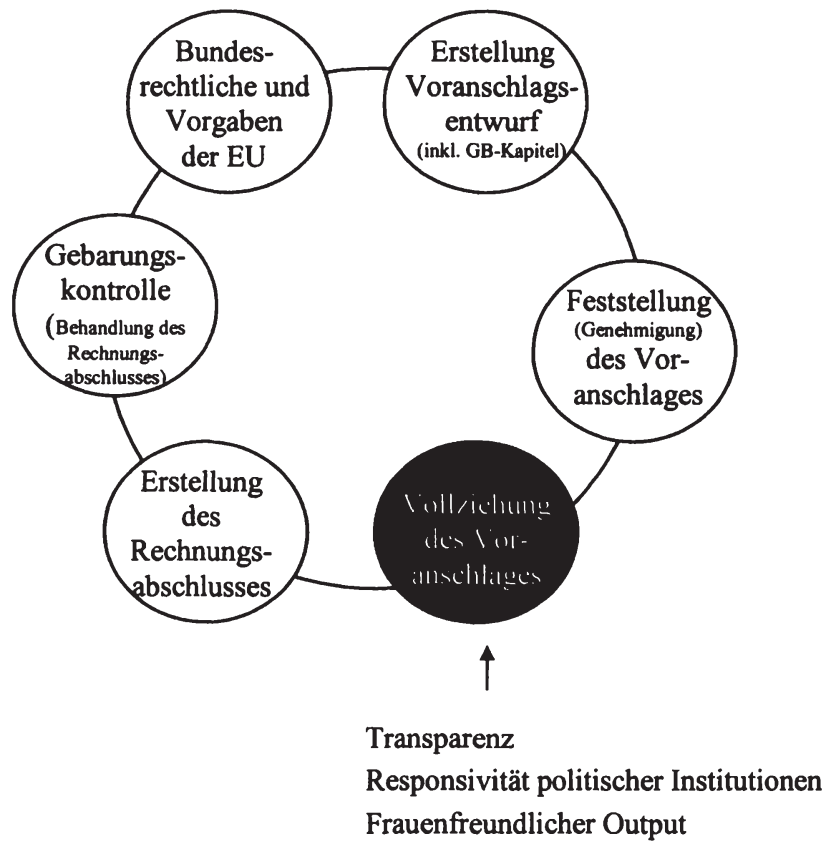

Quelle: eigene Darstellung

Neben dem Argument für eine möglichst weitgehende Partizipation von Frauen findet sich in der Gender Budgeting-Literatur als die zweite große Forderung diejenige nach Transparenz beziehungsweise nach Erreichung eines transparenten Budgetprozesses. Transparenz beschreibt hierbei die Durchsichtigkeit und Zugänglichkeit von finanzpolitischen Entscheidungswegen, der Budgetprozess braucht Verstehbarkeit, Transparenz und Zugänglichkeit der politischen Entscheidungsverfahren.

Mögliche Ansatzpunkte für mehr Transparenz im Budgetprozess könnten einerseits die Verpflichtung der mit der Voranschlagsvollziehung betrauten Akteurinnen und Akteure zur regelmäßigen Information sowie andererseits die Institutionalisierung von Feedback-Schleifen sein. Diese Feedback-Schleifen stellen eine Möglichkeit dar um umsetzende Akteurinnen und Akteure zu kritisieren und zur Verantwortung ziehen zu können. Durch größere Transparenz in der Phase des Voranschlagvollzugs kann sichtbar gemacht werden, wo Lücken in der Umsetzung von Gender Budgeting bestehen beziehungsweise das Einfließen von Geschlechtergerechtigkeitsüberlegungen in den Voranschlag und dessen 
Implementierung kontrolliert werden und, wenn nötig, Korrekturmöglichkeiten und -instanzen institutionalisiert werden.

Dies führt zu dem Erfordernis, dass Informationen über den Budgetprozess, über die dem Budgetprozess im Speziellen der Voranschlagsvollziehung zugrunde liegenden Daten sowie Dokumente über die Zuständigkeiten des Vollzuges des Voranschlages frei zugänglich sein müssen beziehungsweise die entscheidungsbeteiligten Institutionen verpflichtet werden müssen, Informationen öffentlich zur Verfügung zu stellen. Dies geschieht im Wiener Budgetprozess zu einem gewissen Teil insofern als dass der Voranschlag nach Genehmigung im Internet veröffentlicht wird und die jeweiligen Zuständigkeitsbestimmungen der Befugnis zur Anordnung von Einnahmen und Ausgaben in der Wiener Stadtverfassung öffentlich zugänglich sind.

Die Zugänglichkeit zu Informationen bedarf jedoch auch einer adäquaten und verständlichen Aufbereitung ebendieser. Dies bedeutet, dass budgetrelevante Daten so formuliert und in einer allgemein verständlichen Form präsentiert werden. „Economic Literacy“ beziehungsweise Wirtschaftsalphabetisierung, also die Fähigkeit ökonomische, wirtschafts- und finanzpolitische Materialen und Informationen zu verstehen und kritisch zu erfassen ist in diesem Zusammenhang eine Qualifikation, die auf einer breiten Basis vermittelt werden sollte um auf Basis dessen ,gegen sonst oft undurchschaubare ökonomische Entscheidungen auftreten zu können" (Bergmann et al 2004: 76). Mittels (öffentlich finanzierter) Seminare und Workshops könnten Frauen beispielsweise über das Wiener Budget sowie den Wiener Budgetprozess informiert, ermutigt und inhaltlich bei einer gemeinsamen Erarbeitung von Wissen über wirtschaftliche Zusammenhänge unterstützt werden (vgl. auch Kapitel 5.3.2).

Ein weiteres wichtiges feministisch-demokratisches Prinzip im Voranschlagsvollzug ist die Responsivität politischer Institutionen, also die Responsivität jener Institutionen, welche mit dem Vollzug betraut sind. Frauenpolitische Responsivität bedeutet gezielte Bearbeitung von Frauenthemen, Verantwortlichkeit von Regierungen und politischen Institutionen für Frauen- beziehungsweise Geschlechterfragen und dass frauenpolitische Anregungen zu hörbaren Argumenten im öffentlichen Diskurs werden. Hierbei ist zunächst von Bedeutung, dass die budgetpolitischen Alternativvorschläge frauenpolitischer Akteurinnen und Akteure als wirkliche Alternativen von den EntscheidungsträgerInnen ernst genommen werden. Daher muss die Responsivität von Verwaltung und Gemeinderat hinsichtlich frauenpolitischer Impulse beispielsweise durch Schulungen erhöht werden. Außerdem müssen im Zuge von Gender Budgeting Frauen- und Geschlechterfragen auch in der Voranschlagsvollziehung systematisch Einzug finden und bearbeitet werden. Ein geschlechtergerechter Vollzug des Voranschlages hängt wesentlich von den beteiligten Akteurinnen, Akteuren und Institutionen ab, daher muss gewährleistet werden, dass die Handlungsspiel- 
räume frauenfreundlich genutzt werden und der Ungleichstellung von Männern und Frauen entgegengewirkt wird.

Ein möglicher Ansatzpunkt für eine Umsetzung in diesem Sinne ist zum Beispiel der Einsatz von GenderexpertInnen in der Bürokratie oder das Bereitstellen von Kriterienkatalogen für eine geschlechtergerechte Implementierung. Beides könnte im Wiener Budgetprozess zumindest zu einem Teil von der Gender Mainstreaming Projektstelle, die intensiv mit den Gender Budgeting-Beauftragten zusammenarbeitet (vgl. Kapitel 3.2.2.1.1), übernommen werden.

Eine geschlechtergerechte und emanzipatorische Demokratisierung des Budgetprozesses kann in erster Linie durch einen frauenfreundlichen Output der Politiken beim Vollzug des Voranschlages sichtbar werden. Eine frauenfreundliche ebenso wie die Unterschiede zwischen Frauen anerkennende Politik kann dann als solche bezeichnet werden, wenn sie ideale, geschlechtergerechte sowie feministische Politiken implementiert, die Frauen empowern und sie von Unterdrückung und Herrschaft befreien. Frauenfreundlichkeit kann anhand der Verpflichtung, alle Frauen fair zu behandeln und der Anstrengungen frauendiskriminierende Gesetze und Politiken zu beseitigen, gemessen werden.

Ein frauenfreundlicher Output des Voranschlages sollte bei der Verteilung von Ressourcen an mehreren Punkten ansetzen: Erstens muss gewährleistet werden, dass die Autonomie aller Frauen unabhängig von ihrer Klasse, Ethnie, Religion oder ihrem Alter gefördert wird. Um die vollständige politische Partizipation von Frauen zu ermöglichen, bedarf es der materiellen Absicherung von Frauen. Da die Teilnahme an demokratischen Prozessen bestimmte Ressourcen wie Zeit, Geld, Bildung und Einflussmöglichkeiten braucht, muss der Ausbeutung, der wirtschaftlichen Marginalisierung und Deprivation von Frauen durch Umverteilung entgegengesteuert werden. Ein frauenfreundlicher Budgetoutput muss daher durch eine geschlechtergerechte Umverteilung der individuellen Benachteiligung von Frauen entgegenwirken. Zweitens muss ein frauenfreundlicher Output bei gesellschaftlichen Strukturen, Institutionen und Prozessen, die Geschlechterungerechtigkeiten und Geschlechterungleichheiten reproduzieren, wie beispielsweise der geschlechtsspezifischen Arbeitsteilung, ansetzen und diesen entgegenwirken.

Da die grundlegenden Ziele von Gender Budgeting die Geschlechtergerechtigkeit und die soziale und politische Gleichstellung von Frauen und Männern sind, wäre für den Wiener Budgetprozess in einem ersten Schritt eine grundsätzliche, nach innen und nach außen erkennbare politische Zielsetzung, die mit Gender Budgeting erreicht werden soll, nötig. Eine Forcierung von Gleichstellung und Geschlechtergerechtigkeit könnte beispielsweise anhand von allgemeinen Gleichstellungszielen, die für alle Politikbereiche gleichermaßen gültig sind, konkretisiert werden. Solche Gleichstellungsziele wurden für die Gender Budget-Analyse in Oberösterreich, abgeleitet aus sozialen, bürgerlichen und wirt- 
schaftlichen Menschenrechten, formuliert und sollen hier beispielhaft angeführt werden (vgl. Klatzer 2004: 28, Schratzenstaller et al 2006: 10):

- Gleiche Möglichkeiten für Frauen und Männer zu ökonomischer Unabhängigkeit durch Erwerbsarbeit.

- Eigenständige soziale Absicherung in allen Lebensphasen (insbesondere Elternschaft, Kinderbetreuung und -erziehung, Bildung, Arbeitslosigkeit, Pflege, Krankheit, Alter) für Frauen und Männer.

- Autonomie über die eigene Zeitverwendung für Frauen und Männer.

- Selbstbestimmte Lebensgestaltung für Frauen und Männer.

- Gleiche Möglichkeiten für Frauen und Männer zur Entwicklung ihrer persönlichen Fähigkeiten und Potenziale.

- Gleiche Teilhabemöglichkeiten (ökonomische, gesellschaftliche und politische Partizipation) für Frauen und Männer.

- Gleiche Verteilung von Macht und Einfluss für Frauen und Männern hinsichtlich politischer und ökonomischer Entscheidungen und Prozesse.

- Leben frei von jeder Form von Gewalt für Frauen und Männer.

- Gleicher Zugang zu öffentlichen Leistungen für Frauen und Männer.

Diese Gleichstellungsziele können als Vorschläge herangezogen werden, es bleibt jedoch die Aufgabe der demokratischen öffentlich-deliberativen, formalrechtlichen und politischen Institutionen die konkret zu verfolgenden Gleichstellungsziele zu diskutieren, auszuwählen und Prioritäten zu setzen. Dies würde jedoch auch bedeuten, dass gleichstellungspolitische Ziele jeweils für die einzelnen Phasen des Budgetkreislaufes bereits zu Beginn des Budgetprozesses definiert werden müssen und im Zuge einer Evaluierung dann hinsichtlich ihrer Erfüllung geprüft und kontrolliert werden sollten. Denn nur so kann gewährleistet werden, dass Gleichstellungsziele umgesetzt, die Wirkungen bestimmter Maßnahmen auf die Geschlechterverhältnisse herausgefunden und eventuelle Korrekturen im Budgetprozess vorgenommen werden können.

\subsubsection{Institutionelle feministisch-demokratische Bedingung in der Phase Gebarungskontrolle}

Soll der Wiener Budgetprozess geschlechtergerecht und frauenfreundlich demokratisiert werden, so müssen auch die Kontroll- und Eingriffsmöglichkeiten in die finanzpolitischen Entscheidungsprozesse verstärkt werden. Dies erweist sich vor allem in der Phase der Gebarungskontrolle und Überprüfung der Haushaltsführung der Gemeinde Wien besonders relevant (vgl. Abbildung 15). Rechenschaftspflicht bedeutet in diesem Zusammenhang - wie in Kapitel 4.3.8 heraus- 
gearbeitet - nicht den Ausschluss von Partizipation. Demgemäß gelten in dieser Phase auch weiterhin die allgemeinen fünf Inputkriterien (vgl. Kapitel 5.3.1).

Abbildung 15: Kriterienkomplex der Kontrolle für die Phase Gebarungskontrolle

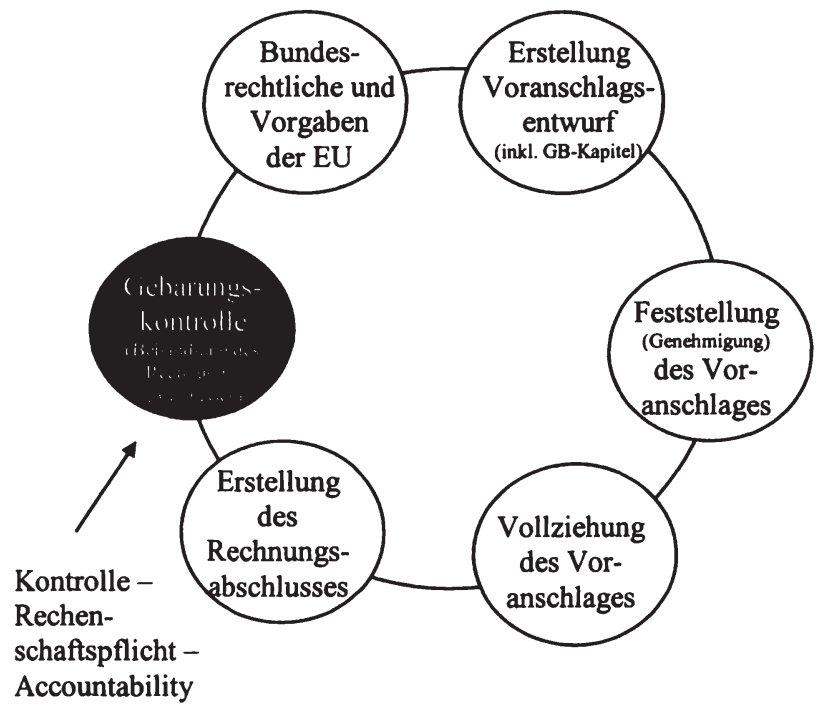

Quelle: eigene Darstellung

Die Gender Budgeting-Literatur unterstreicht, dass Budgetprozesse partizipativ (so dass jede/r BürgerIn die gleiche Stimme hat), transparent und ,accountable“ gestaltet werden müssen. Gemeinsames Ziel von Gender Budget-Initiativen ist die Accountability gegenüber Frauen und Gleichstellungszielen beziehungsweise -anstrengungen zu verbessern und ihnen demgemäß größeres Gewicht in Entscheidungsprozessen zu verleihen. Gender Budgeting soll Transparenz, Partizipation, Accountability und Geschlechtergleichstellung erwirken beziehungsweise geschlechtsspezifische Ungleichheiten reduzieren (vgl. u.a. Elson 2004: 16). „Accountable“ bedeutet hierbei rechenschaftspflichtig den Bürgerinnen und Bürgern gegenüber. Legitimierte RepräsentantInnen sind solche, die denjenigen die sie repräsentieren rechenschaftspflichtig sind. Repräsentierende sind verantwortlich für ihre Entscheidungen und Mandate und sollen angehalten sein, den zu Repräsentierenden zu zuhören, deren Kritik, Anforderungen und Forderungen in ihre Arbeit aufzunehmen und zuerst in Politiken und dann in die Praxis zu übersetzen. 
Dementsprechend müssen in den Wiener Budgetprozess Prinzipien der Kontrolle, Rechenschaftspflicht und Accountability eingeführt werden. Dies bedeutet zweierlei: Zum einen muss in der Phase der Gebarungskontrolle klar sein, welche Akteurinnen und Akteure für welche Entscheidungen verantwortlich waren und sind. Auch hier sollen alle das Recht auf und den Zugang zu den gleichen Informationen bekommen. Zum anderen müssen im Kontrollprozess selbst Prinzipien der Qualität und Zurechenbarkeit der Bewertungen gewährleistet werden: Die Akteurinnen und Akteure der Phase der Gebarungskontrolle müssen für ihre Entscheidungen und Bewertungen verantwortlich gemacht werden können, auch in dieser Phase müssen bestimmte Kontroll- und Eingriffsmöglichkeiten gewährleistet sein und das Prinzip der Rechenschaftspflicht institutionalisiert werden. Daher ist eine Kontrolle auf institutioneller Ebene durch das Kontrollamt und den Rechnungshof zwar eine durchaus notwendige, dennoch noch keine hinreichende Instanz. Über diese institutionelle Ebene hinaus könnten auch in der Phase der Gebarungskontrolle Diskussionsforen angedacht werden, in denen der bisherige Budgetprozess evaluiert und Impulse für weitere geschlechtergerechte und emanzipatorische Maßnahmen erarbeitet werden.

Außerdem sollten sowohl Gemeinderat, Kontrollamt und Rechnungshof das Budget sowie den Budgetprozess auch geschlechterkritisch prüfen beziehungsweise ihre Prüfungskriterien gegebenenfalls um geschlechtergerechte Kriterien erweitern. Der österreichische Rechnungshof hat die Chancengerechtigkeit von Männern und Frauen zumindest in seinem Leitbild und in seinem Strategiepapier $^{52}$ verankert.

Rechnungshof und Kontrollamt prüfen die Ordnungsgemäßheit, Sparsamkeit, Wirtschaftlichkeit und Zweckmäßigkeit der Haushaltsführung der Gemeinde Wien. Auch diese Konzepte sowie dabei verwendete Indikatoren und Maßzahlen sind oft genderblind. Hiermit stellen sich wiederum mehrfache neue Herausforderungen hinsichtlich einer Neuinterpretation beziehungsweise Rekonzeptualisierung dieser Konzepte und Grundsätze aus der Geschlechterperspektive um geschlechtergerechten und emanzipatorischen Ansprüchen Rechnung tragen zu können.

52 Dokumente unter http://www.rechnungshof.gv.at/uploads/media/Leitbild_02.pdf und http: //www.rechnungshof .gv.at/uploads/media/Strategie_01.pdf abrufbar 
Katharina Mader - 978-3-631-75378-1

Downloaded from PubFactory at 01/11/2019 05:43:12AM

via free access 


\section{Fazit und weiterer Forschungsbedarf}

Die Erwartungen an das emanzipatorische Potential von Gender Budgeting und das damit verbundene Anliegen die Finanz- und Wirtschaftspolitik zu demokratisieren, partizipativer und transparenter zu gestalten sind groß. Ebenso groß ist jedoch die Kluft zwischen dem partizipativen Anspruch von Gender Budgeting per definitionem und der Umsetzung von Gender Budget-Initiativen in der Praxis. Auch die bis dato fehlende wissenschaftlich-theoretische Präzisierung und Fundierung von Demokratisierung im Zusammenhang mit Gender Budgeting wirkt auf die Gestaltung der demokratischen Praxis von Gender Budget-Initiativen und verstärkt die bestehende Kluft.

Während beispielsweise das Partizipative Budget in Porto Alegre als ein gelungenes Beispiel für die Demokratisierung der Wirtschaftspolitik genannt wird, konnten Gender Budget-Inititativen - im Speziellen die Wiener Initiative (vgl. Kapitel 3.2.2.1) - die grundsätzlichen Anforderungen, Ansprüche und Rollen, die an Gender Budgeting gestellt werden, (noch) nicht erfüllen. Daher stellte sich mir im Zuge der Arbeit an dieser Dissertation die Frage, ob - wenn eine Demokratisierung von Finanz- und Wirtschaftspolitik angestrebt wird - Gender Budgeting nicht zu Gunsten eines Partizipativen Budgets nach dem Vorbild Porto Alegres aufgegeben werden könnte.

Doch das Partizipative Budget in Porto Alegre erweist sich als geschlechterblind, eine Partizipation von Frauen und Männern am Budget erwirkt nicht automatisch geschlechtergerechte Partizipationsmöglichkeiten oder politische Outputs, wie eine geschlechtergerechtere Verteilung der Ausgaben. Auch wenn das Partizipative Budget Elemente enthält, die potentiell zu Geschlechtergerechtigkeit beitragen könnten, so bleiben doch die Geschlechterungerechtigkeiten, die auch den traditionellen Budgetprozess charakterisieren, wie die Ignoranz gegenüber unbezahlter von Frauen geleisteter Arbeit, bestehen. Das Partizipative Budget ist zwar kein Exklusionsmodell, das Frauen aus dem Budgetprozess ausschließt, ein Inklusionsmodell ist es jedoch auch nicht.

Hier setzen Gender Budget-Initiativen an und fokussieren auf die Partizipation von Frauen im Budgetprozess und fordern eine systematische Einbeziehung der Geschlechterperspektive in die Finanz- und Wirtschaftspolitik. Wenn also eine geschlechtergerechte und emanzipatorische Demokratisierung von Finanz- und Wirtschaftspolitik angestrebt wird, ist das Partizipative Budget nach Vorbild Porto Alegres zwar nützlich, jedoch nicht hinreichend. Daher sollten Gender Budget-Initiativen keinesfalls zugunsten eines Partizipativen Budgets aufgegeben werden, denn damit gehen deren grundlegende feministische, geschlechtergerechte und emanzipatorische Ansprüche verloren, die jedenfalls über die Ansprüche des PB hinausgehen. Vielmehr wäre ein substantieller, partizipativer 
Ansatz in Gender Budget-Initiativen einzubauen und von den Erfahrungen der PB-Initiativen zu lernen.

Damit Gender Budgeting der Forderung nach einer geschlechtergerechten Demokratisierung von Finanz- und Wirtschaftspolitik gerecht werden und ein emanzipatorisches, demokratie- finanz- und wirtschaftspolitisches Instrument sein kann, braucht es demgemäß theoretische Fundierungen um das demokratische und emanzipatorische Potential von Gender Budgeting zu stärken.

Gender Budgeting soll kein technokratisches Instrument sein, anhand dessen sich ExpertInnen stellvertretend für alle Frauen mit dem Budget beschäftigen. Es soll auch nicht zu einem Beschäftigungsprogramm für die Verwaltung oder Forschung werden. Auch eine erste Gender-Sensibilisierung beziehungsweise Gender-Wissensvermittlung der Verwaltung - wie sie in Wien im Speziellen für die FinanzexpertInnen stattfand oder eine verstärkte Erstellung geschlechtersensibler Statistiken sind zwar ein erster Schritt, entsprechen jedoch noch nicht den theoretischen Ansprüchen und Anforderungen von Gender Budgeting. Damit die Wiener Gender Budget-Initiative nicht weiterhin relativ wirkungslos und ohne Veränderungen der Budgetprioritäten bleibt, benötigt die Gender Budget-Initiative sowohl prozesstechnisch-demokratische wie auch inhaltliche Rahmenbedingungen, die von den gegenwärtigen Budgetentscheidungen und -prozessen abweichen.

Da die feministische Politikwissenschaft über eine lange und umfassende Auseinandersetzung mit Demokratie, Demokratisierung sowie demokratischen Modellen, deren Chancen und Probleme bezüglich der Partizipation von Frauen verfügt, habe ich für die Präzisierung eines Demokratiekonzepts und -verständnisses für Gender Budgeting die zentralen Begrifflichkeiten und Konzepte der feministischen demokratietheoretischen Debatte systematisch untersucht. Die Auseinandersetzung mit feministischen Demokratiekonzeptionen hat gezeigt, dass es die eine feministische Demokratietheorie nicht gibt, daher habe ich die gemeinsamen zentralen Inhalte, Dimensionen und Konzepte feministischer Demokratietheoretikerinnen identifiziert und daraus einen Kriterienkatalog als Modell von feministisch-demokratischen Prinzipien entwickelt. Dieser Kriterienkatalog zeigt eine normative Alternative zum vorherrschenden Modell der Finanzpolitik und des Budgetprozesses auf.

Im Zuge einer Integration dieser Kriterien in den Budgetprozess habe ich anschließend eine geschlechtergerechte demokratische Erweiterung des Wiener Budgetprozesses skizziert und die feministischen Demokratisierungsimpulse auf inhaltlicher, institutioneller und prozessualer Ebene eingearbeitet. Anhand dieser Zusammenführung der Demokratiekategorien mit dem Budgetprozess ist sichtbar geworden, dass es die eine Patentlösung für „den“ geschlechterdemokratischen Budgetkreislauf nicht gibt, sondern dass eine geschlechtergerechtere Demokratisierung des Budgetprozesses bedeutet, dass dieser immer wieder neu 
verhandelt werden muss und dass möglichst viele unterschiedliche Frauen(-interessen) die Möglichkeit erhalten, an diesem Aushandlungsprozess teilnehmen zu können und ihre Bedürfnisse, ihre Perspektiven sowie ihre Betroffenheiten in den finanzpolitischen Entscheidungsfindungsprozess einzubringen.

Die Integration der feministisch-demokratischen Kriterien kann in den einzelnen Phasen des Budgetkreislaufes Demokratisierungsimpulse und -anreize bieten, aufgrund derer Frauen einerseits die Chance bekommen am Budgetprozess teilzunehmen und andererseits die, in den Budgetprozess eingelassenen, Geschlechterverhältnisse und -ungerechtigkeiten aufgebrochen werden können und einer Reproduktion von sozialen Ungleichheiten entgegen gewirkt werden kann. Darüber hinaus sollen sie außerdem die Möglichkeit eines tiefergreifenden strukturellen und substantiellen Wandels eröffnen.

Aus den Ausführungen in Kapitel 5 ist deutlich geworden, dass es für eine weitgehendere geschlechtergerechte demokratische Transformation zentral ist, den Budgetprozess als umfassenden Kreislauf zu verstehen. Dieser beginnt nicht wie im Allgemeinen dargestellt wird, mit der Erstellung des Budgetentwurfs, sondern mit der vorgelagerten Phase der bundesrechtlichen und Vorgaben der EU (vgl. Abbildung 10).

Diese Phase ist insofern bedeutend als die Rahmenbedingungen und Strategien der EU beziehungsweise des Bundes den Handlungsspielraum der Finanz- und Wirtschaftspolitik auf kommunaler Ebene massiv beeinflussen, sich dort spezifische Interessenkonstellationen herausbilden, entschieden wird welche bestimmten Interessen als allgemeine festgesetzt werden und wie diese in der Ressourcenverteilungen gesellschaftlich wirksam werden. So wird auch die Durchsetzung von Zielen der Geschlechtergerechtigkeit auf kommunaler Ebene von diesen Rahmenbedingungen beeinflusst, wodurch Gender Budgeting und damit verbunden eine geschlechtergerechte demokratische Transformation von Budgetprozessen um diese Aspekte erweitert werden muss. Anderenfalls besteht die Gefahr dass die Vorgaben des Bundes und der EU als unveränderbar und unverhandelbar hingenommen werden. Für einen geschlechtergerechteren und demokratischeren Budgetprozess ist es daher wichtig, diese Phasen als Teil des Budgetprozess zu begreifen, die in diesen Phasen negierten (Frauen-)Interessen sichtbar zu machen und in einem weiteren Schritt Strukturen und Mechanismen zu schaffen um diese Interessen als politisch wichtig anzuerkennen und ihnen im weiteren Budgetprozess auch Rechnung zu tragen.

Während die in Kapitel 5.3 angedachten Konzepte und Prinzipien zwar auf den Wiener Budgetprozess zugeschnitten sind, sollte sich Gender Budgeting als Strategie zur emanzipatorischen und geschlechtergerechten Gestaltung der Finanzpolitik in der dargestellten Form nicht auf das Gemeindebudget der Stadt Wien beschränken. Ähnlich könnte der Katalog der feministisch-demokratischen Kriterien auch auf andere finanzpolitische Umfelder angewandt werden und so 
beispielsweise im EU-Budgetprozess oder im Budgetprozess des Bundes jeweils genauer ausgestaltet werden.

Weiterer Forschungsbedarf ergibt sich für mich außerdem speziell in Wien. Hier sollten auch die Budgetprozesse auf der Ebene der Bezirke geschlechtergerecht transformiert werden. Denn im Zuge verstärkter Dezentralisierungsbestrebungen wurde die Verwaltung von Haushaltsmitteln für bestimmte Aufgabenbereiche in die Kompetenz der Organe der einzelnen Bezirke (Bezirksvertretung, Finanzausschuss der Bezirksvertretung und BezirksvorsteherIn) gelegt. Zu den Angelegenheiten in denen die Haushaltsmittel von den Bezirken verwaltet werden zählen insbesondere lokale Angelegenheiten wie die Instandhaltung von städtischen Kindertagesheimen, Pflichtschulen, der öffentlichen Beleuchtung, der Märkte sowie Amtsgebäude. Außerdem gehören die Errichtung und die Instandhaltung von Haupt- und Nebenstraßen sowie deren Verkehrsleiteinrichtungen ebenso wie die Errichtung und Instandhaltung von Grünanlagen oder die Führung von PensionistInnenklubs zu den Aufgaben der Bezirke. Die Mittel hierfür werden den Bezirken jährlich aus dem Voranschlag der Gemeinde Wien auf Basis ihrer EinwohnerInnenzahl, der Fläche der von der Stadt Wien erhaltenen öffentlichen Verkehrsflächen, der SchülerInnenzahl an den von der Stadt Wien erhaltenen Volks-, Haupt- und Sonderschulen, der Zahl der Arbeitsstätten und der Bevölkerungsdichte sowie einer Reihe von weiteren Parametern zur Verfügung gestellt. Der Budgetprozess der Bezirke ist eng angelehnt an den Wiener Budgetprozess, sowie mit ihm verwoben ( $\S 103 \mathrm{f}$ WStV). Daher würden sich sehr ähnliche Anknüpfungspunkte und Konzepte einer geschlechtergerechten Demokratisierung dieses Prozesses ergeben wie die in Kapitel 5.3 erarbeiteten.

Auch für eine konkretere Ausgestaltung der demokratietheoretischen Kriterien im Wiener Budgetprozess selbst sind noch weitere Forschungsarbeiten notwendig. Es bedarf erstens einer weiteren Erforschung der institutionellen Umsetzungsmöglichkeiten der dargelegten feministisch-demokratischen Überlegungen. Damit verbunden ist zweitens auch die Notwendigkeit einer verstärkten Verbindung zwischen der Gender Budgeting-Theorie und Praxis, um die entwickelten Umsetzungsansätze für Gender Budget-Initiativen - im Speziellen die Wiener Initiative - in der Praxis nutzbar zu machen. Außerdem erfordert dies drittens eine eingehendere sozialwissenschaftliche Untersuchung von Budgetprozessen, denn während zwar die institutionellen, prozessualen und gesetzlichen Rahmenbedingungen des Wiener Budgetprozesses bekannt sind, bleiben die Akteurinnen und Akteure, die im derzeitigen Budgetkreislauf tatsächlich ihren Einfluss geltend machen können, kaum erforscht. Dasselbe gilt für die Finanzpolitik beziehungsweise die finanzpolitischen Verflechtungen im Mehrebenensystem (EU, Bund, Länder, Gemeinden). Um die Einflussmöglichkeiten von Frauen in der Finanzpolitik noch weiter ausloten zu können, müssten die vielfältigen formellen, vor allem aber informellen finanzpolitischen Netzwerke so- 
wie Entscheidungsverfahren und -strukturen stärker daraufhin untersucht werden, inwiefern und durch welche Mechanismen Frauen ausgeschlossen werden beziehungsweise wo und in welchen Bereichen frauenpolitische Akteurinnen und Gruppierungen Einfluss erhalten. Solche Forschungsarbeiten wären nicht nur für eine weitere Konkretisierung der institutionellen Möglichkeiten für eine Umsetzung der feministisch-demokratischen Kriterien wichtig, sondern auch eine Bedingung dafür, den Kriterien wie Transparenz, Rechenschaftspflicht, Kontrolle und Partizipation sowie Repräsentation von Frauen gerecht zu werden. 
Katharina Mader - 978-3-631-75378-1

Downloaded from PubFactory at 01/11/2019 05:43:12AM

via free access 


\section{Literatur}

Abels Gabriele /Sifft Stefanie (1999) (Hg.): Demokratie als Projekt. Feministische Kritik an der Universalisierung einer Herrschaftsform. Frankfurt am Main: Campus Verlag.

Abers, Rebecca Neaera (1998): Practicing Radical Democracy. Lessons from Brazil, Paper presented at the Workshop: Insurgent Planning Practices Perugia, Italy, June 21-27, 1998. In: http://www.budget-participatif.org/extranet/ php3/affiche.php3?id=145, abgerufen am 4.5.2007

Abers, Rebecca Neaera (2000): Inventing Local Democracy. Grassroots Politics in Brazil. Colorado: Lynne Rienner Publishers.

Abromeit, Heidrun (2002): Wozu braucht man Demokratie? Die postnationale Herausforderung der Demokratietheorie. Opladen: Leske \& Budrich.

Ahrns, Hans-Jürgen/ Feser, Hand-Dieter (1997): Wirtschaftspolitik. Problemorientierte Einführung. 7. Auflage, München: Oldenbourg Verlag.

Alemann, Ulrich v. (1975): Einleitung: Partizipation, Demokratisierung, Mitbestimmung - Zur Problematik eines Gegenstandes. In: Studiengruppe Partizipationsforschung (Hg.): Partizipation - Demokratisierung - Mitbestimmung. Problemstellung und Literatur in Politik, Wirtschaft, Bildung und Wissenschaft. Eine Einfuihrung. Opladen: Westdeutscher Verlag, 13-40.

Angelo, Silvia/ Schlager, Christa/ Lunzer, Gertraud/ Bergmann, Nadja/ Mayrhuber, Christine (2003): Engendering Budgets -Problemaufriss für Österreich. In: Kurswechsel 1/2003, 26-36.

Appel, Margit/ Gubitzer, Luise/ Sauer, Birgit (2003): Zivilgesellschaft - ein Konzept für Frauen? Eine Einführung in den Band. In: Appel, Margit/ Gubitzer, Luise/ Sauer, Birgit (Hg.): Zivilgesellschaft - ein Konzept für Frauen? Wien: Peter Lang Verlag, 7-15.

Arnstein, Sherry (1967): A Ladder of Citizen Participation. In: Journal of the American Planning Association, Vol. 35, Nr. 4, 216-224.

Avritzer, Leonardo (o.J): Modes of Democratic Deliberation: theoretical remarks on participatory budgeting in Brazil. In: http://www.chs.ubc.ca/participat ory/docs/avritzer2.pdf, abgerufen am 4.5.2007 
Avritzer, Leonardo (2000): Civil Society, Public Space and Local Power: a study of the Participatory Budget in Belo Horizonte and Porto Alegre. In: http:// www.chs.ubc.ca/ participatory/docs/avritzer.pdf, abgerufen am 4.5.2007

Avritzer, Leonardo (2002): New Public Spheres in Brazil: Local Democracy and Deliberative Politics. In: http://www.democraciaparticipativa.org/English/Arqui vos/avritzer_newpbspheres.htm, abgerufen am 4. 5.2007

Avritzer, Leonardo/ Santos, Boaventura de Sousa (2003): Towards widening the democratic canon. In: http://eurozine.com/pdf/2003-11-03-santos-en.pdf, abgerufen am 5.5.2007

Baierle, Sérgio (2002): Transformation and empowerment through the Participatory Budget. International Workshop on Participatory Planning. Approaches for Local Governance, Bandung (Indonesia). In: http://www2.ids.ac.uk/logolink /resources/downloads/PPcase_stu dies/Brazil-CIDADE1.doc, abgerufen am 4.5. 2007

Baiocchi, Gianpaolo (1999): Participation, Activism and Politics: The Porto Alegre Experiment and Deliverative Democratic Theory. In: http://www.ssc.wis c.edu/ wright/ Baiocchi.PDF, abgerufen am 5.5.2007.

Baiocchi, Gianpaolo (2003): Participation, Activism, and Politics: The Porto Alegre Experiment. In: Fung, Archon/ Wright, Erik Olin (Hg.): Deepening Democracy. Institutional Innovations in Empowered Participatory Governance. The Real Utopias Project IV. London: Verso.

Bajohr, Stefan (2003): Grundriss Staatliche Finanzpolitik. Opladen: Leske \& Budrich.

Bakker, Isabella (1994): Introduction: Engendering Macro-economic Policy Reform in the Era of Global Restructuring and Adjustment. In: Bakker, Isabella (Hg.): The Strategic Silence. Gender and Economic Policy. London: Zed Books, 1-29.

Bakker, Isabella (2002): Fiscal Policy, Accountability and Voice: The Example of Gender Responsive Budget Initiatives. UNDP. In: http://hdr.undp.org/docs/ publications/background_pa-pers/2002/Bakker_2002.pdf, abgerufen am 2.3. 2007

Barber (1994): Starke Demokratie. Über die Teilhabe am Politischen. Hamburg: Rotbuch Verlag.

Beck (1986): Risikogesellschaft. Auf dem Weg in eine andere Moderne. Frankfurt am Main: Suhrkamp. 
Becker, Joachim (2001a): Der progressive erweiterte Staat: Zivilgesellschaft, Lokalstaat und partizipatives Budget in Porto Alegre. In: http://www.memo.unibremen.de/docs/m1 101.pdf, abgerufen am 4.5.2007

Becker, Joachim (2001b): Umkämpfte Grenzziehungen: die gesellschaftliche Reichweite der Demokratie. In: Kurswechsel 4/2001, 97-102.

Becker-Schmidt, Regina/ Bilden, Helga (1991): Impulse für die qualitative Sozialforschung aus der Frauenforschung. In: Flick, Uwe/ Kardorff, Ernst von/ Keupp, Heiner/ Rosenstiel, Lutz von/ Wolff, Stephan, Hrsg. (1991): Handbuch Qualitative Sozialforschung. Grundlagen, Konzepte, Methoden und Anwendungen. Psychologie Verlags Union, München, 23-30.

BEIGEWUM (2002): Frauen macht Budgets. Staatsfinanzen aus Geschlechterperspektive. Wien: Mandelbaum Verlag.

Benhabib, Seyla (1996): Towards a Deliberative Model of Democratic Legitimacy. In: In: Benhabib, Seyla (Hg.): Democracy and Difference. Contesting the Boundaries of the Political, Princeton: Princeton University Press, 67-94.

Benhabib, Seyla (1998): Models of Public Space: Hannah Arendt, the Liberal Tradition, and Jürgen Habermas. In: Landes, Joan B. (Hg.): Feminism, the Public and the Private, Oxford/New York: Oxford University Press, 65-99.

Bergmann, Nadja/ Gubitzer, Luise/ Klatzer, Elisabeth/ Klawatsch-Treitl, Eva/ Neumayr, Michaela (2004): Gender Budgeting. Handbuch zur Umsetzung geschlechtergerechter Budgetgestaltung. Wien: Remaprint.

Beveridge, Fiona/ Nott, Sue / Stephen, Kylie (2000): Mainstreaming and the engendering of policy-making: a means to an end? In: Journal of European Public Policy Vol.7, No. 3, 385-405.

Blanchard, Olivier (2000): Macroeconomics. 2nd Edition, New Jersey: PrenticeHall, Inc.

Blankart, Charles B. (2003): Öffentliche Finanzen in der Demokratie. 5. Auflage, München: Verlag Franz Vahlen.

Brangsch, Lutz (2003): Demokratie im Haushalt. Partizipative Haushaltspolitik als Einstieg in eine andere Politik. In: RLS Standpunkte 9/2003.

Breuss, Fritz (2002): Die Wirtschaftspolitische Architektur der WWU. In: WIFO Monatsberichte 9/2002, 581-607.

Brockhaus Enzyklopädie (1968) 17. Auflage, F.A. Brockhaus, Wiesbaden. 
Bröthaler, Johann/Bauer, Helfried/Schönbeck, Wilfried (2006): Österreichische Gemeinden im Netz der finanziellen Transfers: Steuerung, Förderung Belastung. Wien/New York: Springer.

Budlender, Debbie/ Elson, Diane/ Hewitt, Guy/ Mukhopadhyay, Tanni (2002): Gender Budgets Make Cents. Understanding gender responsive budgets. London: Commonwealth Secretariat.

Budlender, Debbie/ Hewitt, Guy (2002): Gender Budgets Make More Cents. Country Studies and Good Practice. London: Commonwealth Secretariat.

Budlender, Debbie (2004): Expectations versus Realities in Gender-responsive Budget Initiatives. In: http://www.gender-budgets.org/uploads/user-S/11281073 931Debbie_Budlender-_Expectations_vs._Realities_in_GRB_Initiatives.pdf, abgerufen am 10.7.2007.

Bundesministerium für Finanzen (BMF) (2002): Ist das österreichische Steuersystem tatsächlich 'geschlechtsneutral'? Ergebnis eines Lohn- und Einkommensteuer-Vergleichs Männer - Frauen. In: http://www.bmf.gv.at/Finanzministeriu $\mathrm{m} /$ GenderMainstreaming/gender.pdf, abgerufen am 10.7.2007.

Caiazza, Amy (2002): Does Women's Representation in Elected Office Lead to Women-Friendly Policy? In: http://www.iwpr.org/pdf/i910.pdf, abgerufen am 20.9.2007.

Cagatay, Nilufer/ Keklik, Mümtaz/ Lal, Radhika/ Lang, James (2000): Budgets as if people mattered: democratizing macroeconomic policies. SEPED Conference Paper, Nr.4. In: http://www.undp.org/seped/publications/budgets.pdf, abgerufen 2.3.2007.

Cagatay, Nilufer/ Ertürk Korkuk (2004): Gender and globalization: a macroeconomic perspective. International Labour Organization, Working Paper Nr. 19, Genf.

Cassel, Dieter/ Thieme, Jörg (2007): Stabilitätspolitik. In: Vahlens Kompendium der Wirtschaftstheorie und Wirtschaftspolitik, Band 2. 9. Auflage, München: Verlag Franz Vahlen, 435- 512.

Cohen, Jean L. (1996): Democracy, Difference, and the Right of Privacy. In: Benhabib, Seyla (Hg.): Democracy and Difference. Contesting the Boundaries of the Political, Princeton: Princeton University Press, 187-217.

Cohen, Joshua (1996): Procedure and Substance in Deliberative Democracy. In: Benhabib, Seyla (Hg.): Democracy and Difference. Contesting the Boundaries of the Political, Princeton: Princeton University Press, 95-119. 
Cornwall, Andrea/ Goetz Anne Marie (2005): Democratizing Democracy: Feminist Perspectives. In: Democratization, Vol. 12, No. 5, 783-800.

Demirovic, Alex (2001): Komplexität und Emanzipation. In Demirovic, Alex (Hg.): Kritische Gesellschaftstheorie und die Herausforderung der Systemtheorie Niklas Luhmans, Münster: Westfälische Dampfboot, 13-52.

Dettling, Warnfried (1974): Demokratisierung. Wege und Irrwege. Köln: Deutscher Instituts-Verlag.

Dewey, John (1927/1991): The public and its problems. Athens: Swallow Press/ Ohio University Press.

Einhaus, Arnd / Kitzmantel, Edith / Rainer, Anton (2006): Ist die Einkommensbesteuerung geschlechtsneutral? In: BMF Working Paper 2/2006.

Elias, Norbert (1970): Was ist Soziologie? München: Juventa Verlag.

Elson, Diane/ Cagatay, Nilufer/ Grown, Caren (1995): Introduction. In: World Development, Vol. 23, Nr. 11, 1827-1836.

Elson, Diane (1999): Gender Budget Initiative. Background Paper. London: Commonwealth Secretariat.

Elson, Diane (2002a): Gender Responsive Budget Initiatives: Some Key Dimensions and Practical Example. In: Gender Budgeting Initiatives. Strategies, Concepts and Experiences, Papers from the International Conference "Strengthening Economic and Financial Governance Through Gender Responsive Budgeting", 16.-18. Oktober 2001, Brüssel, 15-29.

Elson, Diane (2002b): Geschlechtergerechtigkeit durch Gender-Budgeting? Einige Aspekte und Beispiele aus der Praxis von Gender-Responsive-BudgetInitiativen, In: http://www.boell.de/downloads/gd/Einmischung2_ElsonYoung. pdf, abgerufen am 10.7.2007.

Elson, Diane (2004): Gender equality, public finance and globalization, Paper for Conference on Egalitarian Development in the Era of Globalization in Honor of Professor Keith Griffin, 22.-24. April 2004, University of Massachusetts Amherst.

Elson, Diane (2006): Gender Budgeting has a lot of potential to promote emancipatory policies - but this potential has not yet been realized. In: Klatzer, Elisabeth/ Neumayr, Michaela (Hg.): Gender Budgeting in Europa. Konferenzdokumentation, Kammer für Arbeiter und Angestellte für Wien, Wien, 96-98. 
Europäische Kommission (1998): 100 Begriffe aus der Gleichstellungspolitik. Glossar der Gleichstellung zwischen Frauen und Männern, Luxemburg.

Felderer, Bernhard/ Homburg, Stefan (2003): Makroökonomik und neue Markoökonomik. 8. Auflage, Berlin: Springer.

Ferber, Marianne A./ Nelson, Julie A. (Hg): Beyond Economic Man: Feminist Theory and Economics. Chicago: University of Chicago Press.

Fleischmann, Eduard (2002): Öffentliche Haushalte in Österreich im Überblick. In: Steger, Gerhard (Hg.): Öffentliche Haushalte in Österreich, Wien: Verlag Österreich, 7-26.

Fraser, Nancy (2001): Die halbierte Gerechtigkeit. Schlüsselbegriffe des postindustriellen Sozialstaats. Frankfurt am Main: Suhrkamp Verlag.

Fraser, Nancy (2003): Soziale Gerechtigkeit im Zeitalter der Identitätspolitik. Umverteilung, Anerkennung und Beteiligung. In: Fraser, Nancy/ Honneth, Axel: Umverteilung oder Anerkennung? Eine politisch-philosophische Kontroverse. Frankfurt am Main: Suhrkamp Verlag, 13-128.

Fraser, Nancy (2005): Mapping the Feminist Imagination: From Redistribution to Recognition to Representation. In: Constellations Vol. 12, No 3, 295-307.

Fung, Archon/ Wright, Erik Olin (2001): Deepening Democracy: Innovations in Empowered Participatory Governance. In: Politics \& Society, Vol. 29, Nr. 1, 541.

Gläser, Jochen/ Laudel Gerit (2006): Experteninterviews und qualitative Inhaltsanalyse als Instrumente rekonstruierender Untersuchungen. 2. Auflage, Wiesbaden: VS Verlag für Sozialwissenschaften

Graf, Gerhard (2005): Grundlagen der Finanzwirtschaft. 2. Auflage, Heidelberg: Physica-Verlag.

Grossekettler, Heinz (2007): Öffentliche Finanzen. In: Vahlens Kompendium der Wirtschaftstheorie und Wirtschaftspolitik, Band 1. 9. Auflage, München: Verlag Franz Vahlen, 561-721.

Gubitzer, Luise/ Klatzer, Elisabeth/ Neumayr, Michaela (2006): Gender Budgeting in der Bundesverwaltung. Pilotstudie am Beispiel ausgewählter Teile des Drogenbudgets. Unveröffentlichte Studie im Auftrag des Bundesministeriums für Gesundheit und Frauen, Wien. 
Hafner, Gustav (Red.)/ Bauer, Helfried (1995): Finanz- und Betriebswirtschaft der Gemeinden. Stichworte für die Praxis. Wien: Verein Kommunalwissenschaftliches Dokumentationszentrum.

Hansmeyer, Karl-Heinrich (1986): Ursachen des Wandels der Budgetpolitik. In: Häuser, Karl (Hg.): Budgetpolitik im Wandel. Berlin: Duncker \& Humblot, 1132.

Hewitt, Guy/ Mukhopadhyay, Tanni (2002): Promoting Gender Equality through Public Expenditure. In: Budlender, Debbie/ Elson, Diane/ Hewitt, Guy/ Mukhopadhyay, Tanni: Gender Budgets Make Cents. Understanding gender responsive budgets. London: Commonwealth Secretariat, 49-81.

Hill, Donna (2002): United Kingdom: A Focus on taxes and benefits. In: Budlender, Debbie/ Hewitt, Guy (2002): Gender Budgets Make More Cents. Country Studies and Good Practice. London: Commonwealth Secretariat, 171-192.

Himmelweit, Susan (2002): Making visible the hidden economy: the case for gender impact analysis of economic policy. In: Feminist Economics Vol. 8, Nr. 1, 49-70.

Hofbauer-Balmori, Helena (2003): Gender and Budgets. Overview Report, In: http://www.bridge.ids.ac.uk/reports/CEP-Budgets-report.pdf, abgerufen am 2.3. 2007

Holland-Cunz, Barbara (1998): Feministische Demokratietheorie. Thesen zu einem Projekt. Opladen: Leske \& Budrich.

Holland-Cunz, Barbara (1999): Gender Gap in der Demokratie - Geschlechterverhältnis und direkte Demokratie. In: Fechter, Mathias/ Wagner, Bernd (Hg.): Gesellschaftliche Perspektiven: Zeit, Demokratie, Natur. Jahrbuch der Hessischen Gesellschaft für Demokratie und Ökologie, Band 1. Essen: Klartextverlag, 76-90.

Holland-Cunz, Barbara (2001): Komplexität oder Schlichtheit: Wie soll sich die Demokratietheorie auf die neuen Herausforderungen einstellen? In: Femina Politica Jg. 10, Heft 2, 62-76.

Holland-Cunz, Barbara (2003): Die alte neue Frauenfrage. Frankfurt am Main: Surkamp Verlag.

Homann, Karl/ Suchanek, Andreas (2005): Ökonomik eine Einführung. 2.Auflage, Tübingen: Mohr Siebeck. 
Jauk, Vera (2007): Gender Budgeting - Beispiele aus Österreich. Unveröffentlichte Zusammenstellung im Zuge der Europäischen Fachkonferenz „Gender Budgeting: Die Verteilung macht's - Gleichstellung und soziale Gerechtigkeit durch geschlechtersensible Haushalte“, 4. und 5. Juni 2007 in Frankfurt/Main.

Jones, Kathleen B. (1990): Citizenship in a Woman-Friendly Polity. In: Signs, Vol. 15, No. 4, 781-812.

Kardam, Nüket/ Acuner, Selma (2003): National women's machineries: structures and spaces. In: Rai, Shirin M. (Hg.): Mainstreaming gender, democratizing the state? Institutional mechanisms for the advancement of women. Manchester: Manchester University Press, 96-113.

Klatzer, Elisabeth (2003): Geschlechtergerechtigkeit als Kernthema der Budget und Wirtschaftspolitik: Analyse der Theorie und Praxis von Engendering Budgets. Dissertation, Wirtschaftsuniversität Wien.

Klatzer, Elisabeth (2004): Geschlechtergerechte Budgetgestaltung - Gender Budgeting in Österreich. Überblick und Ausblick. In: Frauenabteilung der Stadt Wien (Hg.): Gender Budgeting 2004. Wege zur geschlechtergerechten Verteilung öffentlicher Güter und Leistungen, Wien, 13-34.

Keiser, Lael R./ Wilkins, Vicky M./ Meier, Kenneth J./ Holland Catherine (o.J.): Lipstick and Logarithms: Gender, Institutional Context, and Representative Bureaucracy. In: http://teep.tamu.edu/pubs/lipstick.pdf, abgerufen am 1.9.2007.

Koonings, Kees (2004): Strengthening citizenship in Brazil's democracy: Local participatory governance in Porto Alegre. In: Bulletin of Latin American Research, Vol. 23, No. 1, 79-99.

Kroll, Renate (Hg.) (2002): Metzler Lexikon Gender Studies - Geschlechterforschung. Ansätze - Personen - Grundbegriffe. Stuttgart: Verlag J.B. Metzler.

Kreisky, Eva/ Sauer, Birgit (1997): Heimlichkeit und Kanonisierung. Einführende Bemerkungen zur Begriffsbildung in der Politikwissenschaft. In: Kreisky, Eva/ Sauer, Birgit (Hg.): Das geheime Glossar der Politikwissenschaft. Geschlechterkritische Inspektion der Kategorien einer Disziplin, Frankfurt: Campus Verlag, 7-45.

Krüger, Marlis (1994): Methodologische und wissenschaftstheoretische Reflexion über eine feministische Soziologie und Sozialforschung. In: Diezinger, Angelika/ Kitzer, Hedwig/ Anker, Ingrid/ Odierna, Simone/ Haas, Erika/ Bingel, Irma, Hrsg. (1994): Erfahrung mit Methode. Kore Verlag, Freiburg, 69-84.

Kurswechsel-Reaktion (2003): Editorial. In: Kurswechsel 1/2003, 3-6. 
Lambertz, Günter (1984): Demokratie oder Eliteherrschaft? Sind die Bürger nur Statisten? Krefeld: la fleur-Verlag.

Lambertz Günter (1991): Bessere Wirtschaftspolitik durch weniger Demokratie? Hamburg S\&W Steuer- und Wirtschaftsverlag.

Lang, Sabine (1994): Politische Öffentlichkeit und Demokratie. Überlegungen zur Verschränkung von Androzentrismus und öffentlicher Teilhabe. In Biester, Elke/ Holland-Cunz, Barbara/ Sauer, Birgit (Hg.): Demokratie oder Androkratie? Theorie und Praxis demokratischer Herrschaft in der feministischen Diskussion. Frankfurt am Main: Campus Verlag, 201-226.

Lavan, Kezia (2006): Towards Gender-Sensitive Participatory Budgeting. PB Unit. In: http://www.participatorybudgeting.org.uk/Downloads/Towards\%20a\% 20gender\%20sensitive\%20PB\%20.pdf, abgerufen am 20.9.2007.

Leftwich, Adrian (2004): Thinking Politically: On the politics of Politics. In: Leftwich, Adrian (Hg.): What is Politics? The Activity and its Study. Cambridge: Polity Press, 1-22.

Leubolt, Bernhard (2003): Das Partizipative Budget. Demokratisierung der Wirtschaftspolitik in Porto Alegre. In: Kurswechsel 1/2003, 44-54.

Lister, Ruth (o.J): Citizenship and Gender. In: http://www.socsci.auc.dk/cost/ gender/Working papers/lister.pdf, abgerufen am 1.9.2007.

Lister, Ruth (1997): Engendering Citizenship, Work and Care. FREIA - Feminist Research Centre in Aalborg Paper, Aalborg.

Lister, Ruth/ Hobson, Barbara (2001): Keyword: Citizenship. In: http://portal. unesco.org/shs/fr/file_download.php/995815fd94412ec1556af27aa39e71b8citiz enship.pdf, abgerufen am 1.9.2007.

Mankiw, Gregory (2000): Macroeconomics. 4th Edition, New York: Worth Publishers.

Massing, Peter/ Breit, Gotthard (Hg.): Demokratietheorien: Von der Antike bis zur Gegenwart. Texte und Interpretationshilfen. Schwalbach: Wochenschau Verlag.

Matzinger, Anton (2002): Finanzausgleich. In: Steger, Gerhard (Hg.): Öffentliche Haushalte in Österreich, Wien: Verlag Österreich, 51-100. 
Mayrhuber, Christine (2006): Kurzüberblick über Gender Budgeting Initiativen und Projekte in Österreich. In: Klatzer, Elisabeth/ Neumayer, Michaela, (Hg.): Gender Budgeting in Europa. Konferenzdokumentation, Kammer für Arbeiter und Angestellte für Wien, Wien, 23-36.

Mayring, Philipp (2000). Qualitative Inhaltsanalyse. Forum Qualitative Sozialforschung/ Forum: Qualitative Social Research, Vol. 1, No. 2. In: http:/qualitati ve-research.net/fqs/fqs-d/2-00inhalt-d.htm, abgerufen am 9.8.2007.

Mayring, Philipp (2003): Qualitative Inhaltsanalyse. Grundlagen und Techniken. 8. Auflage, Weinheim und Basel: Beltz Verlag.

Mayring, Philipp (2005): Neuere Entwicklungen in der qualitativen Forschung und der Qualitativen Inhaltsanalyse. In: Mayring, Philipp/ Gläser-Zikuda, Michaela (Hg.): Die Praxis der Qualitativen Inhaltsanalyse Weinheim: Beltz, 719.

Merten, Klaus (1983): Inhaltsanalyse. Einführung in Theorie, Methode und Praxis. Opladen: Westdeutscher Verlag.

Michalitsch, Gabriele (2003): Wer, wie viel, für was? Gender Budgeting und öffentliche Finanzen. In: Dackweiler, Regina-Maria/ Hornung, Ursula (Hg.): frauen - macht - geld. Münster: Verlag Westfälisches Dampfboot.

Michalitsch, Gabriele (2005): Kein Haushalt ist geschlechtsneutral. In: Gender Budgeting in NRW- Dem Ziel näher kommen! Dokumentation der Veranstaltung vom 18. Februar 2005 im Landtag Nordrhein-Westfalen.

Michalitsch, Gabriele (2006): Geschlechterpolitische Defizite: Staatsfinanzen und Gender Budgeting. In: Lichtenecker, Ruberta/ Salmhofer, Gudrun (Hg.): Gender Budgeting. Innsbruck: Studienverlag, 13-28.

Miños, Daniel Chavez (2002): Porto Alegre, Brazil: A new, sustainable and replicable model of participatory and democratic governance? In: http://www.tni.or g/archives/chavez/ ortoalegre.pdf, abgerufen am 5.5.2007.

Neck, Reinhard Nowotny, Ewald/ Winckler, Georg (2001): Grundzüge der Wirtschaftspolitik in Österreich. 3. Auflage, Wien: Manz.

Neumark, Fritz (1952a): Theorie und Praxis der Budgetgestaltung. In: Gerloff, Wilhelm/ Neumark, Fritz (Hg.): Handbuch der Finanzwissenschaft. 1. Band. Tübingen: J.C.B Mohr, 554-605. 
Neumark, Fritz (1952b): Grundsätze und Arten der Haushaltsführung und Finanzbedarfsdeckung. In: Gerloff, Wilhelm/ Neumark, Fritz (Hg.): Handbuch der Finanzwissenschaft. 1. Band. Tübingen: J.C.B Mohr, 606-669.

North, Douglas (1990): Institutions, Institutional Change and Economic Performance. Cambridge: Cambrige University Press.

Norton, Andy/ Elson, Diane (2002): What's behind the budget? Politics, rights and accountability in the budget process, Overseas Development Institute. In: ht tp://www.odi.org.uk/pppg /publications/books/budget.pdf abgerufen am 2.3. 2007

Novy, Andreas (2003): Eine neue Dynamik der Demokratisierung in Gang setzen. In: Kurswechsel 1/2003, 7-13.

Novy, Andreas/ Leubolt, Bernhard (2004): Das Partizipative Budget in Porto Alegre: Die Dialektik von staatlichen und nicht-staatlichen Formen sozialer Innovation. In: SRE-Discussion Papers, Nr. 2004/03.

Nowotny, Ewald (1999): Der öffentliche Sektor. Eine Einführung in die Finanzwissenschaft. 4., neubearbeitete und erweiterte Auflage, Berlin/Heidelberg: Springer-Verlag.

O'Connell, Helen (2007): Feminist Democracy? Interview. In: Development, Vol. 50, No.1, 14-16.

Osmani, Siddiq R. (2002): Expanding Voice and Accountability through the Budgetary Process. In: Journal of Human Development, Vol. 3, Nr. 2, 231-250.

Part, Peter (1998): Der Stabilitäts und Wachstumspakt. In: Das öffentliche Haushaltswesen in Österreich, Ausg. 1-2/1998 (Jg. 39), 38-46.

Part, Peter (2002): Öffentliche Haushalte in den EU-Staaten. In: Steger, Gerhard (Hg.): Öffentliche Haushalte in Österreich, Wien: Verlag Österreich, 27-50.

Pasterniak, Angelika (2006): Budgetregeln und die Qualität der öffentlichen Finanzen. Europäische Perspektiven und österreichische Praxis. Wiesbaden: Deutscher Universitäts-Verlag.

Pateman, Carole (2004): Democratizing Citizenship: Some Advantages of a Basic Income. In: Politics and Society, Vol. 32, No.1.

Phillips, Anne (1993): Democracy and difference. Pennsylvania: The Pennsylvania State University Press. 
Phillips, Anne (1994): Must Feminists Give Up on Liberal Democracy? In: Held, David (Hg.): Prospects for Democracy, Cambridge/Oxford: Polity Press, 93-111.

Phillips, Anne (1995): Geschlecht und Demokratie. Hamburg: Rotbuch Verlag.

Phillips, Anne (1996): Dealing with Difference: A Politics of Ideas, or a Politics of Presence? In: Seyla Benhabib (Hg.): Democracy and Difference. Contesting the Boundaries of the Political. Princeton: Princeton University Press, 139-152.

Phillips, Anne (1999): Which equality matter? Cambridge: Polity Press.

Phillips, Anne (2006): Dealing with difference: A politics of ideas or a politics of presence? In: Goodin, Robert/ Pettit, Philip, (Hg.): Contemporary political philosophy. An anthology. Oxford: Blackwell Publishing Ltd, 2. Auflage, 171181.

Raes, Florence (2006): What can we expect from gender sensitive budgets? Strategies in Brazil and in Chile in a comparative perspective. In: http://www.eu rosur.org/wide/home.htm, abgerufen am 4.5.2007.

Rai, Shirin M. (2003) (Hg.): Mainstreaming gender, democratizing the state? Institutional mechanisms for the advancement of women. Manchester: Manchester University Press.

Rai, Shirin M. (2005): Equal participation of women and men in decision-making processes, with particular emphasis on political participation and leadership, Background paper for the Expert Group Meeting on „Equal participation of women and men in decision- making processes, with particular emphasis on political participation and leadership" 24-27 Oktober 2005, Addis Ababa, Ethiopia. In: http://www.un.org/womenwatch/daw/egm/eql-men/docs/B P.1\%20Back ground\%20Paper.pdf, abgerufen am 1.9.2007.

Rechnungsabschluss (2006): Gender Budgeting. Wien, 293-316.

Reichard, Christoph (1994): New Public Management. In: Hofmann, Michael, Al-Ani, Ayad (Hg.): Neue Entwicklungen im Management. Heidelberg: Physica, 135-164.

Reuter, Norbert (1998): Institutionen in der Ökonomik - zum Verhältnis von „alter" und „neuer" Institutionenökonomik. In: Elsner, Wolfram/ Engelhardt, Werner Wilhelm, Glastetter, Werner (Hg.): Ökonomie in gesellschaftlicher Verantwortung. Sozialökonomik und Gesellschaftsreform heute. Festschrift zum 65. Geburtstag von Siegfried Katterle. Berlin: Duncker \& Humblot, 61-91. 
Ribot, Jesse C. (2007): Representation, Citizenship and the Public Domain in Democratic Decentralization. In: Development, Vol. 50, No.1, 43-49.

Rossmann, Bruno/ Schlager, Christa (2006): Der öffentliche Sektor in Österreich - Teil II. Budgetkreislauf, Bundesbudget, Finanzausgleich und EU-Haushalt. Skriptum des Österreichischen Gewerkschaftsbundes und der Kammer für Arbeiter und Angestellte.

Samuelson, Paul/ Nordhaus, William (1998): Volkswirtschaftslehre: Übersetzung der 15. Auflage, Wien: Überreuter.

Santos, Boaventura de Sousa (1998): Participatory budgeting in Porto Alegre: Toward a redistributive democracy. In: Politics \& Society, Vol. 26, Nr. 4, (http://www.ssc.wisc.edu/ wright/santosweb.html), abgerufen am 4.3.2007.

Santos, Boaventura de Sousa (2005): Two Democracies, two Legalities: Participatory Budgeting in Porto Alegre, Brazil. In: Santos, Boaventura de Sousa/ Rodríguez-Garavito, César (Hg.): Law and Globalization from Below. Towards a Cosmopolitan Legality. Cambridge: Cambridge University Press, 310-338.

Sartori, Giovanni (1992): Demokratietheorie. Darmstadt: Wissenschaftliche Buchgesellschaft.

Sauer, Birgit (2001): Die Asche des Souveräns. Staat und Demokratie in der Geschlechterdebatte. Frankfurt/New York: Campus Verlag.

Sauer, Birgit (2003a): Staat, Demokratie und Geschlecht - aktuelle Debatten. In: http://www.fu-berlin.de/gpo/pdf/birgit_sauer/birgit_sauer.pdf, abgerufen am 20. 9.2007 .

Sauer, Birgit (2003b): Zivilgesellschaft versus Staat? Geschlechterkritische Anmerkungen $\mathrm{zu}$ einer problematischen Dichotomie. In: Appel, Margit/ Gubitzer, Luise/ Sauer, Birgit (Hg.): Zivilgesellschaft - ein Konzept für Frauen? Wien: Peter Lang Verlag, 117-136.

Sawer, Marian (2002): Australia: The mandarin approach to gender budgets. In: Budlender, Debbie/ Hewitt, Guy (2002): Gender Budgets Make More Cents. Country Studies and Good Practice. London: Commonwealth Secretariat , 4364.

Schedler, Kuno/ Proeller, Isabella (2006): New Public Management. 3. Auflage, Bern/Stuttgart/Wien: Haupt Verlag.

Scherz, Viktor (2001): Demokratisierung der Wirtschaftspolitik. In: Kurswechsel 4/2001, 79-88. 
Schlager, Christa (2006): Gender Budgeting - ein Instrument zur Förderung emanzipatorischer Politik in Europa? In: Klatzer, Elisabeth/ Neumayer, Michaela, (Hg.): Gender Budgeting in Europa. Konferenzdokumentation, Kammer für Arbeiter und Angestellte für Wien, Wien, 98-100.

Schmidt, Manfred G. (2000): Demokratietheorien. Eine Einführung. 3., überarbeitete und erweiterte Auflage, Wiesbaden: VS Verlag für Sozialwissenschaften.

Schneider, Aaron/ Goldfrank, Ben (2002): Budgets and ballots in Brazil: participatory budgeting from the city to the state. IDS Working Paper 149. Brighton: Institute of Development Studies.

Schratzenstaller, Margit (2005): Neuer Finanzausgleich und Stabilitätspakt keine grundlegenden Änderungen. In: WIFO-Monatsberichte 1/2005, 49-60.

Schratzenstaller, Margit/ Mayrhuber, Christine/ Neumayer, Michaela/ Buchinger, Birgit/ Gschwandtner, Ulrike (2006): Gender-Budget-Analyse für Oberösterreich, Studie des Österreichischen Instituts für Wirtschaftsforschung und Solution im Auftrag des Amtes der Oberösterreichischen Landesregierung.

Schubert, Klaus/ Martina Klein (2006): Das Politiklexikon. In: www.bpb.de/lex ika

Schuberth, Helene (2006): Fiskale Strategien auf EU-Ebene - Implikationen für Gender Budgeting. In: Lichtenecker, Ruberta/ Salmhofer, Gudrun (Hg.): Gender Budgeting. Innsbruck: Studienverlag, 49-60.

Schugurensky, Daniel. Participatory Budget: A tool for democratizing democracy. Toronto Metro Hall, April 29, 2004. In: http://fcis.oise.utoronto.ca/ daniel_ sc/lclp/PB_DS_talk_04-04.pdf, abgerufen am 4.5.2007.

Schunter-Kleemann, Susanne (2001): Gender Mainstreaming - Neoliberale Horizonte eines neuen Gleichstellungs-Konzepts. In: Kurswechsel, 3/2001, 16-26.

Schunter-Kleemann, Susanne (2006): Gender Mainstreaming und die Ziele der Neuen Frauenbewegung(en) - Uneindeutigkeiten und der Verlust des Politischen. In: Gubitzer, Luise/ Schunter-Kleemann, Susanne (Hg.): Gender Mainstreaming - Durchbruch der Frauenpolitik oder deren Ende? Kritische Reflexionen einer weltweiten Strategie. Wien: Peter Lang Verlag, 39-67.

Seibel, Wolfgang (1997): Historische Analyse und politikwissenschaftliche Institutionenforschung. In: Benz, Arthur/ Weibel Wolfgang (Hg.): Theorieentwicklung in der Politikwissenschaft - eine Zwischenbilanz. Baden-Baden: Nomos, 357-376. 
Sharp, Rhonda/ Broomhill, Ray (2002): Budgeting for Equality: The Australian Experience. In: Feminist Economics Vol. 8, Nr. 1, 25.47.

Sharp, Rhonda (2003): Budgeting for equity: Gender budget initiatives within a framework of performance oriented budgeting. New York: United Nations Development Fund for Women (UNIFEM).

Sharp, Rhonda (2007): Financing for gender equality and the empowerment of women. In: United Nations, Written statement für die Commission on the Status of Women Fifty-first session, 26.2.-9.3.2007, New York.

Siegelkow, Rainer (1975): Wirtschaftsdemokratie. In: Studiengruppe Partizipationsforschung (Hg.): Partizipation - Demokratisierung - Mitbestimmung. Problemstellung und Literatur in Politik, Wirtschaft, Bildung und Wissenschaft. Eine Einführung. Opladen: Westdeutscher Verlag, 118-137.

Spehr, Christoph (2003): Gleicher als andere. Eine Grundlegung der freien Kooperation (Reihe: Texte/Rosa-Luxemburg-Stiftung; Bd. 9) Karl Dietz Verlag, Berlin.

Staender, Klaus (2004): Lexikon der öffentlichen Finanzwirtschaft. 6. Auflage, Heidelberg: C. F. Müller.

Sturm, Gabriele (1994): Wie forschen Frauen? Überlegungen zur Entscheidung für qualitatives oder quantifizierendes Vorgehen. In: Diezinger, Angelika/ Kitzer, Hedwig/ Anker, Ingrid/ Odierna, Simone/ Haas, Erika/ Bingel, Irma, Hrsg. (1994): Erfahrung mit Methode. Kore Verlag, Freiburg, 85-104.

Squires, Judith (1999): Gender in Political Theory. Cambridge: Polity Press.

Sugiyama, Natasha Borges (2003): Democratizing the Budget: Gendered Budget Analysis in Latin America, Paper prepared for the 2003 meeting of the Latin American Studies Association, Dallas. In http://lasa.international.pitt.edu/Lasa 2003/SugiyamaNatasha.pdf, abgerufen am 4.9.2007.

Taylor Viviene (2007): Recasting Power and Transforming Governance: A feminist perspective from the South. In: Development, Vol. 50, No.1, 28-35.

Vargas-Valente, Virginia (2002): Municipal Budgets and Democratic Governance in the Andean Region. In: Gender Budgeting Initiatives. Strategies, Concepts and Experiences, Papers from the International Conference "Strengthening Economic and Financial Governance Through Gender Responsive Budgeting", 16.-18. Oktober 2001, Brüssel, 101-112. 
Verba, Sidney/ Nie, Norman/ Kim, Jae-On (1978): Participation and Political Equality. A Seven-Nation Comparison. Cambridge: Cambridge University Press.

Vickers, Jill (2006): What Makes Some Democracies More 'Women-Friendly'? In: http://www.cpsa-acsp.ca/papers-2006/Vickers.pdf, angerufen am 20.9.2007.

Voranschlag (2006): Implementierung des Gender Budgeting in Wien. Wien, 257-276.

Walby, Sylvia (2005): Gender Mainstreaming Gender Mainstreaming: Productive Tensions in Theory and Practice. In: Social Politics. Vol. 12, No. 3, 321343.

Wampler, Brian (2000): A Guide to Participatory Budgeting. In: http://www. internationalbudget.org/cdrom/papers/systems/ParticipatoryBudgets/Wampler.p df, abgerufen am 5.5.2007.

Wiesner, Herbert (1986): Öffentliche Finanzwirtschaft I. Haushaltsrecht, 8. völlig neubearbeitete Auflage, Heidelberg: R.v.Decker's Verlag.

Wiesner, Herbert/ Leibinger, Bodo/ Müller, Reinhard (2004): Öffentliche Finanzwirtschaft. 11. Auflage, Heidelberg: v. Decker.

Winckler, Georg (1997): Geldwirtschaftlicher Sektor (Finanzsektor), In: Nowotny, Ewald/ Winckler, Georg (Hg.): Grundzüge der Wirtschaftspolitik Österreichs. 2. Auflage, Wien: Manz.

Wisniewski, Roswitha/ Kunst, Hermann (Hg.) (1988): Handbuch für Frauenfragen. Zur Stellung der Frau in der Gegenwart. Informationen - Analysen Anregungen. Stuttgart: Bonn Aktuell Verlag.

Young, Iris Marion (1990): Justice and the Politics of Difference. Princeton: Princeton University Press.

Young, Iris Marion (1993): Das politische Gemeinwesen und die Gruppendifferenz. Eine Kritik am Ideal des universalen Staatsbürgerstatus. In: Nagl-Docekal, Herta/ Pauer-Studer, Herlinde, (Hg.): Jenseits der Geschlechtermoral. Beiträge zu feministischen Ethik. Frankfurt am Main: Fischer Taschenbuch Verlag, 267-304.

Young, Iris Marion (1996): Communication and the Other: Beyond Deliberative Democracy. In: Benhabib, Seyla (Hg.): Democracy and Difference. Contesting the Boundaries of the Political, Princeton: Princeton University Press, 120-135. 
Young, Iris Marion (2000): Inclusion and Democracy. Oxford: University Press.

Zimmermann, Horst/ Henke, Klaus-Dirk (2001): Finanzwissenschaft. 8. Auflage, Verlag München: Franz Vahlen.

\section{Rechtsquellen und Dokumente}

Beijing Platform for Action der 4. Weltfrauenkonferenz-Empfehlung http:// www.un.org/women watch/daw/beijing/platform/plat2.htm

Bundesministerium für Finanzen, Budgetpolitik www.bmf.gv.at/Budget/Budget politik/_start. htm

Bundes-Verfassungsgesetz (B-VG) http://www.parlinkom.gv.at/PA/RG/Rechts grundlagen\%20und\%20Gesetze_Portal.shtml

COE Gender Budgeting-Endbericht http://www.coe.int/T/E/Human_Rights/Equ ality/PDF_EG-S-GB(2004)RAPFIN_E.pdf

Communiqué der Konferenz „Gender Responsive Budgeting: a Global Vision to Strengthen Economic and Financial Governance" http://www.gender-budgets. org/content/view/195/154/

Rechnungshof Leitbild und Strategiepapier http://www.rechnungshof.gv.at/uplo ads/media/Leitbild_02.pdf und http://www.rechnungshof.gv.at/uploads/media/St rategie_01.pdf

Wiener Stadtverfassung (WStV) http://www.magwien.gv.at/recht/landesrechtwien/rechtsvor schriften/pdf/v0010000.pdf

Wiener Gleichbehandlungsgesetz (W-GBG) http://www.magwien.gv.at/recht/la ndesrecht-wien/rechtsvorschriften/pdf/d4000000.pdf

\section{Websites}

BEIGEWUM http://www.beigewum.at

CIDADE http://www.ongcidade.org/

Projektstelle Gender Mainstreaming http://www.wien.gv.at/menschen/genderma instreaming 
Watchgroup. Gender \& Öffentliche Finanzen http://www.beigewum.at/TCgi/TC gi.cgi?tar- get=home\&P_Kat=10

Women's Budget Group http://www.wbg.org.uk/ 


\section{Forschungsergebnisse der Wirtschaftsuniversität Wlen}

Herausgeber: Wirtschaftsuniversität Wien vertreten durch a.o. Univ. Prof. Dr. Barbara Sporn

Band 1 Stefan Felder: Frequenzallokation in der Telekommunikation. Ökonomische Analyse der Vergabe von Frequenzen unter besonderer Berücksichtigung der UMTS-Auktionen. 2004.

Band 2 Thomas Haller: Marketing im liberalisierten Strommarkt. Kommunikation und Produktplanung im Privatkundenmarkt. 2005.

Band 3 Alexander Stremitzer: Agency Theory: Methodology, Analysis. A Structured Approach to Writing Contracts. 2005.

Band 4 Günther Sedlacek: Analyse der Studiendauer und des Studienabbruch-Risikos. Unter Verwendung der statistischen Methoden der Ereignisanalyse. 2004.

Band 5 Monika Knassmüller: Unternehmensleitbilder im Vergleich. Sinn- und Bedeutungsrahmen deutschsprachiger Unternehmensleitbilder - Versuch einer empirischen (Re-)Konstruktion. 2005.

Band 6 Matthias Fink: Erfolgsfaktor Selbstverpflichtung bei vertrauensbasierten Kooperationen. Mit einem empirischen Befund. 2005.

Band 7 Michael Gerhard Kraft: Ökonomie zwischen Wissenschaft und Ethik. Eine dogmenhistorische Untersuchung von Léon M.E. Walras bis Milton Friedman. 2005.

Band 8 Ingrid Zechmeister: Mental Health Care Financing in the Process of Change. Challenges and Approaches for Austria. 2005.

Band 9 Sarah Meisenberger: Strukturierte Organisationen und Wissen. 2005.

Band 10 Anne-Katrin Neyer: Multinational teams in the European Commission and the European Parliament. 2005.

Band 11 Birgit Trukeschitz: Im Dienst Sozialer Dienste. Ökonomische Analyse der Beschäftigung in sozialen Dienstleistungseinrichtungen des Nonprofit Sektors. 2006

Band 12 Marcus Kölling: Interkulturelles Wissensmanagement. Deutschland Ost und West. 2006.

Band 13 Ulrich Berger: The Economics of Two-way Interconnection. 2006.

Band 14 Susanne Guth: Interoperability of DRM Systems. Exchanging and Processing XML-based Rights Expressions. 2006.

Band 15 Bernhard Klement: Ökonomische Kriterien und Anreizmechanismen für eine effiziente Förderung von industrieller Forschung und Innovation. Mit einer empirischen Quantifizierung der Hebeleffekte von F\&E-Förderinstrumenten in Österreich. 2006.

Band 16 Markus Imgrund: Wege aus der Insolvenz. Eine Analyse der Fortführung und Sanierung insolventer Klein- und Mittelbetriebe unter besonderer Berücksichtigung des Konfigurationsansatzes. 2007.

Band 17 Nicolas Knotzer: Product Recommendations in E-Commerce Retailing Applications. 2008.

Band 18 Astrid Dickinger: Perceived Quality of Mobile Services. A Segment-Specific Analysis. 2007.

Band 19 Nadine Wiedermann-Ondrej: Hybride Finanzierungsinstrumente in der nationalen und internationalen Besteuerung der USA. 2008.

Band 20 Helmut Sorger: Entscheidungsorientiertes Risikomanagement in der Industrieunternehmung. 2008.

Band 21 Martin Rietsch: Messung und Analyse des ökonomischen Wechselkursrisikos aus Unternehmenssicht: Ein stochastischer Simulationsansatz. 2008. 
Band 22 Hans Christian Mantler: Makroökonomische Effizienz des Finanzsektors. Herleitung eines theoretischen Modells und Schätzung der Wachstumsimplikationen für die Marktwirtschaften und Transformationsökonomien Europas. 2008.

Band 23 Youri Tacoun: La théorie de la valeur de Christian von Ehrenfels. 2008.

Band 24 Monika Koller: Longitudinale Betrachtung der Kognitiven Dissonanz. Eine Tagebuchstudie zur Reiseentscheidung. 2008.

Band 25 Marcus Scheiblecker: The Austrian Business Cycle in the European Context. 2008.

Band 26 Aida Numic: Multinational Teams in European and American Companies. 2008.

Band 27 Ulrike Bauernfeind: User Satisfaction with Personalised Internet Applications. 2008.

Band 28 Reinhold Schodl: Systematische Analyse und Bewertung komplexer Supply Chain Prozesse bei dynamischer Festlegung des Auftragsentkopplungspunkts. 2008.

Band 29 Bianca Gusenbauer: Öffentlich-private Finanzierung von Infrastruktur in Entwicklungsländern und deren Beitrag zur Armutsreduktion. Fallstudien in Vietnam und auf den Philippinen. 2009.

Band 30 Elisabeth Salomon: Hybrides Management in sino-österreichischen Joint Ventures in China aus österreichischer Perspektive. 2009.

Band 31 Katharina Mader: Gender Budgeting: Ein emanzipatorisches, finanzpolitisches und demokratiepolitisches Instrument. 2009.

www.peterlang.de 
Katharina Mader - 978-3-631-75378-1

Downloaded from PubFactory at 01/11/2019 05:43:12AM

via free access 
Katharina Mader - 978-3-631-75378-1

Downloaded from PubFactory at 01/11/2019 05:43:12AM

via free access 